\title{
Relationship between seismic $P$-wave velocity and the composition of anhydrous igneous and meta-igneous rocks
}

\author{
M. D. Behn \\ MIT/WHOI Joint Program, Woods Hole Oceanographic Institution, Woods Hole, Massachusetts 02543, USA \\ Now at Department of Terrestrial Magnetism, Carnegie Institution of Washington, Washington, D.C. 20015, USA. \\ (behn@dtm.ciw.edu)
}

\section{P. B. Kelemen \\ Department of Geology and Geophysics, Woods Hole Oceanographic Institution, Woods Hole, Massachusetts 02543, USA (pkelemen@whoi.edu)}

[1] This study presents a new approach to quantitatively assess the relationship between the composition and seismic P-wave velocity of anhydrous igneous and meta-igneous rocks. We perform thermodynamic calculations of the equilibrating phase assemblages predicted for all igneous composition space at various pressure and temperature conditions. Seismic velocities for each assemblage are then estimated from mixing theory using laboratory measurements of the elastic parameters for pure mineral phases. The resultant velocities are used to derive a direct relationship between $V_{p}$ and major element composition valid to $\pm 0.13 \mathrm{~km} / \mathrm{s}$ for pressure and temperature conditions along a normal crustal geotherm in the depth range of $5-50 \mathrm{~km}$ and equilibration pressures $\leq 12 \mathrm{kbar}$. Finally, we use the calculated velocities to invert for major element chemistry as a function of P-wave velocity assuming only the in situ temperature and pressure conditions are known. Compiling typical velocity-depth profiles for the middle and lower continental and oceanic crust, we calculate compositional bounds for each of these geologic environments. We find that the acceptable compositional range for the middle $(15-30 \mathrm{~km})$ and lower continental $(\geq 35$ $\mathrm{km}$ ) crust is broad, ranging from basaltic to dacitic compositions, and conclude that P-wave velocity measurements alone are insufficient to provide fundamental constraints on the composition of the middle and lower continental crust. However, because major oxides are correlated in igneous rocks, joint constraints on $V_{p}$ and individual oxides can narrow the range of acceptable crustal compositions. In the case of the lower oceanic crust $(\geq 2 \mathrm{~km})$, observed velocities are $0.2-0.3 \mathrm{~km} / \mathrm{s}$ lower than velocities calculated based on the average bulk composition of gabbros in drill cores and exposed ophiolite sequences. We attribute this discrepancy to a combination of residual porosity at crustal depths less than $\sim 10 \mathrm{~km}$ and hydrous alteration phases in the lower crust, and suggest caution when inferring mantle melting parameters from observed velocities in the lower oceanic crust.

Components: 16,700 words, 14 figures, 12 tables, 1 dataset.

Keywords: Continental crust; oceanic crust; seismic P-wave velocity; igneous rocks; composition.

Index Terms: 1020 Geochemistry: Composition of the crust; 7205 Seismology: Continental crust (1242); 7220 Seismology: Oceanic crust.

Received 19 June 2002; Revised 14 November 2002; Accepted 10 January 2003; Published 3 May 2003.

Behn, M. D., and P. B. Kelemen, Relationship between seismic P-wave velocity and the composition of anhydrous igneous and meta-igneous rocks, Geochem. Geophys. Geosyst., 4(5), 1041, doi:10.1029/2002GC000393, 2003. 


\section{Introduction}

[2] Knowledge of the composition of the middle $(15-30 \mathrm{~km})$ and lower $(\geq 35 \mathrm{~km})$ continental crust and the lower oceanic ( $\geq 2 \mathrm{~km}$ ) crust is critical to our understanding of crustal formation and evolution. The composition of the crust also affects crustal rheology and plays an important role in controlling active tectonic processes in continental and oceanic environments. However, to date the composition of the middle and lower crust remains poorly constrained. Unlike the upper crust, which is easily accessible to geologic sampling, direct sampling of the middle and lower crust is limited to xenoliths, high-grade metamorphic terranes, rare exposures of high pressure igneous assemblages, and, in the case of oceanic crust, ophiolites. Although these samples have provided valuable insights into crustal composition, their heterogeneity and possible sampling bias make it difficult to assess how representative they are of the overall composition of the middle and lower crust.

[3] An alternate approach to studying middle and lower crustal composition involves seismic measurements, which allow large sections of the crust to be characterized in situ. Unfortunately, this method has been limited by the difficulty in determining rock types from estimates of average seismic velocity. One method that is frequently used to extrapolate composition from seismic data is forward modeling of seismic velocities for rocks with known seismic properties [e.g., Pakiser and Robinson, 1966; Smithson, 1978; Holbrook et al., 1992; Christensen and Mooney, 1995; Rudnick and Fountain, 1995]. In this approach, the elastic properties of a wide range of crustal compositions are first measured in the laboratory at different temperatures and pressures (e.g., Birch [1960, 1961]; Christensen [1965] and numerous studies thereafter). These results are then extrapolated to geologic conditions and compared with seismic refraction data to determine which rock types are consistent with the observed seismic data. While this method can be used to qualitatively assess the composition of the middle and lower crust, forward modeling cannot quantitatively evaluate the full range of compositions that are consistent with a specific set of seismic observations.

[4] Miller and Christensen [1994] and Kern et al. [1996] conducted early attempts to directly relate P-wave velocity, $V_{p}$, to major element content in middle and lower crustal rocks from the Kohistan accreted arc terrain and the North China craton. Following a similar approach, Kelemen and Holbrook [1995] compiled laboratory data on igneous and meta-igneous rocks from a wide range of geologic environments, and used multiple linear regression to relate $V_{p}$ to $\mathrm{SiO}_{2}$ and $\mathrm{MgO}$. The utility of the resulting empirical relationships, however, are limited by a number of factors. First, the samples for which both $V_{p}$ and compositional data are available do not encompass the full spectrum of compositions that may be present in the middle and lower crust. Second, under certain conditions laboratory measurements are hampered by microcracks and secondary alteration that may not be present in situ. These effects are particularly problematic in xenoliths, where grain boundary alteration during entrainment can significantly alter the physical properties of the sample [Rudnick and Jackson, 1995; Gao et al., 2000]. Finally, the pressure and temperature conditions at which a bulk composition equilibrates will govern its crystallizing mineral assemblage. Thus, for any single bulk composition, a range of seismic velocities will be predicted as a function of the equilibrium conditions [Sobolev and Babeyko, 1994]. The presence of garnet is of particular importance because its high seismic velocity implies that even in small quantities it can significantly increase the overall seismic velocity of a crystallizing assemblage. Because Kelemen and Holbrook [1995] were interested in studying igneous crust outside the garnet stability field, they eliminated samples containing garnet from their analysis. However, a comprehensive estimate of the composition of the middle and lower crust from seismic data must incorporate garnet and other high pressure phases.

[5] Sobolev and Babeyko [1994] addressed the importance of high pressure phases on seismic velocity by calculating equilibrium mineral assemblages for 9 representative igneous bulk 
compositions over a wide range of pressure and temperature conditions. From the equilibrium mineral assemblages they estimated seismic velocity for each composition using the method of Sobolev and Babeyko [1989]. Based on these results, Sobolev and Babeyko [1994] found that seismic velocities were most sensitive to $\mathrm{SiO}_{2}$ content and showed that felsic, intermediate, and mafic rocks could be broadly distinguished based on their $V_{p}$ to $V_{p} / V_{s}$ ratios. Similar methods have been used to examine hydrous rocks from the Kola borehole [Babeyko et al., 1994], anhydrous mantle xenoliths [Sobolev et al., 1996, 1997], and to construct mineralogical and seismic models for the Martian crust [Babeyko and Zharkov, 2000]. However, none of these studies have attempted to invert bulk composition directly from $V_{p}$.

[6] In this study, we expand on the petrophysical modeling of Sobolev and Babeyko [1994] to quantitatively assess the relationship between composition and P-wave velocity in anhydrous igneous and meta-igneous rocks. Specifically, we assess the full range of igneous and meta-igneous compositions that are consistent with a particular P-wave velocity, assuming that only the in situ temperature and pressure conditions are known. We perform thermodynamic calculations to determine the crystallizing mineral assemblages at various equilibrium conditions for all igneous composition space. Pwave velocities for each assemblage are estimated from mixing theory using laboratory measurements of the elastic parameters for pure mineral phases. The resultant velocities are then used to derive a direct relationship between $V_{p}$ and major element oxide composition, and the implications of this relationship for mantle melting systematics are explored. Finally, the calculated velocities are used to invert directly for major element chemistry as a function of $V_{p}$. Based on this inversion, we find the acceptable range of compositions for the middle and lower continental crust to be extremely large, ranging from basaltic to dacitic compositions. In the case of oceanic crust, observed lower crustal velocities are found to be $0.2-0.3 \mathrm{~km} / \mathrm{s}$ lower than velocities calculated based on the average bulk composition of oceanic gabbros in drill cores and exposed ophiolite sequences. We find the most
Table 1. Variance-Covariance Matrix for Seven Major Element Oxides in IGBA Database ${ }^{\mathrm{a}}$

\begin{tabular}{lccccccc}
\hline & \multicolumn{7}{c}{ Oxide } \\
\cline { 2 - 8 } Oxide & $\mathrm{SiO}_{2}$ & $\mathrm{Al}_{2} \mathrm{O}_{3}$ & $\mathrm{MgO}$ & $\mathrm{FeO}^{*}$ & $\mathrm{CaO}$ & $\mathrm{Na}_{2} \mathrm{O}$ & $\mathrm{K}_{2} \mathrm{O}$ \\
\hline $\mathrm{SiO}_{2}$ & 82.09 & & & & & & \\
$\mathrm{Al}_{2} \mathrm{O}_{3}$ & 2.67 & 10.77 & & & & & \\
$\mathrm{MgO}$ & -30.03 & -10.74 & 30.59 & & & & \\
$\mathrm{FeO}$ & -25.69 & -2.58 & 8.53 & 12.89 & & & \\
$\mathrm{CaO}$ & -25.66 & 0.60 & 6.76 & 8.51 & 13.95 & & \\
$\mathrm{Na}_{2} \mathrm{O}$ & 4.44 & 2.02 & -4.50 & -2.15 & -2.61 & 2.42 & \\
$\mathrm{~K}_{2} \mathrm{O}$ & 7.64 & 0.42 & -4.17 & -3.34 & -3.94 & 1.07 & 2.80 \\
\hline
\end{tabular}

${ }^{\mathrm{a}}$ Only the lower half of the symmetric matrix is shown. Note that the units of variance are $\mathrm{wt} \%^{2}$ and the total variance of the system is defined by the trace of the variance-covariance matrix (total variance = 155.51).

likely candidates for this discrepancy to be residual porosity at crustal depths less than $\sim 10 \mathrm{~km}$ and/or the presence of hydrous alteration phases in the lower crust, and suggest caution when inferring mantle melting parameters from observed velocities in the lower oceanic crust.

\section{Igneous Composition Space}

[7] We characterize the composition space of naturally occurring igneous and meta-igneous rocks (referred to hereafter as "igneous compostion space") using data from the IGBA database [Chayes, 1985; Brandle and Nagy, 1995]. IGBA contains $\sim 19,000$ volcanic and plutonic rock samples compiled from over 1300 sources across a broad spectrum of geologic environments. Of these samples, 18,637 include analyses on the 7 major element oxides, $\mathrm{SiO}_{2}, \mathrm{Al}_{2} \mathrm{O}_{3}, \mathrm{MgO}, \mathrm{FeO}^{*}(\mathrm{FeO}+$ $\left.0.9 \mathrm{Fe}_{2} \mathrm{O}_{3}\right), \mathrm{CaO}, \mathrm{Na}_{2} \mathrm{O}$, and $\mathrm{K}_{2} \mathrm{O}$. The variancecovariance matrix for the 7 major oxides is calculated in Table 1. The total variance of the oxide space is defined by the trace of the matrix, and the relative proportion explained by each oxide can be calculated by dividing the individual variance by the total variance. For example, $\mathrm{SiO}_{2}$ and $\mathrm{MgO}$ account for the largest share of the total variance, explaining $53 \%$ and $20 \%$, respectively.

[8] To further examine the structure of igneous composition space, we perform a principal component analysis on the 7 major element oxides in the IGBA database. The principal components of a 
Table 2. Eigenvectors and Eigenvalues of the Variance-Covariance Matrix in Table 1

\begin{tabular}{lcccccrc}
\hline & \multicolumn{5}{c}{ Eigenvector } \\
\cline { 2 - 7 } \multicolumn{1}{c}{ Oxide } & $\varepsilon_{\mathrm{I}}$ & $\varepsilon_{\mathrm{II}}$ & $\varepsilon_{\mathrm{III}}$ & $\varepsilon_{\mathrm{IV}}$ & $\varepsilon_{\mathrm{V}}$ & $\varepsilon_{\mathrm{VI}}$ & $\varepsilon_{\mathrm{VII}}$ \\
\hline $\mathrm{SiO}_{2}$ & 0.836 & -0.271 & 0.259 & -0.250 & -0.216 & -0.008 & 0.227 \\
$\mathrm{Al}_{2} \mathrm{O}_{3}$ & 0.067 & 0.533 & -0.522 & -0.276 & -0.547 & 0.187 & 0.168 \\
$\mathrm{MgO}$ & -0.370 & -0.748 & -0.299 & -0.259 & -0.270 & 0.013 & 0.273 \\
$\mathrm{FeO}$ & -0.274 & 0.093 & 0.590 & 0.372 & -0.564 & 0.088 & 0.322 \\
$\mathrm{CaO}$ & -0.269 & 0.252 & 0.377 & -0.706 & 0.295 & -0.073 & 0.362 \\
$\mathrm{Na}_{2} \mathrm{O}$ & 0.062 & 0.107 & -0.226 & 0.260 & 0.079 & -0.786 & 0.491 \\
$\mathrm{~K}_{2} \mathrm{O}$ & 0.090 & 0.004 & -0.172 & 0.299 & 0.412 & 0.577 & 0.608 \\
& & & & & & & \\
Eigenvalues & 113.42 & 24.71 & 6.78 & 5.74 & 2.93 & 1.27 & 0.65 \\
\% Variance & 72.94 & 15.89 & 4.36 & 3.69 & 1.89 & 0.82 & 0.42 \\
\hline
\end{tabular}

system correspond to the eigenvectors of the variance-covariance matrix, and represent the coordinate axes that most efficiently explain the total variance of the system assuming linear relationships between bulk composition and individual oxide components. The associated eigenvalues give the portion of the total variance explained by each eigenvector. The principal components of the IGBA oxide data are given in Table 2 and are illustrated as bar diagrams in Figure 1. Note that eigenvectors $\varepsilon_{\mathrm{I}}$ and $\varepsilon_{\mathrm{II}}$ explain $\sim 89 \%$ of the total variance in the oxide space, as compared to only $\sim 73 \%$ by $\mathrm{SiO}_{2}$ and $\mathrm{MgO}$.

[9] The applicability of the principal components to natural igneous systems can be interpreted in terms of the relationships between the major element oxides in each eigenvector. For example, the anti-correlation of $\mathrm{SiO}_{2}$ to $\mathrm{MgO}, \mathrm{FeO}^{*}$, and $\mathrm{CaO}$ in $\varepsilon_{\mathrm{I}}$ nicely describes the transition from felsic to mafic compositions, which accounts for $\sim 73 \%$ of the variance in the IGBA composition space. Likewise, the strong anti-correlation between $\mathrm{Al}_{2} \mathrm{O}_{3}$ and $\mathrm{MgO}$ in $\varepsilon_{\mathrm{II}}$ represents the progression from lavas to cumulates, and the anti-correlation of $\mathrm{MgO}$ and $\mathrm{FeO}^{*}$ in $\varepsilon_{\mathrm{IV}}$ separates primitive from relatively evolved, Fe-rich, basaltic lavas and cumulate gabbros.

\subsection{Generation of Synthetic Bulk Compositions}

[10] Using the principal components calculated above, we now construct a set of synthetic bulk compositions that spans the full range of igneous composition space. Synthetic compositions are calculated by taking linear combinations of $\varepsilon_{\mathrm{I}}, \varepsilon_{\mathrm{II}}$, $\varepsilon_{\mathrm{III}}, \varepsilon_{\mathrm{IV}}$, and $\varepsilon_{\mathrm{V}}$. We chose to sample only the first five principal components because these account for $\sim 99 \%$ of the total variance of the system. To determine the range over which to sample each component, we construct histograms of the principal component scores of the original oxide data (Figure 2). The principal component scores are calculated by projecting the original data onto each of the five eigenvectors. A uniform sampling scheme (see Figure 2) is chosen to insure that sampling biases in the IGBA database do not cause us to underrepresent certain regions of igneous composition space. This is particularly important as rocks found in the middle and lower crust may be less likely to be sampled at the surface. All linear combinations that result in either a negative value for one of the major element oxides or a total weight percent $<95 \%$ are eliminated, reducing the total number of synthetic bulk compositions from 15,925 to 479 .

[11] Figure 3 shows a comparison of the major element oxide distributions from the IGBA database and the synthetic compositions. The linear sampling scheme results in oxide distributions for the synthetic data that are broader than those for the original IGBA data. Our goal, however, is not to create a dataset that perfectly reproduces the major element chemistry of all igneous and meta-igneous rocks, but rather to generate a set of bulk compositions that fully encompasses possible igneous compositions. The synthetic distributions shown in Figure 3 satisfy our requirement, as the naturally occurring range of 

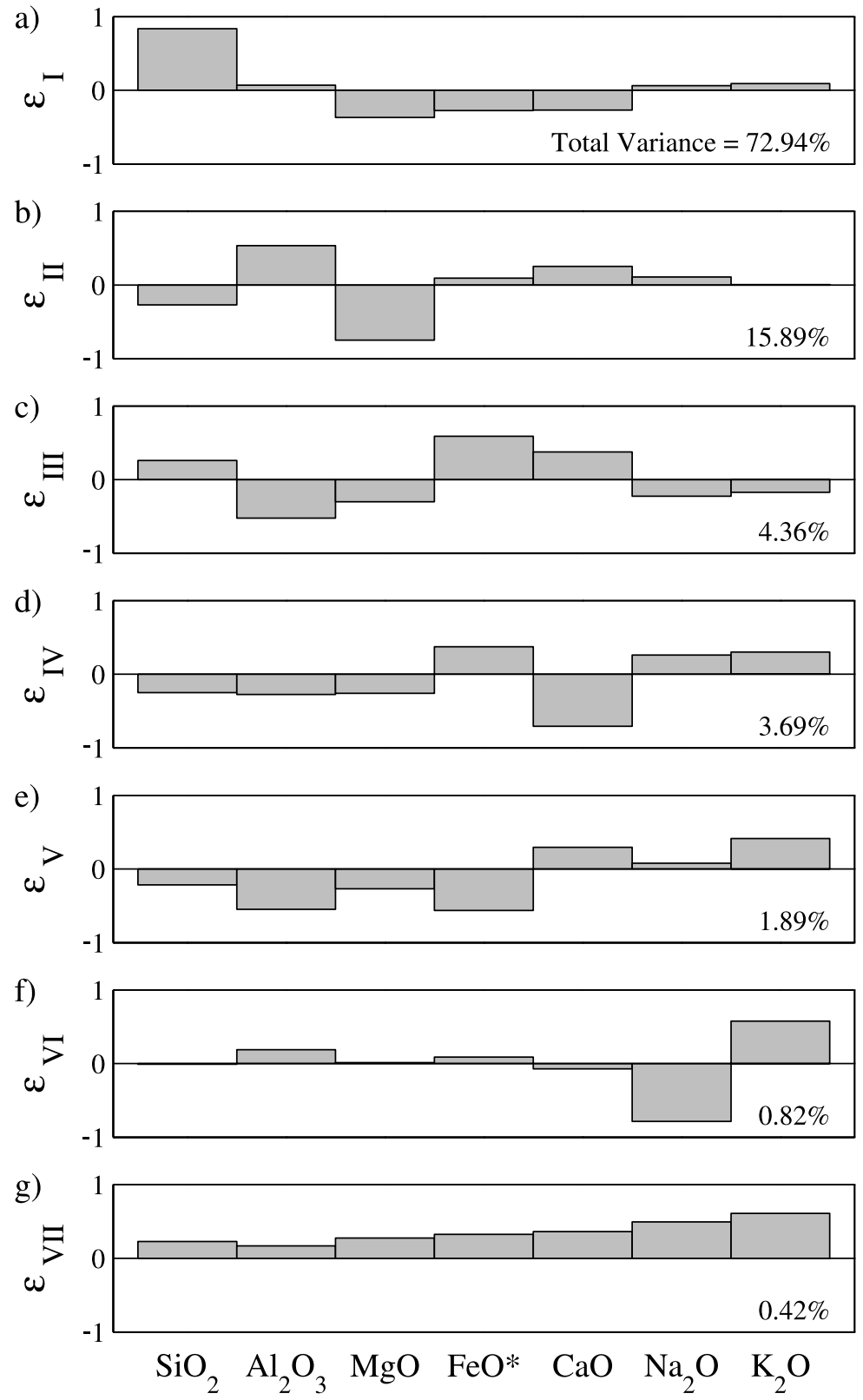

Figure 1. (a-g) Bar plots of principal components given in Table 2. Percentage of total variance described by each component is shown. Linear combinations of components $\varepsilon_{\mathrm{I}}, \varepsilon_{\mathrm{II}}, \varepsilon_{\mathrm{III}}, \varepsilon_{\mathrm{IV}}$, and $\varepsilon_{\mathrm{V}}$ are used to construct the synthetic composition space from which crystallizing phase assemblages are calculated.

each major oxide is represented by the synthetic compositions.

\section{Calculation of $V_{p}$ for Igneous Composition Space}

[12] To estimate seismic velocities for the bulk compositions in our synthetic data space, we calculate mineral assemblages at various equilibrium conditions and use the elastic moduli of the stable phases to place bounds on the seismic velocities. A number of previous workers have used a normative mineralogy-based approach to calculate hypothetical solid velocities for primary and residual liquids of mantle melts [e.g., White and McKenzie, 1989; Korenaga et al., 2002]. However, using CIPW norms to estimate equilibrium mineral assemblages rather than performing thermodynamic calculations, 
a)

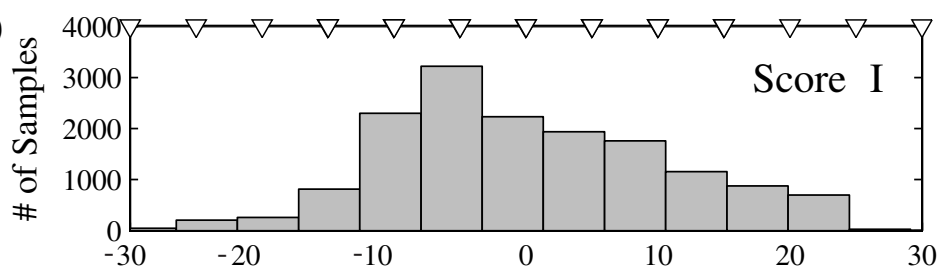

b)

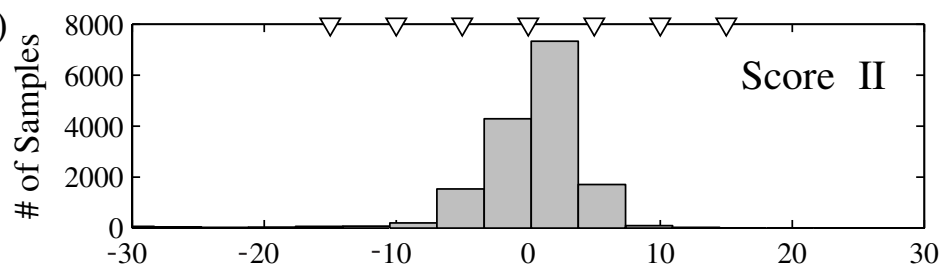

c)

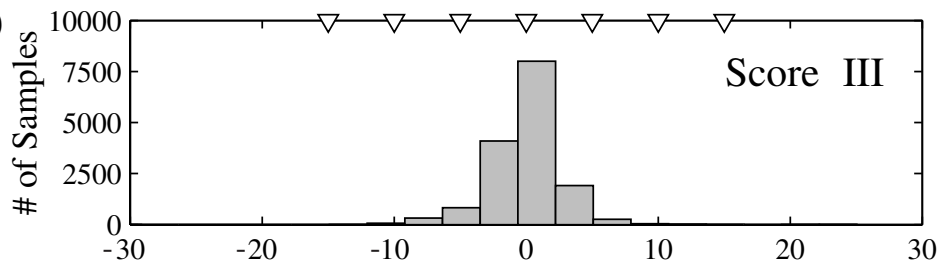

d)
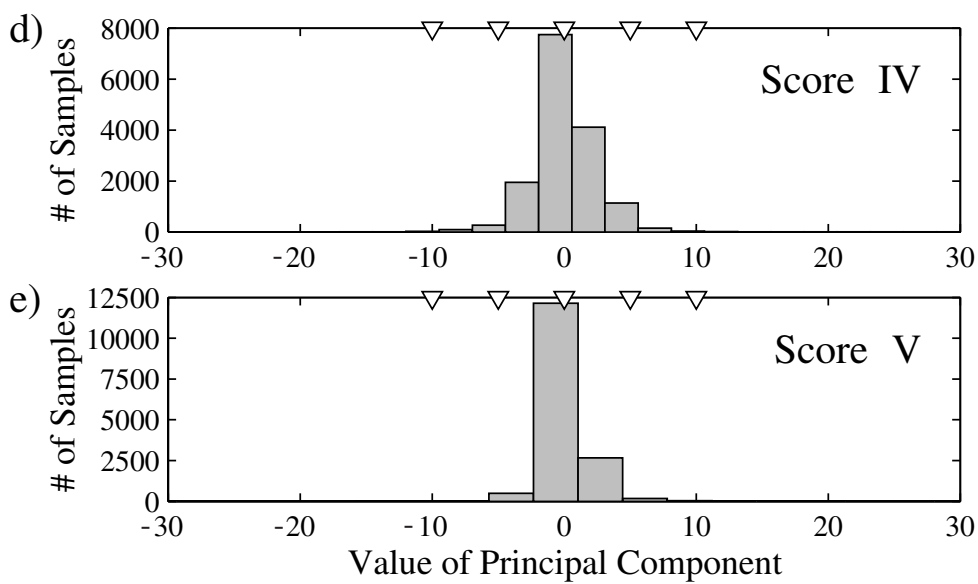

Figure 2. Histograms of principal component scores for (a) $\varepsilon_{\mathrm{I}}$, (b) $\varepsilon_{\mathrm{II}}$, (c) $\varepsilon_{\mathrm{III}}$, (d) $\varepsilon_{\mathrm{IV}}$, and (e) $\varepsilon_{\mathrm{V}}$. Triangles represent sampling points used to generate synthetic compositions. Principal component scores are referenced to the mean composition of the IGBA oxide data: $54.92 \mathrm{wt} \% \mathrm{SiO}_{2}, 15.66 \mathrm{wt} \% \mathrm{Al}_{2} \mathrm{O}_{3}, 5.16 \mathrm{wt} \% \mathrm{MgO}, 7.83 \mathrm{wt} \% \mathrm{FeO}^{*}(\mathrm{FeO} *$ signifies all $\mathrm{Fe}$ as $\mathrm{FeO}$ ), $7.09 \mathrm{wt} \% \mathrm{CaO}, 3.47 \mathrm{wt} \% \mathrm{Na}_{2} \mathrm{O}$, and $2.01 \mathrm{wt} \% \mathrm{~K}_{2} \mathrm{O}$.

ignores the possible presence of high pressure minerals such as garnet. Because of its high seismic velocity $\left(V_{p}>8.5 \mathrm{~km} / \mathrm{s}\right)$, even small amounts of garnet may significantly influence the overall velocity of a mineral assemblage. Thus, to assess the full range of igneous compositions that are consistent with a given seismic velocity, it is necessary to use a thermodynamic approach when estimating the equilibrium mineral assemblages [e.g., Sobolev and Babeyko, 1989, 1994; Babeyko et al., 1994].

[13] Subsolidus phase equilibrium calculations are performed using a free energy minimization algo- rithm developed by Connolly [1990] and the thermodynamic database of Holland and Powell [1998]. Only the 7 major element oxides used to construct the synthetic bulk compositions were included in the calculations. $\mathrm{TiO}_{2}$ and $\mathrm{P}_{2} \mathrm{O}_{5}$ were excluded for simplicity, as they are unlikely to affect the calculated subsolidus modes. For each synthetic composition, crystallizing mineral assemblages were calculated for an equilibration temperature, $T_{e q}$, of $800^{\circ} \mathrm{C}$ and equilibration pressures, $P_{\text {eq }}$, of $0.5,1,2,4,6,8,10,12,15$, and 20 kbar. We choose a single equilibration temperature of $800^{\circ} \mathrm{C}$ because this is a likely, 

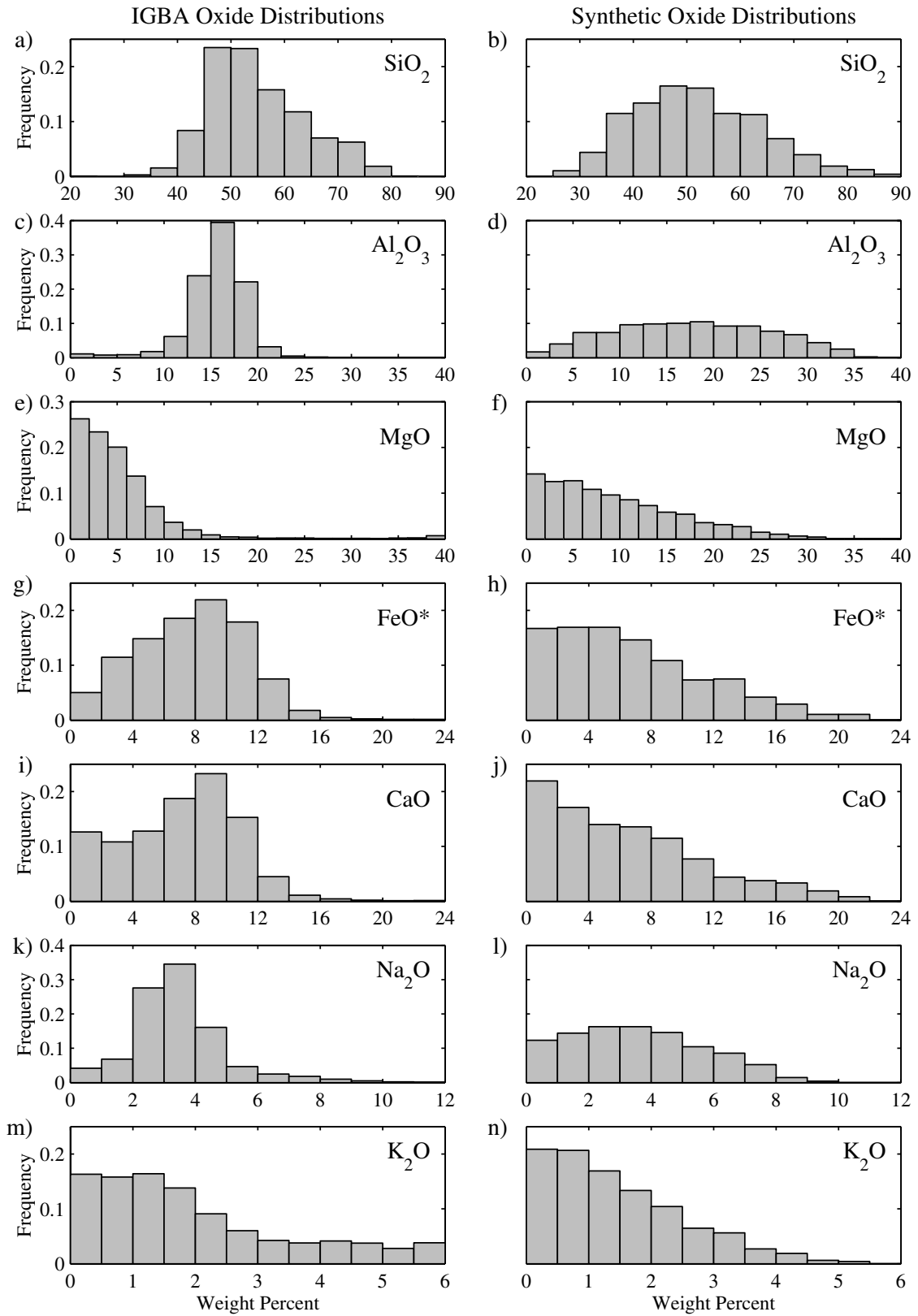

n)

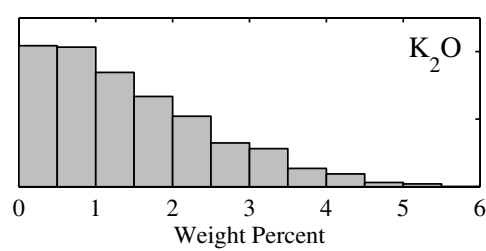

Figure 3. Observed frequency distributions for major oxides in IGBA database, (a) $\mathrm{SiO}_{2},(\mathrm{c}) \mathrm{Al}_{2} \mathrm{O}_{3},(\mathrm{e}) \mathrm{MgO},(\mathrm{g})$ $\mathrm{FeO}^{*}$, (i) $\mathrm{CaO}$, (k) $\mathrm{Na}_{2} \mathrm{O}$, (m) $\mathrm{K}_{2} \mathrm{O}$, and calculated frequency distributions for synthetic compositions, (b) $\mathrm{SiO}_{2}$, (d) $\mathrm{Al}_{2} \mathrm{O}_{3}$, (f) $\mathrm{MgO}$, (h) $\mathrm{FeO}^{*}$, (j) $\mathrm{CaO}$, (l) $\mathrm{Na}_{2} \mathrm{O}$, (n) $\mathrm{K}_{2} \mathrm{O}$. Note that synthetic oxide distributions are much broader than IGBA distributions.

lower bound for net-transfer reactions (nucleation and growth of new mineral phases) under anhydrous, lower crustal conditions [e.g., Austrheim, 1998; Hacker et al., 2000; B. Hacker, personal communication, 2001]. Equilibrium solutions were not found at one or more of the $P_{e q}, T_{e q}$ conditions for 56 of the 479 synthetic compositions. In general, these compositions lie near the limits of the synthetic data space and are not representative of naturally occurring igneous rock compositions.

[14] The calculated mineral assemblages are then used to estimate seismic velocities for each synthetic composition at the 10 equilibrium conditions. The weight proportions of the equilibrium 

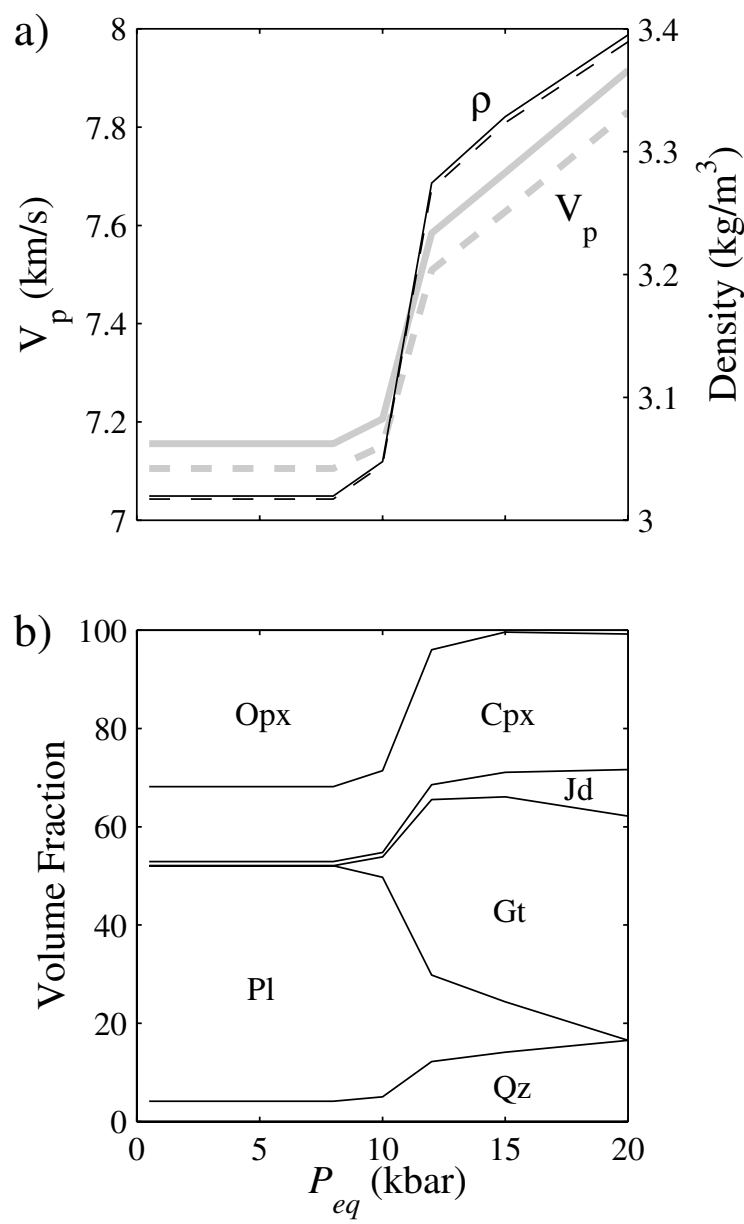

Figure 4. Sample calculation of the equilibrium mineral assemblage and corresponding $\mathrm{P}$-wave velocities for the synthetic bulk composition with $54.24 \mathrm{wt} \% \mathrm{SiO}_{2}$, $14.27 \mathrm{wt} \% \mathrm{Al}_{2} \mathrm{O}_{3}, 12.24 \mathrm{wt} \% \mathrm{MgO}, 6.98 \mathrm{wt} \% \mathrm{FeO}^{*}$, $10.88 \mathrm{wt} \% \mathrm{CaO}, 1.25 \mathrm{wt} \% \mathrm{Na}_{2} \mathrm{O}$, and $0.05 \mathrm{wt} \% \mathrm{~K}_{2} \mathrm{O}$. (a) Calculated density (black) and $V_{p}$ (gray) for the crystallizing assemblage at (1) $P_{r e f}=200^{\circ} \mathrm{C}$ and $T_{r e f}=3 \mathrm{kbar}$ (solid curves) and (2) $P_{r e f}=600^{\circ} \mathrm{C}$ and $T_{r e f}=10 \mathrm{kbar}$ (dashed curves). (b) Volume proportions of the crystallizing phases as a function of $P_{e q} . T_{e q}=800^{\circ} \mathrm{C}$ for all calculations. Mineral abbreviations are (Opx) orthopyroxene, (Cpx) clinopyroxene, (Pl) plagioclase, (Gt) garnet, (Qz) quartz, and (Jd) jadeite.

phases are converted into volume proportions using the mineral densities. Hashin-Shtrikman bounds [e.g., Hashin and Shtrikman, 1963; Watt et al., 1976; Berryman, 1995] are calculated for $V_{p}$ and $V_{s}$ of each multi-phase assemblage using compilations of densities and elastic moduli from Sobolev and Babeyko [1994] and Bass [1995]. For the bulk compositions in the synthetic data space the bounds are typically tighter than $0.12 \mathrm{~km} / \mathrm{s}$, and we use the average of the upper and lower bounds to estimate the velocity. We note that for mineral assemblages with strongly contrasting elastic properties (e.g., garnet and quartz) these bounds may be considerably larger $(>0.15 \mathrm{~km} / \mathrm{s})$. Figure 4 illustrates a sample calculation for one of the compositions in the synthetic data space. We note that the velocities calculated in this manner assume an anhydrous mineral assemblage with no residual porosity.

[15] Because pressure and temperature can strongly affect the seismic velocities of crustal and mantle rocks [e.g., Christensen, 1979], it is necessary to correct $V_{p}$ and $V_{s}$ to a reference pressure, $P_{r e f}$, and temperature, $T_{\text {ref }}$. We calculate the pressure and temperature effects before computing the HashinShtrikman bounds by correcting the elastic properties of the individual minerals using the compilation of P-, T-derivatives by Sobolev and Babeyko [1994]. Note that $P_{\text {ref }}$ and $T_{r e f}$ are independent of $P_{e q}$ and $T_{e q}$, with the former representing the pressure and temperature conditions at which the seismic velocity is measured and the latter referring to the conditions under which the sample equilibrated. We calculate values of $P_{r e f}$ and $T_{r e f}$ along a crustal geotherm for a depth range of $5-50 \mathrm{~km}$, assuming [Pollack and Chapman, 1977]

$$
P_{\text {ref }}=\rho g z
$$

and

$$
T_{r e f}=T_{o}+\frac{\left(q_{s}-q_{m}\right) d}{K}\left[1-\exp \left(\frac{-z}{d}\right)\right]+\frac{q_{m}}{K} z
$$

where $\rho$ is the average crustal density, $g$ is the gravitational acceleration, $z$ is depth, $T_{o}$ is the surface temperature, $q_{s}$ is the surface heat flow, $q_{m}$ is the mantle (or reduced) heat flow, $d$ is a characteristic depth scale, and $K$ is the thermal conductivity. We assume $\rho=2900 \mathrm{~kg} / \mathrm{m}^{3}, T_{o}=$ $10^{\circ} \mathrm{C}, d=10 \mathrm{~km}, K=3.35 \mathrm{~W} \mathrm{~m}^{-1}{ }^{\circ} \mathrm{K}^{-1}$, and $q_{m}$ to be $60 \%$ of $q_{s}$ for all calculations. Values of $q_{s}=35,56$, and $90 \mathrm{~mW} \mathrm{~m}^{-2}$ are used to simulate cold, normal, and warm crustal geotherms, respectively. Thus, for each synthetic bulk composition, $V_{p}$ is calculated at 100 different 
combinations of $P_{e q}, T_{e q}$ and $P_{r e f}, T_{r e f}$ along a particular geotherm.

\subsection{Comparison to Laboratory Data}

[16] Before analyzing the relationship between bulk composition and P-wave velocity using the synthetic data space, it is necessary to evaluate the ability of our approach to reproduce seismic velocities for known igneous compositions. We compiled high-quality laboratory data on 139 igneous and meta-igneous rocks for which both $V_{p}$ and major element composition are measured [Manghnani et al., 1974; Kern and Richter, 1981; Kern and Schenk, 1985; Christensen and Szymanski, 1988; Kern and Schenk, 1988; Christensen, 1989; Burke and Fountain, 1990; Fountain et al., 1990; Kern and Tubia, 1993; Miller and Christensen, 1994]. We limit our compilation to measurements of $V_{p}$ at $\geq 6 \mathrm{kbar}$ to simulate confining pressures appropriate for the middle and lower crust and to avoid the possible effect of microcracks on $V_{p}$ in experiments at low pressure. For samples in which velocities were measured in three orthogonal directions, the average value is used in the comparison. Equilibrium phase assemblages are calculated for the reported major element compositions over the range: $T_{e q}=500-$ $1000^{\circ} \mathrm{C}$ and $P_{e q}=2-12 \mathrm{kbar} . V_{p}, V_{s}$, and density are calculated for each equilibrium mode using the Hashin-Shtrikman bounds and the best-fit $V_{p}$ for each composition is determined. We choose to fit only $V_{p}$ because most density measurements were made at ambient pressure and temperature, increasing the risk of residual porosity, and $V_{S}$ data were available for only a small subset of samples. However, both the densities and the $V_{s}$ values calculated from the mineral assemblages fit for $V_{p}$ compare well to the laboratory data (Figure 5). The values of $P_{e q}$ and $T_{e q}$ corresponding to the best-fit $V_{p}$ for each sample are illustrated in Figure $5 \mathrm{~b}$. Based on our approach, the data for samples analyzed in the laboratory appear to be characterized by two principal styles of equilibration. The first occurs at a pressure of $\sim 1 \mathrm{GPa}$ and low temperature, while the second is characterized by equilibration at lower pressure over a wide range of temperatures.

[17] We also compared the calculated equilibrium phase proportions fit for $V_{p}$ with the observed phase proportions for samples on which pointcounts were performed (Figures 5e-5j). Overall the calculated phase proportions compare well with the observed phase proportions. The most important discrepancy is found in the prediction of olivine proportion, in which our equilibrium calculations often predict up to $20 \mathrm{wt} \%$ olivine even though none is observed in the laboratory sample. This discrepancy is probably due to the fact that we ignore both $\mathrm{Fe}^{3+}$ and $\mathrm{Cr}$ in our equilibrium calculations. The absence of these components suppresses reactions in which olivine reacts to form either spinel or magnetite, and thus leaves an excess of olivine in the calculated mineral assemblages. However, this excess olivine (plus plagioclase) has density and seismic velocity similar to the spinel + pyroxene assemblages that would replace it in a Cr-bearing system, and thus does not result in a systematic misfit for $V_{p}, V_{s}$, and density.

[18] A comparison of the best-fit $V_{p}$ data to the laboratory measurements at confining pressures $\geq 6$ kbar shows the calculated velocities overpredict the experimental data by $0.05 \pm 0.12 \mathrm{~km} / \mathrm{s}$ (Figure 5). This overprediction may be caused by residual porosity or the presence of alteration phases in the laboratory samples [e.g., Jackson et al., 1990]. To isolate the effect of porosity, we compare the best-fit $V_{p}$ to laboratory data for confining pressures ranging from 0.1 to $10 \mathrm{kbar}$ (Figure 6). In general, the residual between the best-fit and experimental velocities decreases with increasing confining pressure. At pressures $\leq 3 \mathrm{kbar}$, the calculated velocities overpredict the experimental data by $>0.15 \mathrm{~km} / \mathrm{s}$. However, for pressures $\geq 4 \mathrm{kbar}$ the best-fit and experimental velocities agree within error. This implies that microcracks are not completely closed below pressures of $\sim 3$ kbar or corresponding crustal depths shallower than $\sim 10 \mathrm{~km}$. Similar conclusions have been drawn from experimental studies that observe an increase in $V_{p}$ with confining pressure from $0-2 \mathrm{kbar}$ that is significantly more rapid than that predicted from the mineral compressibilities alone [e.g., Kern and Richter, 1981; Kern and Schenk, 1985, 1988].

[19] The scatter in the residuals is probably related to anisotropy in the laboratory data. Christensen 

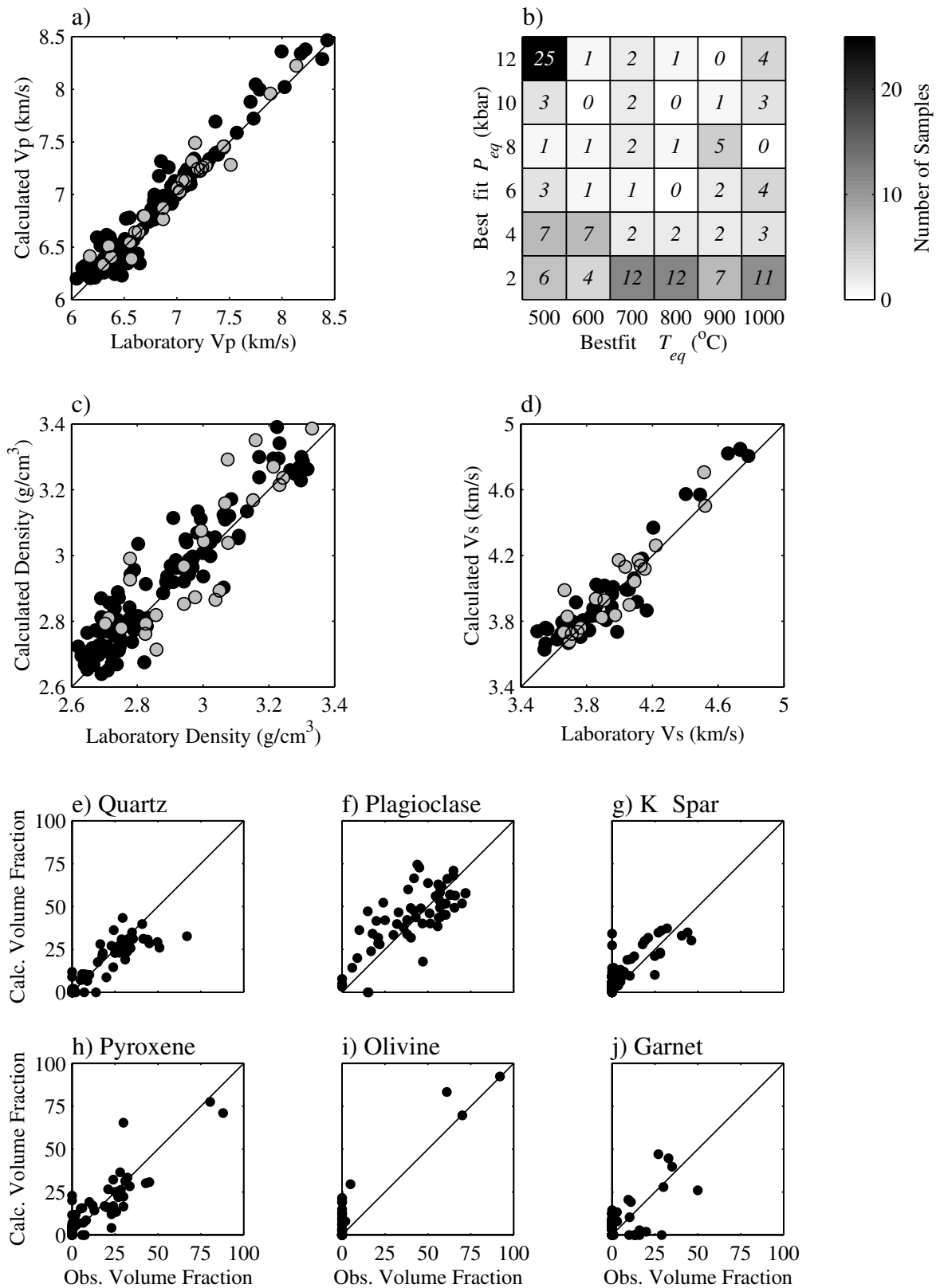

Figure 5. Comparison of calculated and laboratory determined $V_{p}$ in 139 igneous and meta-igneous rocks at $T_{\text {ref }}=$ $25^{\circ} \mathrm{C}$ and $\mathrm{P}_{\text {ref }} \geq 6$ kbar [Manghnani et al., 1974; Kern and Richter, 1981; Kern and Schenk, 1985; Christensen and Szymanski, 1988; Kern and Schenk, 1988; Christensen, 1989; Burke and Fountain, 1990; Fountain et al., 1990; Kern and Tubia, 1993; Miller and Christensen, 1994]. $V_{p}, V_{s}$, and density are calculated for each bulk composition from the equilibrium mode over a range of $T_{e q}=500-1000^{\circ} \mathrm{C}$ and $P_{e q}=2-12 \mathrm{kbar}$. The best-fit $V_{p}$ is then determined for each sample over the range of equilibrium conditions. (a) Best-fit $V_{p}$ versus experimentally determined $V_{p}$. For experimental data in which velocities were measured in multiple directions the average value is used in the comparison. Gray symbols represent samples containing garnet, black symbols represent samples that are garnet-free. The residuals of the best-fit data are calculated relative to a one-to-one correlation (black line), and have a mean $=$ 0.047 , median $=0.015$, and standard deviation $=0.125 \mathrm{~km} / \mathrm{s}$. (b) 2 -D histogram of best-fitting $T_{e q}$ and $P_{\text {eq }}$. Italic numbers indicate number of samples in each bin. (c) Calculated versus laboratory measured density using the equilibrium modes fit for $V_{p}$ (mean $=0.038$, median $=0.032$, and standard deviation $\left.=0.080 \mathrm{~g} / \mathrm{cm}^{3}\right)$. (d) Calculated versus laboratory $V_{s}$ using equilibrium modes fit for $V_{p}$ (mean $=0.037$, median $=0.036$, and standard deviation $=$ $0.114 \mathrm{~km} / \mathrm{s}, \mathrm{N}=66)$. (e)-(j) Comparison of major minerals in calculated and observed modes for samples on which point-count analyses were performed $(N=50)$. 


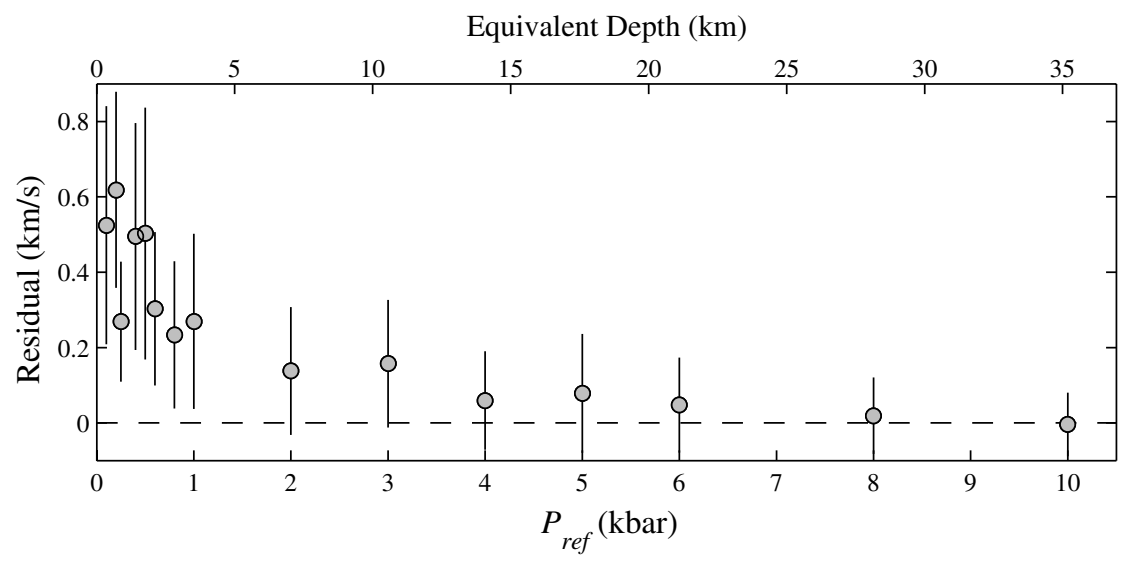

Figure 6. Comparison of the average residual between the best-fit $V_{p}$ and the laboratory data for confining pressures ranging from 0.1 to $10 \mathrm{kbar}$. Error bars represent the standard deviation in the residuals for each pressure. At confining pressures $\geq 4 \mathrm{kbar}$, the calculated and experimental velocities agree within error. However, for pressures $\leq 3 \mathrm{kbar}$, the best-fit $V_{p}$ overpredicts the experimental data by $>0.15 \mathrm{~km} / \mathrm{s}$.

and Mooney [1995] found the average $V_{p}$ anisotropy for igneous rocks to be $\sim 1-2 \%$ (or $0.07-$ $0.14 \mathrm{~km} / \mathrm{s}$ for $V_{p}=6.8 \mathrm{~km} / \mathrm{s}$ ). Of the 105 samples in our compilation for which $V_{p}$ was measured in multiple orthogonal directions, the mean standard deviation within each sample was $\pm 0.16 \mathrm{~km} / \mathrm{s}$. Thus, our approach for estimating $V_{p}$ from bulk composition is accurate within the precision of the experimental data, and we conclude that $V_{p}$ calculated in this manner will be representative of the true seismic velocity of an equilibrium mineral assemblage in the absence of residual porosity.

\section{Relating $V_{p}$ to Igneous Rock Composition}

[20] The P-wave velocities calculated from the synthetic data are now used to develop a number of tools to infer compositional information from measurements of seismic velocity. Multiple linear regression is used to construct a direct relationship between $V_{p}$ and major element oxide composition over the full spectrum of igneous composition space. The resulting relationship can be used to predict $V_{p}$ from bulk composition and further to constrain mantle melting parameters (i.e., pressure and melt fraction) in conjunction with seismic observations [e.g., Kelemen and Holbrook, 1995; Korenaga et al., 2002]. Finally, by inverting directly for major element oxide chemistry as a function of $V_{p}$, we address the fundamental problem facing all seismic inferences of crustal composition; namely, if only $V_{p}$ is known, what is the full range of compositions that are consistent with the seismic observations?

\subsection{Direct Relationship Between $V_{p}$ and Major Element Oxide Composition}

[21] Kelemen and Holbrook [1995] used experimental data to derive an empirical relationship between $V_{p}$ and major element oxide composition for garnet-free igneous and meta-igneous rocks at a reference state of $600 \mathrm{MPa}$ and $400^{\circ} \mathrm{C}$,

$$
V_{p}=7.854-0.024 \mathrm{wt} \% \mathrm{SiO}_{2}+0.029 \mathrm{wt} \% \mathrm{MgO} .
$$

This function has an accuracy of $\pm 0.19 \mathrm{~km} / \mathrm{s}(1 \sigma)$ and was not improved by adding additional oxides to the regression. A significant source of error in equation (3) is the difficulty in making seismic velocity measurements on laboratory samples discussed above. Further, the applicability of this relationship is limited by the range of compositions for which experimental data were available.

[22] Following a similar approach to Kelemen and Holbrook [1995], we use the P-wave velocities calculated from the synthetic data to construct a linear relationship between $V_{p}$ and composition that is valid for all igneous compositions. Multiple linear regression results in the following function 
relating $V_{p}$ to $\mathrm{SiO}_{2}, \mathrm{MgO}$, and $\mathrm{CaO}$ for all $P_{\text {ref }}$ and $T_{\text {ref }}$ conditions along a normal crustal geotherm in the depth range from 5-50 km with $P_{e q} \leq 12 \mathrm{kbar}$ (Figure 7),

$$
\begin{aligned}
V_{p}= & 6.90-0.011 \mathrm{wt} \% \mathrm{SiO}_{2}+0.037 \mathrm{wt} \% \mathrm{MgO} \\
& +0.045 \mathrm{wt} \% \mathrm{CaO}
\end{aligned}
$$

This function has an accuracy of $\pm 0.13 \mathrm{~km} / \mathrm{s}(1 \sigma)$. We choose to include only $\mathrm{SiO}_{2}, \mathrm{MgO}$, and $\mathrm{CaO}$ in the analysis as the addition of other oxides does not significantly improve the fit, and regression with only $\mathrm{SiO}_{2}$ and $\mathrm{MgO}$ is insufficient to explain the variation in the $V_{p}$ data (Table 3, R-4 and R-5). Including equilibration pressures greater than 12 kbar significantly degrades the quality of the regression $\left(P_{e q} \leq 15 \mathrm{kbar}, 1 \sigma= \pm 0.24 \mathrm{~km} / \mathrm{s} ; P_{e q} \leq\right.$ $20 \mathrm{kbar}, 1 \sigma= \pm 0.33 \mathrm{~km} / \mathrm{s}$ ) due to the formation of garnet at high pressure (Table 3, R-2 and R-3). The resulting high garnet modes (often $>25 \mathrm{wt} \%$ garnet) are characterized by higher $V_{p}$ than that predicted from equation (4). Geologic examples of rocks with high modal garnet $(20-40 \%)$ are found in the Kohistan accreted arc terrane, northern Pakistan [Miller and Christensen, 1994] and in mafic granulite xenoliths from the Chudleigh volcanic province, north Queensland, Australia [Rudnick and Jackson, 1995]. In addition to garnet, high modal jadeite $\left(V_{p}=8.6 \mathrm{~km} / \mathrm{s}\right)$ is also found at high pressures dissolved in clinopyroxene solid solution due to the albite-out reaction $(\mathrm{Ab}=\mathrm{Jd}+$ Qz). In summary, these high pressure assemblages may cause equation (4) to significantly underestimate $V_{p}$ in regions where crustal thickness exceeds $35-40 \mathrm{~km}$.

[23] To address this issue we derived separate functions relating composition to $V_{p}$ for high pressure conditions $\left(P_{e q}=12,15\right.$, and $\left.20 \mathrm{kbar}\right)$. The relationships have the form:

$$
\begin{aligned}
V_{p}= & a_{0}+b_{1} \mathrm{Mg}+c_{1} \mathrm{Ca}+d_{1} \mathrm{Si}+d_{2} \mathrm{Si}^{2}+d_{3} \mathrm{Si}^{3}+d_{4} \mathrm{Si}^{4} \\
& +d_{5} \mathrm{Si}^{5}+d_{6} \mathrm{Si}^{6}+e_{1} \mathrm{Na}+e_{2} \mathrm{Na}^{2}+e_{3} \mathrm{Na}^{3}+e_{4} \mathrm{Na}^{4} \\
& +f_{1} \mathrm{SiNa}+f_{2} \mathrm{Si}^{2} \mathrm{Na}+f_{3} \mathrm{SiNa}^{2}+f_{4} \mathrm{Si}^{2} \mathrm{Na}^{2}
\end{aligned}
$$

where $\mathrm{Mg}, \mathrm{Ca}, \mathrm{Si}$ and $\mathrm{Na}$ represent weight percent $\mathrm{MgO}, \mathrm{CaO}, \mathrm{SiO}_{2}$, and $\mathrm{Na}_{2} \mathrm{O}$, respectively. The regression coefficients are listed in Table 4 . These relationships have $1 \sigma$ errors of $0.12,0.24$, and 0.20
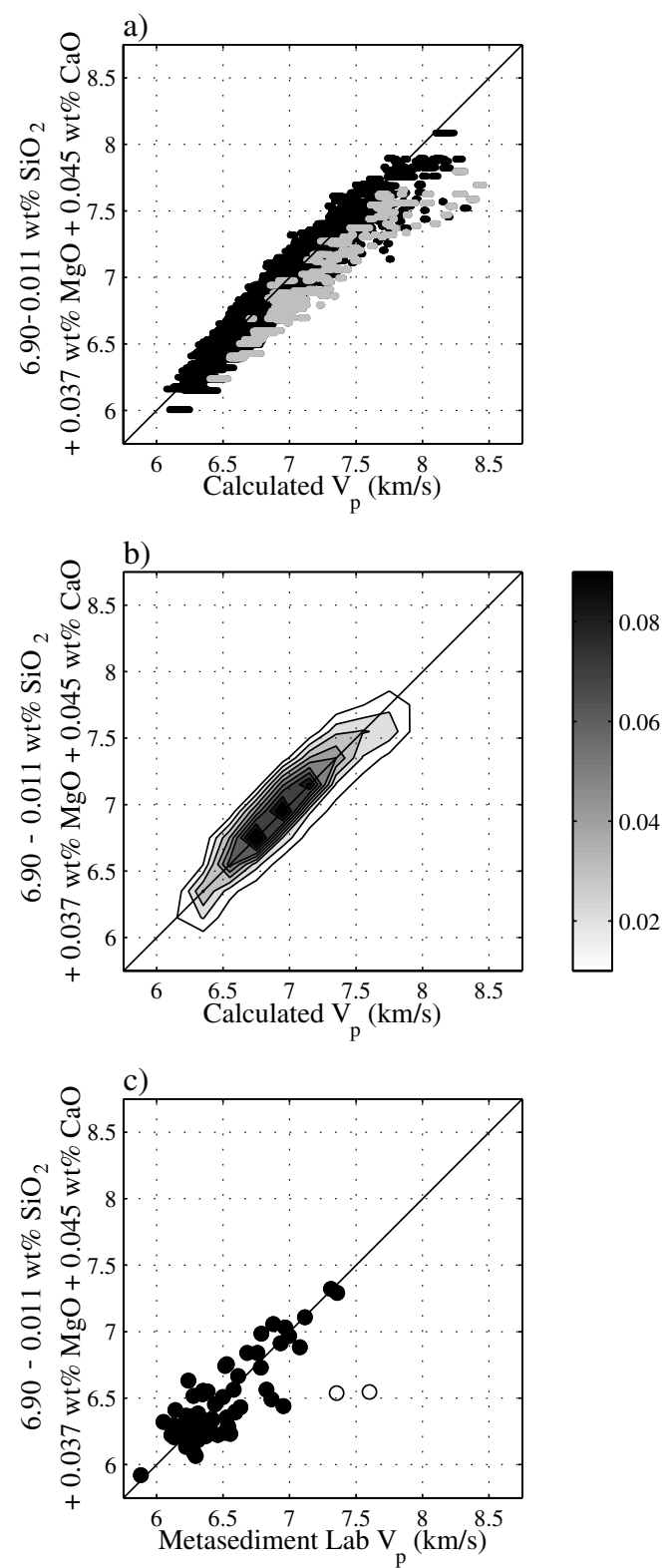

Figure 7. (a) Results of multiple linear regression fit of major element oxide composition to $V_{p}$ calculated from the synthetic data along a normal crustal geotherm with $P_{e q} \leq 12$ kbar. Gray symbols represent synthetic compositions containing $>25 \mathrm{wt} \%$ garnet. The resulting function is characterized by $N=30,710, r^{2}=0.90$, and $1 \sigma= \pm 0.13 \mathrm{~km} / \mathrm{s}$. The addition of other oxides, such as $\mathrm{Al}_{2} \mathrm{O}_{3}, \mathrm{FeO}, \mathrm{Na}_{2} \mathrm{O}$, and $\mathrm{K}_{2} \mathrm{O}$ did not significantly improve the fit (see Table 3). (b) Data density plot, calculated by contouring the normalized number of observations in $0.1 \times 0.1 \mathrm{~km} / \mathrm{s}$ bins. Note that the garnet-bearing samples do not represent a signficant fraction of the data space. (c) Comparison of laboratory data with $V_{p}$ calculated from equation (4) for 69 metasedimentary rocks. After eliminating two outliers (open symbols) the residuals have a mean $=0.025 \mathrm{~km} / \mathrm{s}$ and a stardard deviation $=0.18 \mathrm{~km} / \mathrm{s}$. 
Table 3. Results of Multiple Linear Regression to Relate $V_{p}$ to Major Element Oxide Composition for the Synthetic Data Space $^{\mathrm{a}}$

\begin{tabular}{|c|c|c|c|c|c|c|c|c|}
\hline \multirow[b]{2}{*}{ Oxide } & \multicolumn{7}{|c|}{ Regression Coefficients } & \multirow[b]{2}{*}{ KH95 } \\
\hline & $\mathrm{R}-1$ & $\mathrm{R}-2$ & $\mathrm{R}-3$ & $\mathrm{R}-4$ & $\mathrm{R}-5$ & R-6 & $\mathrm{R}-7$ & \\
\hline $\mathrm{SiO}_{2}$ & -0.011 & -0.014 & -0.016 & -0.93 & -0.017 & -0.010 & -0.012 & -0.024 \\
\hline $\mathrm{Al}_{2} \mathrm{O}_{3}$ & - & - & - & -0.97 & - & - & - & - \\
\hline $\mathrm{MgO}$ & 0.037 & 0.036 & 0.034 & -0.89 & 0.028 & 0.038 & 0.035 & 0.029 \\
\hline $\mathrm{FeO}^{*}$ & - & - & - & -0.94 & - & - & - & - \\
\hline $\mathrm{CaO}$ & 0.045 & 0.042 & 0.038 & -0.85 & - & 0.045 & 0.045 & - \\
\hline $\mathrm{Na}_{2} \mathrm{O}$ & - & - & - & -0.69 & - & - & - & - \\
\hline $\mathrm{K}_{2} \mathrm{O}$ & - & - & - & -1.12 & - & - & - & - \\
\hline Constant & 6.90 & 7.13 & 7.39 & 99.27 & 7.62 & 6.90 & 6.89 & 7.854 \\
\hline$P_{e q}^{\max }(\mathrm{kbar})$ & 12 & 15 & 20 & 12 & 12 & 12 & 12 & N.A. \\
\hline$q_{s}\left(\mathrm{~mW} \mathrm{~m} \mathrm{~m}^{-2}\right)$ & 56 & 56 & 56 & 56 & 56 & 35 & 90 & N.A. \\
\hline $1 \sigma$ & 0.13 & 0.24 & 0.33 & 0.12 & 0.26 & 0.14 & 0.13 & 0.19 \\
\hline$r^{2}$ & 0.90 & 0.74 & 0.59 & 0.91 & 0.62 & 0.89 & 0.90 & 0.89 \\
\hline
\end{tabular}

${ }^{\text {a }}$ Results are shown for $V_{p}$ calculated from the synthetic bulk compositions at all $P_{r e f}$ and $T_{r e f}$ conditions in the depth range of $5-50 \mathrm{~km}$ along a cold, normal, and warm crustal geotherm. Samples with $P_{e q}>P_{e q}^{\max }$ were eliminated from the regression. KH95 illustrates the empirical relation derived by Keleman and Holbrook [1995] from laboratory data at a reference state of $600 \mathrm{MPa}$ and $400^{\circ} \mathrm{C}$.

$\mathrm{km} / \mathrm{s}$ for $P_{e q}=12,15$, and $20 \mathrm{kbar}$, respectively. The higher order terms are necessary to accurately describe the formation of garnet and jadeite at high pressure. Note that the regression coefficients are highly sensitive to pressure, requiring separate relationships be used for different values of $P_{e q}$.

[24] We also tested the sensitivity of the regression coefficients to the crustal geotherm by recalculating the regression with $P_{e q} \leq 12 \mathrm{kbar}$ using $V_{p}$ data corrected for $P_{\text {ref }}$ and $T_{\text {ref }}$ along both a cold and warm geotherm (Table 3, R-6 and R-7). Calculating $V_{p}$ for each synthetic bulk composition using the regression functions derived for the cold and warm geotherms results in average velocity differences of 0.08 and $-0.08 \mathrm{~km} / \mathrm{s}$, respectively, from the values calculated using equation (4). These differences are consistent with the predicted variations in $V_{p}$ calculated along each geotherm using typical pressure $\left(\sim 2 \times 10^{-4} \mathrm{~km} \mathrm{~s}^{-1} \mathrm{MPa}^{-1}\right)$ and temperature derivatives $\left(\sim 4 \times 10^{-4} \mathrm{~km} \mathrm{~s}^{-1}{ }^{\circ} \mathrm{C}^{-1}\right)$ from the literature [e.g., Christensen, 1979; Kern, 1982; Fountain and Christensen, 1989; Jackson, 1991; Christensen and Mooney, 1995].

[25] The relationship in equation (4) was derived from the suite of synthetic compositions generated to span igneous composition space. However, while oceanic crust is igneous in origin, high-grade metamorphic assemblages may constitute a major component of the middle and lower continental crust [e.g., Rudnick and Fountain, 1995]. Therefore, to insure that the derived relationship is not specific to igneous compositions, it is desirable to test the ability of equation (4) to reproduce P-wave velocities for metasedimentary rocks. Compiling laboratory data on 69 metasedimentary samples for which

Table 4. Results of Multiple Linear Regression to Relate $V_{p}$ to Major Element Oxide Composition for $P_{e q}=12,15$, and $20 \mathrm{kbar}^{\mathrm{a}}$

\begin{tabular}{lrrr}
\hline$P_{e q}=$ & \multicolumn{1}{c}{$12 \mathrm{kbar}$} & \multicolumn{1}{c}{$15 \mathrm{kbar}$} & \multicolumn{1}{c}{$20 \mathrm{kbar}$} \\
\hline$a_{0}$ & $2.92 \mathrm{e}+01$ & $2.40 \mathrm{e}+02$ & $2.90 \mathrm{e}+02$ \\
$b_{1}$ & $1.54 \mathrm{e}-02$ & $2.00 \mathrm{e}-02$ & $1.67 \mathrm{e}-02$ \\
$c_{1}$ & $2.28 \mathrm{e}-02$ & $9.83 \mathrm{e}-03$ & $1.35 \mathrm{e}-02$ \\
$d_{1}$ & $-2.66 \mathrm{e}+00$ & $-2.87 \mathrm{e}+01$ & $-3.43 \mathrm{e}+01$ \\
$d_{2}$ & $1.31 \mathrm{e}-01$ & $1.39 \mathrm{e}+00$ & $1.65 \mathrm{e}+00$ \\
$d_{3}$ & $-3.28 \mathrm{e}-03$ & $-3.45 \mathrm{e}-02$ & $-4.05 \mathrm{e}-02$ \\
$d_{4}$ & $4.40 \mathrm{e}-05$ & $4.62 \mathrm{e}-04$ & $5.42 \mathrm{e}-04$ \\
$d_{5}$ & $-3.02 \mathrm{e}-07$ & $-3.21 \mathrm{e}-06$ & $-3.76 \mathrm{e}-06$ \\
$d_{6}$ & $8.40 \mathrm{e}-10$ & $9.05 \mathrm{e}-09$ & $1.06 \mathrm{e}-08$ \\
$e_{1}$ & $3.66 \mathrm{e}-01$ & $2.48 \mathrm{e}+00$ & $2.71 \mathrm{e}+00$ \\
$e_{2}$ & $-4.96 \mathrm{e}-02$ & $-1.71 \mathrm{e}-01$ & $-3.50 \mathrm{e}-01$ \\
$e_{3}$ & $7.43 \mathrm{e}-03$ & $6.20 \mathrm{e}-03$ & $1.18 \mathrm{e}-02$ \\
$e_{4}$ & $-3.07 \mathrm{e}-04$ & $-5.35 \mathrm{e}-04$ & $-5.52 \mathrm{e}-04$ \\
$f_{1}$ & $-8.73 \mathrm{e}-03$ & $-7.86 \mathrm{e}-02$ & $-8.33 \mathrm{e}-02$ \\
$f_{2}$ & $3.92 \mathrm{e}-05$ & $5.83 \mathrm{e}-04$ & $6.72 \mathrm{e}-04$ \\
$f_{3}$ & $-1.34 \mathrm{e}-03$ & $4.39 \mathrm{e}-03$ & $1.01 \mathrm{e}-02$ \\
$f_{4}$ & $2.37 \mathrm{e}-05$ & $-2.82 \mathrm{e}-05$ & $-9.34 \mathrm{e}-05$ \\
& & & 0.20 \\
$1 \sigma$ & 0.13 & 0.24 & 0.90 \\
$r^{2}$ & 0.92 & 0.85 & \\
\hline
\end{tabular}

${ }^{\mathrm{a}}$ Regression coefficients correspond to those shown in equation (5). Results are given for $V_{p}$ calculated from the synthetic bulk compositions at all $P_{\text {ref }}$ and $T_{\text {ref }}$ conditions in the depth range of 5$50 \mathrm{~km}$ along a normal crustal geotherm. 
both composition and velocity data are available [Kern and Richter, 1981; Christensen and Szymanski, 1988; Kern and Schenk, 1988; Christensen, 1989; Burke and Fountain, 1990; Fountain et al., 1990; Kern and Tubia, 1993; Miller and Christensen, 1994], we use equation (4) to predict $V_{p}$ from the reported major element oxides and compare the predicted values to laboratory measurements at $\geq 6$ kbar (Figure 7c). The resulting residuals were found to have a mean value of $0.025 \mathrm{~km} / \mathrm{s}$ and a standard deviation of $0.18 \mathrm{~km} / \mathrm{s}$. We note that the standard deviation is slightly higher than the $1 \sigma$ error bounds for the regression in equation (4). However, this discrepancy can be attributed to the high average anisotropy in metasediments, for which the mean standard deviation of orthogonal velocity measurements on a single sample is $\pm 0.28 \mathrm{~km} / \mathrm{s}$. Thus, it appears that equation (4) can be used to predict $V_{p}$ from bulk composition for both igneous and metasedimentary rocks.

\subsection{Relating $V_{p}$ to the Pressure and Fraction of Melting}

[26] Using the relationship derived in equation (4) we now investigate the connection between mantle melting systematics and the velocity structure of the resultant igneous crust [e.g., Kelemen and Holbrook, 1995; Korenaga et al., 2002]. Compiling high-quality data from anhydrous melting experiments of mantle peridotites [Kinzler and Grove, 1992; Kinzler and Grove, 1993; Hirose and Kushiro, 1993; Baker and Stolper, 1994; Baker et al., 1995; Kinzler, 1997; Walter, 1998], we follow the approach of Kelemen and Holbrook [1995] to relate $V_{p}$ to the pressure and fraction of melting. $V_{p}$ is calculated for the experimental liquids using equation (4), and multiple linear regression results in the following relationship valid for all $P_{\text {ref }}$ and $T_{\text {ref }}$ conditions along a normal crustal geotherm in the depth range from $5-50 \mathrm{~km}$ and $P_{e q} \leq 12 \mathrm{kbar}$ (Figure 8),

$$
V_{p}=7.03+0.14 P+0.97 F-0.006 P^{2}-0.17 P F+0.29 F^{2},
$$

where $P$ is the pressure of melting in GPa and $F$ is the melt fraction. The regression has a standard deviation of $\sim 0.06 \mathrm{~km} / \mathrm{s}$. However the true error associated with equation (6) is higher, due to the

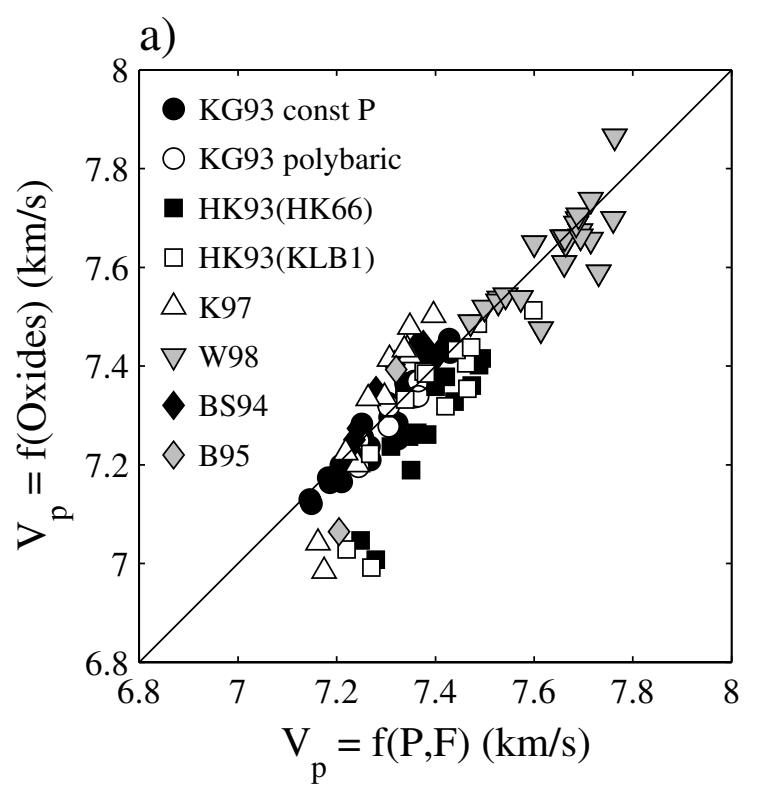

b)

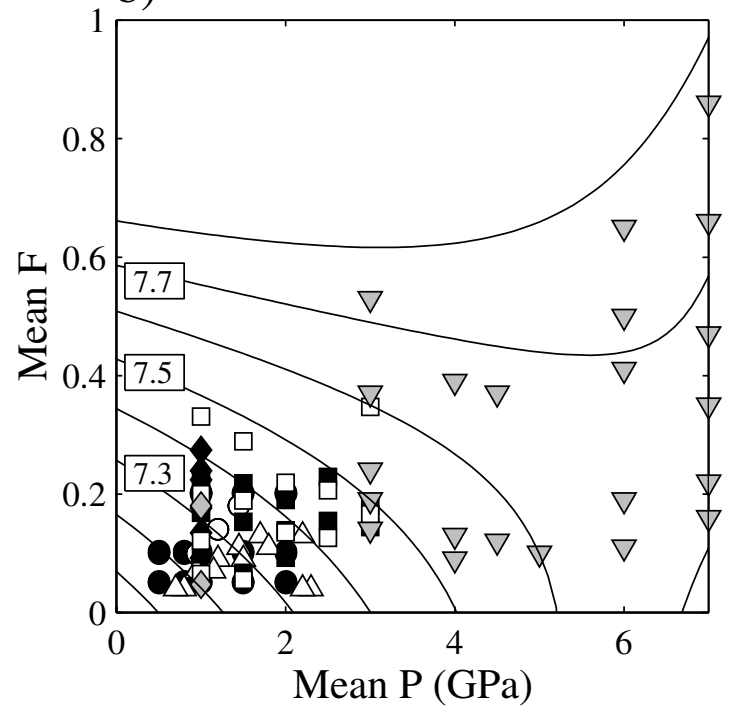

Figure 8. (a) Relationship of $V_{p}$, calculated from equation (4), to the pressure and fraction of melting for experimental and calculated anhydrous liquids in equilibrium with mantle lherzolite [Kinzler and Grove, 1992; Kinzler and Grove, 1993; Baker and Stolper, 1994; Baker et al., 1995; Walter, 1998]. Melting data of Baker and Stolper [1994] and Baker et al. [1995] were corrected after Hirschmann et al. [1998]. The resulting regression function is given in equation (6) and is characterized by $N=76, r^{2}=0.90$, and $1 \sigma= \pm 0.06 \mathrm{~km} / \mathrm{s}$. Note that the mantle melts of Hirose and Kushiro [1993] were not included in the regression (see text for discussion). (b) Mantle melt data as a function of the pressure and fraction of melting. Contours illustrate predicted $\mathrm{P}$-wave velocities calculated from equation (6). 
uncertainty in estimating $V_{p}$ from the composition of the mantle melts. The data of Hirose and Kushiro [1993] and Kinzler [1997] were not included in the regression. Hirose and Kushiro [1993] calculated melt fraction from the $\mathrm{Na}_{2} \mathrm{O}$ concentration in the melt, which has been shown to overestimate the true melt fraction [e.g., Kogiso et al., 1998]. Further, half of the Hirose and Kushiro [1993] melting data are on pyroxenite, which may not represent a typical mantle source composition. We note that using likely values of mean $P$ and $F$ for melting beneath mid-ocean ridges (i.e., $\bar{P} \sim 1-$ 2 GPa and $\bar{F} \sim 7-10 \%$ ) in equation (6) gives $V_{p}>$ $7.2 \mathrm{~km} / \mathrm{s}$, whereas seismic measurements of $V_{p}$ in average lower oceanic crust typically range from 6.9 to $7.0 \mathrm{~km} / \mathrm{s}$ [Raitt, 1963; Shor et al., 1970; Christensen and Salisbury, 1975; White et al., 1992]. We will discuss this discrepancy in more detail in Section 5.2.

\subsection{Inverting Bulk Composition from Measurements of $V_{p}$}

[27] Previous workers have constrained the range of bulk compositions that are consistent with a particular seismic velocity by extrapolating laboratory measurements on a wide range of rock types to typical geologic conditions [e.g., Birch, 1958; Pakiser and Robinson, 1966; Fountain and Christensen, 1989; Holbrook et al., 1992; Christensen and Mooney, 1995; Rudnick and Fountain, 1995]. However, this approach does not predict formal bounds on bulk composition and is limited by the range of rock types for which laboratory data are available. In contrast, we use the P-wave velocities calculated from the synthetic data to directly assess the range of igneous compositions that are consistent with a particular seismic velocity, assuming only a reference geotherm.

[28] For P-wave velocities ranging from 6.2$7.6 \mathrm{~km} / \mathrm{s}$, we search the synthetic data space for all bulk compositions that result in a $V_{p}$ within $\pm 0.1 \mathrm{~km} / \mathrm{s}$ of the desired velocity at $P_{r e f}$ and $T_{r e f}$ along a particular geotherm. A bin width of $0.2 \mathrm{~km} / \mathrm{s}$ was chosen to represent the minimum error in lower crustal P-wave velocity associated with a well-constrained seismic experiment [e.g., Korenaga et al., 2000], although in reality the error associated with many lower crustal velocity measurements may be significantly higher due to poor ray coverage in the lower crust and the tradeoff between velocity and crustal thickness. Because $V_{p}$ is a function of $P_{r e f}$ and $T_{r e f}$ it is necessary to assess the bulk compositions consistent with each velocity at specific depth intervals along a geotherm. Tables A.1, A.2, and A.3 give the mean and standard deviation in weight percent of the major element oxides for each velocity bin along a normal, cold, and warm crustal geotherm, respectively. In general, the skewness in the major element oxide distributions is small and thus the standard deviation is a good approximation for the $67 \%$ confidence bounds. However, because our synthetic composition space is not weighted by the frequency of naturally occurring bulk compositions, it is important to remember that the values in Tables A.1-A.3 represent compositional bounds only, and the mean values do not necessarily reflect the average bulk composition associated with a specific velocity in the lower crust.

[29] The first observation that can be made from Tables A.1-A.3 is that the range of bulk compositions consistent with a given $V_{p}$ is quite large. This implies that without additional information, Pwave measurements alone will seldom be sufficient to distinguish between competing models for middle and lower crustal composition. However, while this observation may be discouraging for those hoping to infer compositional information from seismic data, the results compiled in Tables A.1A.3 indicate that $V_{p}$ can be used to place some useful constraints on bulk composition. For example, Figure 9 illustrates the variations in major element oxide composition as a function of $V_{p}$ at a depth of $30 \mathrm{~km}$ along a typical crustal geotherm. With the exception of $\mathrm{FeO}$, all the major element oxides vary as a function of $V_{p}$. The transition from low-velocity, felsic compositions to high-velocity, mafic compositions is clearly seen in the negative correlation of $V_{p}$ to mean $\mathrm{SiO}_{2}$ content and the positve correlation of $V_{p}$ to mean $\mathrm{MgO}$ and $\mathrm{CaO}$ content. Moreover, the variability in $\mathrm{MgO}$ and $\mathrm{CaO}$ content increases steadily with increasing $V_{p}$, due to the trade-off in $\mathrm{MgO}$ and $\mathrm{CaO}$ content in many high-velocity mineral phases (e.g., clinopyroxene 

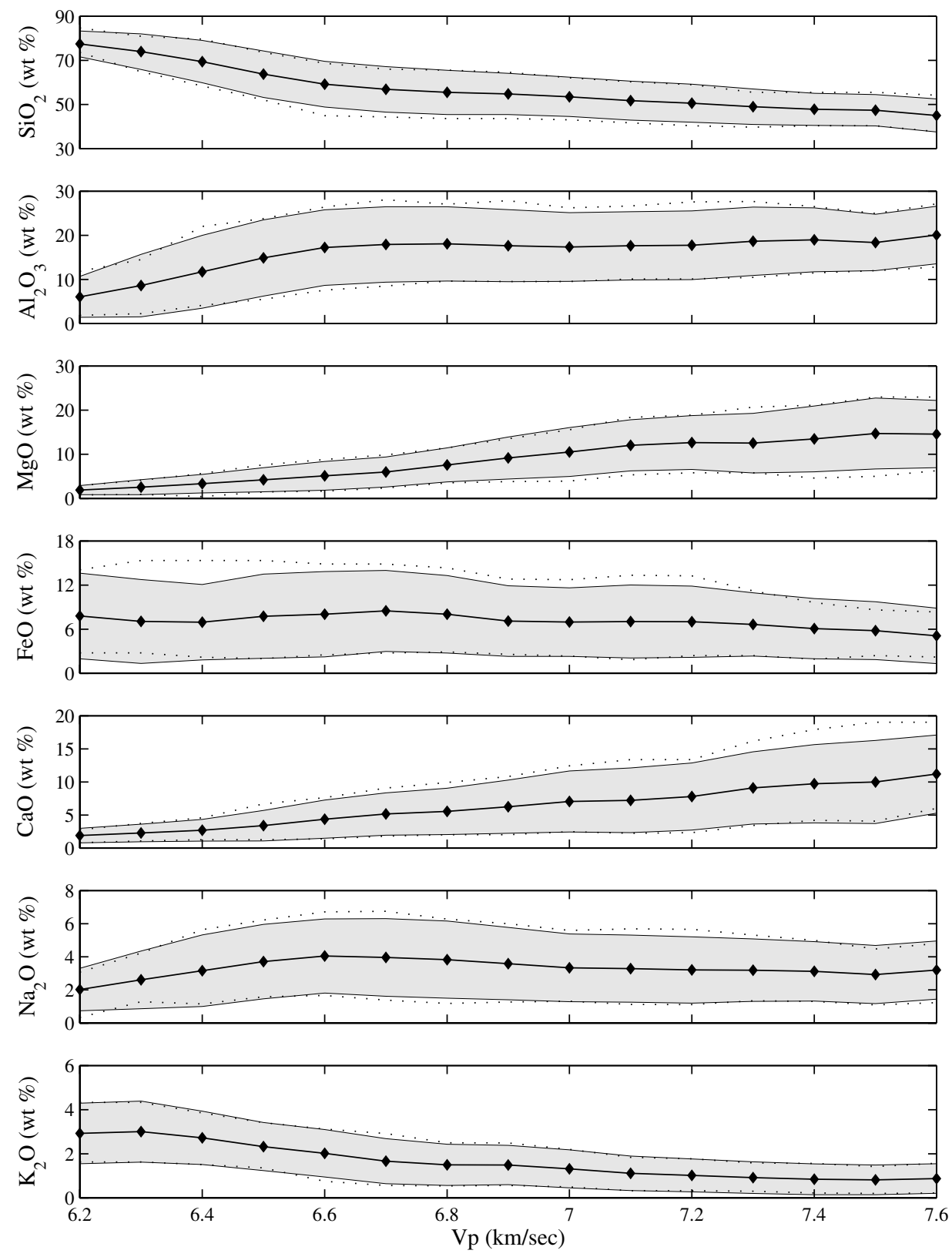

Figure 9. Composition bounds for major element oxides as a function of $V_{p}$ for a depth of $30 \mathrm{~km}$ along a normal crustal geotherm. Mean oxide values are denoted by solid diamonds and grey fields represent $1 \sigma$ variation around the mean. Dotted lines illustrate $67 \%$ confidence intervals. Values are taken from Table A.1.

and orthopyroxene have similar P-wave velocities but vary in their $\mathrm{MgO}$ and $\mathrm{CaO}$ content, as do olivine and garnet).

[30] Another important change in major element chemistry occurs at low velocities $\left(6.3<V_{p}<6.6\right.$ $\mathrm{km} / \mathrm{s}$ ), where mean $\mathrm{SiO}_{2}$ and $\mathrm{K}_{2} \mathrm{O}$ content decrease and $\mathrm{Al}_{2} \mathrm{O}_{3}$ and $\mathrm{Na}_{2} \mathrm{O}$ content increase with higher velocity. These variations are associated with the transition from granite- to diorite-dominated lithologies, in which quartz $\left(V_{p} \approx 6.0 \mathrm{~km} / \mathrm{s}\right)$ and alkali feldspar $\left(\mathrm{Or}_{54}, V_{p} \approx 5.9 \mathrm{~km} / \mathrm{s}\right)$ are replaced by plagioclase $\left(\mathrm{An}_{53}, V_{p} \approx 6.6 \mathrm{~km} / \mathrm{s}\right)$ (see Figure 10$)$. The abruptness of these compositional changes is significant because it indicates that for velocities between 6.3 and $6.6 \mathrm{~km} / \mathrm{s}$, seismic observations can be used to place relatively tight bounds on bulk composition. 


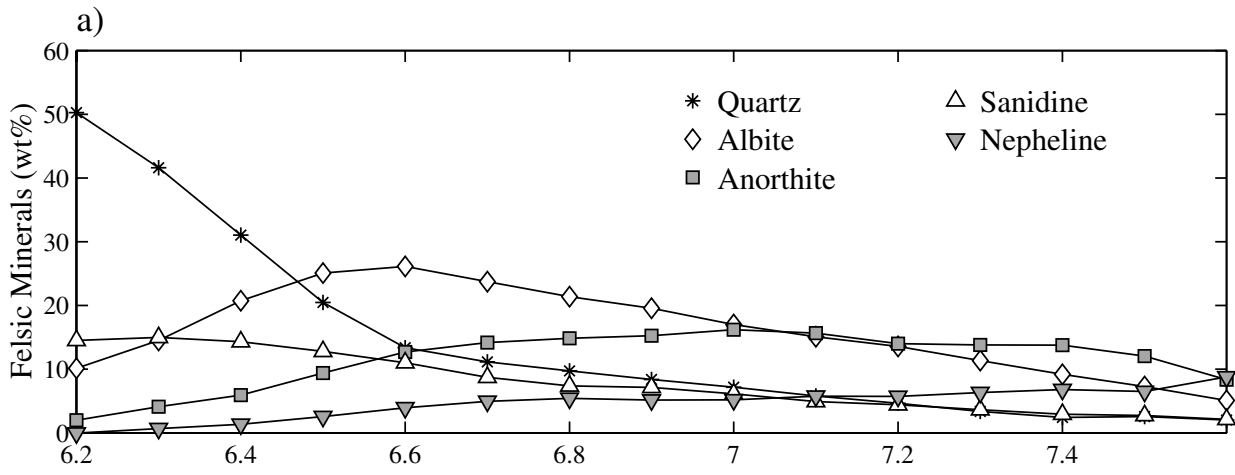

b)

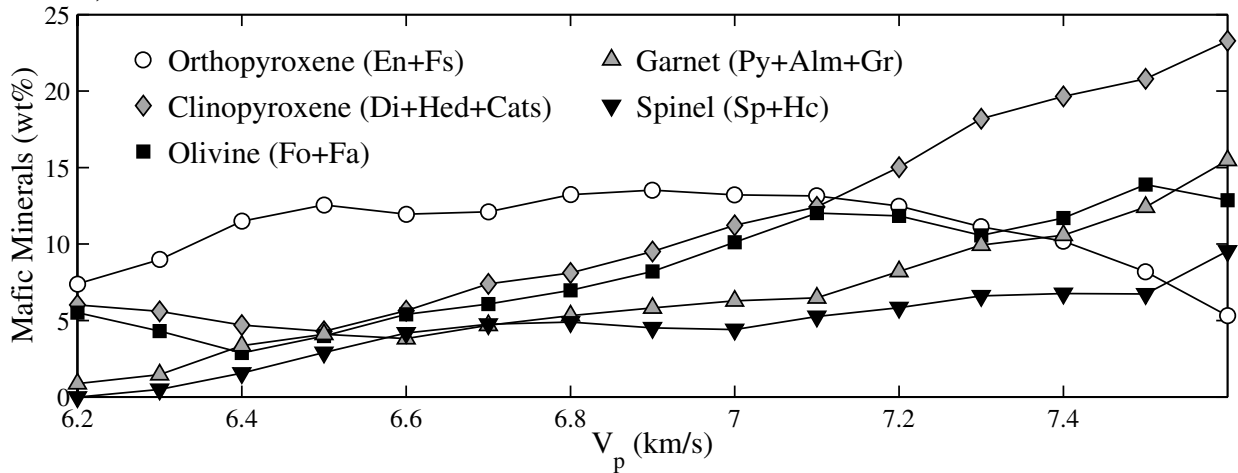

Figure 10. Mean weight percent of major (a) felsic and (b) mafic mineral phases as a function of $V_{p}$ for a depth of $30 \mathrm{~km}$ along a normal crustal geotherm.

[31] As discussed earlier the formation of garnet and jadeite at high pressure significantly complicates the relationship between $V_{p}$ and bulk composition. To assess the importance of these two phases on the inversion of bulk composition from $V_{p}$, we calculated the mean and standard deviation of the major element oxides in each velocity bin along a normal crustal goetherm for $P_{e q}<12 \mathrm{kbar}$ and $P_{e q} \geq 12$ kbar (Tables A.4 and A.5, respectively). The enhanced stability of garnet and jadeite at high pressure causes the inversion with $P_{e q} \geq 12 \mathrm{kbar}$ to predict more siliceous compositions for a given $V_{p}$ than does the inversion with $P_{e q}<12$ kbar. For example, for $V_{p}=7.4 \mathrm{~km} / \mathrm{s}$ at $\mathrm{z}=40 \mathrm{~km}$, the high pressure inversion yields a mean $\mathrm{SiO}_{2}$ content of $51.7 \mathrm{wt} \%$ while the mean $\mathrm{SiO}_{2}$ content calculated from the low pressure inversion is $46.0 \mathrm{wt} \%$. Moreover, because garnet and jadeite tend not to form at low pressure, the standard deviations in the major element oxide distributions are also reduced for the inversion with $P_{e q}<12$ kbar. Thus, in circumstances in which additional constraints can be placed on the pressure of equilibration, it may be possible to further tighten the compositional bounds corresponding to a particular $V_{p}$.

\section{Discussion}

[32] Applying the relationships developed in the previous section to seismic data from a number of tectonic regimes, we now discuss the implications for the composition of the middle and lower continental and oceanic crust.

\subsection{Middle and Lower Continental Crust}

[33] Figure 11 illustrates average crustal velocity sections for a number of continental environments, including Precambrian shields and platforms, orogenic belts, active rifts, continental and island arcs, and rifted margins. These type sections are based on the compilation of Rudnick and Fountain [1995] and are supplemented with several recent studies from arcs [Suyehiro et al., 1996; Morozov et al., 1998; Fliedner and Klemperer, 1999; Hol- 


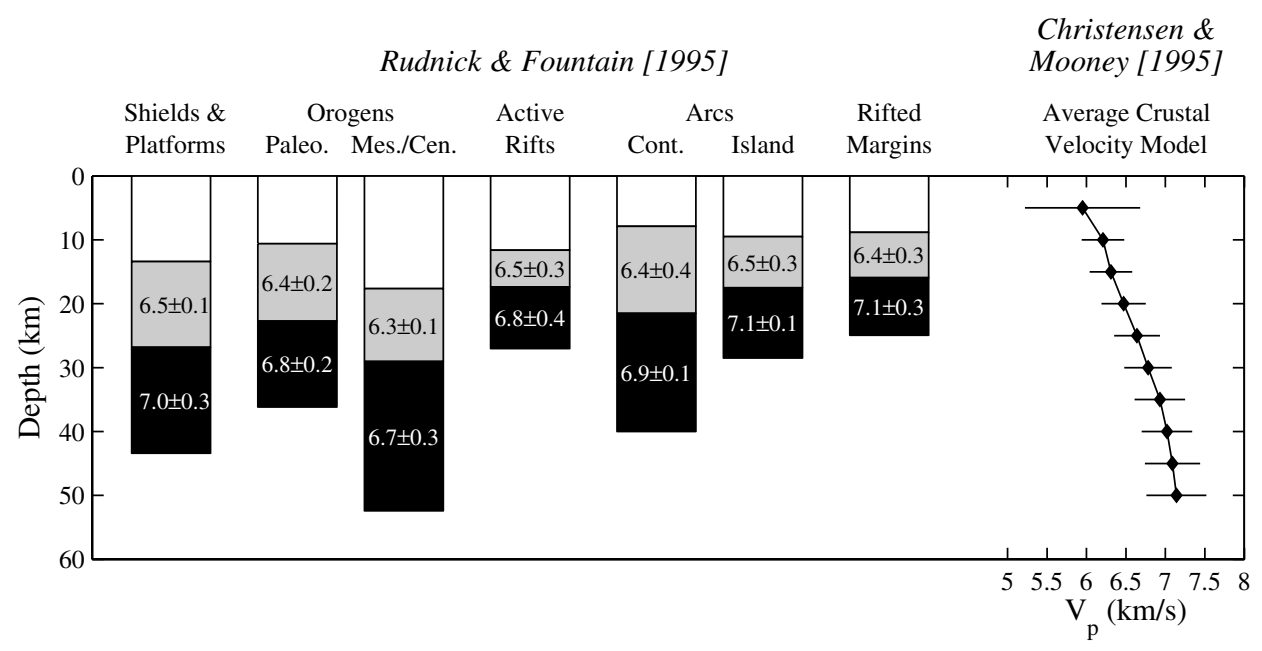

Figure 11. Typical crustal velocity sections for a number of continental environments based on the compilation of Rudnick and Fountain [1995] and supplemented with several recent studies from arcs [Suyehiro et al., 1996; Morozov et al., 1998; Fliedner and Klemperer, 1999; Holbrook et al., 1999; Fliedner and Klemperer, 2000] and rifted margins [Korenaga et al., 2000; Holbrook et al., 2001]. Variability represents the standard deviation of values from all studies in each environment and is similar to the uncertainty in $V_{p}$ estimates for the lower crust in each study. Also shown is the average crustal velocity model of Christensen and Mooney [1995].

brook et al., 1999; Fliedner and Klemperer, 2000], and rifted margins [Korenaga et al., 2000; Holbrook et al., 2001]. Also shown for comparison is the average crustal velocity model of Christensen and Mooney [1995], which represents a global average of all continental environments. In general, velocities in the midcrust $(15-30 \mathrm{~km})$ average $\sim 6.4 \mathrm{~km} / \mathrm{s}$, while lower crustal $(\geq 35 \mathrm{~km})$ velocities range from 6.8 to $7.1 \mathrm{~km} / \mathrm{s}$. Using these models we now calculate constraints on the composition space of the middle and lower continental crust and compare these bounds to previous estimates of crustal composition.

[34] The average bulk composition of the middle and lower continental crust has been estimated using a variety of techniques, including the chemical composition of exposed granulite terranes [Shaw et al., 1986; Rudnick and Presper, 1990], xenoliths from volcanic and kimberlite eruptions [Dupuy et al., 1979; Kay and Kay, 1981; Rudnick and Presper, 1990], heat flow [Taylor and McLennan, 1985; McLennan and Taylor, 1996] and seismic data [Smithson, 1978; Christensen and Mooney, 1995; Rudnick and Fountain, 1995; Wedepohl, 1995; Gao et al., 1998]. Several of these estimates are listed in Table 5, along with corresponding $V_{p}$ values calculated from the major element oxides using equation (4). The calculated velocities range from $6.6-7.1 \mathrm{~km} / \mathrm{s}$ and are in good agreement with the observed velocities for the middle and lower continental crust (Figure 11).

[35] Using the average crustal velocity model of Christensen and Mooney [1995] we calculated compositional bounds for each major element oxide as a function of depth (Table 6), following a procedure similar to that used to generate Tables A.1-A.3. A normal geotherm is assumed and the synthetic composition space is searched at each depth interval in a $V_{p}$ bin defined by the Christensen and Mooney [1995] model. The resulting composition space for the middle and lower continental crust is large, and most of the compositional estimates in Table 5 fall well within the permissible limits. This is important because recent studies by Christensen and Mooney [1995] and Rudnick and Fountain [1995] suggest that only a basaltic lower crustal composition (e.g., RP90x in Table 5) is consistent with the "high" lower crustal $V_{p}$ in the Christensen and Mooney [1995] average crustal velocity model. However, the results of this analysis show that a more felsic composition is not excluded based on P-wave velocities alone.

[36] Although the compositional bounds associated with a specific $V_{p}$ are large, there is significant 
Table 5. Compositional Estimates for the Middle and Lower Continental, Arc, and Rifted Margin Crust ${ }^{\mathrm{a}}$

\begin{tabular}{|c|c|c|c|c|c|c|c|c|c|c|c|c|}
\hline & \multicolumn{9}{|c|}{ Middle and Lower Continental } & \multicolumn{2}{|c|}{ Arc } & \multirow{2}{*}{$\frac{\text { Volcanic Margin }}{\text { B94 }}$} \\
\hline & D79 & WT84 & TM85 & S86 & RP90at & RP90x & W95 & RF95m & RF951 & $\mathrm{B} 83$ & DS91 & \\
\hline $\mathrm{SiO}_{2}$ & 56.3 & 61.2 & 54.4 & 61.5 & 63.3 & 50.5 & 60.0 & 60.6 & 52.3 & 45.7 & 43.8 & 48.5 \\
\hline $\mathrm{TiO}_{2}$ & 1.1 & 0.5 & 1.0 & 0.8 & 0.6 & 1.0 & 0.8 & 0.7 & 0.8 & 0.9 & 0.7 & 0.6 \\
\hline $\mathrm{Al}_{2} \mathrm{O}_{3}$ & 17.1 & 15.6 & 16.1 & 14.9 & 14.6 & 16.5 & 15.3 & 15.5 & 16.6 & 19.3 & 18.7 & 15.9 \\
\hline $\mathrm{FeO}$ & 7.9 & 5.3 & 10.6 & 7.2 & 5.6 & 9.0 & 7.0 & 6.4 & 8.4 & 11.5 & 10.2 & 5.1 \\
\hline $\mathrm{MnO}$ & 0.1 & 0.1 & - & 0.1 & 0.1 & 0.2 & 0.1 & 0.1 & 0.1 & 0.2 & 0.2 & 0.1 \\
\hline $\mathrm{MgO}$ & 5.0 & 3.4 & 6.3 & 4.1 & 3.5 & 7.7 & 4.6 & 3.4 & 7.1 & 7.7 & 10.6 & 12.5 \\
\hline $\mathrm{CaO}$ & 5.5 & 5.6 & 8.5 & 5.2 & 5.1 & 9.8 & 6.1 & 5.1 & 9.4 & 12.9 & 14.0 & 16.6 \\
\hline $\mathrm{Na}_{2} \mathrm{O}$ & 2.1 & 4.4 & 2.8 & 3.1 & 3.4 & 2.4 & 3.0 & 3.2 & 2.6 & 1.7 & 1.7 & 0.5 \\
\hline $\mathrm{K}_{2} \mathrm{O}$ & 1.4 & 1.0 & 0.3 & 1.6 & 2.2 & 0.8 & 1.8 & 2.0 & 0.6 & 0.1 & 0.1 & 0.1 \\
\hline $\mathrm{P}_{2} \mathrm{O}_{5}$ & 0.2 & 0.2 & - & 0.1 & 0.2 & 0.2 & 0.2 & 0.1 & 0.1 & 7.2 & 0.1 & - \\
\hline$V_{p}(\mathrm{~km} / \mathrm{s})$ & 6.7 & 6.6 & 6.9 & 6.6 & 6.6 & 7.1 & 6.8 & 6.6 & 7.0 & 7.3 & 7.4 & 7.6 \\
\hline$\rho\left(\mathrm{g} / \mathrm{cm}^{3}\right)$ & 2.96 & 2.79 & 3.09 & 2.89 & 2.81 & 3.10 & 2.89 & 2.86 & 3.06 & 3.39 & 3.40 & 3.21 \\
\hline
\end{tabular}

${ }^{a} V_{p}$ is calculated from the major element oxides using equation (4) (valid for $P_{r e f}$ and $T_{r e f}$ conditions along a normal crustal geotherm in the depth range $5-50 \mathrm{~km}$ and $P_{e q} \leq 12 \mathrm{kbar}$ ). Densities are estimated from equilibrium mineral assemblages calculated at $P_{\text {ref }}=10 \mathrm{kbar}$ and $T_{r e f}=800^{\circ} \mathrm{C}$. Note that the volcanic margin composition, B94, is an estimated cumulate gabbro composition. Abbreviations are D79 [Dupuy et al., 1979 ], WT84 [Weaver and Tarney, 1984], TM85 [Taylor and McLennan, 1985], S86 [Shaw et al., 1986], RP90at (Archean terranes [Rudnick and Presper, 1990]), RP90x (Xenoliths [Rudnick and Presper, 1990]), W95 [Wedepohl, 1995], RF95m (middle crust [Rudnick and Fountain, 1995]), RF951 (lower crust [Rudnick and Fountain, 1995]), B83 [Burns, 1983], DS91 [DeBari and Sleep, 1991], and B94 [Bernstein, 1994].

covariation within the major element oxides. Thus, in situations where compositional as well as seismic constraints can be placed on the synthetic data space, the range of permissible bulk compositions can be reduced. To illustrate this point, we take the average $V_{p}$ between 20 and $40 \mathrm{~km}$ from the Christensen and Mooney [1995] model and calculate three cases in which $\mathrm{SiO}_{2}$ content is limited to be greater than $60 \%\left(\mathrm{HiSiO}_{2}\right)$, between $50 \%$ and
$60 \%\left(\mathrm{MidSiO}_{2}\right)$, and less than $50 \%\left(\mathrm{LowSiO}_{2}\right)$. The resulting compositional bounds are given at the bottom of Table 6 and frequency distributions of the major element oxides for the $\mathrm{HiSiO}_{2}$ and $\mathrm{Low}$ $\mathrm{SiO}_{2}$ cases are shown in Figure 12. In addition to $\mathrm{SiO}_{2}$, significant differences are observed in the compositional bounds for both $\mathrm{Al}_{2} \mathrm{O}_{3}$ and $\mathrm{Na}_{2} \mathrm{O}$ between the three examples. The $\mathrm{HiSiO}_{2}$ composition is a high Mg-number andesite to dacite com-

Table 6. Compositional Bounds for Major Element Oxides Calculated as a Function of Depth From the Average Crustal Velocity Model of Christensen and Mooney [1995] ${ }^{\mathrm{a}}$

\begin{tabular}{|c|c|c|c|c|c|c|c|c|c|}
\hline $\begin{array}{l}\text { Depth, } \\
\text { km }\end{array}$ & $\begin{array}{c}\text { CM95 } V_{p}, \\
\mathrm{~km} / \mathrm{s}\end{array}$ & $\begin{array}{l}\mathrm{SiO}_{2}, \\
\text { wt \% } \\
\text { oxide }\end{array}$ & $\begin{array}{c}\mathrm{Al}_{2} \mathrm{O}_{3}, \\
\text { wt \% } \\
\text { oxide }\end{array}$ & $\begin{array}{l}\mathrm{MgO} \text {, } \\
\text { wt \% } \\
\text { oxide }\end{array}$ & $\begin{array}{c}\mathrm{FeO}^{*}, \\
\text { wt \% } \\
\text { oxide }\end{array}$ & $\begin{array}{l}\mathrm{CaO} \text {, } \\
\text { wt } \% \\
\text { oxide }\end{array}$ & $\begin{array}{c}\mathrm{Na}_{2} \mathrm{O} \\
\text { wt } \% \\
\text { oxide }\end{array}$ & $\begin{array}{l}\mathrm{K}_{2} \mathrm{O} \text {, } \\
\text { wt \% } \\
\text { oxide }\end{array}$ & $\begin{array}{l}\text { Density, } \\
\mathrm{g} / \mathrm{cm}^{3}\end{array}$ \\
\hline 10 & $21 \pm 0.27$ & $61.4-79.6$ & $3.8-19.4$ & & $2.2-14.4$ & $1.1-4.5$ & $1.2-5.4$ & $1.6-3.9$ & 2.77 \\
\hline 15 & $1 \pm$ & $57.5-$ & 9 & $1.3-6.5$ & 9 & $1.2-5.9$ & $1.3-5.7$ & $1.4-$ & 2.98 \\
\hline 20 & $7 \pm 0.28$ & $48.3-73.8$ & $5.7-25.6$ & $1.5-8.8$ & $7-14.9$ & $1.4-7.3$ & $1.6-6.4$ & $0.9-3.4$ & $2.83-3.01$ \\
\hline 25 & $4 \pm 0.29$ & $46.2-6$ & $7.6-26.3$ & 24 & .9 & $1.6-$ & 1. & .0 & -3.04 \\
\hline 30 & $78 \pm 0.30$ & $44.3-6$ & $9.3-2$ & $3.0-$ & 8 & $1.9-1$ & 1. & .7 & $2.90-3.06$ \\
\hline 35 & $6.93 \pm 0.32$ & $430 \quad 637$ & $9.5-27.6$ & & & & & $0.5-$ & -3.10 \\
\hline 40 & $7.02 \pm 0.3$ & 43.0 & & & & $2.3-$ & & & 2.9 \\
\hline 45 & & & & & & & & & \\
\hline 50 & 7 & $42.3-61.9$ & 6 & 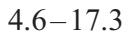 & 1 & 2. & 1. & 0.4 & 2.9 \\
\hline Ave., $20-40$ km & $6.77 \pm 0.30$ & $45.7-$ & $7.6-26.4$ & $2.4-10.8$ & $2.7-14.9$ & $1.5-8.70$ & $1.4-6.4$ & $0.6-3.0$ & $2.86-3.03$ \\
\hline $\mathrm{HiSiO}_{2}$ & 6 & 5 & & & & & & & 3.04 \\
\hline $\mathrm{MidSiO}_{2}$ & $6.77 \pm 0.30$ & $52.1-58.5$ & $13.1-22.5$ & $2.4-13.1$ & $3.0-13.3$ & $2.3-10.2$ & $2.7-5.1$ & $0.7-2.9$ & $2.89-3.04$ \\
\hline $\mathrm{LowSiO}_{2}$ & $6.77 \pm 0.30$ & $37.8-48.2$ & $22.6-32.2$ & $2.4-12.9$ & $4.1-16.4$ & $1.4-8.6$ & $5.1-7.7$ & $0.4-2.1$ & $2.93-3.09$ \\
\hline
\end{tabular}

\footnotetext{
${ }^{a}$ Also given are the compositional bounds for the average crustal velocity in the depth range from $20-40 \mathrm{~km}$. $\mathrm{HiSiO}_{2}, \mathrm{MidSiO}_{2}$, and $\mathrm{LowSiO}_{2}$ represent the composition spaces defined by average crustal velocity when simultaneously constraining $\mathrm{SiO}_{2}$ to be greater than $60 \%$, between $50 \%$ and $60 \%$, and less than $50 \%$, respectively.
} 
Example: $\mathrm{HiSiO}_{2}$
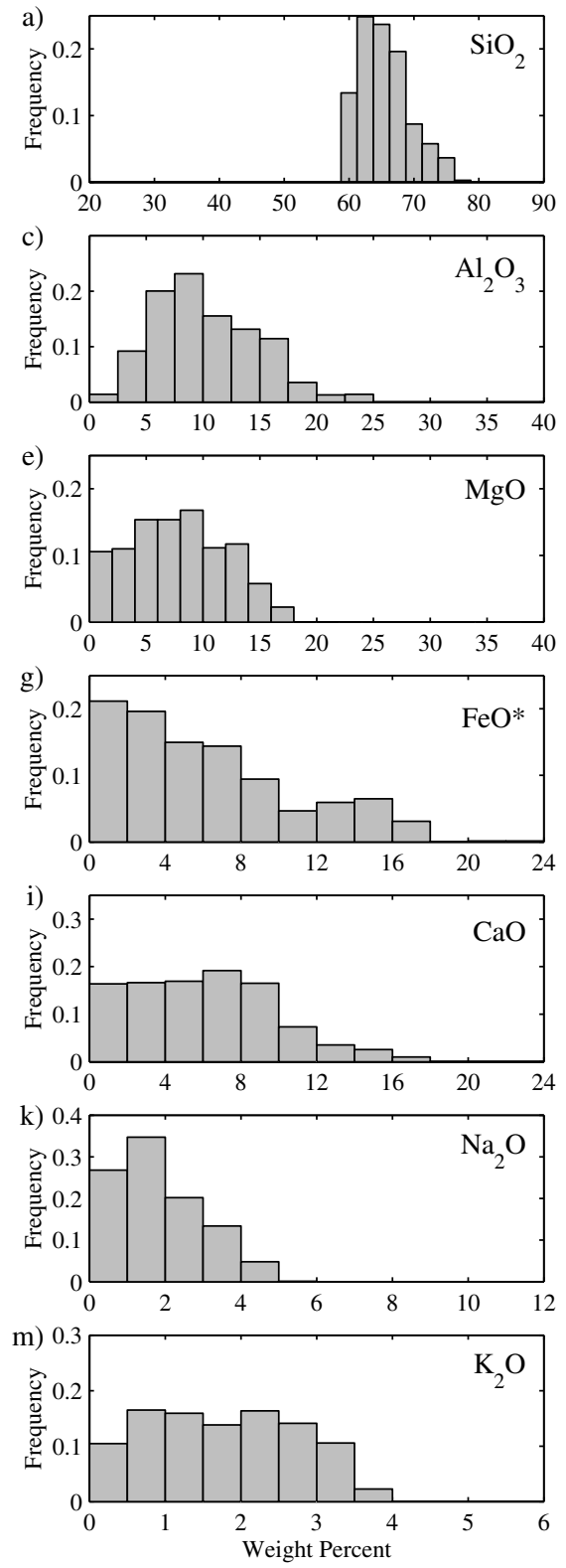

Example: $\mathrm{LowSiO}_{2}$

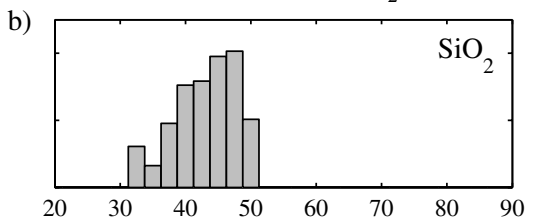

d)

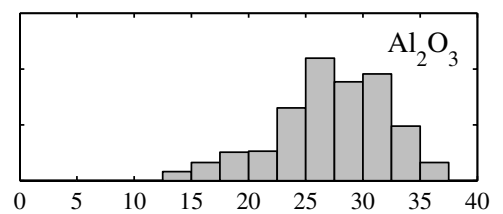

f)

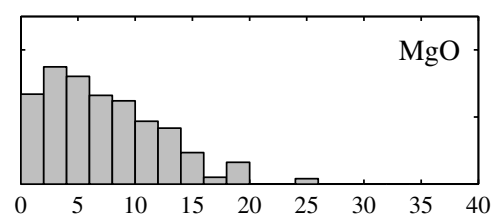

h)
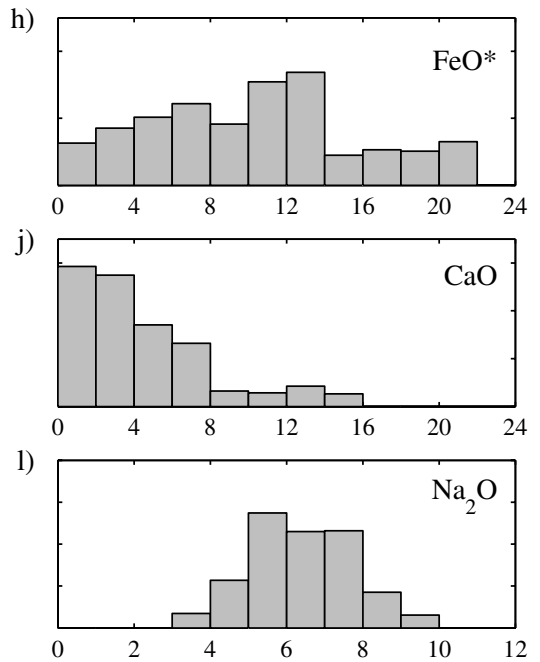

n)

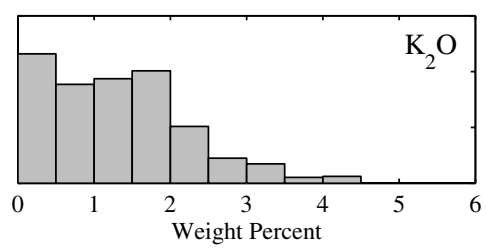

Figure 12. Frequency distributions of the major element oxides for examples $\mathrm{HiSiO}_{2}$ and $\mathrm{LowSiO}_{2}$. Distributions are calculated from the synthetic data by simultaneously constraining $V_{p}$ and $\mathrm{SiO}_{2}$ content. In both cases, $V_{p}$ is constrained using the average crustal velocity between 20 and $40 \mathrm{~km}$ from Christensen and Mooney [1995], while $\mathrm{SiO}_{2}$ content is limited to be $>60 \%$ for $\mathrm{HiSiO}_{2}$ and $<50 \%$ for $\mathrm{LowSiO}_{2}$.

position such as is common in calc-alkaline arc lavas and compositionally similar intermediate plutonic rocks characteristic of batholiths. The $\mathrm{MidSiO}_{2}$ example is very similar to the composition predicted for the average $V_{p}$ with no $\mathrm{SiO}_{2}$ constraint. Finally, the $\mathrm{LowSiO}_{2}$ composition, while somewhat similar to middle and lower crustal compositions observed in island arc sections
(B83, DS91 in Table 5) and anorthositic lower crustal xenoliths [e.g., Rudnick and Jackson, 1995], is an unlikely natural composition due to its extremely high $\mathrm{Al}_{2} \mathrm{O}_{3}$ content and low $\mathrm{CaO}$ content.

[37] To further illustrate how the covariation in the major element oxides can be used to distin- 

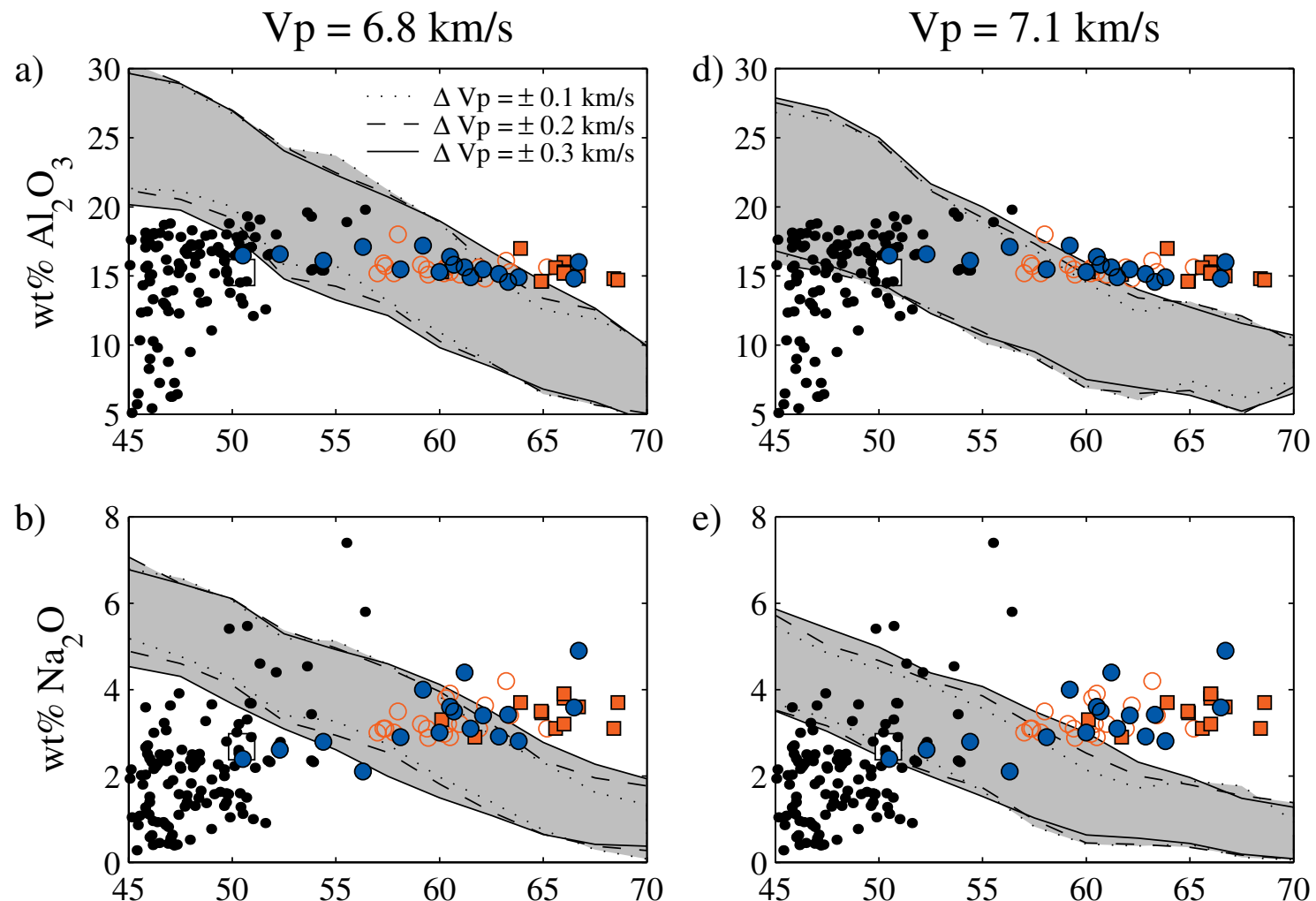

e)
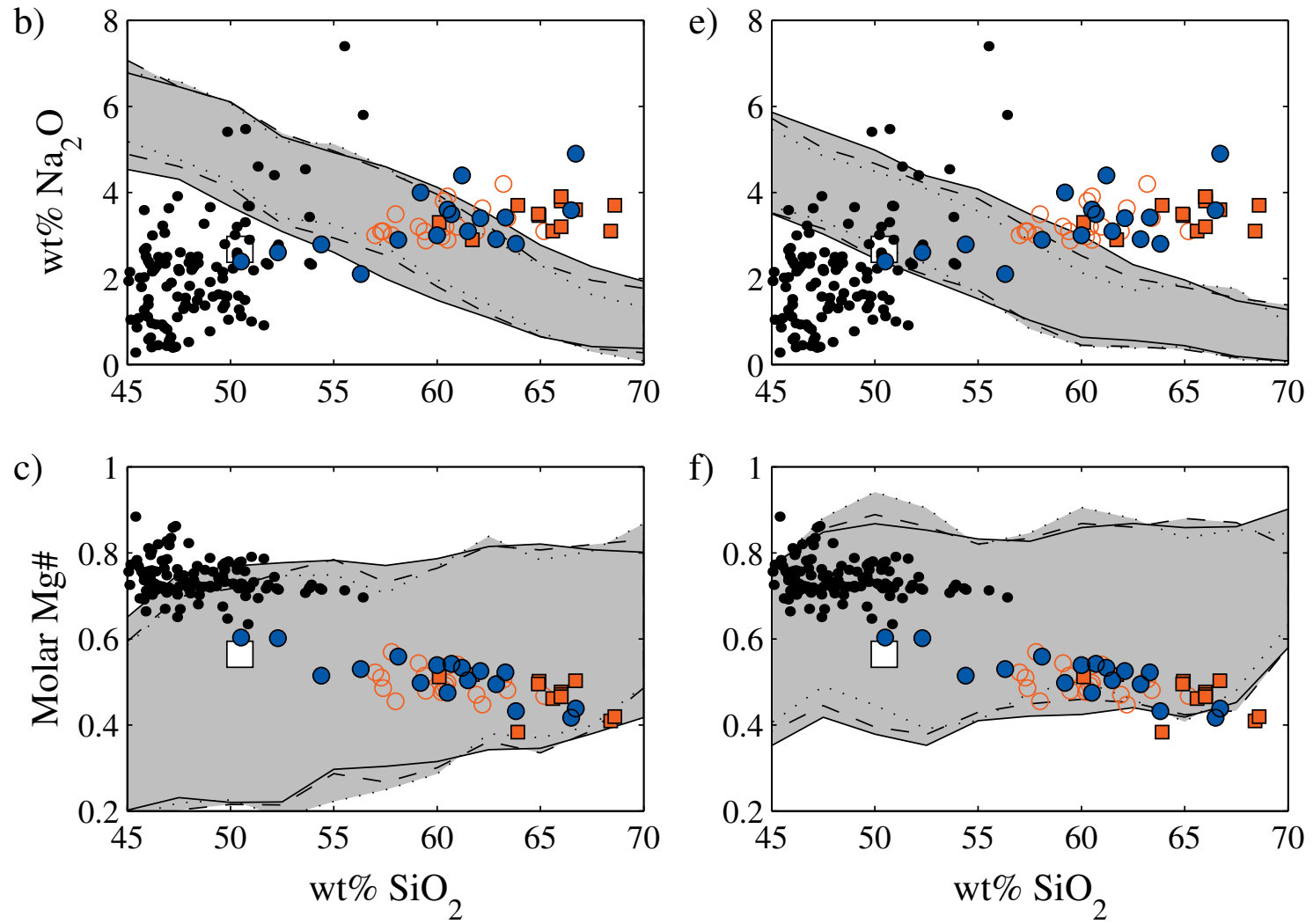

Figure 13. Compositional bounds on (a) $\mathrm{Al}_{2} \mathrm{O}_{3}$, (b) $\mathrm{Na}_{2} \mathrm{O}$, and (c) molar $\mathrm{Mg} \#$ (molar $\mathrm{Mg} /(\mathrm{Mg}+\mathrm{Fe})$ ) as a function of $\mathrm{SiO}_{2}$ when simultaneously constraining $V_{p}$ to be $6.8 \mathrm{~km} / \mathrm{s}$. $V_{p}$ bins of $\pm 0.1 \mathrm{~km} / \mathrm{s}$ (dotted), $\pm 0.2 \mathrm{~km} / \mathrm{s}$ (dashed), and $\pm 0.3 \mathrm{~km} / \mathrm{s}$ (solid) are shown. $\mathrm{SiO}_{2}$ bin size is $\pm 2.5 \mathrm{wt} \%$. (d)-(f) Compositional bounds when constraining $V_{p}$ to be $7.1 \mathrm{~km} / \mathrm{s}$. Symbols denote previous estimates of bulk continental crust (open red circles), upper continental crust (red squares), lower continental crust (blue squares), N-MORB (grey square), and primary melts of mantle peridotite (black dots). Note that the difference between the compositional bounds for $V_{p}=6.8 \mathrm{~km} / \mathrm{s}$ and $V_{p}=7.1 \mathrm{~km} / \mathrm{s}$ are sufficient to distinguish between end-member compositional estimates for the lower continental crust.

guish between estimates for the composition of the middle and lower crust, we calculate bounds on $\mathrm{Al}_{2} \mathrm{O}_{3}, \mathrm{Na}_{2} \mathrm{O}$, and molar $\mathrm{Mg \#}$ while jointly constraining $\mathrm{SiO}_{2}$ and $V_{p}$ (Figure 13). Specifically, we find that estimates of a dacitic composition for the middle and lower continental crust (e.g.,
WT84, S86, RP90at, W95) are consistent with crustal P-wave velocities of $6.8 \mathrm{~km} / \mathrm{s}$, but inconsistent with a $V_{p}$ of $7.1 \mathrm{~km} / \mathrm{s}$ or more. In contrast, basaltic compositions (e.g., RP90x, RP95) are consistent with $V_{p}$ of $7.1 \mathrm{~km} / \mathrm{s}$, but not for a $V_{p}$ of $6.8 \mathrm{~km} / \mathrm{s}$ or less. 
Table 7. Compositional Estimates for the Lower Oceanic Crust From Gabbros in Exposed Ophiolite Sequences, Drill Cores, and Dredged Samples ${ }^{\mathrm{a}}$

\begin{tabular}{|c|c|c|c|c|c|c|c|}
\hline & \multicolumn{3}{|c|}{ Ophiolite } & \multicolumn{3}{|c|}{ Drill Core } & \multirow{2}{*}{$\frac{\text { Dredge }}{\text { H85 }}$} \\
\hline & B82 & P84 & KGunpub & MARK & Hess & $735 \mathrm{~B}$ & \\
\hline $\mathrm{SiO}_{2}$ & 52.0 & 51.1 & 48.4 & 49.5 & 50.2 & 50.6 & 50.2 \\
\hline $\mathrm{TiO}_{2}$ & 0.6 & 0.6 & 0.3 & 0.7 & 0.7 & 0.9 & 0.3 \\
\hline $\mathrm{Al}_{2} \mathrm{O}_{3}$ & 13.5 & 16.6 & 18.4 & 17.8 & 15.2 & 16.1 & 16.2 \\
\hline $\mathrm{FeO}$ & 7.2 & 7.2 & 5.2 & 6.3 & 9.1 & 7.3 & 5.7 \\
\hline $\mathrm{MnO}$ & 0.1 & 0.1 & 0.1 & 0.1 & 0.2 & 0.1 & 0.1 \\
\hline $\mathrm{MgO}$ & 13.5 & 9.2 & 10.3 & 9.8 & 9.2 & 9.2 & 10.0 \\
\hline $\mathrm{CaO}$ & 10.9 & 12.8 & 15.8 & 12.3 & 12.1 & 12.5 & 14.0 \\
\hline $\mathrm{Na}_{2} \mathrm{O}$ & 2.2 & 2.3 & 1.4 & 2.5 & 2.3 & 2.8 & 1.7 \\
\hline $\mathrm{K}_{2} \mathrm{O}$ & 0.1 & 0.1 & 0.0 & 0.0 & 0.1 & 0.1 & 0.1 \\
\hline $\mathrm{P}_{2} \mathrm{O}_{5}$ & 0.0 & 0.1 & 0.0 & 0.1 & 0.1 & 0.1 & 0.0 \\
\hline$V_{p}(\mathrm{~km} / \mathrm{s})$ (equation (4)) & 7.3 & 7.2 & 7.5 & 7.3 & 7.2 & 7.2 & 7.3 \\
\hline$V_{p}(\mathrm{~km} / \mathrm{s})($ Warm $)$ & 7.2 & 7.2 & 7.4 & 7.2 & 7.2 & 7.2 & 7.3 \\
\hline
\end{tabular}

${ }^{\mathrm{a}} V_{p}$ is calculated from the major element oxides using equation (4) and the regression coefficients derived for a warm geotherm (Table 3 ). Abbreviations are B82 [Browning, 1982], P84 [Pallister, 1984], KGunpub (Kelemen and Garrido, unpublished data from Wadi Tayin massif, Oman ophiolite), MARK (ODP Leg 153 [Casey, 1997]), Hess (ODP Leg 147 [Pederson et al., 1996; Miller et al., 1996], plus 3 dredge samples from Hekinian et al. [1993]), 735B (ODP Leg 176 [Dick et al., 2000]), and H85 [Hyndman, 1985].

[38] Seismic inferences of composition can also provide meaningful results when seismic data are used to evaluate compositional variations between individual locations or differences relative to a specific reference model. For example, middle and lower crustal velocities along the western North Atlantic margin are observed to vary from $6.7 \mathrm{~km} / \mathrm{s}$ near the Grand Banks, Newfoundland [Reid, 1994] to $7.5 \mathrm{~km} / \mathrm{s}$ offshore of Virginia [Holbrook et al., 1994]. These variations have been interpreted to reflect spatial variations in the composition of the middle and lower margin crust and the evolution of the continental margin. To the north, the middle and lower crust is assumed to consist primarily of remnant continental material of granitic composition [e.g., Tucholke et al., 1989]. In contrast, the higher velocities observed along the mid-Atlantic margin are typically associated with basaltic and gabbroic compositions formed by synrift volcanism and igneous "underplating" [e.g., LASE Study Group, 1986; Tréhu et al., 1989; Holbrook and Kelemen, 1993].

[39] Using the compositional bounds in Table A.1 we assess the differences in composition associated with a change in $V_{p}$ from 6.7 to $7.5 \mathrm{~km} / \mathrm{s}$ at a depth of $20 \mathrm{~km}$. Although the $1 \sigma$ bounds are sufficiently wide that the compositional range for each major element oxide cannot be formally distinguished, the calculated composition spaces are quite differ- ent. For example, the range in $\mathrm{SiO}_{2}$ content calculated for $V_{p}=6.7 \mathrm{~km} / \mathrm{s}$ is $57 \pm 10 \%$, while for $V_{p}=$ $7.5 \mathrm{~km} / \mathrm{s}$ the range is $47 \pm 7 \%$. Similiarly, the range in $\mathrm{MgO}$ content is found to be $6 \pm 4 \%$ for $V_{p}=$ $6.7 \mathrm{~km} / \mathrm{s}$ and $15 \pm 8 \%$ for $V_{p}=7.5 \mathrm{~km} / \mathrm{s}$. Comparing these compositional bounds to the estimates of middle and lower crustal composition presented in Table 5, we see that a $V_{p}$ of $7.5 \mathrm{~km} / \mathrm{s}$ is inconsistent with most estimates for the middle and lower continental crust (except RP90x and RF95) and is most consistent with a cumulate gabbro composition (B94). In contrast, the calculated $\mathrm{MgO}, \mathrm{CaO}$, and $\mathrm{Na}_{2} \mathrm{O}$ content for $V_{p}=6.7 \mathrm{~km} / \mathrm{s}$ are not consistent with a cumulate gabbro and resemble more felsic compositions.

\subsection{Lower Oceanic Crust}

[40] We now examine the implications of this study for the lower oceanic crust. The classic model for the composition of oceanic crust is based on the joint interpretation of ophiolite sequences and seismic observations at modern oceanic spreading centers. In this model the lower oceanic crust is composed of a $4-5.5 \mathrm{~km}$ thick section of massive and cumulate gabbros. This section, often referred to in seismic studies as oceanic layer 3 , is characterized by a low velocity gradient with depth and an average $V_{p}$ of $6.9-$ 7.0 km/s [Raitt, 1963; Shor et al., 1970; Chris- 


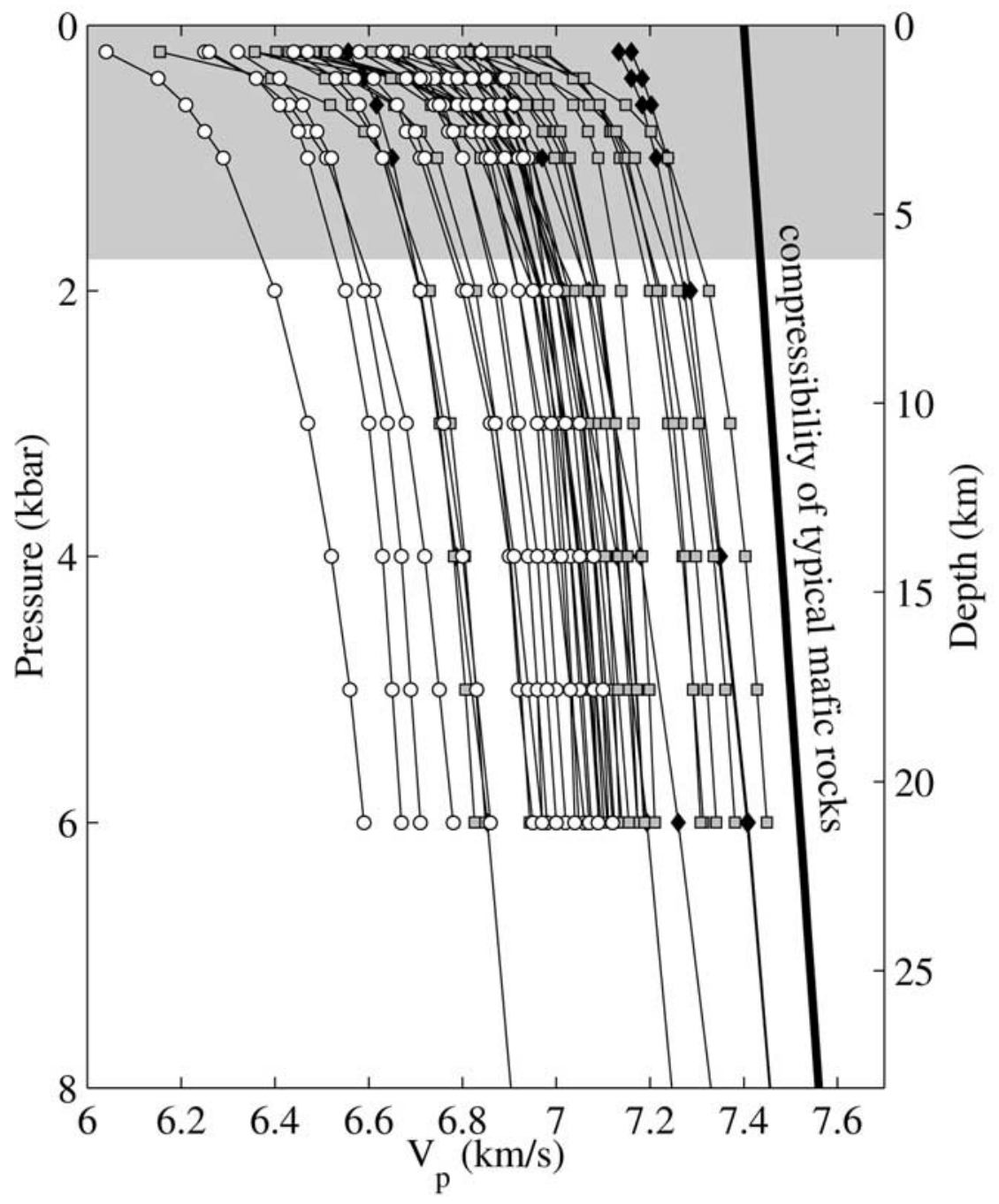

Figure 14. Laboratory measurements of $V_{p}$ as a function of confining pressure in gabbros taken from ODP Leg 147, Hess Deep (circles) [Iturrino et al., 1996], ODP Leg 153, MARK Area (squares) [Miller and Christensen, 1997], and ophiolite exposures in the western United States (diamonds) [Christensen, 1978]. All measurements were made at room temperature. Thick solid line illustrates a typical pressure derivative for mafic rocks due to the effect of pressure on the elastic moduli of major mineral phases [Rudnick and Fountain, 1995]. Note that at confining pressures appropriate for the oceanic crust (grey region) the change in $V_{p}$ with pressure is significantly greater than that predicted from the mineral compressibilities alone.

tensen and Salisbury, 1975; White et al., 1992]. Deviations from this mean value, specifically, the observation of relatively high $V_{p}$ lower crust in thick igneous crust along "volcanic rifted margins", have typically been interpreted to reflect anomalous crustal compositions formed in the presence of elevated mantle temperatures [e.g., White and McKenzie, 1989; Kelemen and Holbrook, 1995]. Using the melting model of McKenzie and Bickle [1988], White and McKenzie [1989] found that if normal oceanic crust is assumed to form from a mantle potential temperature of $1280^{\circ} \mathrm{C}$, then a potential temperature of $1580^{\circ} \mathrm{C}$ is required to generate crust with velocities of $7.2 \mathrm{~km} / \mathrm{s}$. This result has subsequently been used to infer that the thick sections of highvelocity lower crust $\left(V_{p} \geq 7.2 \mathrm{~km} / \mathrm{s}\right)$ observed at a number of volcanic rifted margins and oceanic plateaus must have formed in the presence of a hot mantle plume [e.g. White and McKenzie, 1989; Kelemen and Holbrook, 1995; Holbrook et al., 2001]. 
[41] Estimates for the average bulk composition of the lower oceanic crust have been made from gabbros in dredged samples [Hyndman, 1985; Hekinian et al., 1993], drill cores [Pederson et al., 1996; Casey, 1997; Dick et al., 2000], and exposed ophiolite sequences [Browning, 1982; Pallister, 1984] (Table 7). Based on these estimates we calculate predicted velocities of 7.2$7.4 \mathrm{~km} / \mathrm{s}$ for the lower oceanic crust. As noted by Korenaga et al. [2002], who used a similar procedure, our calculated velocities are significantly higher than the average observed value for oceanic layer 3 and very similar to lower crustal $V_{p}$ in volcanic rifted margins. Because most seismic velocity measurements in oceanic crust are made at or near the ridge crest, the regression coefficients derived for the warm geotherm (Table 3) were used to simulate thermal conditions in 5-10 Ma oceanic lithosphere [Stein and Stein, 1992]. Had the coefficients for the normal geotherm in equation (4) been used, the predicted velocities would be even higher, by $\sim 0.1 \mathrm{~km} / \mathrm{s}$ (Table 7).

[42] These results are significant because they indicate that in situ measurements of $V_{p}$ at oceanic spreading centers are $0.2-0.3 \mathrm{~km} / \mathrm{s}$ slow compared to the velocities predicted for gabbro. Korenaga et al. [2002] suggested two possible explanations for the slow velocities in oceanic layer 3: (1) alteration associated with hydrothermal circulation and (2) residual crack porosity. Assuming that the effect of hydrothermal alteration can be approximated by replacement of clinopyroxene with hornblende, Korenaga et al. [2002] calculated that even 100\% alteration is unable to reduce $V_{p}$ to $6.9 \mathrm{~km} / \mathrm{s}$ in typical oceanic gabbros. Furthermore, studies of oceanic lower crustal gabbro from dredging, ocean drilling, and ophiolites show that hydrothermal alteration is localized in cracks and veins, and that hydrous minerals compose less than $5 \%$ of the rocks, on average, and less than $10 \%$ of the olivine plus clinopyroxene [e.g., Gregory and Taylor, 1981; Robinson et al., 1989; Dick et al., 2000]. Thus, they favored a model in which the slow velocities in the lower crust are the result of residual porosity. Specifically, Korenaga et al. [2002] noted that if the aspect ratio of pores is low (i.e., crack-shaped), porosities $<1 \%$ can reduce $V_{p}$ to $6.9 \mathrm{~km} / \mathrm{s}$. These estimates of bulk porosity are in agreement with measurements from ODP Hole 735B [Iturrino et al., 1991] and the Continental Deep Drilling Project (KTB) [Huenges et al., 1997], which show porosities of $0.5-1 \%$ down to depths approaching $4 \mathrm{~km}$.

[43] Experimental data for $V_{p}$ in gabbros also support the hypothesis that residual porosity may be the cause of the apparently low velocities in oceanic layer 3 compared to calculated velocities for likely lower crustal gabbro compositions. Figure 14 illustrates $V_{p}$ versus pressure in gabbro samples taken from ODP drill cores at Hess Deep [Iturrino et al., 1996] and the MARK Area [Miller and Christensen, 1997] and ophiolites in the western United States [Christensen, 1978]. For pressures greater than $2 \mathrm{kbar}$, the change in $V_{p}$ with pressure follows closely the predicted value based on the compressibilities of typical mafic minerals. However, from $0-2$ kbar the change in $V_{p}$ with pressure is significantly greater, suggesting that the complete closure of cracks is not achieved at the ambient pressures present in the lower oceanic crust. This conclusion is consistent with earlier experimental studies by Kern and Richter [1981] and Kern and Schenk [1985, 1988] and also with the comparison of the best-fit $V_{p}$ to the laboratory data presented in Figure 6.

[44] A final explanation for the discrepancy between the measured layer 3 velocities and those calculated for likely lower crustal gabbro compositions is that the lower crust might be composed of partially serpentinized mantle peridotites. This model for the lower oceanic crust was originally proposed by Hess [1962, 1965] and Dietz [1963]. A recent study by Carlson and Miller [1997] found that the observed S-wave velocities in the lower crust are more compatible with gabbroic compositions than partially serpentinized peridotites. However, serpentinized peridotites are commonly found in slow-spreading environments. Serpentinite layers, or serpentinized olivine in gabbros, even in small quantities can strongly affect $V_{p}$ [Carlson, 2001]. Thus, serpentinization of peridotite and/or serpentinization of olivine in gabbro may be at 
least partially responsible for the slow observed velocities in the lower oceanic crust.

[45] The observation that the lower oceanic crust is slow relative to the velocity predicted for the bulk composition of gabbro has several important implications. First, it suggests that some observed velocity gradients in layer 3 are associated with changes in pressure and not with a transition toward more mafic cumulate compositions [e.g., Salisbury and Christensen, 1984; Christensen and Smewing, 1981]. Second, as previously noted by Korenaga et al. [2002], if normal oceanic gabbros have velocities of $7.2-7.3 \mathrm{~km} / \mathrm{s}$, then the sections of thick "high" velocity igneous lower crust at many volcanic margins and oceanic plateaus may not reflect anomalous lower crustal composition. Rather, it may be that the increase in ambient pressure at the base of the thickened crust at these margins is sufficient to close all cracks. This would imply that elevated mantle temperatures are not required for the formation of these thick igneous sequences, and that alternative models in which large amounts of melt are fluxed through the solidus in the absence of a thermal anomaly [e.g., Mutter et al., 1988] must be revisited.

\section{Conclusions}

[46] In this study we have presented a method to quantitatively assess the relationship between the composition and P-wave velocity of anhydrous igneous and meta-igneous rocks. Using seismic velocities calculated from equilibrium mineral assemblages for all igneous composition space, we derived a linear function relating $V_{p}$ to major element chemistry that is valid to $\pm 0.13 \mathrm{~km} / \mathrm{s}$ for all pressure and temperature conditions along a normal crustal geotherm in the depth range of 5$50 \mathrm{~km}$ and $P_{e q} \leq 12 \mathrm{kbar}$. We note that the equilibration calculations performed in this study ignore the presence of both $\mathrm{Fe}^{3+}$ and $\mathrm{H}_{2} \mathrm{O}$ and future work is needed to assess the influence of these variables on the relationship between $V_{p}$ and composition.

[47] The calculated mineral assemblages were also used to address the inverse problem, namely what is the full range of igneous compositions that are consistent with a particular P-wave velocity. The resulting compositional bounds for a specific velocity were found to be broad. However, because major oxides are correlated in igneous rocks, joint constraints on $V_{p}$ and individual oxides can narrow the possible range of acceptable crustal compositions. For example, in the case of the middle and lower continental crust, dacitic compositions are found to be more consistent with velocities $\leq 6.8 \mathrm{~km} / \mathrm{s}$, while basaltic compositions are more consistent with velocities $\geq 7.1 \mathrm{~km} / \mathrm{s}$. In the midcrust, observed velocities support a dacitic composition. However, most estimates of lower crustal $V_{p}$ range from $6.8 \mathrm{~km} / \mathrm{s}$ to $7.1 \mathrm{~km} / \mathrm{s}$ making it very difficult to distinguish between these two compositions. In summary, we conclude that while composition can be used to provide a robust estimate of $V_{p}$, P-wave velocities alone provide only broad constraints on bulk crustal composition. Future work is necessary to determine whether a joint inversion of $V_{p}$ and $V_{s}$ can significantly narrow these compositional constraints.

[48] Finally, based on the forward relationship between $V_{p}$ and major element chemistry derived in this study, we find the observed velocities in the lower oceanic crust to be $0.2-0.3 \mathrm{~km} / \mathrm{s}$ slower than the velocities predicted based on the average bulk composition of gabbros in drill cores and exposed ophiolite sequences. We hypothesize that this discrepancy is caused by a combination of residual porosity at crustal depths less than $\sim 10 \mathrm{~km}$ and the presence of hydrous alteration phases, including partial serpentinization of peridotite and olivine gabbro in the lower crust. If correct, this implies that future studies should use caution when inferring mantle melting parameters from lower crustal velocities at depths shallower than $\sim 10 \mathrm{~km}$.

\section{Acknowledgments}

[49] We thank Jamie Connolly for the generous use of his programs to calculate phase equilibria and Jun Korenaga, Greg Hirth, and Ralph Stevens for insightful discussions. Reviews by Jay Miller, Roberta Rudnick, and an anonymous reviewer significantly improved this study. Jian Lin, Maria Zuber, Bob 
Table A.1. Mean and Standard Deviation of Major Element Oxides as a Function of $V_{p}$ for a Normal Continental Geotherm $\left(q_{s}=56 \mathrm{~mW} \mathrm{~m}^{-2}\right)^{\mathrm{a}}$

\begin{tabular}{|c|c|c|c|c|c|c|c|c|c|c|}
\hline Depth (km) & 5 & 10 & 15 & 20 & 25 & 30 & 35 & 40 & 45 & 50 \\
\hline $\mathrm{T}\left({ }^{\circ} \mathrm{C}\right)$ & 91 & 155 & 211 & 263 & 311 & 359 & 405 & 451 & 496 & 541 \\
\hline P (kbar) & 1.6 & 3.2 & 4.9 & 6.5 & 8.1 & 9.7 & 11.3 & 12.9 & 14.6 & 16.2 \\
\hline \multicolumn{11}{|c|}{$V_{p}=6.2 \mathrm{~km} / \mathrm{s}$} \\
\hline \multicolumn{11}{|l|}{ Mean } \\
\hline $\mathrm{SiO}_{2}$ & 75.9 & 76.3 & 76.3 & 76.7 & 77.0 & 77.5 & 77.3 & 75.9 & 76.6 & 77.0 \\
\hline $\mathrm{Al}_{2} \mathrm{O}_{3}$ & 7.5 & 7.1 & 7.1 & 6.9 & 6.7 & 6.0 & 6.3 & 7.4 & 7.1 & 6.9 \\
\hline $\mathrm{MgO}$ & 2.2 & 2.1 & 2.1 & 2.1 & 2.1 & 1.9 & 1.5 & 1.2 & 1.0 & 0.9 \\
\hline $\mathrm{FeO}$ & 7.2 & 7.3 & 7.3 & 7.4 & 7.4 & 7.8 & 7.9 & 9.4 & 9.3 & 9.1 \\
\hline $\mathrm{CaO}$ & 2.0 & 2.0 & 2.0 & 1.9 & 1.9 & 1.9 & 1.9 & 1.4 & 1.5 & 1.5 \\
\hline $\mathrm{Na}_{2} \mathrm{O}$ & 2.3 & 2.2 & 2.2 & 2.2 & 2.1 & 2.0 & 2.1 & 2.2 & 2.1 & 2.1 \\
\hline $\mathrm{K}_{2} \mathrm{O}$ & 2.9 & 2.9 & 2.9 & 2.9 & 2.9 & 2.9 & 3.0 & 2.4 & 2.4 & 2.4 \\
\hline \multicolumn{11}{|l|}{ Std. Dev. } \\
\hline $\mathrm{SiO}_{2}$ & 6.3 & 6.5 & 6.5 & 6.2 & 6.2 & 5.9 & 6.4 & 6.6 & 7.7 & 7.7 \\
\hline $\mathrm{Al}_{2} \mathrm{O}_{3}$ & 5.3 & 5.3 & 5.3 & 5.1 & 5.0 & 4.6 & 4.9 & 5.4 & 5.6 & 5.6 \\
\hline $\mathrm{MgO}$ & 1.1 & 1.1 & 1.1 & 1.1 & 1.1 & 1.0 & 0.9 & 0.8 & 0.5 & 0.5 \\
\hline $\mathrm{FeO}$ & 5.5 & 5.5 & 5.5 & 5.6 & 5.5 & 5.8 & 6.3 & 6.9 & 7.2 & 6.9 \\
\hline $\mathrm{CaO}$ & 1.1 & 1.1 & 1.1 & 1.1 & 1.1 & 1.1 & 1.2 & 0.8 & 0.8 & 0.8 \\
\hline $\mathrm{Na}_{2} \mathrm{O}$ & 1.4 & 1.4 & 1.4 & 1.4 & 1.4 & 1.3 & 1.3 & 1.5 & 1.6 & 1.6 \\
\hline $\mathrm{K}_{2} \mathrm{O}$ & 1.3 & 1.3 & 1.3 & 1.3 & 1.3 & 1.4 & 1.5 & 1.1 & 1.0 & 1.0 \\
\hline$N$ & 150 & 147 & 146 & 141 & 135 & 107 & 74 & 47 & 34 & 32 \\
\hline \multicolumn{11}{|c|}{$V_{p}=6.3 \mathrm{~km} / \mathrm{s}$} \\
\hline Mean & & & & & & & & & & \\
\hline $\mathrm{SiO}_{2}$ & 73.5 & 73.7 & 73.5 & 73.8 & 73.9 & 73.9 & 74.1 & 74.4 & 75.3 & 75.4 \\
\hline $\mathrm{Al}_{2} \mathrm{O}_{3}$ & 8.7 & 8.8 & 8.7 & 8.4 & 8.4 & 8.6 & 8.5 & 8.5 & 8.0 & 7.9 \\
\hline $\mathrm{MgO}$ & 3.0 & 3.0 & 2.9 & 2.9 & 2.8 & 2.6 & 2.4 & 2.0 & 2.1 & 2.0 \\
\hline $\mathrm{FeO}$ & 6.8 & 6.6 & 7.0 & 7.2 & 7.1 & 7.0 & 7.3 & 7.7 & 7.3 & 7.3 \\
\hline $\mathrm{CaO}$ & 2.6 & 2.5 & 2.5 & 2.3 & 2.3 & 2.3 & 2.2 & 2.1 & 2.0 & 1.9 \\
\hline $\mathrm{Na}_{2} \mathrm{O}$ & 2.5 & 2.5 & 2.5 & 2.5 & 2.5 & 2.6 & 2.6 & 2.5 & 2.5 & 2.5 \\
\hline $\mathrm{K}_{2} \mathrm{O}$ & 2.9 & 2.9 & 2.9 & 2.9 & 3.0 & 3.0 & 2.9 & 2.8 & 2.9 & 3.0 \\
\hline
\end{tabular}

Std. Dev

$\mathrm{Al}_{2} \mathrm{O}_{3}$

$\mathrm{MgO}$

$\mathrm{FeO}$

$\mathrm{CaO}$

$\mathrm{Na}_{2} \mathrm{O}$

$\mathrm{K}_{2} \mathrm{O}$

8.1

N

$\begin{array}{lll}8.1 & 8.1 & 8.2 \\ 7.0 & 7.1 & 7.1 \\ 2.0 & 2.0 & 1.9 \\ 5.2 & 5.2 & 5.7 \\ 1.6 & 1.6 & 1.6 \\ 1.8 & 1.8 & 1.8 \\ 1.3 & 1.3 & 1.3 \\ & & \\ 268 & 264 & 264\end{array}$

$\begin{array}{ll}8.0 & 8.0 \\ 7.0 & 7.1 \\ 1.9 & 1.8 \\ 5.8 & 5.8 \\ 1.4 & 1.4 \\ 1.8 & 1.8 \\ 1.4 & 1.4 \\ & \\ 238 & 225\end{array}$

$8.0 \quad 7.8$
7.1

$\begin{array}{ll}7.1 & 6.5\end{array}$

$\begin{array}{ll}7.1 & 6.5 \\ 1.7 & 1.6\end{array}$

1.7
5.7

5.7
1.3

1.7

1.6
5.8

1.3

1.7

1.7
1.4

207

187

$$
V_{p}=6.4 \mathrm{~km} / \mathrm{s}
$$

\section{Mean}

$\mathrm{SiO}_{2}$

$\mathrm{Al}_{2} \mathrm{O}_{3}$

$\mathrm{MgO}$

$\mathrm{FeO}$

$\mathrm{CaO}$

$\mathrm{Na}_{2} \mathrm{O}$

67.5

67.4

67.4

$67.7 \quad 68.2$

$12.6 \quad 12.9$

13.0

12.9

3.7

3.6

7.1

6.9

6.9

3.1
3.4

$$
3.6
$$

6.8

3.0
3.4

2.6

2.7

12.6

3.5

6.8

2.9

3.4

69.4

11.7

70.4

$3.3 \quad 3.2$

3.2
7.1

6.9

2.7

3.2

2.6

3.0

8.1

8.2

8.3

$\begin{array}{ll}8.6 & 6.7\end{array}$

1.2

5.7

1.1

5.5

1.2

1.7

1.1

1.8

$$
1.1
$$

5.6

1.1

1.8

Std. Dev.

$\mathrm{SiO}_{2}$

$\mathrm{Al}_{2} \mathrm{O}_{3}$

$\mathrm{MgO}$

9.6
8.6
2.6

2.6

2.7

2.7

2.7

71.6

$\begin{array}{ll}72.3 & 72.7\end{array}$

$\begin{array}{lll}10.2 & 9.7 & 9.4\end{array}$

$\begin{array}{lll}3.2 & 3.0 & 3.0\end{array}$

6.7

$\begin{array}{ll}6.9 & 6.8\end{array}$

$\begin{array}{ll}3.3 & 3.3 \\ 2.6 & 2.6\end{array}$

$\mathrm{FeO}$

$\begin{array}{ll}9.7 & 9.8 \\ 8.5 & 8.6 \\ 2.5 & 2.5 \\ 5.2 & 5.1\end{array}$

$\begin{array}{lllllll}9.7 & 9.5 & 9.6 & 9.6 & 9.6 & 9.2 & 9.2 \\ 8.6 & 8.4 & 8.3 & 8.2 & 8.1 & 8.0 & 7.8 \\ 2.5 & 2.3 & 2.1 & 2.0 & 2.0 & 2.0 & 1.9 \\ 5.2 & 5.3 & 5.1 & 5.1 & 5.0 & 5.1 & 5.2\end{array}$


Table A.1. (continued)

\begin{tabular}{|c|c|c|c|c|c|c|c|c|c|c|}
\hline Depth $(\mathrm{km})$ & 5 & 10 & 15 & 20 & 25 & 30 & 35 & 40 & 45 & 50 \\
\hline $\mathrm{T}\left({ }^{\circ} \mathrm{C}\right)$ & 91 & 155 & 211 & 263 & 311 & 359 & 405 & 451 & 496 & 541 \\
\hline P (kbar) & 1.6 & 3.2 & 4.9 & 6.5 & 8.1 & 9.7 & 11.3 & 12.9 & 14.6 & 16.2 \\
\hline $\mathrm{CaO}$ & 2.0 & 2.0 & 1.9 & 1.8 & 1.8 & 1.7 & 1.6 & 1.6 & 1.6 & 1.6 \\
\hline $\mathrm{Na}_{2} \mathrm{O}$ & 2.2 & 2.2 & 2.2 & 2.2 & 2.2 & 2.2 & 2.1 & 2.1 & 2.0 & 2.0 \\
\hline $\mathrm{K}_{2} \mathrm{O}$ & 1.2 & 1.2 & 1.2 & 1.2 & 1.2 & 1.2 & 1.2 & 1.3 & 1.3 & 1.3 \\
\hline$N$ & 290 & 286 & 278 & 269 & 257 & 265 & 291 & 302 & 297 & 274 \\
\hline \multicolumn{11}{|c|}{$V_{p}=6.5 \mathrm{~km} / \mathrm{s}$} \\
\hline $\begin{array}{l}\text { Mean } \\
\mathrm{SiO}_{2}\end{array}$ & 60.9 & 61.4 & 61.7 & 62.3 & 62.9 & 63.7 & 64.6 & 65.4 & 65.6 & 65.7 \\
\hline $\mathrm{Al}_{2} \mathrm{O}_{3}$ & 16.6 & 16.3 & 16.2 & 15.9 & 15.5 & 14.9 & 14.3 & 13.8 & 13.6 & 13.7 \\
\hline $\mathrm{MgO}$ & 4.5 & 4.5 & 4.4 & 4.2 & 4.2 & 4.2 & 4.3 & 4.2 & 4.1 & 3.9 \\
\hline $\mathrm{FeO}$ & 7.8 & 7.8 & 7.8 & 7.7 & 7.8 & 7.8 & 7.7 & 7.5 & 7.7 & 7.6 \\
\hline $\mathrm{CaO}$ & 4.0 & 3.9 & 3.8 & 3.7 & 3.6 & 3.4 & 3.1 & 3.0 & 3.0 & 3.0 \\
\hline $\mathrm{Na}_{2} \mathrm{O}$ & 4.0 & 3.9 & 3.9 & 3.9 & 3.8 & 3.7 & 3.7 & 3.6 & 3.6 & 3.6 \\
\hline $\mathrm{K}_{2} \mathrm{O}$ & 2.2 & 2.2 & 2.2 & 2.3 & 2.3 & 2.3 & 2.4 & 2.5 & 2.5 & 2.5 \\
\hline \multicolumn{11}{|l|}{ Std. Dev. } \\
\hline $\mathrm{SiO}_{2}$ & 9.5 & 9.5 & 9.8 & 10.0 & 10.3 & 10.5 & 11.1 & 11.3 & 11.3 & 11.4 \\
\hline $\mathrm{Al}_{2} \mathrm{O}_{3}$ & 8.3 & 8.4 & 8.5 & 8.4 & 8.6 & 8.6 & 9.2 & 9.3 & 9.1 & 9.1 \\
\hline $\mathrm{MgO}$ & 3.0 & 2.9 & 2.8 & 2.8 & 2.8 & 2.7 & 2.7 & 2.7 & 2.8 & 2.6 \\
\hline $\mathrm{FeO}$ & 5.7 & 5.6 & 5.6 & 5.6 & 5.6 & 5.7 & 5.6 & 5.7 & 5.8 & 5.9 \\
\hline $\mathrm{CaO}$ & 2.8 & 2.7 & 2.6 & 2.4 & 2.4 & 2.3 & 2.0 & 2.0 & 2.0 & 2.0 \\
\hline $\mathrm{Na}_{2} \mathrm{O}$ & 2.2 & 2.2 & 2.2 & 2.2 & 2.2 & 2.2 & 2.3 & 2.3 & 2.3 & 2.3 \\
\hline $\mathrm{K}_{2} \mathrm{O}$ & 1.1 & 1.1 & 1.1 & 1.1 & 1.1 & 1.1 & 1.1 & 1.2 & 1.2 & 1.2 \\
\hline$N$ & 377 & 379 & 369 & 372 & 358 & 361 & 345 & 346 & 347 & 330 \\
\hline \multicolumn{11}{|c|}{$V_{p}=6.6 \mathrm{~km} / \mathrm{s}$} \\
\hline Mean & & & & & & & & & & \\
\hline $\mathrm{SiO}_{2}$ & 58.8 & 58.9 & 59.2 & 59.4 & 59.4 & 59.2 & 59.2 & 59.0 & 59.1 & 59.5 \\
\hline $\mathrm{Al}_{2} \mathrm{O}_{3}$ & 17.3 & 17.1 & 16.8 & 16.8 & 16.9 & 17.2 & 17.3 & 17.5 & 17.5 & 17.4 \\
\hline $\mathrm{MgO}$ & 5.5 & 5.5 & 5.5 & 5.5 & 5.3 & 5.1 & 5.1 & 5.0 & 4.9 & 4.7 \\
\hline $\mathrm{FeO}$ & 7.9 & 8.0 & 8.1 & 8.1 & 8.2 & 8.0 & 8.1 & 8.2 & 8.2 & 8.4 \\
\hline $\mathrm{CaO}$ & 4.8 & 4.6 & 4.5 & 4.5 & 4.4 & 4.4 & 4.1 & 4.0 & 3.9 & 3.8 \\
\hline $\mathrm{Na}_{2} \mathrm{O}$ & 3.9 & 3.9 & 3.9 & 3.9 & 3.9 & 4.0 & 4.1 & 4.2 & 4.2 & 4.2 \\
\hline $\mathrm{K}_{2} \mathrm{O}$ & 1.9 & 1.9 & 1.9 & 2.0 & 2.0 & 2.0 & 2.0 & 2.0 & 2.1 & 2.1 \\
\hline \multicolumn{11}{|l|}{ Std. Dev. } \\
\hline $\mathrm{SiO}_{2}$ & 9.7 & 10.0 & 10.1 & 10.2 & 10.5 & 10.3 & 10.4 & 10.5 & 10.6 & 10.9 \\
\hline $\mathrm{Al}_{2} \mathrm{O}_{3}$ & 8.3 & 8.6 & 8.6 & 8.5 & 8.7 & 8.6 & 8.6 & 8.7 & 8.6 & 8.9 \\
\hline $\mathrm{MgO}$ & 3.4 & 3.4 & 3.4 & 3.4 & 3.3 & 3.3 & 3.3 & 3.3 & 3.2 & 3.1 \\
\hline $\mathrm{FeO}$ & 5.6 & 5.6 & 5.7 & 5.6 & 5.7 & 5.8 & 5.8 & 5.8 & 5.9 & 5.9 \\
\hline $\mathrm{CaO}$ & 3.0 & 3.0 & 2.9 & 2.9 & 2.9 & 2.9 & 2.7 & 2.7 & 2.6 & 2.6 \\
\hline $\mathrm{Na}_{2} \mathrm{O}$ & 2.2 & 2.2 & 2.3 & 2.2 & 2.3 & 2.2 & 2.2 & 2.2 & 2.2 & 2.3 \\
\hline $\mathrm{K}_{2} \mathrm{O}$ & 1.1 & 1.1 & 1.1 & 1.1 & 1.1 & 1.1 & 1.1 & 1.1 & 1.1 & 1.1 \\
\hline$N$ & 516 & 514 & 493 & 487 & 478 & 477 & 456 & 447 & 438 & 429 \\
\hline \multicolumn{11}{|c|}{$V_{p}=6.7 \mathrm{~km} / \mathrm{s}$} \\
\hline \multicolumn{11}{|l|}{ Mean } \\
\hline $\mathrm{SiO}_{2}$ & 56.6 & 56.5 & 56.5 & 56.8 & 56.9 & 56.9 & 56.8 & 56.9 & 56.9 & 57.7 \\
\hline $\mathrm{Al}_{2} \mathrm{O}_{3}$ & 17.7 & 17.8 & 17.9 & 17.7 & 17.8 & 17.9 & 18.1 & 18.2 & 18.3 & 17.8 \\
\hline $\mathrm{MgO}$ & 6.7 & 6.6 & 6.5 & 6.5 & 6.2 & 6.0 & 5.8 & 5.7 & 5.7 & 5.7 \\
\hline $\mathrm{FeO}$ & 8.3 & 8.3 & 8.4 & 8.4 & 8.4 & 8.5 & 8.5 & 8.5 & 8.6 & 8.4 \\
\hline $\mathrm{CaO}$ & 5.2 & 5.3 & 5.2 & 5.1 & 5.1 & 5.1 & 5.0 & 4.8 & 4.6 & 4.6 \\
\hline $\mathrm{Na}_{2} \mathrm{O}$ & 3.9 & 3.9 & 3.9 & 3.9 & 3.9 & 4.0 & 4.1 & 4.1 & 4.2 & 4.1 \\
\hline $\mathrm{K}_{2} \mathrm{O}$ & 1.6 & 1.6 & 1.6 & 1.6 & 1.7 & 1.7 & 1.7 & 1.7 & 1.7 & 1.8 \\
\hline
\end{tabular}


Table A.1. (continued)

\begin{tabular}{|c|c|c|c|c|c|c|c|c|c|c|}
\hline Depth (km) & 5 & 10 & 15 & 20 & 25 & 30 & 35 & 40 & 45 & 50 \\
\hline $\mathrm{T}\left({ }^{\circ} \mathrm{C}\right)$ & 91 & 155 & 211 & 263 & 311 & 359 & 405 & 451 & 496 & 541 \\
\hline P (kbar) & 1.6 & 3.2 & 4.9 & 6.5 & 8.1 & 9.7 & 11.3 & 12.9 & 14.6 & 16.2 \\
\hline \multicolumn{11}{|l|}{ Std. Dev. } \\
\hline $\mathrm{SiO}_{2}$ & 10.0 & 10.0 & 10.1 & 10.3 & 10.2 & 10.3 & 10.2 & 10.3 & 10.3 & 10.4 \\
\hline $\mathrm{Al}_{2} \mathrm{O}_{3}$ & 8.5 & 8.4 & 8.4 & 8.6 & 8.5 & 8.5 & 8.4 & 8.2 & 8.3 & 8.4 \\
\hline $\mathrm{MgO}$ & 3.6 & 3.6 & 3.6 & 3.6 & 3.5 & 3.4 & 3.4 & 3.4 & 3.4 & 3.4 \\
\hline $\mathrm{FeO}$ & 5.4 & 5.4 & 5.4 & 5.5 & 5.5 & 5.5 & 5.6 & 5.7 & 5.7 & 5.6 \\
\hline $\mathrm{CaO}$ & 3.3 & 3.3 & 3.3 & 3.2 & 3.2 & 3.2 & 3.1 & 3.0 & 2.9 & 2.9 \\
\hline $\mathrm{Na}_{2} \mathrm{O}$ & 2.3 & 2.3 & 2.3 & 2.3 & 2.3 & 2.3 & 2.3 & 2.2 & 2.2 & 2.2 \\
\hline $\mathrm{K}_{2} \mathrm{O}$ & 1.0 & 1.0 & 1.0 & 1.0 & 1.0 & 1.0 & 1.0 & 1.0 & 1.0 & 1.1 \\
\hline$N$ & 591 & 596 & 594 & 583 & 586 & 582 & 583 & 578 & 559 & 563 \\
\hline \multicolumn{11}{|c|}{$V_{p}=6.8 \mathrm{~km} / \mathrm{s}$} \\
\hline \multicolumn{11}{|l|}{ Mean } \\
\hline $\mathrm{SiO}_{2}$ & 54.9 & 55.1 & 55.1 & 55.0 & 55.2 & 55.5 & 55.7 & 55.9 & 55.9 & 56.1 \\
\hline $\mathrm{Al}_{2} \mathrm{O}_{3}$ & 18.2 & 18.0 & 18.2 & 18.4 & 18.3 & 18.0 & 17.9 & 17.8 & 17.9 & 18.0 \\
\hline $\mathrm{MgO}$ & 8.0 & 8.0 & 7.7 & 7.5 & 7.6 & 7.6 & 7.5 & 7.3 & 7.2 & 7.0 \\
\hline $\mathrm{FeO}$ & 7.9 & 7.9 & 7.8 & 8.0 & 7.9 & 8.0 & 8.1 & 8.1 & 8.1 & 8.1 \\
\hline $\mathrm{CaO}$ & 5.8 & 5.8 & 5.8 & 5.7 & 5.6 & 5.5 & 5.6 & 5.5 & 5.4 & 5.4 \\
\hline $\mathrm{Na}_{2} \mathrm{O}$ & 3.8 & 3.8 & 3.8 & 3.9 & 3.9 & 3.8 & 3.8 & 3.8 & 3.9 & 3.9 \\
\hline $\mathrm{K}_{2} \mathrm{O}$ & 1.5 & 1.5 & 1.5 & 1.5 & 1.5 & 1.5 & 1.5 & 1.5 & 1.5 & 1.6 \\
\hline \multicolumn{11}{|l|}{ Std. Dev. } \\
\hline $\mathrm{SiO}_{2}$ & 9.8 & 9.7 & 9.8 & 9.9 & 9.9 & 10.0 & 10.1 & 10.3 & 10.2 & 10.2 \\
\hline $\mathrm{Al}_{2} \mathrm{O}_{3}$ & 8.3 & 8.3 & 8.3 & 8.4 & 8.3 & 8.4 & 8.5 & 8.5 & 8.5 & 8.4 \\
\hline $\mathrm{MgO}$ & 4.2 & 4.1 & 4.0 & 3.9 & 3.9 & 3.9 & 3.8 & 3.7 & 3.7 & 3.6 \\
\hline $\mathrm{FeO}$ & 5.3 & 5.2 & 5.3 & 5.3 & 5.3 & 5.3 & 5.3 & 5.3 & 5.3 & 5.2 \\
\hline $\mathrm{CaO}$ & 3.8 & 3.8 & 3.8 & 3.6 & 3.6 & 3.5 & 3.5 & 3.4 & 3.4 & 3.4 \\
\hline $\mathrm{Na}_{2} \mathrm{O}$ & 2.3 & 2.3 & 2.3 & 2.3 & 2.3 & 2.3 & 2.3 & 2.4 & 2.3 & 2.3 \\
\hline $\mathrm{K}_{2} \mathrm{O}$ & 0.9 & 0.9 & 0.9 & 0.9 & 0.9 & 0.9 & 1.0 & 0.9 & 0.9 & 1.0 \\
\hline$N$ & 674 & 684 & 685 & 674 & 683 & 683 & 683 & 668 & 661 & 650 \\
\hline \multicolumn{11}{|c|}{$V_{p}=6.9 \mathrm{~km} / \mathrm{s}$} \\
\hline Mean & & & & & & & & & & \\
\hline $\mathrm{SiO}_{2}$ & 54.2 & 54.3 & 54.6 & 54.5 & 54.6 & 54.8 & 55.1 & 55.3 & 55.6 & 55.4 \\
\hline $\mathrm{Al}_{2} \mathrm{O}_{3}$ & 17.8 & 17.7 & 17.6 & 17.8 & 17.7 & 17.6 & 17.4 & 17.4 & 17.3 & 17.5 \\
\hline $\mathrm{MgO}$ & 9.3 & 9.3 & 9.4 & 9.2 & 9.2 & 9.2 & 9.1 & 8.8 & 8.7 & 8.7 \\
\hline $\mathrm{FeO}$ & 7.1 & 7.1 & 7.0 & 7.1 & 7.2 & 7.1 & 7.1 & 7.2 & 7.1 & 7.2 \\
\hline $\mathrm{CaO}$ & 6.7 & 6.5 & 6.5 & 6.5 & 6.2 & 6.3 & 6.3 & 6.3 & 6.3 & 6.1 \\
\hline $\mathrm{Na}_{2} \mathrm{O}$ & 3.6 & 3.6 & 3.5 & 3.6 & 3.6 & 3.6 & 3.5 & 3.5 & 3.5 & 3.6 \\
\hline $\mathrm{K}_{2} \mathrm{O}$ & 1.4 & 1.4 & 1.5 & 1.4 & 1.5 & 1.5 & 1.5 & 1.5 & 1.5 & 1.5 \\
\hline \multicolumn{11}{|l|}{ Std. Dev. } \\
\hline $\mathrm{SiO}_{2}$ & 9.3 & 9.3 & 9.2 & 9.2 & 9.3 & 9.3 & 9.3 & 9.4 & 9.4 & 9.6 \\
\hline $\mathrm{Al}_{2} \mathrm{O}_{3}$ & 8.1 & 8.2 & 8.1 & 8.1 & 8.2 & 8.2 & 8.1 & 8.3 & 8.2 & 8.3 \\
\hline $\mathrm{MgO}$ & 4.9 & 4.9 & 4.8 & 4.8 & 4.8 & 4.8 & 4.7 & 4.6 & 4.6 & 4.5 \\
\hline $\mathrm{FeO}$ & 4.8 & 4.8 & 4.8 & 4.8 & 4.8 & 4.8 & 4.7 & 4.7 & 4.7 & 4.8 \\
\hline $\mathrm{CaO}$ & 4.3 & 4.2 & 4.2 & 4.2 & 4.1 & 4.0 & 3.9 & 4.0 & 3.8 & 3.7 \\
\hline $\mathrm{Na}_{2} \mathrm{O}$ & 2.2 & 2.2 & 2.2 & 2.2 & 2.2 & 2.2 & 2.2 & 2.2 & 2.2 & 2.2 \\
\hline $\mathrm{K}_{2} \mathrm{O}$ & 0.9 & 0.9 & 0.9 & 0.9 & 0.9 & 0.9 & 0.9 & 0.9 & 0.9 & 0.9 \\
\hline$N$ & 688 & 681 & 697 & 709 & 703 & 709 & 722 & 709 & 697 & 694 \\
\hline \multicolumn{11}{|c|}{$V_{p}=7.0 \mathrm{~km} / \mathrm{s}$} \\
\hline \multicolumn{11}{|l|}{ Mean } \\
\hline $\mathrm{SiO}_{2}$ & 52.9 & 52.8 & 53.1 & 53.4 & 53.5 & 53.5 & 53.6 & 53.8 & 54.1 & 54.3 \\
\hline $\mathrm{Al}_{2} \mathrm{O}_{3}$ & 17.6 & 17.6 & 17.4 & 17.3 & 17.3 & 17.3 & 17.4 & 17.4 & 17.2 & 17.3 \\
\hline $\mathrm{MgO}$ & 10.8 & 10.8 & 10.8 & 10.7 & 10.6 & 10.5 & 10.4 & 10.1 & 10.0 & 10.0 \\
\hline
\end{tabular}


Table A.1. (continued)

\begin{tabular}{|c|c|c|c|c|c|c|c|c|c|c|}
\hline Depth (km) & 5 & 10 & 15 & 20 & 25 & 30 & 35 & 40 & 45 & 50 \\
\hline $\mathrm{T}\left({ }^{\circ} \mathrm{C}\right)$ & 91 & 155 & 211 & 263 & 311 & 359 & 405 & 451 & 496 & 541 \\
\hline P (kbar) & 1.6 & 3.2 & 4.9 & 6.5 & 8.1 & 9.7 & 11.3 & 12.9 & 14.6 & 16.2 \\
\hline $\mathrm{FeO}$ & 7.0 & 7.1 & 7.1 & 7.0 & 7.0 & 7.0 & 6.9 & 7.0 & 7.0 & 7.0 \\
\hline $\mathrm{CaO}$ & 7.2 & 7.1 & 7.1 & 7.1 & 7.1 & 7.0 & 7.0 & 6.9 & 6.9 & 6.7 \\
\hline $\mathrm{Na}_{2} \mathrm{O}$ & 3.3 & 3.4 & 3.3 & 3.3 & 3.3 & 3.3 & 3.4 & 3.4 & 3.3 & 3.4 \\
\hline $\mathrm{K}_{2} \mathrm{O}$ & 1.2 & 1.2 & 1.2 & 1.3 & 1.3 & 1.3 & 1.3 & 1.4 & 1.4 & 1.4 \\
\hline \multicolumn{11}{|l|}{ Std. Dev. } \\
\hline $\mathrm{SiO}_{2}$ & 8.9 & 8.9 & 8.9 & 8.9 & 8.9 & 8.9 & 9.0 & 9.0 & 9.1 & 9.2 \\
\hline $\mathrm{Al}_{2} \mathrm{O}_{3}$ & 7.8 & 7.9 & 7.9 & 7.8 & 7.8 & 7.8 & 7.8 & 7.8 & 8.0 & 8.0 \\
\hline $\mathrm{MgO}$ & 5.4 & 5.5 & 5.4 & 5.5 & 5.5 & 5.5 & 5.5 & 5.4 & 5.3 & 5.3 \\
\hline $\mathrm{FeO}$ & 4.8 & 4.7 & 4.7 & 4.7 & 4.7 & 4.7 & 4.6 & 4.6 & 4.6 & 4.6 \\
\hline $\mathrm{CaO}$ & 4.7 & 4.7 & 4.6 & 4.6 & 4.6 & 4.6 & 4.5 & 4.4 & 4.3 & 4.1 \\
\hline $\mathrm{Na}_{2} \mathrm{O}$ & 2.1 & 2.1 & 2.1 & 2.0 & 2.0 & 2.0 & 2.0 & 2.0 & 2.1 & 2.1 \\
\hline $\mathrm{K}_{2} \mathrm{O}$ & 0.8 & 0.8 & 0.8 & 0.9 & 0.9 & 0.9 & 0.9 & 0.9 & 0.9 & 0.9 \\
\hline$N$ & 613 & 607 & 632 & 653 & 649 & 663 & 664 & 663 & 674 & 688 \\
\hline \multicolumn{11}{|c|}{$V_{p}=7.1 \mathrm{~km} / \mathrm{s}$} \\
\hline Mean & & & & & & & & & & \\
\hline $\mathrm{SiO}_{2}$ & 51.3 & 51.3 & 51.3 & 51.5 & 51.6 & 51.7 & 51.7 & 51.9 & 51.9 & 52.2 \\
\hline $\mathrm{Al}_{2} \mathrm{O}_{3}$ & 17.6 & 17.6 & 17.8 & 17.6 & 17.7 & 17.6 & 17.7 & 17.8 & 17.9 & 17.8 \\
\hline $\mathrm{MgO}$ & 12.3 & 12.2 & 12.1 & 12.0 & 12.0 & 12.0 & 11.8 & 11.6 & 11.3 & 11.1 \\
\hline $\mathrm{FeO}$ & 7.2 & 7.1 & 7.1 & 7.1 & 7.0 & 7.0 & 7.2 & 7.1 & 7.2 & 7.2 \\
\hline $\mathrm{CaO}$ & 7.2 & 7.3 & 7.4 & 7.4 & 7.4 & 7.2 & 7.1 & 7.2 & 7.2 & 7.3 \\
\hline $\mathrm{Na}_{2} \mathrm{O}$ & 3.3 & 3.3 & 3.3 & 3.3 & 3.3 & 3.3 & 3.3 & 3.3 & 3.4 & 3.3 \\
\hline $\mathrm{K}_{2} \mathrm{O}$ & 1.1 & 1.1 & 1.1 & 1.1 & 1.1 & 1.1 & 1.1 & 1.1 & 1.1 & 1.1 \\
\hline \multicolumn{11}{|l|}{ Std. Dev. } \\
\hline $\mathrm{SiO}_{2}$ & 8.7 & 8.7 & 8.7 & 8.8 & 8.8 & 8.8 & 9.1 & 9.1 & 9.2 & 9.2 \\
\hline $\mathrm{Al}_{2} \mathrm{O}_{3}$ & 7.7 & 7.7 & 7.7 & 7.7 & 7.7 & 7.7 & 7.8 & 7.8 & 7.9 & 7.9 \\
\hline $\mathrm{MgO}$ & 5.9 & 5.9 & 5.9 & 5.9 & 5.8 & 5.8 & 5.8 & 5.7 & 5.6 & 5.6 \\
\hline $\mathrm{FeO}$ & 5.0 & 5.0 & 5.0 & 5.0 & 5.0 & 5.0 & 5.0 & 5.0 & 5.0 & 5.0 \\
\hline $\mathrm{CaO}$ & 5.0 & 5.1 & 5.1 & 5.1 & 5.0 & 4.9 & 4.9 & 4.8 & 4.8 & 4.8 \\
\hline $\mathrm{Na}_{2} \mathrm{O}$ & 2.1 & 2.1 & 2.1 & 2.1 & 2.0 & 2.0 & 2.1 & 2.0 & 2.1 & 2.1 \\
\hline $\mathrm{K}_{2} \mathrm{O}$ & 0.8 & 0.8 & 0.8 & 0.8 & 0.8 & 0.8 & 0.8 & 0.8 & 0.8 & 0.8 \\
\hline$N$ & 550 & 567 & 566 & 575 & 588 & 598 & 588 & 612 & 636 & 652 \\
\hline \multicolumn{11}{|c|}{$V_{p}=7.2 \mathrm{~km} / \mathrm{s}$} \\
\hline Mean & & & & & & & & & & \\
\hline $\mathrm{SiO}_{2}$ & 50.4 & 50.5 & 50.2 & 50.3 & 50.5 & 50.6 & 50.8 & 51.1 & 50.9 & 51.1 \\
\hline $\mathrm{Al}_{2} \mathrm{O}_{3}$ & 17.6 & 17.6 & 17.9 & 17.9 & 17.8 & 17.7 & 17.7 & 17.6 & 17.6 & 17.4 \\
\hline $\mathrm{MgO}$ & 12.8 & 12.7 & 12.7 & 12.6 & 12.6 & 12.7 & 12.6 & 12.6 & 12.5 & 12.6 \\
\hline $\mathrm{FeO}$ & 7.2 & 7.1 & 7.1 & 7.1 & 7.0 & 7.0 & 7.0 & 6.9 & 7.0 & 7.0 \\
\hline $\mathrm{CaO}$ & 7.7 & 7.8 & 7.8 & 7.8 & 7.8 & 7.8 & 7.8 & 7.7 & 7.7 & 7.7 \\
\hline $\mathrm{Na}_{2} \mathrm{O}$ & 3.2 & 3.2 & 3.3 & 3.3 & 3.2 & 3.2 & 3.2 & 3.2 & 3.2 & 3.2 \\
\hline $\mathrm{K}_{2} \mathrm{O}$ & 1.0 & 1.0 & 1.0 & 1.0 & 1.0 & 1.0 & 1.0 & 1.0 & 1.0 & 1.0 \\
\hline \multicolumn{11}{|l|}{ Std. Dev. } \\
\hline $\mathrm{SiO}_{2}$ & 8.5 & 8.5 & 8.6 & 8.6 & 8.6 & 8.6 & 8.5 & 8.5 & 8.4 & 8.5 \\
\hline $\mathrm{Al}_{2} \mathrm{O}_{3}$ & 7.9 & 7.9 & 7.9 & 7.9 & 7.7 & 7.8 & 7.7 & 7.6 & 7.5 & 7.6 \\
\hline $\mathrm{MgO}$ & 6.4 & 6.3 & 6.3 & 6.2 & 6.1 & 6.1 & 6.1 & 6.1 & 6.1 & 6.1 \\
\hline $\mathrm{FeO}$ & 4.8 & 4.9 & 4.9 & 4.9 & 4.8 & 4.9 & 4.9 & 4.9 & 5.0 & 5.0 \\
\hline $\mathrm{CaO}$ & 5.1 & 5.2 & 5.2 & 5.2 & 5.1 & 5.1 & 5.1 & 5.1 & 5.1 & 5.0 \\
\hline $\mathrm{Na}_{2} \mathrm{O}$ & 2.0 & 2.0 & 2.0 & 2.0 & 2.0 & 2.0 & 2.0 & 2.0 & 1.9 & 2.0 \\
\hline $\mathrm{K}_{2} \mathrm{O}$ & 0.8 & 0.8 & 0.8 & 0.7 & 0.7 & 0.7 & 0.7 & 0.7 & 0.7 & 0.7 \\
\hline$N$ & 471 & 481 & 481 & 488 & 506 & 499 & 524 & 555 & 568 & 583 \\
\hline
\end{tabular}


Table A.1. (continued)

\begin{tabular}{|c|c|c|c|c|c|c|c|c|c|c|}
\hline Depth (km) & 5 & 10 & 15 & 20 & 25 & 30 & 35 & 40 & 45 & 50 \\
\hline $\mathrm{T}\left({ }^{\circ} \mathrm{C}\right)$ & 91 & 155 & 211 & 263 & 311 & 359 & 405 & 451 & 496 & 541 \\
\hline P (kbar) & 1.6 & 3.2 & 4.9 & 6.5 & 8.1 & 9.7 & 11.3 & 12.9 & 14.6 & 16.2 \\
\hline \multicolumn{11}{|c|}{$V_{p}=7.3 \mathrm{~km} / \mathrm{s}$} \\
\hline Mean & & & & & & & & & & \\
\hline $\mathrm{SiO}_{2}$ & 48.5 & 48.5 & 48.5 & 48.8 & 49.0 & 49.0 & 49.5 & 49.6 & 49.7 & 49.5 \\
\hline $\mathrm{Al}_{2} \mathrm{O}_{3}$ & 18.9 & 19.1 & 18.9 & 18.7 & 18.6 & 18.6 & 18.3 & 18.1 & 18.0 & 18.2 \\
\hline $\mathrm{MgO}$ & 12.7 & 12.6 & 12.7 & 12.7 & 12.6 & 12.5 & 12.7 & 12.8 & 13.0 & 12.9 \\
\hline $\mathrm{FeO}$ & 6.7 & 6.6 & 6.6 & 6.6 & 6.7 & 6.6 & 6.4 & 6.5 & 6.5 & 6.5 \\
\hline $\mathrm{CaO}$ & 9.0 & 9.1 & 9.1 & 9.1 & 9.0 & 9.1 & 9.1 & 9.0 & 8.9 & 8.7 \\
\hline $\mathrm{Na}_{2} \mathrm{O}$ & 3.3 & 3.3 & 3.3 & 3.2 & 3.2 & 3.2 & 3.1 & 3.1 & 3.1 & 3.2 \\
\hline $\mathrm{K}_{2} \mathrm{O}$ & 0.9 & 0.9 & 0.9 & 0.9 & 0.9 & 0.9 & 0.9 & 0.9 & 0.9 & 1.0 \\
\hline \multicolumn{11}{|l|}{ Std. Dev. } \\
\hline $\mathrm{SiO}_{2}$ & 7.8 & 7.8 & 7.8 & 8.0 & 8.0 & 8.0 & 8.1 & 8.1 & 8.0 & 8.1 \\
\hline $\mathrm{Al}_{2} \mathrm{O}_{3}$ & 7.7 & 7.6 & 7.7 & 7.7 & 7.8 & 7.7 & 7.7 & 7.7 & 7.6 & 7.7 \\
\hline $\mathrm{MgO}$ & 6.9 & 6.9 & 6.8 & 6.7 & 6.8 & 6.7 & 6.7 & 6.7 & 6.7 & 6.8 \\
\hline $\mathrm{FeO}$ & 4.3 & 4.3 & 4.3 & 4.3 & 4.4 & 4.3 & 4.4 & 4.4 & 4.5 & 4.4 \\
\hline $\mathrm{CaO}$ & 5.6 & 5.6 & 5.5 & 5.5 & 5.4 & 5.5 & 5.4 & 5.5 & 5.5 & 5.5 \\
\hline $\mathrm{Na}_{2} \mathrm{O}$ & 1.9 & 1.9 & 1.8 & 1.9 & 1.9 & 1.9 & 1.9 & 1.9 & 1.8 & 1.8 \\
\hline $\mathrm{K}_{2} \mathrm{O}$ & 0.7 & 0.7 & 0.7 & 0.7 & 0.7 & 0.7 & 0.7 & 0.7 & 0.7 & 0.7 \\
\hline$N$ & 413 & 406 & 413 & 421 & 427 & 434 & 462 & 471 & 484 & 471 \\
\hline \multicolumn{11}{|c|}{$V_{p}=7.4 \mathrm{~km} / \mathrm{s}$} \\
\hline Mean & & & & & & & & & & \\
\hline $\mathrm{SiO}_{2}$ & 47.4 & 47.5 & 47.8 & 47.9 & 47.8 & 47.8 & 47.7 & 47.7 & 47.9 & 48.0 \\
\hline $\mathrm{Al}_{2} \mathrm{O}_{3}$ & 19.0 & 19.0 & 18.8 & 18.7 & 18.8 & 19.0 & 19.0 & 19.1 & 19.1 & 19.1 \\
\hline $\mathrm{MgO}$ & 13.9 & 13.9 & 13.9 & 13.9 & 13.9 & 13.5 & 13.5 & 13.3 & 13.2 & 13.0 \\
\hline $\mathrm{FeO}$ & 6.1 & 6.0 & 6.0 & 6.0 & 6.0 & 6.1 & 6.1 & 6.0 & 6.1 & 6.1 \\
\hline $\mathrm{CaO}$ & 9.6 & 9.6 & 9.6 & 9.6 & 9.6 & 9.7 & 9.7 & 9.8 & 9.6 & 9.9 \\
\hline $\mathrm{Na}_{2} \mathrm{O}$ & 3.2 & 3.2 & 3.1 & 3.1 & 3.1 & 3.1 & 3.1 & 3.2 & 3.2 & 3.1 \\
\hline $\mathrm{K}_{2} \mathrm{O}$ & 0.8 & 0.8 & 0.8 & 0.8 & 0.8 & 0.8 & 0.8 & 0.9 & 0.9 & 0.9 \\
\hline \multicolumn{11}{|l|}{ Std. Dev. } \\
\hline $\mathrm{SiO}_{2}$ & 7.3 & 7.3 & 7.2 & 7.2 & 7.3 & 7.3 & 7.3 & 7.3 & 7.5 & 7.4 \\
\hline $\mathrm{Al}_{2} \mathrm{O}_{3}$ & 7.4 & 7.4 & 7.2 & 7.3 & 7.3 & 7.3 & 7.3 & 7.2 & 7.3 & 7.2 \\
\hline $\mathrm{MgO}$ & 7.5 & 7.5 & 7.5 & 7.5 & 7.5 & 7.5 & 7.4 & 7.4 & 7.4 & 7.4 \\
\hline $\mathrm{FeO}$ & 4.2 & 4.1 & 4.1 & 4.1 & 4.1 & 4.1 & 4.1 & 4.1 & 4.1 & 4.1 \\
\hline $\mathrm{CaO}$ & 5.9 & 5.9 & 5.9 & 5.9 & 5.9 & 5.9 & 5.9 & 5.9 & 5.8 & 5.9 \\
\hline $\mathrm{Na}_{2} \mathrm{O}$ & 1.8 & 1.8 & 1.8 & 1.8 & 1.8 & 1.8 & 1.8 & 1.8 & 1.8 & 1.8 \\
\hline $\mathrm{K}_{2} \mathrm{O}$ & 0.7 & 0.7 & 0.7 & 0.7 & 0.7 & 0.7 & 0.7 & 0.7 & 0.7 & 0.7 \\
\hline$N$ & 344 & 345 & 354 & 361 & 361 & 365 & 364 & 370 & 367 & 378 \\
\hline \multicolumn{11}{|c|}{$V_{p}=7.5 \mathrm{~km} / \mathrm{s}$} \\
\hline Mean & & & & & & & & & & \\
\hline $\mathrm{SiO}_{2}$ & 47.6 & 47.4 & 47.4 & 47.3 & 47.4 & 47.4 & 47.4 & 47.6 & 47.6 & 47.8 \\
\hline $\mathrm{Al}_{2} \mathrm{O}_{3}$ & 18.2 & 18.3 & 18.3 & 18.4 & 18.4 & 18.4 & 18.4 & 18.4 & 18.4 & 18.1 \\
\hline $\mathrm{MgO}$ & 15.0 & 15.0 & 15.0 & 15.0 & 14.7 & 14.7 & 14.7 & 14.6 & 14.5 & 14.5 \\
\hline $\mathrm{FeO}$ & 5.8 & 5.8 & 5.8 & 5.8 & 5.8 & 5.8 & 5.7 & 5.7 & 5.7 & 5.8 \\
\hline $\mathrm{CaO}$ & 9.7 & 9.8 & 9.8 & 9.7 & 10.0 & 10.0 & 10.0 & 9.9 & 9.9 & 10.1 \\
\hline $\mathrm{Na}_{2} \mathrm{O}$ & 2.9 & 2.9 & 2.9 & 3.0 & 2.9 & 2.9 & 2.9 & 2.9 & 3.0 & 2.8 \\
\hline $\mathrm{K}_{2} \mathrm{O}$ & 0.8 & 0.8 & 0.8 & 0.8 & 0.8 & 0.8 & 0.8 & 0.8 & 0.8 & 0.8 \\
\hline \multicolumn{11}{|l|}{ Std. Dev. } \\
\hline $\mathrm{SiO}_{2}$ & 7.2 & 7.2 & 7.2 & 7.2 & 7.1 & 7.1 & 7.0 & 7.0 & 7.1 & 7.1 \\
\hline $\mathrm{Al}_{2} \mathrm{O}_{3}$ & 6.6 & 6.5 & 6.6 & 6.6 & 6.5 & 6.4 & 6.4 & 6.3 & 6.3 & 6.4 \\
\hline $\mathrm{MgO}$ & 8.0 & 7.9 & 7.9 & 8.0 & 8.0 & 8.0 & 8.0 & 8.0 & 8.0 & 7.8 \\
\hline $\mathrm{FeO}$ & 4.0 & 3.9 & 3.9 & 3.9 & 3.8 & 3.9 & 3.9 & 3.9 & 3.9 & 3.9 \\
\hline $\mathrm{CaO}$ & 6.3 & 6.2 & 6.2 & 6.2 & 6.3 & 6.3 & 6.3 & 6.2 & 6.2 & 6.1 \\
\hline
\end{tabular}


Table A.1. (continued)

\begin{tabular}{|c|c|c|c|c|c|c|c|c|c|c|}
\hline Depth (km) & 5 & 10 & 15 & 20 & 25 & 30 & 35 & 40 & 45 & 50 \\
\hline $\mathrm{T}\left({ }^{\circ} \mathrm{C}\right)$ & 91 & 155 & 211 & 263 & 311 & 359 & 405 & 451 & 496 & 541 \\
\hline P (kbar) & 1.6 & 3.2 & 4.9 & 6.5 & 8.1 & 9.7 & 11.3 & 12.9 & 14.6 & 16.2 \\
\hline $\mathrm{Na}_{2} \mathrm{O}$ & 1.8 & 1.8 & 1.8 & 1.8 & 1.8 & 1.8 & 1.8 & 1.7 & 1.7 & 1.8 \\
\hline $\mathrm{K}_{2} \mathrm{O}$ & 0.6 & 0.6 & 0.7 & 0.7 & 0.7 & 0.7 & 0.7 & 0.7 & 0.7 & 0.7 \\
\hline$N$ & 246 & 258 & 256 & 263 & 274 & 273 & 275 & 282 & 289 & 312 \\
\hline \multicolumn{11}{|c|}{$V_{p}=7.6 \mathrm{~km} / \mathrm{s}$} \\
\hline \multicolumn{11}{|l|}{ Mean } \\
\hline $\mathrm{SiO}_{2}$ & 44.9 & 44.9 & 44.9 & 44.8 & 44.8 & 45.0 & 45.1 & 45.0 & 44.4 & 44.5 \\
\hline $\mathrm{Al}_{2} \mathrm{O}_{3}$ & 20.5 & 20.4 & 20.3 & 20.3 & 20.4 & 20.1 & 20.1 & 20.1 & 20.5 & 20.5 \\
\hline $\mathrm{MgO}$ & 14.1 & 14.2 & 14.3 & 14.3 & 14.3 & 14.6 & 14.6 & 14.6 & 14.5 & 14.4 \\
\hline $\mathrm{FeO}$ & 4.9 & 4.9 & 5.1 & 5.2 & 5.1 & 5.1 & 5.0 & 5.0 & 5.2 & 5.2 \\
\hline $\mathrm{CaO}$ & 11.4 & 11.4 & 11.2 & 11.3 & 11.3 & 11.2 & 11.2 & 11.2 & 11.2 & 11.2 \\
\hline $\mathrm{Na}_{2} \mathrm{O}$ & 3.3 & 3.3 & 3.3 & 3.3 & 3.3 & 3.2 & 3.2 & 3.2 & 3.3 & 3.3 \\
\hline $\mathrm{K}_{2} \mathrm{O}$ & 0.9 & 0.9 & 0.9 & 0.9 & 0.9 & 0.9 & 0.9 & 0.9 & 0.8 & 0.8 \\
\hline \multicolumn{11}{|l|}{ Std. Dev. } \\
\hline $\mathrm{SiO}_{2}$ & 7.3 & 7.3 & 7.4 & 7.3 & 7.5 & 7.5 & 7.5 & 7.6 & 8.1 & 8.1 \\
\hline $\mathrm{Al}_{2} \mathrm{O}_{3}$ & 6.0 & 6.0 & 6.3 & 6.4 & 6.5 & 6.5 & 6.5 & 6.7 & 6.9 & 6.9 \\
\hline $\mathrm{MgO}$ & 7.6 & 7.7 & 7.7 & 7.7 & 7.6 & 7.6 & 7.6 & 7.6 & 7.3 & 7.3 \\
\hline $\mathrm{FeO}$ & 3.6 & 3.6 & 3.8 & 3.8 & 3.8 & 3.8 & 3.6 & 3.6 & 3.6 & 3.6 \\
\hline $\mathrm{CaO}$ & 6.0 & 6.0 & 6.0 & 6.0 & 6.0 & 5.9 & 5.8 & 5.8 & 5.7 & 5.7 \\
\hline $\mathrm{Na}_{2} \mathrm{O}$ & 1.7 & 1.7 & 1.8 & 1.7 & 1.8 & 1.8 & 1.7 & 1.8 & 1.8 & 1.8 \\
\hline $\mathrm{K}_{2} \mathrm{O}$ & 0.7 & 0.7 & 0.7 & 0.7 & 0.7 & 0.7 & 0.7 & 0.7 & 0.6 & 0.6 \\
\hline$N$ & 215 & 217 & 217 & 219 & 223 & 231 & 234 & 241 & 265 & 270 \\
\hline
\end{tabular}

${ }^{\mathrm{a}} N$ denotes number of synthetic compositions in each $V_{p}$ bin.

Table A.2. Mean and Standard Deviation of Major Element Oxides as a Function of $V_{p}$ for a Cold Continental Geotherm $\left(q_{s}=35 \mathrm{~mW} \mathrm{~m}^{-2}\right)^{\mathrm{a}}$

\begin{tabular}{|c|c|c|c|c|c|c|c|c|c|c|}
\hline Depth $(\mathrm{km})$ & 5 & 10 & 15 & 20 & 25 & 30 & 35 & 40 & 45 & 50 \\
\hline $\mathrm{T}\left({ }^{\circ} \mathrm{C}\right)$ & 62 & 101 & 136 & 168 & 198 & 227 & 256 & 284 & 312 & 340 \\
\hline P (kbar) & 1.6 & 3.2 & 4.9 & 6.5 & 8.1 & 9.7 & 11.3 & 12.9 & 14.6 & 16.2 \\
\hline \multicolumn{11}{|c|}{$V_{p}=6.2 \mathrm{~km} / \mathrm{s}$} \\
\hline Mean & & & & & & & & & & \\
\hline $\mathrm{SiO}_{2}$ & 76.3 & 76.8 & 77.4 & 77.5 & 76.3 & 77.0 & 79.8 & 80.8 & 83.3 & 81.1 \\
\hline $\mathrm{Al}_{2} \mathrm{O}_{3}$ & 7.1 & 6.9 & 6.4 & 6.0 & 7.2 & 6.9 & 8.2 & 7.4 & 5.4 & 7.4 \\
\hline $\mathrm{MgO}$ & 2.1 & 2.1 & 2.1 & 1.6 & 1.3 & 0.9 & 0.7 & 0.7 & 1.0 & 1.1 \\
\hline $\mathrm{FeO}$ & 7.3 & 7.3 & 7.3 & 7.8 & 9.3 & 9.1 & 5.0 & 5.3 & 5.5 & 4.7 \\
\hline $\mathrm{CaO}$ & 2.0 & 1.9 & 1.8 & 2.0 & 1.4 & 1.5 & 1.2 & 1.2 & 0.8 & 0.7 \\
\hline $\mathrm{Na}_{2} \mathrm{O}$ & 2.2 & 2.2 & 2.1 & 2.1 & 2.1 & 2.1 & 2.2 & 1.9 & 1.4 & 2.1 \\
\hline $\mathrm{K}_{2} \mathrm{O}$ & 2.9 & 2.9 & 2.9 & 3.0 & 2.4 & 2.4 & 2.8 & 2.7 & 2.6 & 2.9 \\
\hline \multicolumn{11}{|l|}{ Std. Dev. } \\
\hline $\mathrm{SiO}_{2}$ & 6.5 & 6.2 & 5.8 & 6.1 & 6.7 & 7.7 & 7.0 & 6.5 & 6.3 & 7.1 \\
\hline $\mathrm{Al}_{2} \mathrm{O}_{3}$ & 5.3 & 5.1 & 4.8 & 4.7 & 5.4 & 5.6 & 6.2 & 5.7 & 5.9 & 6.7 \\
\hline $\mathrm{MgO}$ & 1.1 & 1.1 & 1.2 & 0.9 & 0.8 & 0.5 & 0.6 & 0.5 & 0.3 & 0.4 \\
\hline $\mathrm{FeO}$ & 5.5 & 5.4 & 5.5 & 6.2 & 6.7 & 6.9 & 2.2 & 2.0 & 2.4 & 2.7 \\
\hline $\mathrm{CaO}$ & 1.1 & 1.2 & 1.2 & 1.2 & 0.8 & 0.8 & 0.7 & 0.8 & 0.2 & 0.2 \\
\hline $\mathrm{Na}_{2} \mathrm{O}$ & 1.4 & 1.4 & 1.3 & 1.3 & 1.5 & 1.6 & 1.8 & 1.7 & 1.8 & 2.1 \\
\hline $\mathrm{K}_{2} \mathrm{O}$ & 1.3 & 1.3 & 1.3 & 1.5 & 1.1 & 1.0 & 0.8 & 0.7 & 0.8 & 0.9 \\
\hline$N$ & 147 & 141 & 131 & 85 & 49 & 32 & 22 & 20 & 14 & 9 \\
\hline
\end{tabular}


Table A.2. (continued)

\begin{tabular}{|c|c|c|c|c|c|c|c|c|c|c|}
\hline Depth (km) & 5 & 10 & 15 & 20 & 25 & 30 & 35 & 40 & 45 & 50 \\
\hline $\mathrm{T}\left({ }^{\circ} \mathrm{C}\right)$ & 62 & 101 & 136 & 168 & 198 & 227 & 256 & 284 & 312 & 340 \\
\hline P (kbar) & 1.6 & 3.2 & 4.9 & 6.5 & 8.1 & 9.7 & 11.3 & 12.9 & 14.6 & 16.2 \\
\hline \multicolumn{11}{|c|}{$V_{p}=6.3 \mathrm{~km} / \mathrm{s}$} \\
\hline Mean & & & & & & & & & & \\
\hline $\mathrm{SiO}_{2}$ & 73.6 & 73.8 & 74.2 & 74.1 & 74.1 & 75.5 & 76.1 & 76.3 & 77.5 & 76.3 \\
\hline $\mathrm{Al}_{2} \mathrm{O}_{3}$ & 8.7 & 8.4 & 8.3 & 8.5 & 8.6 & 7.8 & 7.4 & 7.1 & 6.0 & 7.2 \\
\hline $\mathrm{MgO}$ & 2.9 & 2.9 & 2.7 & 2.5 & 2.1 & 2.0 & 2.0 & 1.9 & 1.6 & 1.3 \\
\hline $\mathrm{FeO}$ & 6.9 & 7.3 & 7.0 & 7.2 & 7.8 & 7.3 & 7.4 & 7.6 & 8.0 & 9.3 \\
\hline $\mathrm{CaO}$ & 2.5 & 2.3 & 2.3 & 2.2 & 2.1 & 2.0 & 1.9 & 1.9 & 2.0 & 1.4 \\
\hline $\mathrm{Na}_{2} \mathrm{O}$ & 2.5 & 2.5 & 2.5 & 2.6 & 2.6 & 2.4 & 2.3 & 2.3 & 2.1 & 2.1 \\
\hline $\mathrm{K}_{2} \mathrm{O}$ & 2.9 & 2.9 & 3.0 & 3.0 & 2.8 & 2.9 & 2.9 & 2.9 & 3.0 & 2.4 \\
\hline \multicolumn{11}{|l|}{ Std. Dev. } \\
\hline $\mathrm{SiO}_{2}$ & 8.1 & 8.0 & 8.1 & 7.6 & 8.0 & 8.2 & 7.7 & 8.0 & 6.2 & 6.7 \\
\hline $\mathrm{Al}_{2} \mathrm{O}_{3}$ & 7.0 & 7.0 & 7.0 & 6.4 & 6.6 & 6.7 & 6.3 & 6.5 & 4.8 & 5.4 \\
\hline $\mathrm{MgO}$ & 1.9 & 1.9 & 1.7 & 1.7 & 1.2 & 1.1 & 1.1 & 1.1 & 0.9 & 0.8 \\
\hline $\mathrm{FeO}$ & 5.6 & 5.8 & 5.7 & 5.8 & 5.8 & 5.4 & 5.5 & 5.6 & 6.2 & 6.7 \\
\hline $\mathrm{CaO}$ & 1.6 & 1.4 & 1.4 & 1.3 & 1.2 & 1.1 & 1.1 & 1.1 & 1.2 & 0.8 \\
\hline $\mathrm{Na}_{2} \mathrm{O}$ & 1.8 & 1.8 & 1.8 & 1.7 & 1.7 & 1.8 & 1.7 & 1.7 & 1.3 & 1.5 \\
\hline $\mathrm{K}_{2} \mathrm{O}$ & 1.3 & 1.4 & 1.4 & 1.4 & 1.4 & 1.3 & 1.3 & 1.4 & 1.5 & 1.1 \\
\hline$N$ & 269 & 237 & 214 & 190 & 162 & 152 & 144 & 124 & 81 & 49 \\
\hline \multicolumn{11}{|c|}{$V_{p}=6.4 \mathrm{~km} / \mathrm{s}$} \\
\hline Mean & & & & & & & & & & \\
\hline $\mathrm{SiO}_{2}$ & 67.4 & 68.0 & 68.5 & 70.2 & 72.0 & 72.8 & 73.5 & 73.6 & 73.9 & 74.4 \\
\hline $\mathrm{Al}_{2} \mathrm{O}_{3}$ & 12.9 & 12.7 & 12.4 & 11.2 & 9.9 & 9.5 & 8.7 & 8.8 & 8.7 & 8.4 \\
\hline $\mathrm{MgO}$ & 3.7 & 3.6 & 3.3 & 3.3 & 3.1 & 3.0 & 2.8 & 2.7 & 2.4 & 2.0 \\
\hline $\mathrm{FeO}$ & 6.8 & 6.7 & 7.0 & 7.0 & 6.7 & 6.7 & 7.0 & 7.0 & 7.3 & 7.8 \\
\hline $\mathrm{CaO}$ & 3.2 & 3.0 & 2.9 & 2.6 & 2.6 & 2.5 & 2.4 & 2.3 & 2.2 & 2.1 \\
\hline $\mathrm{Na}_{2} \mathrm{O}$ & 3.4 & 3.4 & 3.3 & 3.0 & 2.8 & 2.7 & 2.6 & 2.7 & 2.6 & 2.5 \\
\hline $\mathrm{K}_{2} \mathrm{O}$ & 2.7 & 2.7 & 2.7 & 2.7 & 2.9 & 2.9 & 2.9 & 3.0 & 2.9 & 2.8 \\
\hline \multicolumn{11}{|l|}{ Std. Dev. } \\
\hline $\mathrm{SiO}_{2}$ & 9.7 & 9.5 & 9.5 & 9.6 & 9.4 & 9.2 & 8.8 & 8.9 & 7.8 & 8.1 \\
\hline $\mathrm{Al}_{2} \mathrm{O}_{3}$ & 8.5 & 8.5 & 8.5 & 8.2 & 8.1 & 7.8 & 7.5 & 7.7 & 6.6 & 6.6 \\
\hline $\mathrm{MgO}$ & 2.5 & 2.4 & 2.2 & 2.0 & 2.0 & 1.9 & 1.9 & 1.7 & 1.6 & 1.2 \\
\hline $\mathrm{FeO}$ & 5.1 & 5.3 & 5.3 & 5.0 & 5.1 & 5.2 & 5.7 & 5.7 & 5.8 & 5.8 \\
\hline $\mathrm{CaO}$ & 2.0 & 1.8 & 1.8 & 1.6 & 1.6 & 1.6 & 1.6 & 1.4 & 1.3 & 1.2 \\
\hline $\mathrm{Na}_{2} \mathrm{O}$ & 2.2 & 2.2 & 2.2 & 2.2 & 2.1 & 2.0 & 1.9 & 2.0 & 1.7 & 1.7 \\
\hline $\mathrm{K}_{2} \mathrm{O}$ & 1.2 & 1.2 & 1.2 & 1.2 & 1.3 & 1.3 & 1.4 & 1.4 & 1.4 & 1.4 \\
\hline$N$ & 284 & 263 & 247 & 279 & 286 & 276 & 252 & 213 & 186 & 164 \\
\hline \multicolumn{11}{|c|}{$V_{p}=6.5 \mathrm{~km} / \mathrm{s}$} \\
\hline Mean & & & & & & & & & & \\
\hline $\mathrm{SiO}_{2}$ & 61.5 & 62.4 & 63.3 & 64.5 & 65.5 & 66.3 & 67.3 & 68.1 & 69.9 & 71.3 \\
\hline $\mathrm{Al}_{2} \mathrm{O}_{3}$ & 16.3 & 15.9 & 15.2 & 14.4 & 13.8 & 13.6 & 13.1 & 12.6 & 11.4 & 10.4 \\
\hline $\mathrm{MgO}$ & 4.4 & 4.1 & 4.2 & 4.2 & 4.2 & 3.7 & 3.6 & 3.4 & 3.2 & 3.1 \\
\hline $\mathrm{FeO}$ & 7.7 & 7.7 & 7.8 & 7.6 & 7.4 & 7.2 & 6.9 & 7.0 & 7.1 & 6.8 \\
\hline $\mathrm{CaO}$ & 3.9 & 3.7 & 3.5 & 3.2 & 3.1 & 3.1 & 3.0 & 2.9 & 2.6 & 2.6 \\
\hline $\mathrm{Na}_{2} \mathrm{O}$ & 3.9 & 3.9 & 3.8 & 3.7 & 3.6 & 3.5 & 3.5 & 3.3 & 3.1 & 2.9 \\
\hline $\mathrm{K}_{2} \mathrm{O}$ & 2.2 & 2.3 & 2.3 & 2.4 & 2.5 & 2.6 & 2.7 & 2.7 & 2.7 & 2.9 \\
\hline \multicolumn{11}{|l|}{ Std. Dev. } \\
\hline $\mathrm{SiO}_{2}$ & 9.5 & 10.2 & 10.1 & 11.0 & 11.2 & 10.7 & 10.2 & 10.1 & 10.2 & 10.2 \\
\hline $\mathrm{Al}_{2} \mathrm{O}_{3}$ & 8.4 & 8.5 & 8.4 & 9.2 & 9.2 & 8.8 & 8.7 & 8.5 & 8.5 & 8.5 \\
\hline $\mathrm{MgO}$ & 2.8 & 2.8 & 2.8 & 2.7 & 2.7 & 2.4 & 2.4 & 2.2 & 2.0 & 2.0 \\
\hline $\mathrm{FeO}$ & 5.6 & 5.6 & 5.7 & 5.7 & 5.7 & 5.6 & 5.3 & 5.3 & 5.2 & 5.1 \\
\hline $\mathrm{CaO}$ & 2.6 & 2.5 & 2.4 & 2.0 & 2.0 & 2.0 & 1.8 & 1.8 & 1.6 & 1.6 \\
\hline
\end{tabular}


Table A.2. (continued)

\begin{tabular}{|c|c|c|c|c|c|c|c|c|c|c|}
\hline Depth $(\mathrm{km})$ & 5 & 10 & 15 & 20 & 25 & 30 & 35 & 40 & 45 & 50 \\
\hline $\mathrm{T}\left({ }^{\circ} \mathrm{C}\right)$ & 62 & 101 & 136 & 168 & 198 & 227 & 256 & 284 & 312 & 340 \\
\hline P (kbar) & 1.6 & 3.2 & 4.9 & 6.5 & 8.1 & 9.7 & 11.3 & 12.9 & 14.6 & 16.2 \\
\hline $\mathrm{Na}_{2} \mathrm{O}$ & 2.2 & 2.2 & 2.2 & 2.4 & 2.3 & 2.2 & 2.2 & 2.2 & 2.2 & 2.2 \\
\hline $\mathrm{K}_{2} \mathrm{O}$ & 1.1 & 1.1 & 1.1 & 1.1 & 1.2 & 1.2 & 1.2 & 1.2 & 1.2 & 1.3 \\
\hline$N$ & 371 & 354 & 354 & 337 & 343 & 301 & 272 & 271 & 284 & 295 \\
\hline \multicolumn{11}{|c|}{$V_{p}=6.6 \mathrm{~km} / \mathrm{s}$} \\
\hline Mean & & & & & & & & & & \\
\hline $\mathrm{SiO}_{2}$ & 59.0 & 59.4 & 59.5 & 59.4 & 59.4 & 60.3 & 60.8 & 62.7 & 63.9 & 64.9 \\
\hline $\mathrm{Al}_{2} \mathrm{O}_{3}$ & 17.1 & 16.9 & 16.9 & 17.3 & 17.5 & 16.9 & 16.8 & 15.6 & 14.8 & 14.2 \\
\hline $\mathrm{MgO}$ & 5.5 & 5.3 & 5.2 & 5.0 & 4.7 & 4.6 & 4.3 & 4.2 & 4.2 & 4.2 \\
\hline $\mathrm{FeO}$ & 8.1 & 8.2 & 8.0 & 8.0 & 8.1 & 8.1 & 8.1 & 7.9 & 7.8 & 7.5 \\
\hline $\mathrm{CaO}$ & 4.6 & 4.5 & 4.4 & 4.2 & 4.1 & 3.9 & 3.7 & 3.5 & 3.1 & 3.0 \\
\hline $\mathrm{Na}_{2} \mathrm{O}$ & 3.9 & 3.9 & 4.0 & 4.1 & 4.2 & 4.1 & 4.1 & 3.9 & 3.8 & 3.7 \\
\hline $\mathrm{K}_{2} \mathrm{O}$ & 1.9 & 1.9 & 2.0 & 2.0 & 2.1 & 2.2 & 2.2 & 2.3 & 2.4 & 2.5 \\
\hline \multicolumn{11}{|l|}{ Std. Dev. } \\
\hline $\mathrm{SiO}_{2}$ & 9.9 & 10.2 & 10.3 & 10.2 & 10.4 & 10.3 & 10.3 & 10.7 & 11.6 & 11.7 \\
\hline $\mathrm{Al}_{2} \mathrm{O}_{3}$ & 8.4 & 8.6 & 8.6 & 8.6 & 8.6 & 8.7 & 8.7 & 8.8 & 9.5 & 9.5 \\
\hline $\mathrm{MgO}$ & 3.4 & 3.3 & 3.2 & 3.3 & 3.1 & 3.0 & 2.8 & 2.8 & 2.7 & 2.7 \\
\hline $\mathrm{FeO}$ & 5.6 & 5.6 & 5.8 & 5.8 & 5.7 & 5.8 & 5.7 & 5.7 & 5.6 & 5.7 \\
\hline $\mathrm{CaO}$ & 2.9 & 2.9 & 2.9 & 2.8 & 2.7 & 2.6 & 2.4 & 2.4 & 2.0 & 2.0 \\
\hline $\mathrm{Na}_{2} \mathrm{O}$ & 2.2 & 2.3 & 2.3 & 2.2 & 2.2 & 2.2 & 2.2 & 2.3 & 2.4 & 2.4 \\
\hline $\mathrm{K}_{2} \mathrm{O}$ & 1.1 & 1.1 & 1.1 & 1.1 & 1.1 & 1.1 & 1.1 & 1.1 & 1.1 & 1.2 \\
\hline$N$ & 489 & 476 & 468 & 438 & 426 & 395 & 387 & 377 & 358 & 353 \\
\hline \multicolumn{11}{|c|}{$V_{p}=6.7 \mathrm{~km} / \mathrm{s}$} \\
\hline Mean & & & & & & & & & & \\
\hline $\mathrm{SiO}_{2}$ & 56.5 & 56.9 & 56.9 & 56.8 & 57.3 & 58.1 & 58.4 & 58.4 & 58.2 & 58.1 \\
\hline $\mathrm{Al}_{2} \mathrm{O}_{3}$ & 17.9 & 17.8 & 17.9 & 18.3 & 18.2 & 17.6 & 17.5 & 17.7 & 17.9 & 18.1 \\
\hline $\mathrm{MgO}$ & 6.5 & 6.3 & 6.0 & 5.7 & 5.5 & 5.5 & 5.4 & 5.3 & 5.1 & 4.9 \\
\hline $\mathrm{FeO}$ & 8.4 & 8.4 & 8.4 & 8.4 & 8.2 & 8.2 & 8.2 & 8.3 & 8.4 & 8.5 \\
\hline $\mathrm{CaO}$ & 5.2 & 5.1 & 5.2 & 5.0 & 4.9 & 4.6 & 4.4 & 4.3 & 4.1 & 4.0 \\
\hline $\mathrm{Na}_{2} \mathrm{O}$ & 3.9 & 3.9 & 4.0 & 4.1 & 4.1 & 4.1 & 4.1 & 4.2 & 4.3 & 4.4 \\
\hline $\mathrm{K}_{2} \mathrm{O}$ & 1.6 & 1.7 & 1.7 & 1.7 & 1.8 & 1.9 & 1.9 & 2.0 & 2.0 & 2.1 \\
\hline \multicolumn{11}{|l|}{ Std. Dev. } \\
\hline $\mathrm{SiO}_{2}$ & 10.1 & 10.2 & 10.2 & 10.1 & 10.2 & 10.6 & 10.9 & 11.1 & 11.1 & 11.3 \\
\hline $\mathrm{Al}_{2} \mathrm{O}_{3}$ & 8.4 & 8.4 & 8.6 & 8.3 & 8.4 & 8.8 & 8.9 & 8.9 & 8.9 & 8.9 \\
\hline $\mathrm{MgO}$ & 3.6 & 3.5 & 3.4 & 3.4 & 3.4 & 3.4 & 3.4 & 3.2 & 3.2 & 3.1 \\
\hline $\mathrm{FeO}$ & 5.4 & 5.5 & 5.4 & 5.6 & 5.4 & 5.6 & 5.7 & 5.8 & 5.9 & 6.0 \\
\hline $\mathrm{CaO}$ & 3.3 & 3.2 & 3.2 & 3.1 & 3.0 & 2.9 & 2.9 & 2.9 & 2.7 & 2.6 \\
\hline $\mathrm{Na}_{2} \mathrm{O}$ & 2.3 & 2.3 & 2.3 & 2.2 & 2.2 & 2.3 & 2.4 & 2.4 & 2.3 & 2.3 \\
\hline $\mathrm{K}_{2} \mathrm{O}$ & 1.0 & 1.0 & 1.0 & 1.1 & 1.0 & 1.1 & 1.1 & 1.1 & 1.1 & 1.1 \\
\hline$N$ & 583 & 578 & 568 & 558 & 529 & 543 & 521 & 489 & 469 & 454 \\
\hline \multicolumn{11}{|c|}{$V_{p}=6.8 \mathrm{~km} / \mathrm{s}$} \\
\hline \multicolumn{11}{|l|}{ Mean } \\
\hline $\mathrm{SiO}_{2}$ & 55.0 & 55.1 & 55.3 & 55.6 & 56.0 & 55.9 & 56.2 & 56.2 & 56.2 & 56.2 \\
\hline $\mathrm{Al}_{2} \mathrm{O}_{3}$ & 18.3 & 18.3 & 18.3 & 18.1 & 18.0 & 18.2 & 18.1 & 18.3 & 18.4 & 18.8 \\
\hline $\mathrm{MgO}$ & 7.6 & 7.6 & 7.4 & 7.3 & 7.2 & 6.8 & 6.6 & 6.2 & 5.8 & 5.7 \\
\hline $\mathrm{FeO}$ & 8.0 & 8.0 & 8.0 & 8.0 & 8.2 & 8.2 & 8.4 & 8.6 & 8.7 & 8.6 \\
\hline $\mathrm{CaO}$ & 5.8 & 5.7 & 5.6 & 5.6 & 5.3 & 5.4 & 5.1 & 5.1 & 5.0 & 4.8 \\
\hline $\mathrm{Na}_{2} \mathrm{O}$ & 3.8 & 3.9 & 3.9 & 3.9 & 3.9 & 4.0 & 4.0 & 4.1 & 4.1 & 4.3 \\
\hline $\mathrm{K}_{2} \mathrm{O}$ & 1.4 & 1.5 & 1.5 & 1.5 & 1.6 & 1.6 & 1.6 & 1.6 & 1.7 & 1.7 \\
\hline
\end{tabular}


Table A.2. (continued)

\begin{tabular}{|c|c|c|c|c|c|c|c|c|c|c|}
\hline Depth (km) & 5 & 10 & 15 & 20 & 25 & 30 & 35 & 40 & 45 & 50 \\
\hline $\mathrm{T}\left({ }^{\circ} \mathrm{C}\right)$ & 62 & 101 & 136 & 168 & 198 & 227 & 256 & 284 & 312 & 340 \\
\hline P (kbar) & 1.6 & 3.2 & 4.9 & 6.5 & 8.1 & 9.7 & 11.3 & 12.9 & 14.6 & 16.2 \\
\hline \multicolumn{11}{|l|}{ Std. Dev. } \\
\hline $\mathrm{SiO}_{2}$ & 10.0 & 9.9 & 10.1 & 10.4 & 10.3 & 10.4 & 10.7 & 10.6 & 10.6 & 10.8 \\
\hline $\mathrm{Al}_{2} \mathrm{O}_{3}$ & 8.4 & 8.4 & 8.5 & 8.6 & 8.4 & 8.5 & 8.6 & 8.7 & 8.4 & 8.4 \\
\hline $\mathrm{MgO}$ & 3.9 & 3.9 & 3.8 & 3.6 & 3.6 & 3.6 & 3.6 & 3.4 & 3.4 & 3.3 \\
\hline $\mathrm{FeO}$ & 5.3 & 5.3 & 5.3 & 5.3 & 5.4 & 5.4 & 5.5 & 5.6 & 5.7 & 5.7 \\
\hline $\mathrm{CaO}$ & 3.8 & 3.6 & 3.6 & 3.5 & 3.5 & 3.4 & 3.2 & 3.1 & 3.2 & 3.0 \\
\hline $\mathrm{Na}_{2} \mathrm{O}$ & 2.4 & 2.3 & 2.4 & 2.4 & 2.3 & 2.3 & 2.3 & 2.4 & 2.3 & 2.3 \\
\hline $\mathrm{K}_{2} \mathrm{O}$ & 0.9 & 0.9 & 0.9 & 0.9 & 1.0 & 1.0 & 1.0 & 1.0 & 1.0 & 1.0 \\
\hline$N$ & 666 & 674 & 671 & 663 & 638 & 645 & 600 & 602 & 593 & 576 \\
\hline \multicolumn{11}{|c|}{$V_{p}=6.9 \mathrm{~km} / \mathrm{s}$} \\
\hline Mean & & & & & & & & & & \\
\hline $\mathrm{SiO}_{2}$ & 54.6 & 54.8 & 54.9 & 55.4 & 55.3 & 55.2 & 55.3 & 55.7 & 56.0 & 55.9 \\
\hline $\mathrm{Al}_{2} \mathrm{O}_{3}$ & 17.6 & 17.7 & 17.8 & 17.4 & 17.6 & 17.8 & 18.1 & 17.9 & 17.9 & 18.0 \\
\hline $\mathrm{MgO}$ & 9.2 & 9.0 & 8.9 & 8.7 & 8.5 & 8.3 & 7.7 & 7.6 & 7.4 & 7.2 \\
\hline $\mathrm{FeO}$ & 7.1 & 7.0 & 7.0 & 7.1 & 7.3 & 7.5 & 7.8 & 7.9 & 7.7 & 7.9 \\
\hline $\mathrm{CaO}$ & 6.5 & 6.6 & 6.4 & 6.4 & 6.2 & 6.0 & 5.9 & 5.7 & 5.7 & 5.6 \\
\hline $\mathrm{Na}_{2} \mathrm{O}$ & 3.5 & 3.5 & 3.6 & 3.5 & 3.6 & 3.7 & 3.7 & 3.7 & 3.8 & 3.8 \\
\hline $\mathrm{K}_{2} \mathrm{O}$ & 1.4 & 1.5 & 1.5 & 1.5 & 1.5 & 1.5 & 1.5 & 1.5 & 1.5 & 1.5 \\
\hline \multicolumn{11}{|l|}{ Std. Dev. } \\
\hline $\mathrm{SiO}_{2}$ & 9.2 & 9.1 & 9.2 & 9.4 & 9.6 & 9.5 & 9.6 & 9.8 & 10.0 & 10.0 \\
\hline $\mathrm{Al}_{2} \mathrm{O}_{3}$ & 8.1 & 8.1 & 8.1 & 8.3 & 8.3 & 8.1 & 8.2 & 8.3 & 8.4 & 8.3 \\
\hline $\mathrm{MgO}$ & 4.8 & 4.7 & 4.6 & 4.6 & 4.5 & 4.3 & 3.9 & 3.9 & 3.8 & 3.7 \\
\hline $\mathrm{FeO}$ & 4.8 & 4.8 & 4.8 & 4.7 & 5.0 & 5.0 & 5.2 & 5.1 & 5.1 & 5.1 \\
\hline $\mathrm{CaO}$ & 4.2 & 4.1 & 4.0 & 4.0 & 3.9 & 3.8 & 3.7 & 3.6 & 3.5 & 3.5 \\
\hline $\mathrm{Na}_{2} \mathrm{O}$ & 2.2 & 2.2 & 2.2 & 2.2 & 2.2 & 2.2 & 2.2 & 2.2 & 2.3 & 2.2 \\
\hline $\mathrm{K}_{2} \mathrm{O}$ & 0.9 & 0.9 & 0.9 & 0.9 & 0.9 & 0.9 & 0.9 & 0.9 & 0.9 & 0.9 \\
\hline$N$ & 676 & 699 & 671 & 690 & 697 & 686 & 677 & 676 & 679 & 649 \\
\hline \multicolumn{11}{|c|}{$V_{p}=7.0 \mathrm{~km} / \mathrm{s}$} \\
\hline Mean & & & & & & & & & & \\
\hline $\mathrm{SiO}_{2}$ & 53.5 & 53.6 & 53.8 & 54.1 & 54.2 & 54.3 & 54.6 & 54.7 & 55.0 & 55.3 \\
\hline $\mathrm{Al}_{2} \mathrm{O}_{3}$ & 17.1 & 17.3 & 17.3 & 17.2 & 17.4 & 17.4 & 17.5 & 17.6 & 17.5 & 17.4 \\
\hline $\mathrm{MgO}$ & 10.7 & 10.4 & 10.3 & 10.0 & 9.8 & 9.8 & 9.4 & 9.4 & 9.1 & 8.9 \\
\hline $\mathrm{FeO}$ & 6.9 & 6.8 & 6.8 & 6.9 & 7.0 & 7.0 & 6.9 & 6.9 & 7.0 & 7.1 \\
\hline $\mathrm{CaO}$ & 7.2 & 7.2 & 7.2 & 7.1 & 6.9 & 6.6 & 6.7 & 6.4 & 6.4 & 6.4 \\
\hline $\mathrm{Na}_{2} \mathrm{O}$ & 3.2 & 3.3 & 3.3 & 3.3 & 3.4 & 3.4 & 3.5 & 3.5 & 3.5 & 3.5 \\
\hline $\mathrm{K}_{2} \mathrm{O}$ & 1.3 & 1.3 & 1.4 & 1.4 & 1.4 & 1.4 & 1.4 & 1.5 & 1.5 & 1.5 \\
\hline \multicolumn{11}{|l|}{ Std. Dev. } \\
\hline $\mathrm{SiO}_{2}$ & 8.7 & 8.8 & 8.7 & 8.8 & 9.0 & 9.2 & 9.1 & 9.3 & 9.4 & 9.5 \\
\hline $\mathrm{Al}_{2} \mathrm{O}_{3}$ & 7.8 & 7.8 & 7.8 & 7.8 & 8.0 & 8.0 & 8.0 & 8.0 & 8.2 & 8.1 \\
\hline $\mathrm{MgO}$ & 5.4 & 5.4 & 5.4 & 5.4 & 5.3 & 5.1 & 5.0 & 5.0 & 4.7 & 4.6 \\
\hline $\mathrm{FeO}$ & 4.7 & 4.6 & 4.5 & 4.6 & 4.6 & 4.7 & 4.6 & 4.6 & 4.5 & 4.6 \\
\hline $\mathrm{CaO}$ & 4.6 & 4.6 & 4.6 & 4.6 & 4.3 & 4.2 & 4.2 & 4.1 & 3.9 & 3.9 \\
\hline $\mathrm{Na}_{2} \mathrm{O}$ & 2.0 & 2.0 & 2.0 & 2.0 & 2.1 & 2.1 & 2.1 & 2.1 & 2.1 & 2.1 \\
\hline $\mathrm{K}_{2} \mathrm{O}$ & 0.9 & 0.9 & 0.9 & 0.9 & 0.9 & 0.9 & 0.9 & 0.9 & 0.9 & 0.9 \\
\hline$N$ & 627 & 626 & 635 & 642 & 664 & 669 & 719 & 709 & 715 & 724 \\
\hline \multicolumn{11}{|c|}{$V_{p}=7.1 \mathrm{~km} / \mathrm{s}$} \\
\hline Mean & & & & & & & & & & \\
\hline $\mathrm{SiO}_{2}$ & 51.4 & 51.5 & 51.8 & 52.0 & 52.2 & 52.4 & 52.8 & 53.1 & 53.4 & 54.0 \\
\hline $\mathrm{Al}_{2} \mathrm{O}_{3}$ & 17.7 & 17.7 & 17.7 & 17.8 & 17.7 & 17.8 & 17.6 & 17.6 & 17.4 & 17.1 \\
\hline $\mathrm{MgO}$ & 12.0 & 12.1 & 11.6 & 11.3 & 11.2 & 11.0 & 11.0 & 10.7 & 10.4 & 10.3 \\
\hline
\end{tabular}


Table A.2. (continued)

\begin{tabular}{|c|c|c|c|c|c|c|c|c|c|c|}
\hline Depth (km) & 5 & 10 & 15 & 20 & 25 & 30 & 35 & 40 & 45 & 50 \\
\hline $\mathrm{T}\left({ }^{\circ} \mathrm{C}\right)$ & 62 & 101 & 136 & 168 & 198 & 227 & 256 & 284 & 312 & 340 \\
\hline P (kbar) & 1.6 & 3.2 & 4.9 & 6.5 & 8.1 & 9.7 & 11.3 & 12.9 & 14.6 & 16.2 \\
\hline $\mathrm{FeO}$ & 7.1 & 7.1 & 7.3 & 7.2 & 7.2 & 7.0 & 7.0 & 6.8 & 7.1 & 7.1 \\
\hline $\mathrm{CaO}$ & 7.4 & 7.2 & 7.2 & 7.2 & 7.2 & 7.2 & 7.1 & 7.1 & 7.1 & 6.9 \\
\hline $\mathrm{Na}_{2} \mathrm{O}$ & 3.3 & 3.3 & 3.3 & 3.3 & 3.3 & 3.4 & 3.4 & 3.4 & 3.4 & 3.3 \\
\hline $\mathrm{K}_{2} \mathrm{O}$ & 1.1 & 1.1 & 1.1 & 1.1 & 1.2 & 1.2 & 1.3 & 1.3 & 1.3 & 1.3 \\
\hline \multicolumn{11}{|l|}{ Std. Dev. } \\
\hline $\mathrm{SiO}_{2}$ & 8.7 & 8.9 & 9.1 & 9.1 & 9.1 & 9.2 & 9.1 & 9.2 & 9.2 & 9.4 \\
\hline $\mathrm{Al}_{2} \mathrm{O}_{3}$ & 7.7 & 7.8 & 7.9 & 7.8 & 7.8 & 7.9 & 7.9 & 7.8 & 7.8 & 7.9 \\
\hline $\mathrm{MgO}$ & 5.8 & 5.8 & 5.5 & 5.4 & 5.4 & 5.5 & 5.5 & 5.5 & 5.4 & 5.3 \\
\hline $\mathrm{FeO}$ & 5.0 & 5.0 & 5.0 & 5.0 & 4.9 & 4.8 & 4.7 & 4.7 & 4.8 & 4.8 \\
\hline $\mathrm{CaO}$ & 5.1 & 5.0 & 4.9 & 4.7 & 4.7 & 4.7 & 4.7 & 4.6 & 4.6 & 4.4 \\
\hline $\mathrm{Na}_{2} \mathrm{O}$ & 2.0 & 2.1 & 2.1 & 2.1 & 2.1 & 2.1 & 2.0 & 2.0 & 2.0 & 2.0 \\
\hline $\mathrm{K}_{2} \mathrm{O}$ & 0.8 & 0.8 & 0.8 & 0.8 & 0.8 & 0.8 & 0.8 & 0.8 & 0.9 & 0.9 \\
\hline$N$ & 567 & 569 & 582 & 582 & 606 & 628 & 674 & 676 & 680 & 690 \\
\hline \multicolumn{11}{|c|}{$V_{p}=7.2 \mathrm{~km} / \mathrm{s}$} \\
\hline Mean & & & & & & & & & & \\
\hline $\mathrm{SiO}_{2}$ & 50.2 & 50.5 & 50.6 & 50.8 & 51.1 & 51.3 & 51.3 & 51.6 & 51.6 & 51.9 \\
\hline $\mathrm{Al}_{2} \mathrm{O}_{3}$ & 17.9 & 17.7 & 17.6 & 17.5 & 17.5 & 17.5 & 17.6 & 17.6 & 17.8 & 17.8 \\
\hline $\mathrm{MgO}$ & 12.7 & 12.8 & 12.8 & 12.8 & 12.6 & 12.3 & 12.1 & 11.8 & 11.7 & 11.4 \\
\hline $\mathrm{FeO}$ & 7.3 & 7.3 & 7.4 & 7.2 & 7.0 & 7.0 & 7.2 & 7.1 & 7.2 & 7.1 \\
\hline $\mathrm{CaO}$ & 7.5 & 7.5 & 7.4 & 7.4 & 7.6 & 7.6 & 7.5 & 7.5 & 7.3 & 7.4 \\
\hline $\mathrm{Na}_{2} \mathrm{O}$ & 3.3 & 3.3 & 3.3 & 3.2 & 3.2 & 3.2 & 3.2 & 3.2 & 3.3 & 3.3 \\
\hline $\mathrm{K}_{2} \mathrm{O}$ & 1.1 & 1.0 & 1.0 & 1.0 & 1.1 & 1.1 & 1.1 & 1.1 & 1.1 & 1.1 \\
\hline \multicolumn{11}{|l|}{ Std. Dev. } \\
\hline $\mathrm{SiO}_{2}$ & 8.6 & 8.6 & 8.6 & 8.5 & 8.6 & 8.8 & 8.9 & 9.0 & 9.2 & 9.4 \\
\hline $\mathrm{Al}_{2} \mathrm{O}_{3}$ & 7.8 & 7.8 & 7.7 & 7.6 & 7.5 & 7.7 & 7.8 & 7.8 & 7.9 & 8.0 \\
\hline $\mathrm{MgO}$ & 6.2 & 6.2 & 6.0 & 6.0 & 6.0 & 6.0 & 5.9 & 5.8 & 5.6 & 5.6 \\
\hline $\mathrm{FeO}$ & 4.9 & 4.9 & 4.9 & 5.0 & 5.0 & 5.0 & 5.1 & 5.0 & 4.9 & 4.9 \\
\hline $\mathrm{CaO}$ & 5.2 & 5.2 & 5.1 & 5.0 & 5.1 & 5.1 & 5.0 & 5.0 & 4.9 & 4.8 \\
\hline $\mathrm{Na}_{2} \mathrm{O}$ & 2.0 & 2.0 & 2.0 & 2.0 & 2.0 & 2.0 & 2.0 & 2.0 & 2.0 & 2.1 \\
\hline $\mathrm{K}_{2} \mathrm{O}$ & 0.8 & 0.8 & 0.7 & 0.7 & 0.7 & 0.8 & 0.7 & 0.8 & 0.7 & 0.8 \\
\hline$N$ & 483 & 508 & 521 & 550 & 570 & 575 & 573 & 591 & 592 & 597 \\
\hline \multicolumn{11}{|c|}{$V_{p}=7.3 \mathrm{~km} / \mathrm{s}$} \\
\hline Mean & & & & & & & & & & \\
\hline $\mathrm{SiO}_{2}$ & 48.7 & 49.0 & 49.3 & 49.5 & 49.7 & 50.1 & 50.2 & 50.5 & 50.8 & 51.0 \\
\hline $\mathrm{Al}_{2} \mathrm{O}_{3}$ & 18.7 & 18.4 & 18.3 & 18.1 & 18.1 & 17.8 & 17.9 & 17.7 & 17.6 & 17.7 \\
\hline $\mathrm{MgO}$ & 12.8 & 12.9 & 13.1 & 13.1 & 12.8 & 12.8 & 12.5 & 12.5 & 12.7 & 12.5 \\
\hline $\mathrm{FeO}$ & 6.8 & 6.9 & 6.7 & 6.8 & 6.9 & 7.0 & 7.0 & 7.0 & 6.8 & 6.7 \\
\hline $\mathrm{CaO}$ & 8.8 & 8.7 & 8.5 & 8.5 & 8.3 & 8.2 & 8.3 & 8.1 & 7.9 & 8.0 \\
\hline $\mathrm{Na}_{2} \mathrm{O}$ & 3.3 & 3.2 & 3.2 & 3.1 & 3.2 & 3.1 & 3.2 & 3.1 & 3.1 & 3.1 \\
\hline $\mathrm{K}_{2} \mathrm{O}$ & 0.9 & 0.9 & 0.9 & 0.9 & 0.9 & 1.0 & 1.0 & 1.0 & 1.0 & 1.0 \\
\hline \multicolumn{11}{|l|}{ Std. Dev. } \\
\hline $\mathrm{SiO}_{2}$ & 8.1 & 8.1 & 8.2 & 8.2 & 8.4 & 8.4 & 8.7 & 8.5 & 8.6 & 8.5 \\
\hline $\mathrm{Al}_{2} \mathrm{O}_{3}$ & 7.8 & 7.8 & 7.7 & 7.7 & 7.8 & 7.7 & 7.9 & 7.8 & 7.7 & 7.7 \\
\hline $\mathrm{MgO}$ & 6.7 & 6.7 & 6.8 & 6.8 & 6.7 & 6.6 & 6.3 & 6.2 & 6.0 & 6.1 \\
\hline $\mathrm{FeO}$ & 4.5 & 4.4 & 4.5 & 4.7 & 4.8 & 4.8 & 4.8 & 4.8 & 4.8 & 4.8 \\
\hline $\mathrm{CaO}$ & 5.5 & 5.5 & 5.6 & 5.7 & 5.7 & 5.5 & 5.4 & 5.2 & 5.1 & 5.2 \\
\hline $\mathrm{Na}_{2} \mathrm{O}$ & 1.9 & 1.9 & 1.9 & 1.9 & 1.9 & 1.9 & 1.9 & 1.9 & 1.9 & 1.9 \\
\hline $\mathrm{K}_{2} \mathrm{O}$ & 0.7 & 0.7 & 0.7 & 0.7 & 0.7 & 0.7 & 0.7 & 0.7 & 0.7 & 0.7 \\
\hline$N$ & 420 & 435 & 461 & 480 & 469 & 490 & 477 & 510 & 533 & 573 \\
\hline
\end{tabular}


Table A.2. (continued)

\begin{tabular}{|c|c|c|c|c|c|c|c|c|c|c|}
\hline Depth (km) & 5 & 10 & 15 & 20 & 25 & 30 & 35 & 40 & 45 & 50 \\
\hline $\mathrm{T}\left({ }^{\circ} \mathrm{C}\right)$ & 62 & 101 & 136 & 168 & 198 & 227 & 256 & 284 & 312 & 340 \\
\hline P (kbar) & 1.6 & 3.2 & 4.9 & 6.5 & 8.1 & 9.7 & 11.3 & 12.9 & 14.6 & 16.2 \\
\hline \multicolumn{11}{|c|}{$V_{p}=7.4 \mathrm{~km} / \mathrm{s}$} \\
\hline Mean & & & & & & & & & & \\
\hline $\mathrm{SiO}_{2}$ & 47.3 & 47.3 & 47.5 & 47.7 & 47.8 & 48.3 & 48.9 & 49.3 & 49.9 & 50.1 \\
\hline $\mathrm{Al}_{2} \mathrm{O}_{3}$ & 19.3 & 19.5 & 19.4 & 19.5 & 19.3 & 18.9 & 18.6 & 18.2 & 17.9 & 17.8 \\
\hline $\mathrm{MgO}$ & 13.7 & 13.4 & 13.3 & 13.0 & 12.9 & 13.2 & 13.0 & 13.0 & 13.1 & 13.1 \\
\hline $\mathrm{FeO}$ & 6.0 & 6.0 & 6.1 & 6.0 & 6.2 & 6.3 & 6.3 & 6.4 & 6.2 & 6.4 \\
\hline $\mathrm{CaO}$ & 9.7 & 9.7 & 9.7 & 9.7 & 9.5 & 9.3 & 9.2 & 9.2 & 8.9 & 8.7 \\
\hline $\mathrm{Na}_{2} \mathrm{O}$ & 3.2 & 3.2 & 3.2 & 3.2 & 3.3 & 3.2 & 3.1 & 3.1 & 3.0 & 3.0 \\
\hline $\mathrm{K}_{2} \mathrm{O}$ & 0.8 & 0.9 & 0.9 & 0.9 & 0.9 & 0.9 & 0.9 & 0.9 & 1.0 & 0.9 \\
\hline \multicolumn{11}{|l|}{ Std. Dev. } \\
\hline $\mathrm{SiO}_{2}$ & 7.3 & 7.4 & 7.4 & 7.5 & 7.6 & 7.5 & 7.7 & 7.6 & 7.8 & 7.8 \\
\hline $\mathrm{Al}_{2} \mathrm{O}_{3}$ & 7.3 & 7.3 & 7.2 & 7.2 & 7.4 & 7.3 & 7.3 & 7.4 & 7.3 & 7.3 \\
\hline $\mathrm{MgO}$ & 7.5 & 7.4 & 7.5 & 7.3 & 7.3 & 7.1 & 6.8 & 6.8 & 6.8 & 6.7 \\
\hline $\mathrm{FeO}$ & 4.1 & 4.1 & 4.1 & 4.1 & 4.1 & 4.1 & 4.1 & 4.2 & 4.3 & 4.5 \\
\hline $\mathrm{CaO}$ & 5.8 & 5.8 & 5.9 & 5.8 & 5.8 & 5.7 & 5.5 & 5.5 & 5.5 & 5.6 \\
\hline $\mathrm{Na}_{2} \mathrm{O}$ & 1.8 & 1.8 & 1.8 & 1.8 & 1.8 & 1.7 & 1.8 & 1.8 & 1.8 & 1.7 \\
\hline $\mathrm{K}_{2} \mathrm{O}$ & 0.7 & 0.7 & 0.7 & 0.7 & 0.7 & 0.7 & 0.7 & 0.7 & 0.7 & 0.7 \\
\hline$N$ & 349 & 347 & 352 & 352 & 354 & 383 & 400 & 438 & 463 & 477 \\
\hline \multicolumn{11}{|c|}{$V_{p}=7.5 \mathrm{~km} / \mathrm{s}$} \\
\hline Mean & & & & & & & & & & \\
\hline $\mathrm{SiO}_{2}$ & 47.4 & 47.5 & 47.9 & 48.2 & 48.5 & 48.4 & 48.4 & 48.1 & 48.1 & 48.2 \\
\hline $\mathrm{Al}_{2} \mathrm{O}_{3}$ & 18.4 & 18.5 & 18.3 & 18.1 & 17.8 & 18.0 & 18.0 & 18.3 & 18.7 & 18.6 \\
\hline $\mathrm{MgO}$ & 15.0 & 14.6 & 14.2 & 14.3 & 14.4 & 14.2 & 14.5 & 14.3 & 13.8 & 13.6 \\
\hline $\mathrm{FeO}$ & 5.8 & 5.8 & 6.0 & 6.0 & 6.0 & 6.0 & 6.0 & 6.0 & 6.0 & 6.1 \\
\hline $\mathrm{CaO}$ & 9.6 & 9.8 & 10.0 & 9.7 & 9.7 & 9.8 & 9.4 & 9.4 & 9.6 & 9.6 \\
\hline $\mathrm{Na}_{2} \mathrm{O}$ & 3.0 & 3.0 & 2.9 & 2.9 & 2.8 & 2.9 & 2.9 & 3.0 & 3.1 & 3.1 \\
\hline $\mathrm{K}_{2} \mathrm{O}$ & 0.8 & 0.8 & 0.8 & 0.8 & 0.8 & 0.8 & 0.8 & 0.9 & 0.9 & 0.9 \\
\hline \multicolumn{11}{|l|}{ Std. Dev. } \\
\hline $\mathrm{SiO}_{2}$ & 7.2 & 7.1 & 7.1 & 7.3 & 7.1 & 7.2 & 7.0 & 7.1 & 7.0 & 7.1 \\
\hline $\mathrm{Al}_{2} \mathrm{O}_{3}$ & 6.6 & 6.5 & 6.7 & 6.7 & 6.7 & 6.8 & 6.8 & 6.8 & 6.7 & 6.7 \\
\hline $\mathrm{MgO}$ & 8.0 & 8.0 & 7.7 & 7.5 & 7.4 & 7.3 & 7.4 & 7.5 & 7.6 & 7.6 \\
\hline $\mathrm{FeO}$ & 3.9 & 4.0 & 4.1 & 4.1 & 4.1 & 4.1 & 3.9 & 4.0 & 4.0 & 4.0 \\
\hline $\mathrm{CaO}$ & 6.3 & 6.3 & 6.2 & 6.0 & 5.9 & 5.9 & 5.9 & 6.0 & 6.0 & 6.0 \\
\hline $\mathrm{Na}_{2} \mathrm{O}$ & 1.8 & 1.8 & 1.8 & 1.8 & 1.8 & 1.8 & 1.8 & 1.8 & 1.7 & 1.7 \\
\hline $\mathrm{K}_{2} \mathrm{O}$ & 0.7 & 0.7 & 0.7 & 0.7 & 0.7 & 0.7 & 0.7 & 0.7 & 0.7 & 0.7 \\
\hline$N$ & 255 & 267 & 278 & 288 & 311 & 316 & 334 & 336 & 338 & 343 \\
\hline \multicolumn{11}{|c|}{$V_{p}=7.6 \mathrm{~km} / \mathrm{s}$} \\
\hline Mean & & & & & & & & & & \\
\hline $\mathrm{SiO}_{2}$ & 45.6 & 45.7 & 45.9 & 46.0 & 46.5 & 46.6 & 46.5 & 46.4 & 46.6 & 46.8 \\
\hline $\mathrm{Al}_{2} \mathrm{O}_{3}$ & 19.8 & 19.5 & 19.5 & 19.2 & 18.8 & 18.8 & 18.9 & 19.0 & 18.8 & 18.7 \\
\hline $\mathrm{MgO}$ & 14.4 & 14.7 & 14.7 & 14.9 & 15.0 & 14.7 & 15.0 & 15.0 & 14.8 & 14.8 \\
\hline $\mathrm{FeO}$ & 5.0 & 5.1 & 5.1 & 5.4 & 5.3 & 5.4 & 5.4 & 5.4 & 5.5 & 5.5 \\
\hline $\mathrm{CaO}$ & 11.1 & 11.0 & 10.9 & 10.5 & 10.5 & 10.7 & 10.4 & 10.5 & 10.5 & 10.4 \\
\hline $\mathrm{Na}_{2} \mathrm{O}$ & 3.2 & 3.1 & 3.1 & 3.1 & 3.0 & 3.0 & 3.0 & 3.0 & 3.0 & 3.0 \\
\hline $\mathrm{K}_{2} \mathrm{O}$ & 0.9 & 0.9 & 0.9 & 0.9 & 0.9 & 0.8 & 0.8 & 0.8 & 0.8 & 0.9 \\
\hline \multicolumn{11}{|l|}{ Std. Dev. } \\
\hline $\mathrm{SiO}_{2}$ & 7.3 & 7.4 & 7.4 & 7.5 & 7.7 & 7.7 & 7.5 & 7.6 & 7.5 & 7.5 \\
\hline $\mathrm{Al}_{2} \mathrm{O}_{3}$ & 6.3 & 6.5 & 6.5 & 6.6 & 6.7 & 6.7 & 6.6 & 6.7 & 6.7 & 6.7 \\
\hline $\mathrm{MgO}$ & 7.7 & 7.6 & 7.5 & 7.5 & 7.5 & 7.6 & 7.7 & 7.8 & 7.8 & 7.8 \\
\hline $\mathrm{FeO}$ & 3.7 & 3.8 & 3.7 & 3.9 & 3.9 & 3.9 & 3.8 & 3.8 & 3.9 & 3.9 \\
\hline $\mathrm{CaO}$ & 6.2 & 6.1 & 6.0 & 5.9 & 5.9 & 5.9 & 6.1 & 6.1 & 6.1 & 6.0 \\
\hline
\end{tabular}


Table A.2. (continued)

\begin{tabular}{lcccccccccc}
\hline Depth $(\mathrm{km})$ & 5 & 10 & 15 & 20 & 25 & 30 & 35 & 40 & 45 & 50 \\
\hline $\mathrm{T}\left({ }^{\circ} \mathrm{C}\right)$ & 62 & 101 & 136 & 168 & 198 & 227 & 256 & 284 & 312 & 340 \\
$\mathrm{P}(\mathrm{kbar})$ & 1.6 & 3.2 & 4.9 & 6.5 & 8.1 & 9.7 & 11.3 & 12.9 & 14.6 & 16.2 \\
\hline $\mathrm{Na} \mathrm{Na}_{2} \mathrm{O}$ & 1.7 & 1.7 & 1.7 & 1.7 & 1.7 & 1.7 & 1.7 & 1.7 & 1.7 & 1.7 \\
$\mathrm{~K}_{2} \mathrm{O}$ & 0.7 & 0.7 & 0.7 & 0.6 & 0.6 & 0.6 & 0.6 & 0.6 & 0.6 & 0.7 \\
$\mathrm{~N}$ & 222 & 235 & 240 & 249 & 263 & 273 & 290 & 284 & 305 & 320 \\
\hline
\end{tabular}

${ }^{\mathrm{a}} N$ denotes number of synthetic compositions in each $V_{p}$ bin.

Table A.3. Mean and Standard Deviation of Major Element Oxides as a Function of $V_{p}$ for a Warm Continental Geotherm $\left(q_{s}=90 \mathrm{~mW} \mathrm{~m}^{-2}\right)^{\mathrm{a}}$

\begin{tabular}{|c|c|c|c|c|c|c|c|c|c|c|}
\hline Depth (km) & 5 & 10 & 15 & 20 & 25 & 30 & 35 & 40 & 45 & 50 \\
\hline $\mathrm{T}\left({ }^{\circ} \mathrm{C}\right)$ & 136 & 238 & 327 & 410 & 488 & 564 & 638 & 711 & 784 & 856 \\
\hline P (kbar) & 1.6 & 3.2 & 4.9 & 6.5 & 8.1 & 9.7 & 11.3 & 12.9 & 14.6 & 16.2 \\
\hline \multicolumn{11}{|c|}{$V_{p}=6.2 \mathrm{~km} / \mathrm{s}$} \\
\hline \multicolumn{11}{|l|}{ Mean } \\
\hline $\mathrm{SiO}_{2}$ & 75.1 & 74.2 & 74.3 & 74.3 & 74.5 & 75.0 & 74.7 & 74.7 & 75.2 & 75.5 \\
\hline $\mathrm{Al}_{2} \mathrm{O}_{3}$ & 7.8 & 8.5 & 8.5 & 8.4 & 8.3 & 8.0 & 8.2 & 8.1 & 8.0 & 7.8 \\
\hline $\mathrm{MgO}$ & 2.3 & 2.4 & 2.4 & 2.4 & 2.4 & 2.4 & 2.2 & 2.2 & 2.2 & 2.1 \\
\hline $\mathrm{FeO}$ & 7.3 & 7.2 & 7.2 & 7.3 & 7.3 & 7.3 & 7.7 & 7.7 & 7.3 & 7.3 \\
\hline $\mathrm{CaO}$ & 2.2 & 2.2 & 2.2 & 2.2 & 2.2 & 2.1 & 2.0 & 2.0 & 1.9 & 2.0 \\
\hline $\mathrm{Na}_{2} \mathrm{O}$ & 2.4 & 2.6 & 2.6 & 2.5 & 2.5 & 2.4 & 2.4 & 2.4 & 2.5 & 2.4 \\
\hline $\mathrm{K}_{2} \mathrm{O}$ & 2.9 & 2.9 & 2.9 & 2.9 & 2.9 & 2.9 & 2.8 & 2.8 & 2.9 & 2.9 \\
\hline \multicolumn{11}{|l|}{ Std. Dev. } \\
\hline $\mathrm{SiO}_{2}$ & 6.5 & 7.5 & 7.5 & 7.5 & 7.6 & 7.7 & 7.8 & 7.8 & 7.7 & 7.8 \\
\hline $\mathrm{Al}_{2} \mathrm{O}_{3}$ & 5.3 & 6.2 & 6.2 & 6.2 & 6.2 & 6.2 & 6.3 & 6.3 & 6.3 & 6.4 \\
\hline $\mathrm{MgO}$ & 1.4 & 1.6 & 1.6 & 1.6 & 1.6 & 1.6 & 1.4 & 1.4 & 1.4 & 1.1 \\
\hline $\mathrm{FeO}$ & 5.9 & 5.8 & 5.7 & 5.8 & 5.8 & 5.7 & 5.7 & 5.7 & 5.5 & 5.5 \\
\hline $\mathrm{CaO}$ & 1.3 & 1.3 & 1.3 & 1.3 & 1.3 & 1.3 & 1.2 & 1.2 & 1.1 & 1.1 \\
\hline $\mathrm{Na}_{2} \mathrm{O}$ & 1.4 & 1.6 & 1.6 & 1.6 & 1.6 & 1.6 & 1.6 & 1.6 & 1.7 & 1.7 \\
\hline $\mathrm{K}_{2} \mathrm{O}$ & 1.4 & 1.4 & 1.4 & 1.4 & 1.4 & 1.4 & 1.3 & 1.3 & 1.3 & 1.3 \\
\hline$N$ & 171 & 181 & 183 & 186 & 189 & 190 & 179 & 177 & 164 & 156 \\
\hline \multicolumn{11}{|c|}{$V_{p}=6.3 \mathrm{~km} / \mathrm{s}$} \\
\hline Mean & & & & & & & & & & \\
\hline $\mathrm{SiO}_{2}$ & 71.9 & 71.4 & 71.1 & 71.4 & 71.5 & 71.7 & 71.7 & 71.8 & 71.8 & 71.8 \\
\hline $\mathrm{Al}_{2} \mathrm{O}_{3}$ & 9.9 & 10.3 & 10.5 & 10.3 & 10.2 & 10.1 & 10.1 & 10.0 & 10.0 & 10.1 \\
\hline $\mathrm{MgO}$ & 3.2 & 3.3 & 3.3 & 3.3 & 3.3 & 3.2 & 3.2 & 3.2 & 3.2 & 3.1 \\
\hline $\mathrm{FeO}$ & 7.0 & 6.9 & 6.9 & 6.8 & 6.7 & 6.7 & 6.7 & 6.8 & 6.8 & 6.8 \\
\hline $\mathrm{CaO}$ & 2.6 & 2.6 & 2.6 & 2.6 & 2.6 & 2.6 & 2.6 & 2.6 & 2.6 & 2.5 \\
\hline $\mathrm{Na}_{2} \mathrm{O}$ & 2.7 & 2.8 & 2.9 & 2.9 & 2.9 & 2.8 & 2.8 & 2.8 & 2.8 & 2.8 \\
\hline $\mathrm{K}_{2} \mathrm{O}$ & 2.7 & 2.8 & 2.7 & 2.8 & 2.8 & 2.9 & 2.9 & 2.8 & 2.8 & 2.9 \\
\hline \multicolumn{11}{|l|}{ Std. Dev. } \\
\hline $\mathrm{SiO}_{2}$ & 8.5 & 9.1 & 9.1 & 9.3 & 9.3 & 9.5 & 9.4 & 9.3 & 9.3 & 9.2 \\
\hline $\mathrm{Al}_{2} \mathrm{O}_{3}$ & 7.5 & 8.0 & 7.9 & 8.0 & 8.0 & 8.0 & 8.0 & 7.9 & 7.9 & 7.9 \\
\hline $\mathrm{MgO}$ & 2.1 & 2.1 & 2.0 & 2.0 & 2.0 & 2.0 & 2.0 & 2.0 & 2.0 & 2.0 \\
\hline $\mathrm{FeO}$ & 5.2 & 5.1 & 5.1 & 5.0 & 5.0 & 5.0 & 5.0 & 5.1 & 5.0 & 5.0 \\
\hline $\mathrm{CaO}$ & 1.6 & 1.6 & 1.6 & 1.6 & 1.6 & 1.6 & 1.6 & 1.6 & 1.6 & 1.5 \\
\hline $\mathrm{Na}_{2} \mathrm{O}$ & 1.9 & 2.1 & 2.1 & 2.0 & 2.0 & 2.1 & 2.0 & 2.0 & 2.0 & 2.0 \\
\hline $\mathrm{K}_{2} \mathrm{O}$ & 1.2 & 1.2 & 1.2 & 1.2 & 1.3 & 1.3 & 1.3 & 1.3 & 1.3 & 1.3 \\
\hline$N$ & 263 & 271 & 279 & 289 & 298 & 302 & 303 & 307 & 306 & 311 \\
\hline
\end{tabular}


Table A.3. (continued)

\begin{tabular}{|c|c|c|c|c|c|c|c|c|c|c|}
\hline Depth (km) & 5 & 10 & 15 & 20 & 25 & 30 & 35 & 40 & 45 & 50 \\
\hline $\mathrm{T}\left({ }^{\circ} \mathrm{C}\right)$ & 136 & 238 & 327 & 410 & 488 & 564 & 638 & 711 & 784 & 856 \\
\hline P (kbar) & 1.6 & 3.2 & 4.9 & 6.5 & 8.1 & 9.7 & 11.3 & 12.9 & 14.6 & 16.2 \\
\hline \multicolumn{11}{|c|}{$V_{p}=6.4 \mathrm{~km} / \mathrm{s}$} \\
\hline Mean & & & & & & & & & & \\
\hline $\mathrm{SiO}_{2}$ & 66.7 & 66.2 & 65.9 & 65.8 & 65.7 & 65.7 & 66.2 & 66.1 & 66.0 & 66.1 \\
\hline $\mathrm{Al}_{2} \mathrm{O}_{3}$ & 13.0 & 13.1 & 13.5 & 13.6 & 13.6 & 13.6 & 13.3 & 13.3 & 13.2 & 13.2 \\
\hline $\mathrm{MgO}$ & 4.3 & 4.3 & 4.3 & 4.4 & 4.4 & 4.4 & 4.4 & 4.4 & 4.3 & 4.3 \\
\hline $\mathrm{FeO}$ & 6.8 & 7.2 & 7.3 & 7.2 & 7.2 & 7.2 & 7.0 & 7.1 & 7.6 & 7.5 \\
\hline $\mathrm{CaO}$ & 3.2 & 3.2 & 3.2 & 3.1 & 3.1 & 3.1 & 3.1 & 3.1 & 3.1 & 3.0 \\
\hline $\mathrm{Na}_{2} \mathrm{O}$ & 3.4 & 3.4 & 3.4 & 3.5 & 3.5 & 3.5 & 3.4 & 3.4 & 3.4 & 3.4 \\
\hline $\mathrm{K}_{2} \mathrm{O}$ & 2.6 & 2.5 & 2.5 & 2.5 & 2.5 & 2.5 & 2.6 & 2.5 & 2.5 & 2.5 \\
\hline \multicolumn{11}{|l|}{ Std. Dev. } \\
\hline $\mathrm{SiO}_{2}$ & 9.3 & 9.7 & 9.9 & 10.0 & 10.0 & 9.9 & 10.1 & 10.2 & 10.6 & 10.5 \\
\hline $\mathrm{Al}_{2} \mathrm{O}_{3}$ & 8.7 & 8.7 & 8.9 & 8.9 & 8.8 & 8.8 & 8.8 & 8.8 & 8.9 & 8.8 \\
\hline $\mathrm{MgO}$ & 2.8 & 2.8 & 2.7 & 2.8 & 2.8 & 2.8 & 2.8 & 2.8 & 2.8 & 2.8 \\
\hline $\mathrm{FeO}$ & 5.0 & 5.4 & 5.4 & 5.4 & 5.3 & 5.3 & 5.3 & 5.4 & 5.6 & 5.6 \\
\hline $\mathrm{CaO}$ & 2.1 & 2.0 & 2.0 & 2.0 & 2.0 & 2.0 & 2.0 & 2.0 & 2.0 & 2.0 \\
\hline $\mathrm{Na}_{2} \mathrm{O}$ & 2.2 & 2.2 & 2.2 & 2.2 & 2.2 & 2.2 & 2.2 & 2.2 & 2.2 & 2.2 \\
\hline $\mathrm{K}_{2} \mathrm{O}$ & 1.1 & 1.1 & 1.1 & 1.1 & 1.1 & 1.1 & 1.1 & 1.1 & 1.2 & 1.2 \\
\hline$N$ & 309 & 317 & 330 & 328 & 332 & 335 & 346 & 347 & 358 & 364 \\
\hline \multicolumn{11}{|c|}{$V_{p}=6.5 \mathrm{~km} / \mathrm{s}$} \\
\hline Mean & & & & & & & & & & \\
\hline $\mathrm{SiO}_{2}$ & 60.3 & 60.6 & 60.1 & 60.2 & 59.9 & 59.8 & 59.7 & 59.7 & 59.8 & 59.7 \\
\hline $\mathrm{Al}_{2} \mathrm{O}_{3}$ & 16.9 & 16.6 & 16.8 & 16.7 & 16.9 & 16.9 & 17.0 & 16.8 & 16.8 & 16.8 \\
\hline $\mathrm{MgO}$ & 4.8 & 5.0 & 5.1 & 5.1 & 5.1 & 5.1 & 5.1 & 5.2 & 5.1 & 5.1 \\
\hline $\mathrm{FeO}$ & 7.7 & 7.7 & 7.8 & 7.8 & 7.9 & 8.1 & 8.2 & 8.2 & 8.2 & 8.3 \\
\hline $\mathrm{CaO}$ & 4.2 & 4.2 & 4.2 & 4.2 & 4.2 & 4.1 & 4.1 & 4.0 & 4.0 & 4.0 \\
\hline $\mathrm{Na}_{2} \mathrm{O}$ & 4.0 & 3.9 & 4.0 & 4.0 & 4.0 & 4.0 & 4.0 & 4.0 & 4.0 & 4.0 \\
\hline $\mathrm{K}_{2} \mathrm{O}$ & 2.1 & 2.1 & 2.1 & 2.1 & 2.0 & 2.0 & 2.1 & 2.1 & 2.1 & 2.0 \\
\hline \multicolumn{11}{|l|}{ Std. Dev. } \\
\hline $\mathrm{SiO}_{2}$ & 9.6 & 9.4 & 9.7 & 9.6 & 9.8 & 10.0 & 10.1 & 10.0 & 10.1 & 10.3 \\
\hline $\mathrm{Al}_{2} \mathrm{O}_{3}$ & 8.3 & 8.2 & 8.3 & 8.3 & 8.4 & 8.4 & 8.5 & 8.4 & 8.4 & 8.4 \\
\hline $\mathrm{MgO}$ & 3.1 & 3.3 & 3.3 & 3.3 & 3.3 & 3.3 & 3.3 & 3.3 & 3.3 & 3.3 \\
\hline $\mathrm{FeO}$ & 5.7 & 5.7 & 5.7 & 5.7 & 5.7 & 5.8 & 5.7 & 5.8 & 5.8 & 5.9 \\
\hline $\mathrm{CaO}$ & 2.8 & 2.8 & 2.8 & 2.8 & 2.8 & 2.7 & 2.7 & 2.7 & 2.7 & 2.7 \\
\hline $\mathrm{Na}_{2} \mathrm{O}$ & 2.2 & 2.1 & 2.2 & 2.2 & 2.2 & 2.2 & 2.2 & 2.2 & 2.2 & 2.2 \\
\hline $\mathrm{K}_{2} \mathrm{O}$ & 1.1 & 1.1 & 1.1 & 1.1 & 1.1 & 1.1 & 1.1 & 1.1 & 1.1 & 1.1 \\
\hline$N$ & 406 & 417 & 429 & 432 & 442 & 452 & 446 & 440 & 440 & 446 \\
\hline \multicolumn{11}{|c|}{$V_{p}=6.6 \mathrm{~km} / \mathrm{s}$} \\
\hline Mean & & & & & & & & & & \\
\hline $\mathrm{SiO}_{2}$ & 57.9 & 57.4 & 57.2 & 57.1 & 57.1 & 57.3 & 57.3 & 57.2 & 57.4 & 57.4 \\
\hline $\mathrm{Al}_{2} \mathrm{O}_{3}$ & 17.8 & 18.1 & 18.0 & 18.0 & 17.9 & 17.7 & 17.6 & 17.6 & 17.5 & 17.5 \\
\hline $\mathrm{MgO}$ & 5.4 & 5.5 & 5.6 & 5.6 & 5.7 & 5.8 & 5.9 & 6.0 & 6.0 & 6.0 \\
\hline $\mathrm{FeO}$ & 8.2 & 8.3 & 8.5 & 8.5 & 8.6 & 8.6 & 8.6 & 8.6 & 8.5 & 8.6 \\
\hline $\mathrm{CaO}$ & 4.9 & 4.9 & 5.0 & 4.9 & 5.0 & 4.9 & 4.9 & 4.8 & 4.8 & 4.8 \\
\hline $\mathrm{Na}_{2} \mathrm{O}$ & 4.0 & 4.1 & 4.0 & 4.1 & 4.0 & 4.0 & 4.0 & 4.0 & 4.0 & 4.0 \\
\hline $\mathrm{K}_{2} \mathrm{O}$ & 1.8 & 1.7 & 1.7 & 1.7 & 1.7 & 1.7 & 1.7 & 1.7 & 1.7 & 1.7 \\
\hline \multicolumn{11}{|l|}{ Std. Dev. } \\
\hline $\mathrm{SiO}_{2}$ & 9.8 & 9.9 & 10.0 & 10.1 & 10.1 & 10.2 & 10.2 & 10.2 & 10.0 & 10.1 \\
\hline $\mathrm{Al}_{2} \mathrm{O}_{3}$ & 8.2 & 8.2 & 8.2 & 8.3 & 8.3 & 8.4 & 8.4 & 8.4 & 8.3 & 8.3 \\
\hline $\mathrm{MgO}$ & 3.4 & 3.4 & 3.4 & 3.4 & 3.4 & 3.5 & 3.5 & 3.6 & 3.6 & 3.6 \\
\hline $\mathrm{FeO}$ & 5.6 & 5.6 & 5.6 & 5.6 & 5.6 & 5.7 & 5.7 & 5.7 & 5.7 & 5.7 \\
\hline $\mathrm{CaO}$ & 3.0 & 3.0 & 3.0 & 3.0 & 3.1 & 3.0 & 3.0 & 3.0 & 3.0 & 3.0 \\
\hline
\end{tabular}


Table A.3. (continued)

\begin{tabular}{|c|c|c|c|c|c|c|c|c|c|c|}
\hline Depth $(\mathrm{km})$ & 5 & 10 & 15 & 20 & 25 & 30 & 35 & 40 & 45 & 50 \\
\hline $\mathrm{T}\left({ }^{\circ} \mathrm{C}\right)$ & 136 & 238 & 327 & 410 & 488 & 564 & 638 & 711 & 784 & 856 \\
\hline P (kbar) & 1.6 & 3.2 & 4.9 & 6.5 & 8.1 & 9.7 & 11.3 & 12.9 & 14.6 & 16.2 \\
\hline $\mathrm{Na}_{2} \mathrm{O}$ & 2.2 & 2.3 & 2.3 & 2.3 & 2.3 & 2.3 & 2.3 & 2.3 & 2.3 & 2.3 \\
\hline $\mathrm{K}_{2} \mathrm{O}$ & 1.1 & 1.1 & 1.1 & 1.1 & 1.0 & 1.0 & 1.0 & 1.0 & 1.0 & 1.0 \\
\hline$N$ & 514 & 539 & 549 & 559 & 575 & 586 & 586 & 594 & 603 & 608 \\
\hline \multicolumn{11}{|c|}{$V_{p}=6.7 \mathrm{~km} / \mathrm{s}$} \\
\hline $\begin{array}{l}\text { Mean } \\
\mathrm{SiO}_{2}\end{array}$ & 56.6 & 56.2 & 56.1 & 56.0 & 56.0 & 56.1 & 56.2 & 56.2 & 56.2 & 56.3 \\
\hline $\mathrm{Al}_{2} \mathrm{O}_{3}$ & 17.5 & 17.7 & 17.6 & 17.7 & 17.6 & 17.6 & 17.5 & 17.5 & 17.5 & 17.4 \\
\hline $\mathrm{MgO}$ & 6.9 & 7.1 & 7.2 & 7.3 & 7.4 & 7.4 & 7.5 & 7.4 & 7.5 & 7.6 \\
\hline $\mathrm{FeO}$ & 8.2 & 8.3 & 8.3 & 8.3 & 8.2 & 8.2 & 8.2 & 8.2 & 8.2 & 8.1 \\
\hline $\mathrm{CaO}$ & 5.4 & 5.4 & 5.4 & 5.4 & 5.4 & 5.5 & 5.4 & 5.4 & 5.4 & 5.4 \\
\hline $\mathrm{Na}_{2} \mathrm{O}$ & 3.8 & 3.8 & 3.8 & 3.8 & 3.8 & 3.7 & 3.7 & 3.7 & 3.7 & 3.7 \\
\hline $\mathrm{K}_{2} \mathrm{O}$ & 1.5 & 1.5 & 1.5 & 1.5 & 1.5 & 1.5 & 1.5 & 1.5 & 1.5 & 1.5 \\
\hline \multicolumn{11}{|l|}{ Std. Dev. } \\
\hline $\mathrm{SiO}_{2}$ & 9.9 & 10.1 & 10.0 & 10.1 & 10.1 & 10.0 & 10.0 & 10.0 & 10.0 & 9.9 \\
\hline $\mathrm{Al}_{2} \mathrm{O}_{3}$ & 8.4 & 8.5 & 8.4 & 8.5 & 8.4 & 8.4 & 8.3 & 8.4 & 8.4 & 8.4 \\
\hline $\mathrm{MgO}$ & 3.6 & 3.7 & 3.7 & 3.7 & 3.7 & 3.7 & 3.7 & 3.9 & 3.9 & 4.0 \\
\hline $\mathrm{FeO}$ & 5.3 & 5.4 & 5.5 & 5.4 & 5.4 & 5.3 & 5.3 & 5.3 & 5.3 & 5.2 \\
\hline $\mathrm{CaO}$ & 3.4 & 3.4 & 3.4 & 3.4 & 3.4 & 3.4 & 3.4 & 3.4 & 3.4 & 3.4 \\
\hline $\mathrm{Na}_{2} \mathrm{O}$ & 2.3 & 2.4 & 2.4 & 2.4 & 2.4 & 2.4 & 2.3 & 2.4 & 2.4 & 2.3 \\
\hline $\mathrm{K}_{2} \mathrm{O}$ & 1.0 & 1.0 & 1.0 & 1.0 & 1.0 & 1.0 & 1.0 & 1.0 & 1.0 & 1.0 \\
\hline$N$ & 603 & 642 & 651 & 665 & 656 & 659 & 669 & 677 & 682 & 684 \\
\hline \multicolumn{11}{|c|}{$V_{p}=6.8 \mathrm{~km} / \mathrm{s}$} \\
\hline $\begin{array}{l}\text { Mean } \\
\mathrm{SiO}_{2}\end{array}$ & 55.0 & 55.4 & 55.3 & 55.4 & 55.5 & 55.3 & 55.3 & 55.3 & 55.2 & 55.4 \\
\hline $\mathrm{Al}_{2} \mathrm{O}_{3}$ & 17.9 & 17.5 & 17.4 & 17.3 & 17.2 & 17.3 & 17.3 & 17.3 & 17.3 & 17.1 \\
\hline $\mathrm{MgO}$ & 8.2 & 8.6 & 8.9 & 8.9 & 9.1 & 9.0 & 9.1 & 9.0 & 9.1 & 9.2 \\
\hline $\mathrm{FeO}$ & 7.7 & 7.2 & 7.2 & 7.1 & 7.1 & 7.2 & 7.2 & 7.2 & 7.2 & 7.1 \\
\hline $\mathrm{CaO}$ & 6.0 & 6.2 & 6.2 & 6.2 & 6.2 & 6.2 & 6.1 & 6.2 & 6.2 & 6.3 \\
\hline $\mathrm{Na}_{2} \mathrm{O}$ & 3.7 & 3.6 & 3.6 & 3.5 & 3.5 & 3.5 & 3.5 & 3.5 & 3.5 & 3.5 \\
\hline $\mathrm{K}_{2} \mathrm{O}$ & 1.5 & 1.5 & 1.5 & 1.5 & 1.5 & 1.5 & 1.5 & 1.5 & 1.5 & 1.5 \\
\hline \multicolumn{11}{|l|}{ Std. Dev. } \\
\hline $\mathrm{SiO}_{2}$ & 9.6 & 9.5 & 9.4 & 9.3 & 9.2 & 9.1 & 9.1 & 9.0 & 9.0 & 8.9 \\
\hline $\mathrm{Al}_{2} \mathrm{O}_{3}$ & 8.3 & 8.3 & 8.2 & 8.1 & 8.2 & 8.1 & 8.0 & 8.1 & 8.0 & 8.1 \\
\hline $\mathrm{MgO}$ & 4.3 & 4.5 & 4.6 & 4.7 & 4.7 & 4.7 & 4.8 & 4.8 & 4.8 & 4.8 \\
\hline $\mathrm{FeO}$ & 5.2 & 5.0 & 5.0 & 4.9 & 4.9 & 4.9 & 4.9 & 4.8 & 4.8 & 4.7 \\
\hline $\mathrm{CaO}$ & 4.0 & 3.9 & 4.0 & 3.9 & 3.9 & 3.9 & 3.9 & 3.9 & 3.9 & 3.9 \\
\hline $\mathrm{Na}_{2} \mathrm{O}$ & 2.3 & 2.3 & 2.2 & 2.2 & 2.2 & 2.2 & 2.2 & 2.2 & 2.2 & 2.2 \\
\hline $\mathrm{K}_{2} \mathrm{O}$ & 0.9 & 0.9 & 0.9 & 0.9 & 0.9 & 0.9 & 0.9 & 0.9 & 0.9 & 0.9 \\
\hline$N$ & 690 & 685 & 704 & 709 & 706 & 700 & 709 & 711 & 711 & 723 \\
\hline \multicolumn{11}{|c|}{$V_{p}=6.9 \mathrm{~km} / \mathrm{s}$} \\
\hline $\begin{array}{l}\text { Mean } \\
\mathrm{SiO}_{2}\end{array}$ & 53.6 & 53.7 & 53.9 & 53.9 & 53.9 & 53.8 & 53.7 & 53.7 & 53.7 & 53.7 \\
\hline $\mathrm{Al}_{2} \mathrm{O}_{3}$ & 17.9 & 17.8 & 17.5 & 17.4 & 17.4 & $\begin{array}{l}5.0 \\
17.4\end{array}$ & 17.5 & $\begin{array}{l}53 . / \\
17.5\end{array}$ & $\begin{array}{l}53.1 \\
17.5\end{array}$ & $\begin{array}{l}55.1 \\
17.3\end{array}$ \\
\hline $\mathrm{MgO}$ & 9.7 & 9.8 & 9.9 & 10.1 & 10.2 & 10.2 & 10.2 & 10.2 & 10.2 & 10.3 \\
\hline $\mathrm{FeO}$ & 7.1 & 6.9 & 6.7 & 6.8 & 6.8 & 6.8 & 6.8 & 6.8 & 6.9 & 6.9 \\
\hline $\mathrm{CaO}$ & 6.6 & 6.8 & 7.0 & 7.0 & 7.0 & 7.0 & 7.0 & 7.0 & 7.0 & 7.0 \\
\hline $\mathrm{Na}_{2} \mathrm{O}$ & 3.6 & 3.5 & 3.4 & 3.4 & 3.4 & 3.4 & 3.4 & 3.4 & 3.4 & 3.4 \\
\hline $\mathrm{K}_{2} \mathrm{O}$ & 1.4 & 1.4 & 1.4 & 1.4 & 1.4 & 1.4 & 1.4 & 1.4 & 1.4 & 1.4 \\
\hline
\end{tabular}


Table A.3. (continued)

\begin{tabular}{|c|c|c|c|c|c|c|c|c|c|c|}
\hline Depth (km) & 5 & 10 & 15 & 20 & 25 & 30 & 35 & 40 & 45 & 50 \\
\hline $\mathrm{T}\left({ }^{\circ} \mathrm{C}\right)$ & 136 & 238 & 327 & 410 & 488 & 564 & 638 & 711 & 784 & \\
\hline P (kbar) & 1.6 & 3.2 & 4.9 & 6.5 & 8.1 & 9.7 & 11.3 & 12.9 & 14.6 & 16.2 \\
\hline \multicolumn{11}{|l|}{ Std. Dev. } \\
\hline $\mathrm{SiO}_{2}$ & 9.1 & 9.0 & 8.9 & 8.8 & 8.7 & 8.8 & 8.8 & 8.8 & 8.8 & 8.8 \\
\hline $\mathrm{Al}_{2} \mathrm{O}_{3}$ & 8.1 & 8.1 & 8.0 & 8.0 & 7.9 & 7.9 & 7.9 & 8.0 & 7.9 & 8.0 \\
\hline $\mathrm{MgO}$ & 5.2 & 5.4 & 5.4 & 5.5 & 5.6 & 5.6 & 5.6 & 5.5 & 5.6 & 5.6 \\
\hline $\mathrm{FeO}$ & 4.8 & 4.6 & 4.5 & 4.6 & 4.6 & 4.6 & 4.7 & 4.7 & 4.7 & 4.7 \\
\hline $\mathrm{CaO}$ & 4.3 & 4.3 & 4.5 & 4.5 & 4.5 & 4.5 & 4.5 & 4.4 & 4.4 & 4.4 \\
\hline $\mathrm{Na}_{2} \mathrm{O}$ & 2.2 & 2.1 & 2.1 & 2.1 & 2.1 & 2.1 & 2.1 & 2.1 & 2.1 & 2.1 \\
\hline $\mathrm{K}_{2} \mathrm{O}$ & 0.9 & 0.9 & 0.9 & 0.9 & 0.9 & 0.9 & 0.9 & 0.8 & 0.8 & 0.8 \\
\hline$N$ & 678 & 645 & 650 & 651 & 669 & 669 & 675 & 683 & 689 & 695 \\
\hline \multicolumn{11}{|c|}{$V_{p}=7.0 \mathrm{~km} / \mathrm{s}$} \\
\hline \multicolumn{11}{|l|}{ Mean } \\
\hline $\mathrm{SiO}_{2}$ & 52.6 & 52.3 & 52.4 & 52.2 & 51.7 & 51.7 & 51.5 & 51.3 & 51.3 & 51 \\
\hline $\mathrm{Al}_{2} \mathrm{O}_{3}$ & 17.6 & 17.7 & 17.5 & 17.6 & 17.9 & 17.8 & 18.0 & 18.1 & 17.9 & 17 \\
\hline $\mathrm{MgO}$ & 11.1 & 11.2 & 11.3 & 11.4 & 11.5 & 11.7 & 11.7 & 11.8 & 12.1 & 12.1 \\
\hline $\mathrm{FeO}$ & 7.1 & 7.2 & 7.2 & 7.3 & 7.3 & 7.1 & 7.1 & 7.2 & 7.1 & 7.2 \\
\hline $\mathrm{CaO}$ & 7.1 & 7.1 & 7.1 & 7.1 & 7.2 & 7.2 & 7.2 & 7.1 & 7.1 & 7.1 \\
\hline $\mathrm{Na}_{2} \mathrm{O}$ & 3.4 & 3.4 & 3.3 & 3.3 & 3.4 & 3.4 & 3.4 & 3.4 & 3.4 & 3.4 \\
\hline $\mathrm{K}_{2} \mathrm{O}$ & 1.2 & 1.2 & 1.1 & 1.1 & 1.1 & 1.1 & 1.1 & 1.1 & 1.1 & 1.1 \\
\hline
\end{tabular}

Std. Dev.

$\mathrm{SiO}_{2}$

$\mathrm{Al}_{2} \mathrm{O}_{3}$

$\mathrm{MgO}$

$\mathrm{FeO}$

$\mathrm{CaO}$

$\mathrm{Na}_{2} \mathrm{O}$

$\mathrm{K}_{2} \mathrm{O}$

$N$

$596 \quad 587$

8.8
7.8

8.8

$8.7 \quad 8.8$

8.8
7.8

$8.7 \quad 8.9$

8.9
7.9

$8.9 \quad 9.0$

$9.0 \quad 8.9$

$5.4 \quad 5.4$

5.5

5.6

5.7

$4.8 \quad 4.9$

4.8
4.7

4.8

4.7

5.8

5.9

7.9

8.0

5.9

5.0

5.0

5.0

5.9
4.9

\section{7}

4.7

4.8

4.8

4.7

2.1
0.8

2.1
0.8

2.1
0.8

2.1

2.1

2.1

$\frac{5}{86}$

6.2

$N$

573

$579 \quad 585$

613

616

618

641

640

Mean

$\mathrm{SiO}_{2}$

$\mathrm{Al}_{2} \mathrm{O}_{3}$

$\mathrm{MgO}$

$\mathrm{FeO}$

$\mathrm{CaO}$

$\mathrm{Na}_{2} \mathrm{O}$

$\mathrm{K}_{2} \mathrm{O}$

51.4

51.2

$V_{p}=7.1 \mathrm{~km} / \mathrm{s}$

Std. Dev.

$\mathrm{SiO}_{2}$

$\mathrm{Al}_{2} \mathrm{O}_{3}$

$\mathrm{MgO}$

$\mathrm{FeO}$

$\mathrm{CaO}$

$\mathrm{Na}_{2} \mathrm{O}$

$\mathrm{K}_{2} \mathrm{O}$

17.4

12.4

17.4

12.5

50.6

$50.5 \quad 50.5$

17.7

$\begin{array}{ll}50.5 & 50.5 \\ 17.9 & 17.9\end{array}$

12.7

12.6

12.6

7.3

7.2

7.2

$\begin{array}{ll}7.1 & 7.2 \\ 7.5 & 7.5\end{array}$

7.4

7.5

7.6

$\begin{array}{ll}3.3 & 3.3 \\ 1.0 & 1.0\end{array}$

50.5

$\begin{array}{ll}17.9 & 17.9 \\ 12.6 & 12.6\end{array}$

50.3

$50.3 \quad 50.1$

3.3
1.0

7.1

7.0

18.1

12.6

$\begin{array}{ll}7.6 & 7.7\end{array}$

$\begin{array}{ll}3.3 & 3.3 \\ 1.0 & 1.0\end{array}$

7.1
7.7

12.5

$\begin{array}{ll}7.0 & 7.0\end{array}$

$\begin{array}{ll}3.1 & 1.0\end{array}$

$1.0 \quad 1.0$

$\begin{array}{ll}3.0 & 1.0\end{array}$

3.3

3.3

$\begin{array}{lll}7.7 & 7.8 & 3.3 \\ 1.0 & 1.0 & 1.0\end{array}$

N

$\begin{array}{lll}8.6 & 8.3 & 8.3 \\ 7.5 & 7.5 & 7.6 \\ 5.9 & 6.0 & 6.0 \\ 5.0 & 5.0 & 5.0 \\ 5.1 & 5.1 & 5.1 \\ 2.0 & 2.0 & 2.0 \\ 0.8 & 0.8 & 0.7 \\ 551 & 567 & 552\end{array}$

$\begin{array}{ll}8.4 & 8.4 \\ 7.6 & 7.6 \\ 6.1 & 6.1 \\ 4.9 & 5.0 \\ 5.2 & 5.1 \\ 2.0 & 2.0 \\ 0.7 & 0.8 \\ 544 & 532\end{array}$

\section{4}

$\begin{array}{llll}8.4 & 8.4 & 8.5 & 8.5 \\ 7.6 & 7.7 & 7.7 & 7.7 \\ 6.1 & 6.3 & 6.3 & 6.3 \\ 4.8 & 4.8 & 4.8 & 4.7 \\ 5.1 & 5.1 & 5.1 & 5.1 \\ 2.0 & 2.0 & 2.0 & 2.0 \\ 0.7 & 0.7 & 0.7 & 0.7 \\ 540 & 549 & 541 & 551\end{array}$

Mean

$\mathrm{SiO}_{2}$

$\mathrm{Al}_{2} \mathrm{O}_{3}$

$\mathrm{MgO}$

49.7

49.6

$\begin{array}{lll}49.3 & 49.1 & 49.0\end{array}$

$\begin{array}{lll}18.1 & 18.1 & 18.2\end{array}$

18.5

49.0
18.7

48.8

49.0

49.0

$48.7 \quad 48.6$

$12.8 \quad 13.0$

$12.9 \quad 12.9$

12.5

18.7
12.4

18.9

19.3

19.3 
Table A.3. (continued)

\begin{tabular}{lcccccccccc}
\hline Depth $(\mathrm{km})$ & 5 & 10 & 15 & 20 & 25 & 30 & 35 & 40 & 45 & 50 \\
\hline $\mathrm{T}\left({ }^{\circ} \mathrm{C}\right)$ & 136 & 238 & 327 & 410 & 488 & 564 & 638 & 711 & 784 & 856 \\
$\mathrm{P}(\mathrm{kbar})$ & 1.6 & 3.2 & 4.9 & 6.5 & 8.1 & 9.7 & 11.3 & 12.9 & 14.6 & 16.2 \\
\hline $\mathrm{FeO}$ & 7.1 & 7.0 & 6.9 & 6.8 & 6.7 & 6.8 & 6.6 & 6.5 & 6.4 & 6.4 \\
$\mathrm{CaO}$ & 8.0 & 8.3 & 8.4 & 8.6 & 8.7 & 8.9 & 9.1 & 9.3 & 9.5 & 9.5 \\
$\mathrm{Na} 2$ & 3.3 & 3.2 & 3.2 & 3.3 & 3.3 & 3.3 & 3.2 & 3.2 & 3.3 & 3.2 \\
$\mathrm{~K}_{2} \mathrm{O}$ & 1.0 & 1.0 & 0.9 & 0.9 & 0.9 & 0.9 & 0.9 & 0.9 & 0.9 & 0.9
\end{tabular}

Std. Dev.

$\mathrm{SiO}_{2}$

$\mathrm{Al}_{2} \mathrm{O}_{3}$

$\mathrm{MgO}$

$\mathrm{FeO}$

$\mathrm{CaO}$

$\mathrm{Na}_{2} \mathrm{O}$

$\mathrm{K}_{2} \mathrm{O}$

N

Mean

$\mathrm{SiO}_{2}$

$\mathrm{Al}_{2} \mathrm{O}_{3}$

$\mathrm{MgO}$

$\mathrm{FeO}$

$\mathrm{CaO}$

$\mathrm{Na}_{2} \mathrm{O}$

$\mathrm{K}_{2} \mathrm{O}$

Std. Dev.

$\mathrm{SiO}_{2}$

$\mathrm{Al}_{2} \mathrm{O}_{3}$

$\mathrm{MgO}$

$\mathrm{FeO}$

$\mathrm{CaO}$

$\mathrm{Na}_{2} \mathrm{O}$

$\mathrm{K}_{2} \mathrm{O}$

N

Mean

$\mathrm{SiO}_{2}$

$\mathrm{Al}_{2} \mathrm{O}_{3}$

$\mathrm{MgO}$

$\mathrm{FeO}$

$\mathrm{CaO}$

$\mathrm{Na}_{2} \mathrm{O}$

$\mathrm{K}_{2} \mathrm{O}$

Std. Dev.

$\mathrm{SiO}_{2}$

$\mathrm{Al}_{2} \mathrm{O}_{3}$

$\mathrm{MgO}$

$\mathrm{FeO}$

$\mathrm{CaO}$

$\mathrm{Na}_{2} \mathrm{O}$

$\mathrm{K}_{2} \mathrm{O}$

N

$\begin{array}{ll}8.5 & 8.3 \\ 7.8 & 7.8 \\ 6.6 & 6.7 \\ 4.8 & 4.8 \\ 5.4 & 5.5 \\ 2.0 & 2.0 \\ 0.7 & 0.7 \\ 469 & 478\end{array}$

$8.3 \quad 8.1$

$8.1 \quad 8.3$

$8.3 \quad 8.2$

$8.2 \quad 8.2$

\section{2}

7.8
6.8

8.1

7.7

6.8

4.4

4.3

5.6

2.0

5.5

5.5

$5.6 \quad 5.5$

$\begin{array}{ll}5.6 & 2.0\end{array}$

$\begin{array}{ll}0.7 & 0.7\end{array}$

0.7

1.9
0.7

0.7

$475 \quad 465$

438

439

$$
V_{p}=7.3 \mathrm{~km} / \mathrm{s}
$$

$\begin{array}{cccccccccc}47.8 & 47.2 & 47.5 & 47.7 & 47.7 & 47.8 & 47.6 & 47.7 & 47.6 & 47.7 \\ 19.4 & 20.0 & 19.5 & 19.2 & 19.3 & 19.1 & 19.2 & 19.2 & 19.2 & 19.3 \\ 13.0 & 13.0 & 13.0 & 13.2 & 13.2 & 13.3 & 13.6 & 13.3 & 13.4 & 13.3 \\ 6.6 & 6.3 & 6.3 & 6.4 & 6.2 & 6.1 & 6.1 & 6.0 & 6.0 & 5.8 \\ 9.0 & 9.3 & 9.5 & 9.5 & 9.5 & 9.6 & 9.6 & 9.9 & 9.8 & 9.9 \\ 3.4 & 3.4 & 3.3 & 3.2 & 3.2 & 3.2 & 3.2 & 3.1 & 3.2 & 3.2 \\ 0.9 & 0.9 & 0.9 & 0.8 & 0.8 & 0.8 & 0.8 & 0.8 & 0.8 & 0.8\end{array}$

\section{8}

$\begin{array}{ll}7.9 & 7.8 \\ 7.7 & 7.5 \\ 7.0 & 7.3 \\ 4.2 & 4 . \\ 5.5 & 5.7 \\ 1.9 & 1.9 \\ 0.7 & 0.7\end{array}$

383

355

7.7
7.6
7.2
4.1
5.7
1.9
0.7

$\begin{array}{ll}7.7 & 7.6 \\ 7.6 & 7.6 \\ 7.2 & 7.2 \\ 4.2 & 4.1 \\ 5.6 & 5.7 \\ 1.9 & 1.9 \\ 0.7 & 0.7\end{array}$

$7.6 \quad 7.5$

7.5

7.5
7.5

$\begin{array}{lll}7.5 & 7.4 & 7.3 \\ 7.4 & 7.3 & 7.1 \\ 7.4 & 7.4 & 7.4 \\ 4.1 & 4.0 & 4.1 \\ 5.7 & 5.7 & 5.8 \\ 1.9 & 1.8 & 1.8 \\ 0.7 & 0.7 & 0.7\end{array}$

$\begin{array}{ll}1.9 & 1.9 \\ 0.7 & 0.7\end{array}$

7.2

7.6

7.3

4.1
5.7

5.7
1.9

1.9
0.7

360

$363 \quad 371$

367

7.4

4.1

5.7

1.9
0.7

0.7

368

365

369

355

$$
V_{p}=7.4 \mathrm{~km} / \mathrm{s}
$$

$\begin{array}{ccccc}47.8 & 47.5 & 47.3 & 47.4 & 47.6 \\ 18.7 & 18.9 & 19.3 & 19.0 & 18.8 \\ 13.7 & 13.7 & 13.5 & 13.8 & 13.8 \\ 5.9 & 6.0 & 6.0 & 6.0 & 5.9 \\ 9.9 & 9.8 & 10.0 & 10.0 & 10.1 \\ 3.0 & 3.1 & 3.1 & 3.1 & 3.0 \\ 0.8 & 0.8 & 0.8 & 0.8 & 0.8\end{array}$

$\begin{array}{ccccc}47.2 & 47.1 & 47.2 & 47.2 & 46.9 \\ 18.8 & 18.8 & 18.7 & 18.7 & 19.0 \\ 14.3 & 14.4 & 14.4 & 14.5 & 14.5 \\ 5.9 & 5.9 & 5.8 & 5.7 & 5.5 \\ 9.9 & 10.0 & 10.1 & 10.1 & 10.3 \\ 3.0 & 3.0 & 3.0 & 3.0 & 3.0 \\ 0.8 & 0.8 & 0.8 & 0.8 & 0.8\end{array}$

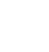

$\begin{array}{llll}7.3 & 7.4 & 7.6 & 7.3 \\ 7.2 & 7.1 & 7.0 & 6.8 \\ 7.4 & 7.4 & 7.4 & 7.6 \\ 4.0 & 4.2 & 4.2 & 4.2 \\ 5.9 & 6.0 & 6.1 & 6.0 \\ 1.9 & 1.9 & 1.9 & 1.8 \\ 0.7 & 0.7 & 0.7 & 0.6 \\ 333 & 308 & 290 & 284\end{array}$

7.2
6.7
7.8
4.1
6.2
1.8
0.6

0.8

7.2
6.5
7.9
4.0
6.1
1.8
0.6

291

7.2

6.6
7.9

7.9
4.0

4.0
6.2

6.2
1.8

0.6

7.1
6.5
8.0
4.0
6.2
1.8
0.6

7.1

7.0

$\begin{array}{ll}7.9 & 6.1 \\ 3.9 & 7.9\end{array}$

$\begin{array}{ll}3.9 & 3.8\end{array}$

$\begin{array}{ll}3.9 & 3.8 \\ 6.2 & 6.3\end{array}$

$\begin{array}{ll}6.2 & 6.3 \\ 1.8 & 1.7\end{array}$

291

288

$\begin{array}{ll}0.7 & 0.7\end{array}$

282

291

291

286

272 
Table A.3. (continued)

\begin{tabular}{|c|c|c|c|c|c|c|c|c|c|c|}
\hline Depth $(\mathrm{km})$ & 5 & 10 & 15 & 20 & 25 & 30 & 35 & 40 & 45 & 50 \\
\hline $\mathrm{T}\left({ }^{\circ} \mathrm{C}\right)$ & 136 & 238 & 327 & 410 & 488 & 564 & 638 & 711 & 784 & 856 \\
\hline P (kbar) & 1.6 & 3.2 & 4.9 & 6.5 & 8.1 & 9.7 & 11.3 & 12.9 & 14.6 & 16.2 \\
\hline \multicolumn{11}{|c|}{$V_{p}=7.5 \mathrm{~km} / \mathrm{s}$} \\
\hline Mean & & & & & & & & & & \\
\hline $\mathrm{SiO}_{2}$ & 47.4 & 47.4 & 46.6 & 46.0 & 45.5 & 45.0 & 44.9 & 44.9 & 45.0 & 44.8 \\
\hline $\mathrm{Al}_{2} \mathrm{O}_{3}$ & 18.4 & 18.4 & 19.2 & 19.5 & 19.7 & 20.0 & 20.3 & 20.2 & 20.0 & 20.3 \\
\hline $\mathrm{MgO}$ & 14.7 & 14.4 & 14.4 & 14.5 & 14.6 & 14.6 & 14.2 & 14.5 & 14.4 & 14.3 \\
\hline $\mathrm{FeO}$ & 5.8 & 5.7 & 5.5 & 5.2 & 5.2 & 5.2 & 5.1 & 5.0 & 5.0 & 5.0 \\
\hline $\mathrm{CaO}$ & 10.1 & 10.3 & 10.5 & 10.9 & 10.9 & 11.1 & 11.5 & 11.5 & 11.6 & 11.7 \\
\hline $\mathrm{Na}_{2} \mathrm{O}$ & 2.9 & 2.9 & 3.0 & 3.1 & 3.1 & 3.2 & 3.2 & 3.2 & 3.1 & 3.2 \\
\hline $\mathrm{K}_{2} \mathrm{O}$ & 0.8 & 0.8 & 0.8 & 0.9 & 0.9 & 0.9 & 0.9 & 0.9 & 0.9 & 0.9 \\
\hline \multicolumn{11}{|l|}{ Std. Dev. } \\
\hline $\mathrm{SiO}_{2}$ & 7.2 & 7.2 & 7.3 & 7.2 & 7.3 & 7.1 & 7.2 & 7.1 & 7.1 & 7.3 \\
\hline $\mathrm{Al}_{2} \mathrm{O}_{3}$ & 6.5 & 6.5 & 6.4 & 6.2 & 6.3 & 6.2 & 6.4 & 6.3 & 6.2 & 6.3 \\
\hline $\mathrm{MgO}$ & 7.9 & 7.6 & 7.9 & 8.0 & 7.9 & 7.8 & 7.7 & 7.6 & 7.7 & 7.6 \\
\hline $\mathrm{FeO}$ & 4.1 & 4.1 & 3.9 & 3.8 & 3.8 & 3.8 & 3.8 & 3.7 & 3.7 & 3.6 \\
\hline $\mathrm{CaO}$ & 6.3 & 6.1 & 6.2 & 6.2 & 6.0 & 6.0 & 5.9 & 5.9 & 5.9 & 5.9 \\
\hline $\mathrm{Na}_{2} \mathrm{O}$ & 1.8 & 1.8 & 1.7 & 1.7 & 1.7 & 1.7 & 1.7 & 1.7 & 1.7 & 1.7 \\
\hline $\mathrm{K}_{2} \mathrm{O}$ & 0.6 & 0.6 & 0.6 & 0.6 & 0.6 & 0.6 & 0.6 & 0.6 & 0.6 & 0.6 \\
\hline$N$ & 239 & 235 & 227 & 232 & 229 & 234 & 235 & 230 & 230 & 233 \\
\hline \multicolumn{11}{|c|}{$V_{p}=7.6 \mathrm{~km} / \mathrm{s}$} \\
\hline Mean & & & & & & & & & & \\
\hline $\mathrm{SiO}_{2}$ & 44.5 & 44.1 & 43.2 & 42.9 & 42.3 & 41.9 & 41.7 & 41.7 & 41.4 & 41.4 \\
\hline $\mathrm{Al}_{2} \mathrm{O}_{3}$ & 20.5 & 20.7 & 21.5 & 21.5 & 21.6 & 21.9 & 21.9 & 21.8 & 21.8 & 21.8 \\
\hline $\mathrm{MgO}$ & 14.5 & 14.7 & 14.4 & 14.4 & 14.9 & 14.8 & 15.1 & 15.3 & 15.7 & 15.7 \\
\hline $\mathrm{FeO}$ & 5.3 & 5.1 & 5.2 & 5.1 & 5.4 & 5.5 & 5.4 & 5.5 & 5.5 & 5.5 \\
\hline $\mathrm{CaO}$ & 10.8 & 11.2 & 11.3 & 11.5 & 11.2 & 11.3 & 11.3 & 11.2 & 11.1 & 11.1 \\
\hline $\mathrm{Na}_{2} \mathrm{O}$ & 3.4 & 3.4 & 3.6 & 3.6 & 3.6 & 3.7 & 3.7 & 3.7 & 3.7 & 3.7 \\
\hline $\mathrm{K}_{2} \mathrm{O}$ & 0.9 & 0.9 & 0.9 & 0.9 & 0.9 & 0.8 & 0.9 & 0.8 & 0.8 & 0.8 \\
\hline \multicolumn{11}{|l|}{ Std. Dev. } \\
\hline $\mathrm{SiO}_{2}$ & 7.3 & 7.1 & 7.6 & 7.6 & 7.8 & 7.9 & 7.8 & 7.8 & 7.7 & 7.6 \\
\hline $\mathrm{Al}_{2} \mathrm{O}_{3}$ & 6.4 & 6.4 & 6.8 & 6.8 & 6.8 & 6.7 & 6.7 & 6.7 & 6.7 & 6.5 \\
\hline $\mathrm{MgO}$ & 7.7 & 7.5 & 7.3 & 7.0 & 7.2 & 7.1 & 7.3 & 7.2 & 7.6 & 7.6 \\
\hline $\mathrm{FeO}$ & 3.9 & 3.6 & 3.5 & 3.5 & 3.5 & 3.5 & 3.4 & 3.5 & 3.5 & 3.4 \\
\hline $\mathrm{CaO}$ & 5.9 & 5.7 & 5.5 & 5.4 & 5.3 & 5.2 & 5.2 & 5.1 & 5.2 & 5.3 \\
\hline $\mathrm{Na}_{2} \mathrm{O}$ & 1.7 & 1.7 & 1.7 & 1.8 & 1.8 & 1.8 & 1.8 & 1.7 & 1.7 & 1.7 \\
\hline $\mathrm{K}_{2} \mathrm{O}$ & 0.7 & 0.7 & 0.7 & 0.7 & 0.7 & 0.7 & 0.7 & 0.7 & 0.7 & 0.7 \\
\hline$N$ & 205 & 208 & 228 & 240 & 251 & 263 & 259 & 260 & 258 & 264 \\
\hline
\end{tabular}

${ }^{\mathrm{a}} N$ denotes number of synthetic compositions in each $V_{p}$ bin. 
Table A.4. Mean and Standard Deviation of Major Element Oxides as a Function of $V_{p}$ for a Normal Continental Geotherm $\left(q_{s}=56 \mathrm{~mW} \mathrm{~m}^{-2}\right)$ With $P_{e q}<12 \mathrm{kbar}^{\mathrm{a}}$

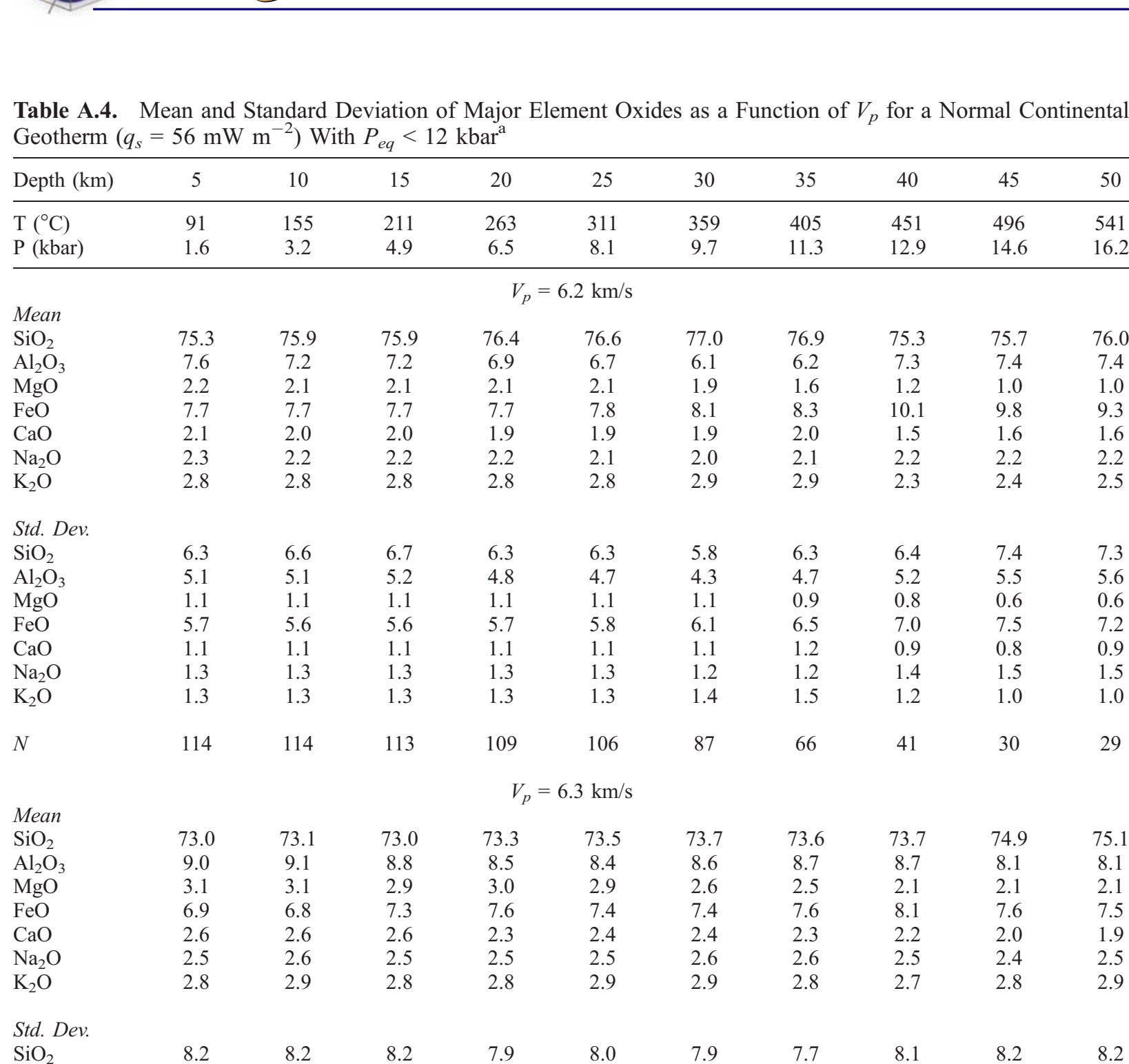

Std. Dev.

$\mathrm{Al}_{2} \mathrm{O}_{3}$

$\mathrm{MgO}$

$\mathrm{FeO}$

$\mathrm{CaO}$

$\mathrm{Na}_{2} \mathrm{O}$

$\mathrm{K}_{2} \mathrm{O}$

$$
8.2
$$

N

\section{2}

$6.9 \quad 7.0$

$$
2.0
$$

$\begin{array}{ll}2.0 & 2.0 \\ 5.2 & 5.2\end{array}$

1.6

5.2
1.6

$\begin{array}{ll}1.8 & 1.8\end{array}$

1.8
1.3

1.8
1.3

204

199

8.2
6.9
1.9
5.8
1.6
1.8
1.4

$\begin{array}{ll}7.9 & 8.0 \\ 6.8 & 6.9 \\ 1.9 & 1.8 \\ 5.9 & 5.9 \\ 1.4 & 1.4 \\ 1.7 & 1.8 \\ 1.4 & 1.4 \\ & \\ 183 & 174\end{array}$

7.9

6.8

1.7

5.8
1.4

1.4

1.7

7.7

6.3

1.7

5.9

1.4

1.6

1.7
1.4

1.4

163

148

$$
V_{p}=6.4 \mathrm{~km} / \mathrm{s}
$$

\section{Mean}

$\mathrm{SiO}_{2}$

$\mathrm{Al}_{2} \mathrm{O}_{3}$

$\mathrm{MgO}$

$\mathrm{FeO}$

$\mathrm{CaO}$

$\mathrm{Na}_{2} \mathrm{O}$

$\mathrm{K}_{2} \mathrm{O}$

$\begin{array}{cc}66.6 & 66.5 \\ 13.1 & 13.4 \\ 3.9 & 3.7 \\ 7.2 & 7.0 \\ 3.3 & 3.3 \\ 3.4 & 3.4 \\ 2.6 & 2.6\end{array}$

66.4

$\begin{array}{ll}66.8 & 67.2\end{array}$

13.6

13.4

3.7

7.1

6.9

$$
13.3
$$

68.5

$\begin{array}{cccc}69.4 & 70.8 & 71.6 & 72.2 \\ 11.7 & 10.7 & 10.1 & 9.7 \\ 3.4 & 3.2 & 3.1 & 3.1 \\ 7.2 & 6.8 & 7.1 & 6.9 \\ 2.7 & 2.6 & 2.6 & 2.5 \\ 3.1 & 3.0 & 2.8 & 2.8 \\ 2.6 & 2.8 & 2.8 & 2.9\end{array}$

Std. Dev.

$\mathrm{SiO}_{2}$

$\mathrm{Al}_{2} \mathrm{O}_{3}$

$\mathrm{MgO}$

$\begin{array}{ll}9.6 & 9.6 \\ 8.6 & 8.4 \\ 2.6 & 2.5 \\ 5.2 & 5.2\end{array}$

3.2

3.0
3.5

6.8

12.3

3.4

7.2

2.8

3.5

3.2

2.6

2.6

2.7

9.7
8.5
2.5

9.7
8.5
2.5

9.4
8.4
2.3

$\begin{array}{ll}9.6 & 9.6 \\ 8.3 & 8.2 \\ 2.1 & 2.0\end{array}$

5.2

5.0

5.0

.6
.2
5.0

$\begin{array}{lll}9.7 & 9.3 & 9.3 \\ 8.1 & 8.0 & 7.7 \\ 2.0 & 2.0 & 2.0 \\ 4.9 & 5.1 & 5.2\end{array}$


Table A.4. (continued)

\begin{tabular}{|c|c|c|c|c|c|c|c|c|c|c|}
\hline Depth $(\mathrm{km})$ & 5 & 10 & 15 & 20 & 25 & 30 & 35 & 40 & 45 & 50 \\
\hline $\mathrm{T}\left({ }^{\circ} \mathrm{C}\right)$ & 91 & 155 & 211 & 263 & 311 & 359 & 405 & 451 & 496 & 541 \\
\hline P (kbar) & 1.6 & 3.2 & 4.9 & 6.5 & 8.1 & 9.7 & 11.3 & 12.9 & 14.6 & 16.2 \\
\hline $\mathrm{CaO}$ & 2.1 & 2.1 & 1.9 & 1.8 & 1.8 & 1.6 & 1.6 & 1.6 & 1.6 & 1.6 \\
\hline $\mathrm{Na}_{2} \mathrm{O}$ & 2.2 & 2.2 & 2.2 & 2.2 & 2.2 & 2.2 & 2.2 & 2.1 & 2.0 & 2.0 \\
\hline $\mathrm{K}_{2} \mathrm{O}$ & 1.2 & 1.2 & 1.2 & 1.2 & 1.2 & 1.2 & 1.2 & 1.3 & 1.3 & 1.3 \\
\hline$N$ & 227 & 224 & 216 & 212 & 199 & 199 & 219 & 233 & 229 & 210 \\
\hline \multicolumn{11}{|c|}{$V_{p}=6.5 \mathrm{~km} / \mathrm{s}$} \\
\hline Mean & & & & & & & & & & \\
\hline $\mathrm{SiO}_{2}$ & 60.0 & 60.6 & 60.6 & 61.3 & 61.8 & 62.4 & 63.3 & 64.3 & 64.4 & 64.4 \\
\hline $\mathrm{Al}_{2} \mathrm{O}_{3}$ & 17.0 & 16.7 & 16.7 & 16.4 & 16.1 & 15.7 & 15.1 & 14.4 & 14.3 & 14.5 \\
\hline $\mathrm{MgO}$ & 4.5 & 4.6 & 4.5 & 4.2 & 4.1 & 4.2 & 4.3 & 4.3 & 4.1 & 3.8 \\
\hline $\mathrm{FeO}$ & 8.0 & 8.0 & 8.0 & 7.9 & 8.0 & 8.0 & 8.0 & 7.7 & 7.9 & 7.9 \\
\hline $\mathrm{CaO}$ & 4.3 & 4.1 & 4.0 & 3.9 & 3.8 & 3.6 & 3.2 & 3.1 & 3.1 & 3.1 \\
\hline $\mathrm{Na}_{2} \mathrm{O}$ & 4.0 & 4.0 & 4.0 & 4.0 & 3.9 & 3.9 & 3.8 & 3.7 & 3.7 & 3.8 \\
\hline $\mathrm{K}_{2} \mathrm{O}$ & 2.1 & 2.1 & 2.1 & 2.2 & 2.2 & 2.3 & 2.3 & 2.5 & 2.4 & 2.5 \\
\hline \multicolumn{11}{|l|}{ Std. Dev. } \\
\hline $\mathrm{SiO}_{2}$ & 9.6 & 9.6 & 9.8 & 10.1 & 10.3 & 10.5 & 11.3 & 11.6 & 11.5 & 11.6 \\
\hline $\mathrm{Al}_{2} \mathrm{O}_{3}$ & 8.2 & 8.3 & 8.4 & 8.3 & 8.4 & 8.5 & 9.2 & 9.4 & 9.2 & 9.2 \\
\hline $\mathrm{MgO}$ & 3.0 & 3.0 & 2.8 & 2.8 & 2.8 & 2.8 & 2.7 & 2.7 & 2.8 & 2.6 \\
\hline $\mathrm{FeO}$ & 5.8 & 5.7 & 5.8 & 5.7 & 5.7 & 5.8 & 5.7 & 5.8 & 5.9 & 6.0 \\
\hline $\mathrm{CaO}$ & 2.8 & 2.7 & 2.6 & 2.5 & 2.5 & 2.4 & 2.0 & 2.0 & 2.0 & 2.0 \\
\hline $\mathrm{Na}_{2} \mathrm{O}$ & 2.2 & 2.2 & 2.2 & 2.2 & 2.2 & 2.2 & 2.4 & 2.4 & 2.4 & 2.3 \\
\hline $\mathrm{K}_{2} \mathrm{O}$ & 1.1 & 1.1 & 1.1 & 1.1 & 1.1 & 1.1 & 1.1 & 1.2 & 1.2 & 1.2 \\
\hline$N$ & 307 & 307 & 291 & 295 & 284 & 284 & 267 & 272 & 274 & 263 \\
\hline \multicolumn{11}{|c|}{$V_{p}=6.6 \mathrm{~km} / \mathrm{s}$} \\
\hline Mean & & & & & & & & & & \\
\hline $\mathrm{SiO}_{2}$ & 58.0 & 58.1 & 58.5 & 58.6 & 58.7 & 58.5 & 58.4 & 58.2 & 58.2 & 58.5 \\
\hline $\mathrm{Al}_{2} \mathrm{O}_{3}$ & 17.6 & 17.5 & 17.1 & 17.1 & 17.2 & 17.6 & 17.7 & 17.8 & 17.9 & 17.9 \\
\hline $\mathrm{MgO}$ & 5.5 & 5.5 & 5.5 & 5.5 & 5.3 & 5.1 & 5.1 & 5.1 & 5.0 & 4.7 \\
\hline $\mathrm{FeO}$ & 8.2 & 8.3 & 8.3 & 8.3 & 8.4 & 8.2 & 8.4 & 8.5 & 8.5 & 8.7 \\
\hline $\mathrm{CaO}$ & 5.0 & 4.8 & 4.7 & 4.7 & 4.7 & 4.6 & 4.3 & 4.2 & 4.1 & 4.0 \\
\hline $\mathrm{Na}_{2} \mathrm{O}$ & 3.9 & 4.0 & 3.9 & 3.9 & 4.0 & 4.1 & 4.1 & 4.2 & 4.3 & 4.3 \\
\hline $\mathrm{K}_{2} \mathrm{O}$ & 1.8 & 1.8 & 1.8 & 1.9 & 1.9 & 1.9 & 1.9 & 1.9 & 2.0 & 2.0 \\
\hline \multicolumn{11}{|l|}{ Std. Dev. } \\
\hline $\mathrm{SiO}_{2}$ & 9.7 & 9.9 & 10.0 & 10.0 & 10.4 & 10.2 & 10.3 & 10.5 & 10.5 & 10.8 \\
\hline $\mathrm{Al}_{2} \mathrm{O}_{3}$ & 8.2 & 8.4 & 8.4 & 8.3 & 8.6 & 8.4 & 8.5 & 8.5 & 8.5 & 8.8 \\
\hline $\mathrm{MgO}$ & 3.4 & 3.4 & 3.4 & 3.4 & 3.3 & 3.3 & 3.3 & 3.3 & 3.2 & 3.1 \\
\hline $\mathrm{FeO}$ & 5.7 & 5.7 & 5.8 & 5.7 & 5.7 & 5.9 & 6.0 & 5.9 & 6.0 & 6.0 \\
\hline $\mathrm{CaO}$ & 3.0 & 3.0 & 2.9 & 2.9 & 2.9 & 2.9 & 2.8 & 2.7 & 2.7 & 2.6 \\
\hline $\mathrm{Na}_{2} \mathrm{O}$ & 2.2 & 2.2 & 2.2 & 2.2 & 2.3 & 2.2 & 2.2 & 2.2 & 2.2 & 2.3 \\
\hline $\mathrm{K}_{2} \mathrm{O}$ & 1.1 & 1.1 & 1.1 & 1.1 & 1.1 & 1.1 & 1.1 & 1.1 & 1.1 & 1.1 \\
\hline$N$ & 426 & 419 & 408 & 399 & 395 & 395 & 372 & 363 & 355 & 347 \\
\hline \multicolumn{11}{|c|}{$V_{p}=6.7 \mathrm{~km} / \mathrm{s}$} \\
\hline \multicolumn{11}{|l|}{ Mean } \\
\hline $\mathrm{SiO}_{2}$ & 55.9 & 55.7 & 55.8 & 56.0 & 56.1 & 56.2 & 56.1 & 56.1 & 56.1 & 56.9 \\
\hline $\mathrm{Al}_{2} \mathrm{O}_{3}$ & 18.1 & 18.2 & 18.2 & 18.0 & 18.1 & 18.1 & 18.5 & 18.5 & 18.5 & 18.0 \\
\hline $\mathrm{MgO}$ & 6.9 & 6.8 & 6.7 & 6.6 & 6.4 & 6.1 & 5.9 & 5.9 & 5.8 & 5.8 \\
\hline $\mathrm{FeO}$ & 8.3 & 8.4 & 8.5 & 8.6 & 8.6 & 8.7 & 8.7 & 8.7 & 8.9 & 8.7 \\
\hline $\mathrm{CaO}$ & 5.4 & 5.5 & 5.4 & 5.2 & 5.3 & 5.3 & 5.2 & 4.9 & 4.8 & 4.8 \\
\hline $\mathrm{Na}_{2} \mathrm{O}$ & 3.9 & 3.9 & 4.0 & 4.0 & 4.0 & 4.0 & 4.1 & 4.2 & 4.2 & 4.1 \\
\hline $\mathrm{K}_{2} \mathrm{O}$ & 1.5 & 1.5 & 1.5 & 1.6 & 1.6 & 1.6 & 1.6 & 1.6 & 1.7 & 1.7 \\
\hline
\end{tabular}


Table A.4. (continued)

\begin{tabular}{|c|c|c|c|c|c|c|c|c|c|c|}
\hline Depth (km) & 5 & 10 & 15 & 20 & 25 & 30 & 35 & 40 & 45 & 50 \\
\hline $\mathrm{T}\left({ }^{\circ} \mathrm{C}\right)$ & 91 & 155 & 211 & 263 & 311 & 359 & 405 & 451 & 496 & 541 \\
\hline P (kbar) & 1.6 & 3.2 & 4.9 & 6.5 & 8.1 & 9.7 & 11.3 & 12.9 & 14.6 & 16.2 \\
\hline \multicolumn{11}{|l|}{ Std. Dev. } \\
\hline $\mathrm{SiO}_{2}$ & 9.9 & 9.9 & 10.0 & 10.2 & 10.2 & 10.3 & 10.2 & 10.2 & 10.2 & 10.3 \\
\hline $\mathrm{Al}_{2} \mathrm{O}_{3}$ & 8.5 & 8.4 & 8.5 & 8.6 & 8.5 & 8.6 & 8.3 & 8.2 & 8.3 & 8.4 \\
\hline $\mathrm{MgO}$ & 3.5 & 3.5 & 3.6 & 3.6 & 3.4 & 3.3 & 3.4 & 3.3 & 3.3 & 3.3 \\
\hline $\mathrm{FeO}$ & 5.4 & 5.4 & 5.4 & 5.5 & 5.5 & 5.5 & 5.6 & 5.7 & 5.7 & 5.6 \\
\hline $\mathrm{CaO}$ & 3.4 & 3.4 & 3.4 & 3.3 & 3.2 & 3.3 & 3.2 & 3.0 & 2.9 & 2.9 \\
\hline $\mathrm{Na}_{2} \mathrm{O}$ & 2.4 & 2.3 & 2.3 & 2.3 & 2.3 & 2.4 & 2.3 & 2.2 & 2.2 & 2.2 \\
\hline $\mathrm{K}_{2} \mathrm{O}$ & 1.0 & 1.0 & 1.0 & 1.0 & 1.0 & 1.0 & 1.0 & 1.0 & 1.0 & 1.0 \\
\hline$N$ & 485 & 492 & 491 & 479 & 480 & 478 & 477 & 472 & 458 & 460 \\
\hline \multicolumn{11}{|c|}{$V_{p}=6.8 \mathrm{~km} / \mathrm{s}$} \\
\hline \multicolumn{11}{|l|}{ Mean } \\
\hline $\mathrm{SiO}_{2}$ & 54.3 & 54.5 & 54.4 & 54.3 & 54.4 & 54.8 & 55.0 & 55.2 & 55.2 & 55 \\
\hline $\mathrm{Al}_{2} \mathrm{O}_{3}$ & 18.3 & 18.1 & 18.5 & 18.7 & 18.5 & 18.3 & 18.0 & 18.0 & 18.2 & 18 \\
\hline $\mathrm{MgO}$ & 8.3 & 8.4 & 8.1 & 7.9 & 7.9 & 7.9 & 7.8 & 7.6 & 7.4 & 7.2 \\
\hline $\mathrm{FeO}$ & 7.8 & 7.8 & 7.8 & 8.1 & 8.0 & 8.1 & 8.2 & 8.2 & 8.1 & 8.1 \\
\hline $\mathrm{CaO}$ & 6.1 & 6.1 & 6.0 & 5.9 & 5.8 & 5.7 & 5.8 & 5.7 & 5.6 & 5.6 \\
\hline $\mathrm{Na}_{2} \mathrm{O}$ & 3.8 & 3.7 & 3.8 & 3.9 & 3.9 & 3.8 & 3.8 & 3.8 & 3.9 & 3.9 \\
\hline $\mathrm{K}_{2} \mathrm{O}$ & 1.4 & 1.4 & 1.4 & 1.4 & 1.4 & 1.4 & 1.5 & 1.5 & 1.5 & 1.5 \\
\hline
\end{tabular}

Std. Dev.

$\mathrm{SiO}_{2}$

$\mathrm{Al}_{2} \mathrm{O}_{3}$

$\mathrm{MgO}$

$\mathrm{FeO}$

$\mathrm{CaO}$

$\mathrm{Na}_{2} \mathrm{O}$

$\mathrm{K}_{2} \mathrm{O}$

N

Mean

$\mathrm{SiO}_{2}$

$\mathrm{Al}_{2} \mathrm{O}_{3}$

$\mathrm{MgO}$

$\mathrm{FeO}$

$\mathrm{CaO}$

$\mathrm{Na}_{2} \mathrm{O}$

$\mathrm{K}_{2} \mathrm{O}$

Std. Dev.

$\mathrm{SiO}_{2}$

$\mathrm{Al}_{2} \mathrm{O}_{3}$

$\mathrm{MgO}$

$\mathrm{FeO}$

$\mathrm{CaO}$

$\mathrm{Na}_{2} \mathrm{O}$

$\mathrm{K}_{2} \mathrm{O}$

N

Mean

$\mathrm{SiO}_{2}$

$\mathrm{Al}_{2} \mathrm{O}_{3}$

$\mathrm{MgO}$
542

552

547

9.7

8.3

4.0

5.2

3.8

2.3
0.9

2.3

0.9

53.2

18.1

9.8

7.1

6.9

3.6
1.3

53.3

18.0

9.8

7.2

6.7

3.6

1.4

9.1

8.1

4.9

4.8

4.4

2.2

0.8

9.1

8.2

4.8

4.8

4.2

2.2

0.8

537

528

\section{7}

17.8

9.8

7.1

6.7

3.5
1.4

1.4

9.8
8.4
3.8
5.3
3.7
2.4
0.8

\section{8}

\section{4}

3.8

5.3

3.7

$$
2.3
$$

$536 \quad 542$

$$
V_{p}=6.9 \mathrm{~km} / \mathrm{s}
$$

$\begin{array}{ccccccc}53.6 & 53.8 & 54.0 & 54.5 & 54.8 & 55.2 & 54.9 \\ 18.1 & 17.9 & 17.9 & 17.5 & 17.4 & 17.3 & 17.6 \\ 9.6 & 9.7 & 9.6 & 9.5 & 9.2 & 9.1 & 9.1 \\ 7.1 & 7.2 & 7.1 & 7.0 & 7.0 & 6.9 & 7.1 \\ 6.7 & 6.5 & 6.5 & 6.5 & 6.6 & 6.6 & 6.4 \\ 3.6 & 3.6 & 3.6 & 3.5 & 3.5 & 3.4 & 3.5 \\ 1.4 & 1.4 & 1.4 & 1.5 & 1.5 & 1.5 & 1.5\end{array}$

$\begin{array}{llllllll}9.1 & 9.0 & 9.1 & 9.1 & 9.1 & 9.3 & 9.2 & 9.4 \\ 8.1 & 8.0 & 8.1 & 8.1 & 8.1 & 8.2 & 8.2 & 8.3 \\ 4.8 & 4.7 & 4.8 & 4.7 & 4.6 & 4.6 & 4.5 & 4.5 \\ 4.8 & 4.8 & 4.8 & 4.7 & 4.6 & 4.6 & 4.5 & 4.7 \\ 4.2 & 4.2 & 4.2 & 4.1 & 4.0 & 4.0 & 3.8 & 3.8 \\ 2.1 & 2.1 & 2.2 & 2.1 & 2.1 & 2.2 & 2.2 & 2.2 \\ 0.9 & 0.8 & 0.8 & 0.9 & 0.8 & 0.9 & 0.8 & 0.9 \\ 544 & 556 & 551 & 559 & 578 & 570 & 556 & 555\end{array}$

$$
V_{p}=7.0 \mathrm{~km} / \mathrm{s}
$$

$\begin{array}{llllllllll}51.4 & 51.3 & 51.7 & 52.1 & 52.2 & 52.3 & 52.4 & 52.5 & 53.0 & 53.1 \\ 18.2 & 18.4 & 18.0 & 17.8 & 17.8 & 17.9 & 18.0 & 17.9 & 17.6 & 17.8 \\ 11.4 & 11.3 & 11.3 & 11.2 & 11.0 & 10.9 & 10.8 & 10.6 & 10.5 & 10.5\end{array}$

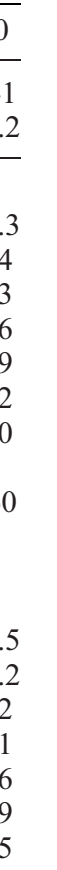


Table A.4. (continued)

\begin{tabular}{|c|c|c|c|c|c|c|c|c|c|c|}
\hline Depth $(\mathrm{km})$ & 5 & 10 & 15 & 20 & 25 & 30 & 35 & 40 & 45 & 50 \\
\hline $\mathrm{T}\left({ }^{\circ} \mathrm{C}\right)$ & 91 & 155 & 211 & 263 & 311 & 359 & 405 & 451 & 496 & 541 \\
\hline P (kbar) & 1.6 & 3.2 & 4.9 & 6.5 & 8.1 & 9.7 & 11.3 & 12.9 & 14.6 & 16.2 \\
\hline $\mathrm{FeO}$ & 7.0 & 7.1 & 7.1 & 7.0 & 7.0 & 6.9 & 6.9 & 7.1 & 7.0 & 7.1 \\
\hline $\mathrm{CaO}$ & 7.3 & 7.3 & 7.3 & 7.3 & 7.3 & 7.3 & 7.3 & 7.1 & 7.1 & 6.8 \\
\hline $\mathrm{Na}_{2} \mathrm{O}$ & 3.4 & 3.5 & 3.4 & 3.4 & 3.4 & 3.4 & 3.4 & 3.5 & 3.4 & 3.5 \\
\hline $\mathrm{K}_{2} \mathrm{O}$ & 1.1 & 1.1 & 1.2 & 1.2 & 1.2 & 1.2 & 1.3 & 1.3 & 1.3 & 1.3 \\
\hline \multicolumn{11}{|l|}{ Std. Dev. } \\
\hline $\mathrm{SiO}_{2}$ & 8.5 & 8.5 & 8.5 & 8.6 & 8.6 & 8.6 & 8.7 & 8.7 & 9.0 & 9.1 \\
\hline $\mathrm{Al}_{2} \mathrm{O}_{3}$ & 7.9 & 7.9 & 7.9 & 7.9 & 7.9 & 7.9 & 7.8 & 7.9 & 8.1 & 8.1 \\
\hline $\mathrm{MgO}$ & 5.3 & 5.4 & 5.4 & 5.4 & 5.5 & 5.5 & 5.5 & 5.4 & 5.2 & 5.2 \\
\hline $\mathrm{FeO}$ & 4.7 & 4.7 & 4.7 & 4.7 & 4.7 & 4.6 & 4.6 & 4.6 & 4.5 & 4.6 \\
\hline $\mathrm{CaO}$ & 4.8 & 4.8 & 4.7 & 4.7 & 4.7 & 4.7 & 4.7 & 4.5 & 4.4 & 4.2 \\
\hline $\mathrm{Na}_{2} \mathrm{O}$ & 2.1 & 2.0 & 2.0 & 2.0 & 2.0 & 2.0 & 2.0 & 2.0 & 2.1 & 2.1 \\
\hline $\mathrm{K}_{2} \mathrm{O}$ & 0.8 & 0.8 & 0.8 & 0.8 & 0.8 & 0.8 & 0.8 & 0.8 & 0.8 & 0.9 \\
\hline$N$ & 471 & 468 & 489 & 512 & 506 & 520 & 521 & 518 & 528 & 536 \\
\hline \multicolumn{11}{|c|}{$V_{p}=7.1 \mathrm{~km} / \mathrm{s}$} \\
\hline Mean & & & & & & & & & & \\
\hline $\mathrm{SiO}_{2}$ & 49.8 & 50.0 & 49.8 & 50.1 & 50.1 & 50.2 & 49.9 & 50.2 & 50.2 & 50.5 \\
\hline $\mathrm{Al}_{2} \mathrm{O}_{3}$ & 18.2 & 18.1 & 18.4 & 18.2 & 18.3 & 18.3 & 18.5 & 18.5 & 18.7 & 18.6 \\
\hline $\mathrm{MgO}$ & 13.1 & 13.0 & 12.8 & 12.7 & 12.6 & 12.8 & 12.5 & 12.3 & 11.9 & 11.8 \\
\hline $\mathrm{FeO}$ & 7.0 & 7.0 & 7.0 & 6.9 & 6.9 & 7.0 & 7.2 & 7.1 & 7.2 & 7.2 \\
\hline $\mathrm{CaO}$ & 7.5 & 7.7 & 7.7 & 7.7 & 7.7 & 7.4 & 7.4 & 7.3 & 7.4 & 7.4 \\
\hline $\mathrm{Na}_{2} \mathrm{O}$ & 3.3 & 3.3 & 3.4 & 3.3 & 3.4 & 3.4 & 3.5 & 3.5 & 3.5 & 3.5 \\
\hline $\mathrm{K}_{2} \mathrm{O}$ & 1.0 & 1.0 & 1.0 & 1.0 & 1.0 & 1.0 & 1.0 & 1.0 & 1.0 & 1.0 \\
\hline \multicolumn{11}{|l|}{ Std. Dev. } \\
\hline $\mathrm{SiO}_{2}$ & 8.1 & 8.1 & 8.1 & 8.3 & 8.3 & 8.3 & 8.5 & 8.6 & 8.7 & 8.7 \\
\hline $\mathrm{Al}_{2} \mathrm{O}_{3}$ & 7.7 & 7.7 & 7.7 & 7.7 & 7.7 & 7.8 & 7.8 & 7.8 & 7.9 & 7.8 \\
\hline $\mathrm{MgO}$ & 5.7 & 5.8 & 5.8 & 5.8 & 5.7 & 5.7 & 5.7 & 5.6 & 5.5 & 5.5 \\
\hline $\mathrm{FeO}$ & 5.0 & 4.9 & 4.9 & 5.0 & 4.9 & 5.0 & 5.0 & 5.0 & 5.0 & 5.0 \\
\hline $\mathrm{CaO}$ & 5.1 & 5.2 & 5.2 & 5.2 & 5.0 & 5.0 & 5.0 & 4.9 & 4.9 & 4.9 \\
\hline $\mathrm{Na}_{2} \mathrm{O}$ & 2.0 & 2.0 & 2.0 & 2.0 & 2.0 & 2.0 & 2.0 & 2.0 & 2.0 & 2.0 \\
\hline $\mathrm{K}_{2} \mathrm{O}$ & 0.7 & 0.7 & 0.7 & 0.7 & 0.7 & 0.7 & 0.7 & 0.7 & 0.7 & 0.7 \\
\hline$N$ & 422 & 438 & 435 & 445 & 455 & 459 & 448 & 466 & 488 & 497 \\
\hline \multicolumn{11}{|c|}{$V_{p}=7.2 \mathrm{~km} / \mathrm{s}$} \\
\hline Mean & & & & & & & & & & \\
\hline $\mathrm{SiO}_{2}$ & 48.7 & 48.8 & 48.5 & 48.5 & 48.9 & 48.9 & 49.1 & 49.5 & 49.5 & 49.7 \\
\hline $\mathrm{Al}_{2} \mathrm{O}_{3}$ & 18.2 & 18.2 & 18.5 & 18.6 & 18.4 & 18.4 & 18.3 & 18.2 & 18.1 & 17.9 \\
\hline $\mathrm{MgO}$ & 13.9 & 13.8 & 13.7 & 13.6 & 13.6 & 13.6 & 13.6 & 13.6 & 13.5 & 13.5 \\
\hline $\mathrm{FeO}$ & 6.9 & 6.8 & 6.7 & 6.7 & 6.7 & 6.7 & 6.6 & 6.5 & 6.7 & 6.7 \\
\hline $\mathrm{CaO}$ & 8.2 & 8.3 & 8.3 & 8.3 & 8.3 & 8.2 & 8.2 & 8.2 & 8.1 & 8.0 \\
\hline $\mathrm{Na}_{2} \mathrm{O}$ & 3.2 & 3.2 & 3.3 & 3.3 & 3.2 & 3.2 & 3.2 & 3.2 & 3.2 & 3.2 \\
\hline $\mathrm{K}_{2} \mathrm{O}$ & 0.9 & 0.9 & 0.9 & 0.9 & 0.9 & 0.9 & 0.9 & 0.9 & 0.9 & 1.0 \\
\hline \multicolumn{11}{|l|}{ Std. Dev. } \\
\hline $\mathrm{SiO}_{2}$ & 7.9 & 7.9 & 8.0 & 8.0 & 8.0 & 8.0 & 7.9 & 7.9 & 7.8 & 7.9 \\
\hline $\mathrm{Al}_{2} \mathrm{O}_{3}$ & 7.8 & 7.8 & 7.9 & 7.9 & 7.7 & 7.8 & 7.7 & 7.6 & 7.5 & 7.5 \\
\hline $\mathrm{MgO}$ & 6.3 & 6.3 & 6.3 & 6.2 & 6.1 & 6.1 & 6.1 & 6.1 & 6.1 & 6.0 \\
\hline $\mathrm{FeO}$ & 4.8 & 4.8 & 4.8 & 4.8 & 4.7 & 4.7 & 4.8 & 4.7 & 4.9 & 4.9 \\
\hline $\mathrm{CaO}$ & 5.4 & 5.5 & 5.5 & 5.4 & 5.3 & 5.2 & 5.3 & 5.3 & 5.3 & 5.2 \\
\hline $\mathrm{Na}_{2} \mathrm{O}$ & 1.9 & 2.0 & 2.0 & 2.0 & 1.9 & 1.9 & 1.9 & 1.9 & 1.9 & 1.9 \\
\hline $\mathrm{K}_{2} \mathrm{O}$ & 0.6 & 0.6 & 0.6 & 0.6 & 0.6 & 0.6 & 0.6 & 0.6 & 0.6 & 0.6 \\
\hline$N$ & 335 & 343 & 344 & 350 & 367 & 361 & 379 & 404 & 421 & 437 \\
\hline
\end{tabular}


Table A.4. (continued)

\begin{tabular}{|c|c|c|c|c|c|c|c|c|c|c|}
\hline Depth (km) & 5 & 10 & 15 & 20 & 25 & 30 & 35 & 40 & 45 & 50 \\
\hline $\mathrm{T}\left({ }^{\circ} \mathrm{C}\right)$ & 91 & 155 & 211 & 263 & 311 & 359 & 405 & 451 & 496 & 541 \\
\hline P (kbar) & 1.6 & 3.2 & 4.9 & 6.5 & 8.1 & 9.7 & 11.3 & 12.9 & 14.6 & 16.2 \\
\hline \multicolumn{11}{|c|}{$V_{p}=7.3 \mathrm{~km} / \mathrm{s}$} \\
\hline Mean & & & & & & & & & & \\
\hline $\mathrm{SiO}_{2}$ & 46.6 & 46.5 & 46.6 & 47.0 & 47.2 & 47.3 & 47.9 & 48.0 & 48.2 & 47.9 \\
\hline $\mathrm{Al}_{2} \mathrm{O}_{3}$ & 19.4 & 19.6 & 19.4 & 19.2 & 19.1 & 19.1 & 18.7 & 18.6 & 18.4 & 18.8 \\
\hline $\mathrm{MgO}$ & 14.0 & 13.9 & 14.0 & 13.9 & 13.8 & 13.6 & 13.8 & 13.8 & 13.9 & 13.9 \\
\hline $\mathrm{FeO}$ & 6.3 & 6.2 & 6.2 & 6.1 & 6.2 & 6.2 & 6.0 & 6.1 & 6.0 & 6.0 \\
\hline $\mathrm{CaO}$ & 9.8 & 9.9 & 9.8 & 9.9 & 9.8 & 9.9 & 9.9 & 9.8 & 9.7 & 9.4 \\
\hline $\mathrm{Na}_{2} \mathrm{O}$ & 3.2 & 3.2 & 3.2 & 3.1 & 3.1 & 3.1 & 3.0 & 3.0 & 3.0 & 3.1 \\
\hline $\mathrm{K}_{2} \mathrm{O}$ & 0.8 & 0.8 & 0.8 & 0.8 & 0.8 & 0.8 & 0.8 & 0.8 & 0.8 & 0.8 \\
\hline \multicolumn{11}{|l|}{ Std. Dev. } \\
\hline $\mathrm{SiO}_{2}$ & 6.7 & 6.6 & 6.7 & 6.9 & 7.1 & 7.1 & 7.2 & 7.2 & 7.2 & 7.3 \\
\hline $\mathrm{Al}_{2} \mathrm{O}_{3}$ & 7.8 & 7.7 & 7.8 & 7.8 & 7.8 & 7.8 & 7.8 & 7.7 & 7.6 & 7.7 \\
\hline $\mathrm{MgO}$ & 6.9 & 6.9 & 6.9 & 6.7 & 6.8 & 6.8 & 6.7 & 6.8 & 6.8 & 7.0 \\
\hline $\mathrm{FeO}$ & 4.0 & 4.1 & 4.1 & 4.1 & 4.1 & 4.1 & 4.1 & 4.2 & 4.3 & 4.2 \\
\hline $\mathrm{CaO}$ & 5.8 & 5.8 & 5.7 & 5.7 & 5.6 & 5.7 & 5.6 & 5.7 & 5.7 & 5.8 \\
\hline $\mathrm{Na}_{2} \mathrm{O}$ & 1.7 & 1.7 & 1.7 & 1.8 & 1.8 & 1.8 & 1.8 & 1.8 & 1.7 & 1.7 \\
\hline $\mathrm{K}_{2} \mathrm{O}$ & 0.5 & 0.5 & 0.5 & 0.5 & 0.5 & 0.5 & 0.5 & 0.5 & 0.5 & 0.5 \\
\hline$N$ & 282 & 276 & 284 & 291 & 297 & 303 & 325 & 334 & 348 & 334 \\
\hline \multicolumn{11}{|c|}{$V_{p}=7.4 \mathrm{~km} / \mathrm{s}$} \\
\hline Mean & & & & & & & & & & \\
\hline $\mathrm{SiO}_{2}$ & 45.7 & 45.7 & 46.1 & 46.1 & 46.0 & 46.0 & 46.0 & 46.0 & 45.9 & 46.2 \\
\hline $\mathrm{Al}_{2} \mathrm{O}_{3}$ & 19.3 & 19.2 & 18.9 & 18.9 & 19.0 & 19.2 & 19.3 & 19.4 & 19.5 & 19.4 \\
\hline $\mathrm{MgO}$ & 15.3 & 15.3 & 15.3 & 15.4 & 15.3 & 14.9 & 14.9 & 14.7 & 14.7 & 14.4 \\
\hline $\mathrm{FeO}$ & 5.6 & 5.6 & 5.6 & 5.6 & 5.6 & 5.7 & 5.7 & 5.5 & 5.6 & 5.5 \\
\hline $\mathrm{CaO}$ & 10.4 & 10.4 & 10.4 & 10.4 & 10.4 & 10.6 & 10.5 & 10.6 & 10.5 & 10.8 \\
\hline $\mathrm{Na}_{2} \mathrm{O}$ & 3.0 & 3.0 & 2.9 & 2.9 & 3.0 & 3.0 & 3.0 & 3.0 & 3.1 & 3.0 \\
\hline $\mathrm{K}_{2} \mathrm{O}$ & 0.7 & 0.7 & 0.7 & 0.7 & 0.7 & 0.7 & 0.7 & 0.7 & 0.7 & 0.7 \\
\hline \multicolumn{11}{|l|}{ Std. Dev. } \\
\hline $\mathrm{SiO}_{2}$ & 6.1 & 6.1 & 6.1 & 6.0 & 6.1 & 6.0 & 6.1 & 6.1 & 6.1 & 6.2 \\
\hline $\mathrm{Al}_{2} \mathrm{O}_{3}$ & 7.4 & 7.3 & 7.2 & 7.2 & 7.2 & 7.2 & 7.2 & 7.1 & 7.1 & 7.0 \\
\hline $\mathrm{MgO}$ & 7.3 & 7.3 & 7.3 & 7.3 & 7.3 & 7.4 & 7.3 & 7.4 & 7.4 & 7.5 \\
\hline $\mathrm{FeO}$ & 3.8 & 3.8 & 3.8 & 3.8 & 3.7 & 3.7 & 3.7 & 3.7 & 3.8 & 3.7 \\
\hline $\mathrm{CaO}$ & 6.0 & 5.9 & 5.9 & 5.9 & 5.9 & 6.0 & 6.0 & 6.0 & 6.0 & 6.0 \\
\hline $\mathrm{Na}_{2} \mathrm{O}$ & 1.7 & 1.7 & 1.6 & 1.6 & 1.6 & 1.6 & 1.6 & 1.6 & 1.6 & 1.6 \\
\hline $\mathrm{K}_{2} \mathrm{O}$ & 0.5 & 0.5 & 0.5 & 0.5 & 0.5 & 0.5 & 0.5 & 0.5 & 0.5 & 0.5 \\
\hline$N$ & 240 & 240 & 247 & 250 & 250 & 252 & 252 & 256 & 248 & 258 \\
\hline \multicolumn{11}{|c|}{$V_{p}=7.5 \mathrm{~km} / \mathrm{s}$} \\
\hline Mean & & & & & & & & & & \\
\hline $\mathrm{SiO}_{2}$ & 45.3 & 45.1 & 45.1 & 45.0 & 45.1 & 45.1 & 45.1 & 45.2 & 45.1 & 45.8 \\
\hline $\mathrm{Al}_{2} \mathrm{O}_{3}$ & 18.6 & 18.7 & 18.8 & 18.7 & 18.8 & 18.8 & 18.8 & 18.8 & 18.8 & 18.3 \\
\hline $\mathrm{MgO}$ & 16.8 & 16.8 & 16.8 & 17.0 & 16.6 & 16.6 & 16.7 & 16.7 & 16.7 & 16.5 \\
\hline $\mathrm{FeO}$ & 5.0 & 5.1 & 5.0 & 5.1 & 5.1 & 5.0 & 5.0 & 5.0 & 5.0 & 5.1 \\
\hline $\mathrm{CaO}$ & 10.7 & 10.8 & 10.8 & 10.7 & 11.0 & 10.9 & 10.8 & 10.8 & 10.8 & 10.9 \\
\hline $\mathrm{Na}_{2} \mathrm{O}$ & 2.8 & 2.8 & 2.8 & 2.8 & 2.8 & 2.8 & 2.8 & 2.8 & 2.9 & 2.7 \\
\hline $\mathrm{K}_{2} \mathrm{O}$ & 0.7 & 0.7 & 0.7 & 0.7 & 0.7 & 0.7 & 0.7 & 0.7 & 0.7 & 0.7 \\
\hline \multicolumn{11}{|l|}{ Std. Dev. } \\
\hline $\mathrm{SiO}_{2}$ & 5.6 & 5.6 & 5.7 & 5.7 & 5.5 & 5.5 & 5.5 & 5.5 & 5.5 & 5.8 \\
\hline $\mathrm{Al}_{2} \mathrm{O}_{3}$ & 6.2 & 6.1 & 6.1 & 6.1 & 5.9 & 5.9 & 5.9 & 5.9 & 5.8 & 6.1 \\
\hline $\mathrm{MgO}$ & 8.0 & 7.8 & 7.9 & 7.8 & 7.9 & 7.9 & 7.8 & 7.8 & 7.8 & 7.5 \\
\hline $\mathrm{FeO}$ & 3.0 & 3.0 & 3.0 & 3.0 & 2.9 & 3.0 & 2.9 & 2.9 & 2.9 & 3.2 \\
\hline $\mathrm{CaO}$ & 6.4 & 6.2 & 6.3 & 6.3 & 6.3 & 6.3 & 6.3 & 6.3 & 6.2 & 6.0 \\
\hline
\end{tabular}


Table A.4. (continued)

\begin{tabular}{|c|c|c|c|c|c|c|c|c|c|c|}
\hline Depth $(\mathrm{km})$ & 5 & 10 & 15 & 20 & 25 & 30 & 35 & 40 & 45 & 50 \\
\hline $\mathrm{T}\left({ }^{\circ} \mathrm{C}\right)$ & 91 & 155 & 211 & 263 & 311 & 359 & 405 & 451 & 496 & 541 \\
\hline P (kbar) & 1.6 & 3.2 & 4.9 & 6.5 & 8.1 & 9.7 & 11.3 & 12.9 & 14.6 & 16.2 \\
\hline $\mathrm{Na}_{2} \mathrm{O}$ & 1.7 & 1.6 & 1.6 & 1.6 & 1.6 & 1.6 & 1.6 & 1.6 & 1.5 & 1.6 \\
\hline $\mathrm{K}_{2} \mathrm{O}$ & 0.5 & 0.5 & 0.5 & 0.5 & 0.5 & 0.5 & 0.5 & 0.5 & 0.5 & 0.5 \\
\hline$N$ & 156 & 167 & 164 & 168 & 177 & 177 & 178 & 181 & 184 & 209 \\
\hline \multicolumn{11}{|c|}{$V_{p}=7.6 \mathrm{~km} / \mathrm{s}$} \\
\hline \multicolumn{11}{|l|}{ Mean } \\
\hline $\mathrm{SiO}_{2}$ & 41.9 & 42.0 & 42.1 & 42.1 & 42.2 & 42.7 & 42.6 & 42.6 & 42.4 & 42.3 \\
\hline $\mathrm{Al}_{2} \mathrm{O}_{3}$ & 21.8 & 21.7 & 21.5 & 21.6 & 21.5 & 21.1 & 21.1 & 21.0 & 21.3 & 21.4 \\
\hline $\mathrm{MgO}$ & 15.3 & 15.3 & 15.4 & 15.4 & 15.4 & 15.8 & 15.8 & 15.7 & 15.4 & 15.3 \\
\hline $\mathrm{FeO}$ & 4.0 & 4.0 & 4.1 & 4.1 & 4.0 & 4.0 & 4.0 & 4.1 & 4.4 & 4.4 \\
\hline $\mathrm{CaO}$ & 12.7 & 12.7 & 12.6 & 12.7 & 12.7 & 12.5 & 12.4 & 12.4 & 12.4 & 12.5 \\
\hline $\mathrm{Na}_{2} \mathrm{O}$ & 3.4 & 3.4 & 3.3 & 3.4 & 3.3 & 3.2 & 3.3 & 3.2 & 3.3 & 3.3 \\
\hline $\mathrm{K}_{2} \mathrm{O}$ & 0.9 & 0.9 & 0.9 & 0.9 & 0.9 & 0.9 & 0.9 & 0.9 & 0.8 & 0.8 \\
\hline \multicolumn{11}{|l|}{ Std. Dev. } \\
\hline $\mathrm{SiO}_{2}$ & 4.9 & 4.8 & 5.0 & 5.0 & 5.0 & 5.3 & 5.3 & 5.5 & 6.2 & 6.2 \\
\hline $\mathrm{Al}_{2} \mathrm{O}_{3}$ & 5.1 & 5.1 & 5.3 & 5.3 & 5.3 & 5.6 & 5.6 & 5.9 & 6.2 & 6.2 \\
\hline $\mathrm{MgO}$ & 7.7 & 7.7 & 7.8 & 7.7 & 7.7 & 7.7 & 7.7 & 7.6 & 7.4 & 7.4 \\
\hline $\mathrm{FeO}$ & 2.4 & 2.4 & 2.5 & 2.5 & 2.5 & 2.5 & 2.5 & 2.6 & 2.8 & 2.8 \\
\hline $\mathrm{CaO}$ & 5.6 & 5.6 & 5.6 & 5.6 & 5.5 & 5.5 & 5.5 & 5.4 & 5.4 & 5.4 \\
\hline $\mathrm{Na}_{2} \mathrm{O}$ & 1.5 & 1.5 & 1.5 & 1.5 & 1.5 & 1.5 & 1.5 & 1.6 & 1.7 & 1.7 \\
\hline $\mathrm{K}_{2} \mathrm{O}$ & 0.5 & 0.5 & 0.5 & 0.5 & 0.5 & 0.5 & 0.5 & 0.5 & 0.5 & 0.5 \\
\hline$N$ & 143 & 143 & 140 & 142 & 145 & 152 & 154 & 157 & 178 & 179 \\
\hline
\end{tabular}

\footnotetext{
${ }^{\mathrm{a}} N$ denotes number of synthetic compositions in each $V_{p}$ bin.
} 
Table A.5. Mean and Standard Deviation of Major Element Oxides as a Function of $V_{p}$ for a Normal Continental Geotherm $\left(q_{s}=56 \mathrm{~mW} \mathrm{~m}^{-2}\right)$ With $P_{e q} \geq 12 \mathrm{kbar}^{\mathrm{a}}$

\begin{tabular}{|c|c|c|c|c|c|c|c|c|c|c|}
\hline Depth (km) & 5 & 10 & 15 & 20 & 25 & 30 & 35 & 40 & 45 & 50 \\
\hline $\mathrm{T}\left({ }^{\circ} \mathrm{C}\right)$ & 91 & 155 & 211 & 263 & 311 & 359 & 405 & 451 & 496 & 541 \\
\hline P (kbar) & 1.6 & 3.2 & 4.9 & 6.5 & 8.1 & 9.7 & 11.3 & 12.9 & 14.6 & 16.2 \\
\hline \multicolumn{11}{|c|}{$V_{p}=6.4 \mathrm{~km} / \mathrm{s}$} \\
\hline $\begin{array}{l}\text { Mean } \\
\mathrm{SiO}_{2}\end{array}$ & 70.4 & 70.6 & 70.6 & 71.0 & 71.4 & 72.1 & 73.7 & 74.4 & 74.8 & 74.6 \\
\hline $\mathrm{Al}_{2} \mathrm{O}_{3}$ & 10.9 & 11.1 & 11.1 & 10.8 & 10.3 & 10.0 & 8.8 & 8.2 & 8.2 & 8.4 \\
\hline $\mathrm{MgO}$ & 3.7 & 3.5 & 3.5 & 3.4 & 3.4 & 3.2 & 2.9 & 2.9 & 2.8 & 2.7 \\
\hline $\mathrm{FeO}$ & 6.6 & 6.3 & 6.3 & 6.2 & 6.5 & 6.3 & 6.7 & 6.5 & 6.3 & 6.3 \\
\hline $\mathrm{CaO}$ & 2.7 & 2.7 & 2.7 & 2.7 & 2.5 & 2.5 & 2.3 & 2.4 & 2.4 & 2.3 \\
\hline $\mathrm{Na}_{2} \mathrm{O}$ & 3.0 & 3.0 & 3.0 & 3.0 & 2.9 & 2.9 & 2.6 & 2.5 & 2.5 & 2.6 \\
\hline $\mathrm{K}_{2} \mathrm{O}$ & 2.8 & 2.8 & 2.8 & 2.9 & 2.9 & 3.0 & 3.0 & 3.1 & 3.1 & 3.2 \\
\hline \multicolumn{11}{|l|}{ Std. Dev. } \\
\hline $\mathrm{SiO}_{2}$ & 9.1 & 9.3 & 9.3 & 9.3 & 9.2 & 9.0 & 8.8 & 8.7 & 8.4 & 8.6 \\
\hline $\mathrm{Al}_{2} \mathrm{O}_{3}$ & 8.6 & 8.5 & 8.5 & 8.4 & 8.2 & 8.0 & 7.9 & 7.8 & 7.7 & 7.9 \\
\hline $\mathrm{MgO}$ & 2.5 & 2.5 & 2.5 & 2.3 & 2.2 & 2.1 & 2.0 & 2.0 & 1.9 & 1.8 \\
\hline $\mathrm{FeO}$ & 5.3 & 5.2 & 5.2 & 5.3 & 5.6 & 5.4 & 5.5 & 5.4 & 5.4 & 5.4 \\
\hline $\mathrm{CaO}$ & 1.9 & 1.9 & 1.9 & 1.8 & 1.6 & 1.6 & 1.6 & 1.6 & 1.6 & 1.5 \\
\hline $\mathrm{Na}_{2} \mathrm{O}$ & 2.1 & 2.2 & 2.2 & 2.1 & 2.1 & 2.0 & 2.0 & 2.0 & 2.0 & 2.0 \\
\hline $\mathrm{K}_{2} \mathrm{O}$ & 1.1 & 1.1 & 1.1 & 1.2 & 1.2 & 1.2 & 1.2 & 1.3 & 1.3 & 1.3 \\
\hline$N$ & 63 & 62 & 62 & 57 & 58 & 66 & 72 & 69 & 68 & 64 \\
\hline \multirow{2}{*}{\multicolumn{11}{|c|}{$V_{p}=6.5 \mathrm{~km} / \mathrm{s}$}} \\
\hline Mean & & & & & & & & & & \\
\hline $\mathrm{SiO}_{2}$ & 64.5 & 64.8 & 65.6 & 66.1 & 67.1 & 68.6 & 69.3 & 69.4 & 70.0 & 70.7 \\
\hline $\mathrm{Al}_{2} \mathrm{O}_{3}$ & 14.9 & 14.7 & 14.0 & 13.7 & 12.9 & 11.8 & 11.5 & 11.4 & 11.0 & 10.7 \\
\hline $\mathrm{MgO}$ & 4.5 & 4.5 & 4.4 & 4.3 & 4.4 & 4.3 & 4.2 & 4.1 & 4.1 & 3.9 \\
\hline $\mathrm{FeO}$ & 6.8 & 6.9 & 7.0 & 7.0 & 6.8 & 6.9 & 6.5 & 6.5 & 6.6 & 6.4 \\
\hline $\mathrm{CaO}$ & 2.9 & 2.8 & 2.9 & 2.8 & 2.8 & 2.8 & 2.7 & 2.7 & 2.6 & 2.6 \\
\hline $\mathrm{Na}_{2} \mathrm{O}$ & 3.8 & 3.8 & 3.6 & 3.6 & 3.4 & 3.1 & 3.1 & 3.1 & 3.0 & 2.9 \\
\hline $\mathrm{K}_{2} \mathrm{O}$ & 2.6 & 2.5 & 2.5 & 2.6 & 2.6 & 2.6 & 2.8 & 2.8 & 2.8 & 2.8 \\
\hline
\end{tabular}

Std. Dev.

$\mathrm{Al}_{2} \mathrm{O}_{3}$

$\mathrm{MgO}$

$\mathrm{FeO}$

$\mathrm{CaO}$

$\mathrm{Na}_{2} \mathrm{O}$

$\mathrm{K}_{2} \mathrm{O}$

8.5

\section{5}

\section{8}

$8.9 \quad 9.3$

$\begin{array}{ll}8.9 & 9.3 \\ 8.5 & 8.9\end{array}$

\section{7}

$8.6 \quad 8.6$

$\begin{array}{ll}2.8 & 2.7\end{array}$

2.7

2.7

5.2

2.1

2.2

2.6

\section{1}

$\begin{array}{ll}5.1 & 5.2 \\ 2.2 & 2.1\end{array}$

2.2

2.2

N

1.0

2.2

$$
1.9
$$

2.3

\section{0}

8.4

2.7

5.3

2.0

2.2

9.0
8.6
2.7
5.2
1.9
2.1
1.1

9.1

8.7

2.7

5.2

1.9
2.1

1.1

$77 \quad 74$

77

74

73

$$
V_{p}=6.6 \mathrm{~km} / \mathrm{s}
$$

Mean

$\mathrm{SiO}_{2}$

$\mathrm{Al}_{2} \mathrm{O}_{3}$

$\mathrm{MgO}$

$\mathrm{FeO}$

$\mathrm{CaO}$

$\mathrm{Na}_{2} \mathrm{O}$

$\mathrm{K}_{2} \mathrm{O}$

$\begin{array}{cc}62.5 & 62.4 \\ 15.7 & 15.5 \\ 5.4 & 5.4 \\ 6.6 & 6.9 \\ 3.8 & 3.7 \\ 3.8 & 3.8 \\ 2.3 & 2.3\end{array}$

\section{5}

$62.9 \quad 63.0$

15.5

15.2

15.3

5.5

6.8

5.6

6.9

$$
3.3
$$

3.8

3.8

5.1

\section{1}

3.4
3.8

62.8
15.5
5.1
7.0
3.4
3.9
2.4

62.7
15.6
5.0
7.0
3.2
3.9
2.5

62.7

16.0

62.8

$\begin{array}{ll}4.8 & 4.8\end{array}$

6.9

3.1

4.1

2.5

2.4

\section{0}

$\mathrm{SiO}_{2}$

$\mathrm{MgO}$

3.5

3.5

3.5

10.3

10.3

$9.4 \quad 9.4$

10.1

10.2

3.5

3.2

3.2

9.2 
Table A.5. (continued)

\begin{tabular}{lcccccccccc}
\hline Depth $(\mathrm{km})$ & 5 & 10 & 15 & 20 & 25 & 30 & 35 & 40 & 45 & 50 \\
\hline $\mathrm{T}\left({ }^{\circ} \mathrm{C}\right)$ & 91 & 155 & 211 & 263 & 311 & 359 & 405 & 451 & 496 & 541 \\
$\mathrm{P}(\mathrm{kbar})$ & 1.6 & 3.2 & 4.9 & 6.5 & 8.1 & 9.7 & 11.3 & 12.9 & 14.6 & 16.2 \\
\hline $\mathrm{CaO}$ & 2.7 & 2.7 & 2.5 & 2.5 & 2.5 & 2.5 & 2.4 & 2.4 & 2.2 & 2.2 \\
$\mathrm{Na}_{2} \mathrm{O}$ & 2.2 & 2.3 & 2.3 & 2.3 & 2.4 & 2.4 & 2.3 & 2.3 & 2.3 & 2.3 \\
$\mathrm{~K}_{2} \mathrm{O}$ & 1.0 & 0.9 & 0.9 & 0.9 & 0.9 & 0.9 & 1.0 & 1.0 & 1.0 & 1.0 \\
$N$ & 90 & 95 & 85 & 88 & 83 & 82 & 84 & 84 & 83 & 82
\end{tabular}

\begin{tabular}{|c|c|c|c|c|c|c|c|c|c|c|}
\hline \multicolumn{11}{|c|}{$V_{p}=6.7 \mathrm{~km} / \mathrm{s}$} \\
\hline Mean & & & & & & & & & & \\
\hline $\mathrm{SiO}_{2}$ & 60.2 & 60.0 & 60.1 & 60.1 & 60.2 & 59.9 & 60.1 & 60.3 & 60.4 & 61.1 \\
\hline $\mathrm{Al}_{2} \mathrm{O}_{3}$ & 16.0 & 16.1 & 16.1 & 16.3 & 16.4 & 16.9 & 16.7 & 16.9 & 17.0 & 16.6 \\
\hline $\mathrm{MgO}$ & 5.9 & 5.9 & 5.7 & 5.7 & 5.5 & 5.3 & 5.3 & 5.2 & 5.2 & 5.2 \\
\hline $\mathrm{FeO}$ & 8.1 & 8.1 & 8.1 & 7.9 & 7.8 & 7.6 & 7.7 & 7.5 & 7.3 & 7.2 \\
\hline $\mathrm{CaO}$ & 4.4 & 4.3 & 4.4 & 4.4 & 4.3 & 4.4 & 4.2 & 4.1 & 3.9 & 3.7 \\
\hline $\mathrm{Na}_{2} \mathrm{O}$ & 3.6 & 3.7 & 3.7 & 3.7 & 3.8 & 3.9 & 3.9 & 4.0 & 4.0 & 4.0 \\
\hline $\mathrm{K}_{2} \mathrm{O}$ & 1.8 & 1.9 & 1.9 & 1.9 & 2.0 & 2.0 & 2.1 & 2.1 & 2.1 & 2.2 \\
\hline \multicolumn{11}{|c|}{ Std. Dev. } \\
\hline $\mathrm{SiO}_{2}$ & 9.7 & 9.7 & 9.7 & 9.8 & 9.5 & 9.8 & 9.9 & 10.0 & 10.1 & 10.1 \\
\hline $\mathrm{Al}_{2} \mathrm{O}_{3}$ & 8.2 & 8.2 & 8.2 & 8.3 & 8.0 & 8.3 & 8.5 & 8.3 & 8.5 & 8.7 \\
\hline $\mathrm{MgO}$ & 3.9 & 3.9 & 3.8 & 3.8 & 3.7 & 3.6 & 3.6 & 3.5 & 3.5 & 3.5 \\
\hline $\mathrm{FeO}$ & 5.6 & 5.6 & 5.6 & 5.6 & 5.6 & 5.5 & 5.6 & 5.6 & 5.4 & 5.3 \\
\hline $\mathrm{CaO}$ & 2.9 & 2.8 & 2.8 & 2.8 & 2.9 & 2.9 & 2.8 & 2.8 & 2.7 & 2.6 \\
\hline $\mathrm{Na}_{2} \mathrm{O}$ & 2.2 & 2.2 & 2.2 & 2.2 & 2.1 & 2.2 & 2.3 & 2.2 & 2.2 & 2.2 \\
\hline $\mathrm{K}_{2} \mathrm{O}$ & 1.0 & 1.0 & 1.0 & 1.0 & 1.0 & 1.0 & 1.0 & 1.0 & 1.0 & 1.0 \\
\hline
\end{tabular}

$\begin{array}{lllllllllll}N & 106 & 104 & 103 & 104 & 106 & 104 & 106 & 106 & 101 & 103\end{array}$

\begin{tabular}{|c|c|c|c|c|c|c|c|c|c|c|}
\hline \multicolumn{11}{|c|}{$\mathrm{km} / \mathrm{s}$} \\
\hline $\begin{array}{l}\text { Mean } \\
\mathrm{SiO}_{2}\end{array}$ & 57.4 & 57.6 & 57.9 & 58.1 & 58.2 & 58.3 & 58.3 & 58.8 & 58.9 & 58.5 \\
\hline $\mathrm{Al}_{2} \mathrm{O}_{3}$ & 17.6 & 17.4 & 17.4 & 17.3 & 17.3 & 17.2 & 17.3 & 16.9 & 16.7 & 17.0 \\
\hline $\mathrm{MgO}$ & 6.5 & 6.5 & 6.2 & 6.1 & 6.3 & 6.3 & 6.3 & 6.3 & 6.4 & 6.2 \\
\hline $\mathrm{FeO}$ & 8.1 & 8.1 & 8.0 & 8.0 & 7.7 & 7.7 & 7.7 & 7.9 & 8.0 & 8.3 \\
\hline $\mathrm{CaO}$ & 4.8 & 4.9 & 5.0 & 5.0 & 4.9 & 4.9 & 4.7 & 4.6 & 4.4 & 4.2 \\
\hline $\mathrm{Na}_{2} \mathrm{O}$ & 3.9 & 3.9 & 3.8 & 3.8 & 3.8 & 3.8 & 3.9 & 3.8 & 3.8 & 3.9 \\
\hline $\mathrm{K}_{2} \mathrm{O}$ & 1.7 & 1.7 & 1.7 & 1.7 & 1.8 & 1.8 & 1.8 & 1.8 & 1.8 & 1.8 \\
\hline \multicolumn{11}{|c|}{ Std. Dev. } \\
\hline $\mathrm{SiO}_{2}$ & 9.8 & 9.4 & 9.5 & 9.5 & 9.5 & 9.7 & 9.8 & 10.2 & 10.1 & 10.3 \\
\hline $\mathrm{Al}_{2} \mathrm{O}_{3}$ & 8.3 & 8.1 & 8.1 & 8.1 & 8.1 & 8.2 & 8.2 & 8.4 & 8.4 & 8.5 \\
\hline $\mathrm{MgO}$ & 4.1 & 4.1 & 4.0 & 4.0 & 4.1 & 4.0 & 4.0 & 4.0 & 4.0 & 3.9 \\
\hline $\mathrm{FeO}$ & 5.4 & 5.4 & 5.4 & 5.5 & 5.5 & 5.4 & 5.5 & 5.7 & 5.6 & 5.5 \\
\hline $\mathrm{CaO}$ & 3.3 & 3.3 & 3.3 & 3.3 & 3.3 & 3.3 & 3.2 & 3.1 & 2.9 & 2.7 \\
\hline $\mathrm{Na}_{2} \mathrm{O}$ & 2.3 & 2.3 & 2.3 & 2.3 & 2.2 & 2.3 & 2.2 & 2.3 & 2.3 & 2.3 \\
\hline $\mathrm{K}_{2} \mathrm{O}$ & 1.1 & 1.1 & 1.1 & 1.1 & 1.1 & 1.1 & 1.1 & 1.1 & 1.1 & 1.0 \\
\hline$N$ & 132 & 132 & 138 & 138 & 141 & 139 & 136 & 129 & 129 & 125 \\
\hline \multicolumn{11}{|c|}{$V_{p}=6.9 \mathrm{~km} / \mathrm{s}$} \\
\hline \multicolumn{11}{|l|}{ Mean } \\
\hline $\mathrm{SiO}_{2}$ & 57.6 & 57.8 & 57.8 & 57.8 & 57.6 & 57.7 & 57.4 & 57.5 & 57.5 & 57.2 \\
\hline $\mathrm{Al}_{2} \mathrm{O}_{3}$ & 16.8 & 16.7 & 16.7 & 16.7 & 16.8 & 16.8 & 17.2 & 17.1 & 17.1 & 17.4 \\
\hline $\mathrm{MgO}$ & 7.6 & 7.6 & 7.7 & 7.6 & 7.7 & 7.5 & 7.3 & 7.3 & 7.2 & 7.2 \\
\hline $\mathrm{FeO}$ & 6.8 & 6.8 & 6.8 & 7.0 & 7.1 & 7.3 & 7.3 & 7.7 & 7.7 & 7.8 \\
\hline $\mathrm{CaO}$ & 5.9 & 6.0 & 5.8 & 5.7 & 5.5 & 5.5 & 5.3 & 5.0 & 5.0 & 4.9 \\
\hline $\mathrm{Na}_{2} \mathrm{O}$ & 3.5 & 3.5 & 3.5 & 3.5 & 3.6 & 3.6 & 3.7 & 3.7 & 3.8 & 3.9 \\
\hline $\mathrm{K}_{2} \mathrm{O}$ & 1.7 & 1.7 & 1.7 & 1.7 & 1.7 & 1.7 & 1.7 & 1.7 & 1.7 & 1.7 \\
\hline
\end{tabular}


Table A.5. (continued)

\begin{tabular}{|c|c|c|c|c|c|c|c|c|c|c|}
\hline Depth (km) & 5 & 10 & 15 & 20 & 25 & 30 & 35 & 40 & 45 & 50 \\
\hline $\mathrm{T}\left({ }^{\circ} \mathrm{C}\right)$ & 91 & 155 & 211 & 263 & 311 & 359 & 405 & 451 & 496 & 541 \\
\hline P (kbar) & 1.6 & 3.2 & 4.9 & 6.5 & 8.1 & 9.7 & 11.3 & 12.9 & 14.6 & 16.2 \\
\hline \multicolumn{11}{|l|}{ Std. Dev. } \\
\hline $\mathrm{SiO}_{2}$ & 9.0 & 9.0 & 9.1 & 9.1 & 9.5 & 9.5 & 9.7 & 9.9 & 9.8 & 9.8 \\
\hline $\mathrm{Al}_{2} \mathrm{O}_{3}$ & 8.1 & 8.1 & 8.1 & 8.1 & 8.3 & 8.3 & 8.3 & 8.4 & 8.3 & 8.3 \\
\hline $\mathrm{MgO}$ & 4.7 & 4.7 & 4.7 & 4.7 & 4.6 & 4.6 & 4.5 & 4.5 & 4.5 & 4.4 \\
\hline $\mathrm{FeO}$ & 4.9 & 4.9 & 4.9 & 4.9 & 5.0 & 5.1 & 5.0 & 5.0 & 5.3 & 5.3 \\
\hline $\mathrm{CaO}$ & 3.9 & 3.9 & 3.9 & 3.9 & 3.8 & 3.7 & 3.6 & 3.4 & 3.4 & 3.3 \\
\hline $\mathrm{Na}_{2} \mathrm{O}$ & 2.3 & 2.3 & 2.3 & 2.3 & 2.3 & 2.3 & 2.3 & 2.3 & 2.3 & 2.3 \\
\hline $\mathrm{K}_{2} \mathrm{O}$ & 1.0 & 1.0 & 1.0 & 1.0 & 1.0 & 1.0 & 1.0 & 1.0 & 1.1 & 1.0 \\
\hline$N$ & 151 & 153 & 153 & 153 & 152 & 150 & 144 & 139 & 141 & 139 \\
\hline \multicolumn{11}{|c|}{$V_{p}=7.0 \mathrm{~km} / \mathrm{s}$} \\
\hline \multicolumn{11}{|l|}{ Mean } \\
\hline $\mathrm{SiO}_{2}$ & 57.9 & 57.9 & 57.9 & 57.8 & 57.9 & 57.8 & 58.1 & 58.2 & 58.2 & 58.4 \\
\hline $\mathrm{Al}_{2} \mathrm{O}_{3}$ & 15.3 & 15.3 & 15.3 & 15.4 & 15.4 & 15.5 & 15.4 & 15.5 & 15.6 & 15.7 \\
\hline $\mathrm{MgO}$ & 8.9 & 9.0 & 9.0 & 9.0 & 8.9 & 9.0 & 8.8 & 8.4 & 8.3 & 8.2 \\
\hline $\mathrm{FeO}$ & 6.8 & 6.9 & 6.9 & 7.0 & 7.0 & 7.0 & 7.0 & 6.9 & 6.8 & 6.6 \\
\hline $\mathrm{CaO}$ & 6.5 & 6.5 & 6.4 & 6.2 & 6.2 & 6.1 & 6.2 & 6.2 & 6.3 & 6.3 \\
\hline $\mathrm{Na}_{2} \mathrm{O}$ & 3.0 & 3.0 & 3.0 & 3.0 & 3.0 & 3.1 & 3.1 & 3.1 & 3.1 & 3.2 \\
\hline $\mathrm{K}_{2} \mathrm{O}$ & 1.5 & 1.5 & 1.5 & 1.5 & 1.5 & 1.6 & 1.6 & 1.6 & 1.6 & 1.7 \\
\hline \multicolumn{11}{|l|}{ Std. Dev. } \\
\hline $\mathrm{SiO}_{2}$ & 8.5 & 8.6 & 8.6 & 8.6 & 8.6 & 8.5 & 8.7 & 8.5 & 8.5 & 8.5 \\
\hline $\mathrm{Al}_{2} \mathrm{O}_{3}$ & 7.2 & 7.2 & 7.2 & 7.3 & 7.2 & 7.2 & 7.3 & 7.3 & 7.4 & 7.4 \\
\hline $\mathrm{MgO}$ & 5.3 & 5.3 & 5.4 & 5.4 & 5.4 & 5.3 & 5.3 & 5.2 & 5.3 & 5.2 \\
\hline $\mathrm{FeO}$ & 4.8 & 4.8 & 4.8 & 4.8 & 4.7 & 4.8 & 4.6 & 4.7 & 4.7 & 4.7 \\
\hline $\mathrm{CaO}$ & 4.4 & 4.3 & 4.3 & 4.1 & 4.1 & 4.0 & 4.0 & 4.0 & 3.9 & 3.9 \\
\hline $\mathrm{Na}_{2} \mathrm{O}$ & 2.2 & 2.2 & 2.2 & 2.2 & 2.1 & 2.1 & 2.1 & 2.1 & 2.1 & 2.1 \\
\hline $\mathrm{K}_{2} \mathrm{O}$ & 0.9 & 0.9 & 0.9 & 0.9 & 0.9 & 0.9 & 0.9 & 0.9 & 0.9 & 1.0 \\
\hline$N$ & 142 & 139 & 143 & 141 & 143 & 143 & 143 & 145 & 146 & 152 \\
\hline \multicolumn{11}{|c|}{$V_{p}=7.1 \mathrm{~km} / \mathrm{s}$} \\
\hline Mean & & & & & & & & & & \\
\hline $\mathrm{SiO}_{2}$ & 56.1 & 56.1 & 56.1 & 56.2 & 56.6 & 56.8 & 57.1 & 57.3 & 57.3 & 57.6 \\
\hline $\mathrm{Al}_{2} \mathrm{O}_{3}$ & 15.8 & 15.7 & 15.7 & 15.8 & 15.5 & 15.4 & 15.2 & 15.3 & 15.3 & 15.2 \\
\hline $\mathrm{MgO}$ & 9.7 & 9.8 & 9.7 & 9.6 & 9.6 & 9.6 & 9.7 & 9.3 & 9.2 & 9.0 \\
\hline $\mathrm{FeO}$ & 7.7 & 7.7 & 7.6 & 7.6 & 7.4 & 7.3 & 7.3 & 7.1 & 7.2 & 7.1 \\
\hline $\mathrm{CaO}$ & 6.3 & 6.3 & 6.3 & 6.4 & 6.6 & 6.5 & 6.4 & 6.6 & 6.7 & 6.8 \\
\hline $\mathrm{Na}_{2} \mathrm{O}$ & 3.1 & 3.1 & 3.1 & 3.1 & 3.0 & 3.0 & 2.9 & 2.9 & 2.9 & 2.9 \\
\hline $\mathrm{K}_{2} \mathrm{O}$ & 1.4 & 1.4 & 1.4 & 1.4 & 1.4 & 1.4 & 1.4 & 1.4 & 1.4 & 1.4 \\
\hline \multicolumn{11}{|l|}{ Std. Dev. } \\
\hline $\mathrm{SiO}_{2}$ & 8.9 & 8.9 & 8.9 & 8.9 & 8.7 & 8.7 & 8.7 & 8.7 & 8.9 & 8.8 \\
\hline $\mathrm{Al}_{2} \mathrm{O}_{3}$ & 7.5 & 7.5 & 7.5 & 7.5 & 7.3 & 7.3 & 7.3 & 7.4 & 7.5 & 7.5 \\
\hline $\mathrm{MgO}$ & 5.6 & 5.7 & 5.7 & 5.6 & 5.6 & 5.6 & 5.5 & 5.4 & 5.4 & 5.3 \\
\hline $\mathrm{FeO}$ & 5.2 & 5.2 & 5.2 & 5.2 & 5.0 & 5.0 & 5.0 & 4.9 & 4.8 & 4.8 \\
\hline $\mathrm{CaO}$ & 4.5 & 4.5 & 4.5 & 4.5 & 4.6 & 4.6 & 4.5 & 4.5 & 4.4 & 4.4 \\
\hline $\mathrm{Na}_{2} \mathrm{O}$ & 2.3 & 2.2 & 2.2 & 2.2 & 2.2 & 2.2 & 2.2 & 2.2 & 2.2 & 2.2 \\
\hline $\mathrm{K}_{2} \mathrm{O}$ & 1.0 & 1.0 & 1.0 & 1.0 & 0.9 & 0.9 & 0.9 & 0.9 & 0.9 & 0.9 \\
\hline$N$ & 128 & 129 & 131 & 130 & 133 & 139 & 140 & 146 & 148 & 155 \\
\hline \multicolumn{11}{|c|}{$V_{p}=7.2 \mathrm{~km} / \mathrm{s}$} \\
\hline Mean & & & & & & & & & & \\
\hline $\mathrm{SiO}_{2}$ & 54.6 & 54.7 & 54.6 & 54.8 & 54.8 & 54.9 & 55.2 & 55.2 & 55.1 & 55.4 \\
\hline $\mathrm{Al}_{2} \mathrm{O}_{3}$ & 16.3 & 16.2 & 16.2 & 16.1 & 16.1 & 16.0 & 15.9 & 16.0 & 16.1 & 16.0 \\
\hline $\mathrm{MgO}$ & 10.1 & 10.1 & 10.1 & 10.1 & 10.2 & 10.1 & 10.1 & 10.1 & 9.9 & 9.9 \\
\hline
\end{tabular}


Table A.5. (continued)

\begin{tabular}{|c|c|c|c|c|c|c|c|c|c|c|}
\hline Depth $(\mathrm{km})$ & 5 & 10 & 15 & 20 & 25 & 30 & 35 & 40 & 45 & 50 \\
\hline $\mathrm{T}\left({ }^{\circ} \mathrm{C}\right)$ & 91 & 155 & 211 & 263 & 311 & 359 & 405 & 451 & 496 & 541 \\
\hline P (kbar) & 1.6 & 3.2 & 4.9 & 6.5 & 8.1 & 9.7 & 11.3 & 12.9 & 14.6 & 16.2 \\
\hline $\mathrm{FeO}$ & 8.0 & 8.0 & 8.0 & 7.9 & 7.9 & 7.9 & 7.9 & 7.9 & 7.9 & 7.8 \\
\hline $\mathrm{CaO}$ & 6.5 & 6.6 & 6.6 & 6.7 & 6.6 & 6.7 & 6.6 & 6.5 & 6.6 & 6.5 \\
\hline $\mathrm{Na}_{2} \mathrm{O}$ & 3.2 & 3.2 & 3.2 & 3.1 & 3.2 & 3.1 & 3.1 & 3.1 & 3.1 & 3.1 \\
\hline $\mathrm{K}_{2} \mathrm{O}$ & 1.3 & 1.3 & 1.3 & 1.3 & 1.3 & 1.3 & 1.3 & 1.3 & 1.3 & 1.3 \\
\hline \multicolumn{11}{|l|}{ Std. Dev. } \\
\hline $\mathrm{SiO}_{2}$ & 8.6 & 8.6 & 8.6 & 8.6 & 8.6 & 8.7 & 8.7 & 8.6 & 8.7 & 8.8 \\
\hline $\mathrm{Al}_{2} \mathrm{O}_{3}$ & 7.8 & 7.7 & 7.8 & 7.6 & 7.6 & 7.6 & 7.5 & 7.5 & 7.5 & 7.6 \\
\hline $\mathrm{MgO}$ & 5.5 & 5.5 & 5.5 & 5.5 & 5.5 & 5.5 & 5.5 & 5.5 & 5.6 & 5.5 \\
\hline $\mathrm{FeO}$ & 4.9 & 5.0 & 5.0 & 5.0 & 5.0 & 5.0 & 5.1 & 5.1 & 5.2 & 5.2 \\
\hline $\mathrm{CaO}$ & 4.2 & 4.2 & 4.2 & 4.4 & 4.4 & 4.5 & 4.4 & 4.4 & 4.5 & 4.4 \\
\hline $\mathrm{Na}_{2} \mathrm{O}$ & 2.1 & 2.1 & 2.2 & 2.1 & 2.1 & 2.1 & 2.1 & 2.1 & 2.1 & 2.1 \\
\hline $\mathrm{K}_{2} \mathrm{O}$ & 1.0 & 1.0 & 1.0 & 1.0 & 1.0 & 1.0 & 1.0 & 0.9 & 0.9 & 0.9 \\
\hline$N$ & 136 & 138 & 137 & 138 & 139 & 138 & 145 & 151 & 147 & 146 \\
\hline \multicolumn{11}{|c|}{$V_{p}=7.3 \mathrm{~km} / \mathrm{s}$} \\
\hline Mean & & & & & & & & & & \\
\hline $\mathrm{SiO}_{2}$ & 52.7 & 52.7 & 52.8 & 53.0 & 53.0 & 52.9 & 53.3 & 53.5 & 53.5 & 53.4 \\
\hline $\mathrm{Al}_{2} \mathrm{O}_{3}$ & 17.9 & 17.9 & 17.8 & 17.5 & 17.6 & 17.6 & 17.3 & 16.9 & 16.8 & 16.9 \\
\hline $\mathrm{MgO}$ & 9.9 & 9.8 & 9.8 & 10.0 & 9.9 & 10.0 & 10.1 & 10.4 & 10.6 & 10.6 \\
\hline $\mathrm{FeO}$ & 7.4 & 7.5 & 7.5 & 7.5 & 7.6 & 7.6 & 7.6 & 7.7 & 7.8 & 7.8 \\
\hline $\mathrm{CaO}$ & 7.4 & 7.4 & 7.5 & 7.2 & 7.2 & 7.2 & 7.2 & 7.0 & 6.8 & 6.8 \\
\hline $\mathrm{Na}_{2} \mathrm{O}$ & 3.4 & 3.4 & 3.4 & 3.4 & 3.4 & 3.4 & 3.3 & 3.3 & 3.3 & 3.3 \\
\hline $\mathrm{K}_{2} \mathrm{O}$ & 1.3 & 1.3 & 1.2 & 1.3 & 1.3 & 1.3 & 1.3 & 1.3 & 1.3 & 1.3 \\
\hline \multicolumn{11}{|l|}{ Std. Dev. } \\
\hline $\mathrm{SiO}_{2}$ & 8.5 & 8.5 & 8.5 & 8.6 & 8.6 & 8.8 & 8.8 & 8.8 & 8.8 & 8.8 \\
\hline $\mathrm{Al}_{2} \mathrm{O}_{3}$ & 7.4 & 7.4 & 7.4 & 7.4 & 7.5 & 7.6 & 7.5 & 7.5 & 7.6 & 7.5 \\
\hline $\mathrm{MgO}$ & 6.0 & 5.8 & 5.8 & 5.9 & 6.0 & 5.9 & 5.9 & 5.9 & 5.9 & 5.9 \\
\hline $\mathrm{FeO}$ & 4.7 & 4.7 & 4.7 & 4.7 & 4.8 & 4.7 & 4.7 & 4.8 & 4.8 & 4.8 \\
\hline $\mathrm{CaO}$ & 4.7 & 4.7 & 4.7 & 4.5 & 4.4 & 4.4 & 4.4 & 4.4 & 4.3 & 4.3 \\
\hline $\mathrm{Na}_{2} \mathrm{O}$ & 2.1 & 2.1 & 2.1 & 2.1 & 2.1 & 2.1 & 2.1 & 2.1 & 2.0 & 2.0 \\
\hline $\mathrm{K}_{2} \mathrm{O}$ & 1.0 & 0.9 & 0.9 & 0.9 & 1.0 & 1.0 & 0.9 & 0.9 & 0.9 & 0.9 \\
\hline$N$ & 131 & 130 & 129 & 130 & 130 & 131 & 137 & 137 & 136 & 137 \\
\hline \multicolumn{11}{|c|}{$V_{p}=7.4 \mathrm{~km} / \mathrm{s}$} \\
\hline Mean & & & & & & & & & & \\
\hline $\mathrm{SiO}_{2}$ & 51.5 & 51.4 & 51.6 & 51.8 & 51.8 & 51.9 & 51.7 & 51.7 & 52.0 & 52.0 \\
\hline $\mathrm{Al}_{2} \mathrm{O}_{3}$ & 18.4 & 18.6 & 18.5 & 18.4 & 18.4 & 18.3 & 18.5 & 18.5 & 18.3 & 18.2 \\
\hline $\mathrm{MgO}$ & 10.7 & 10.7 & 10.6 & 10.5 & 10.6 & 10.4 & 10.4 & 10.1 & 10.1 & 10.2 \\
\hline $\mathrm{FeO}$ & 7.1 & 7.0 & 6.9 & 6.9 & 6.9 & 7.0 & 7.1 & 7.1 & 7.2 & 7.2 \\
\hline $\mathrm{CaO}$ & 7.7 & 7.7 & 7.8 & 7.8 & 7.8 & 7.8 & 7.8 & 7.9 & 7.8 & 7.9 \\
\hline $\mathrm{Na}_{2} \mathrm{O}$ & 3.4 & 3.5 & 3.4 & 3.4 & 3.4 & 3.4 & 3.5 & 3.5 & 3.4 & 3.4 \\
\hline $\mathrm{K}_{2} \mathrm{O}$ & 1.1 & 1.2 & 1.2 & 1.2 & 1.2 & 1.2 & 1.2 & 1.2 & 1.2 & 1.2 \\
\hline \multicolumn{11}{|l|}{ Std. Dev. } \\
\hline $\mathrm{SiO}_{2}$ & 8.2 & 8.2 & 8.2 & 8.1 & 8.2 & 8.1 & 8.3 & 8.3 & 8.4 & 8.4 \\
\hline $\mathrm{Al}_{2} \mathrm{O}_{3}$ & 7.5 & 7.4 & 7.4 & 7.5 & 7.5 & 7.4 & 7.5 & 7.5 & 7.5 & 7.5 \\
\hline $\mathrm{MgO}$ & 6.9 & 7.0 & 6.9 & 6.8 & 6.8 & 6.7 & 6.7 & 6.5 & 6.4 & 6.4 \\
\hline $\mathrm{FeO}$ & 4.7 & 4.7 & 4.7 & 4.7 & 4.7 & 4.7 & 4.8 & 4.8 & 4.7 & 4.7 \\
\hline $\mathrm{CaO}$ & 5.3 & 5.3 & 5.3 & 5.3 & 5.2 & 5.2 & 5.2 & 5.2 & 5.2 & 5.2 \\
\hline $\mathrm{Na}_{2} \mathrm{O}$ & 2.1 & 2.1 & 2.1 & 2.1 & 2.1 & 2.1 & 2.1 & 2.1 & 2.2 & 2.1 \\
\hline $\mathrm{K}_{2} \mathrm{O}$ & 0.9 & 0.9 & 0.9 & 0.9 & 0.9 & 0.9 & 0.9 & 0.9 & 0.9 & 0.9 \\
\hline$N$ & 104 & 105 & 107 & 111 & 111 & 113 & 112 & 114 & 119 & 120 \\
\hline
\end{tabular}


Table A.5. (continued)

\begin{tabular}{|c|c|c|c|c|c|c|c|c|c|c|}
\hline Depth (km) & 5 & 10 & 15 & 20 & 25 & 30 & 35 & 40 & 45 & 50 \\
\hline $\mathrm{T}\left({ }^{\circ} \mathrm{C}\right)$ & 91 & 155 & 211 & 263 & 311 & 359 & 405 & 451 & 496 & 541 \\
\hline P (kbar) & 1.6 & 3.2 & 4.9 & 6.5 & 8.1 & 9.7 & 11.3 & 12.9 & 14.6 & 16.2 \\
\hline \multicolumn{11}{|c|}{$V_{p}=7.5 \mathrm{~km} / \mathrm{s}$} \\
\hline $\begin{array}{l}\text { Mean } \\
\mathrm{SiO}_{2}\end{array}$ & 51.5 & 51.6 & 51.4 & 51.4 & 51.6 & 51.7 & 51.6 & 51.8 & 52.0 & 52.0 \\
\hline $\mathrm{Al}_{2} \mathrm{O}_{3}$ & 17.4 & 17.5 & 17.5 & 17.7 & 17.7 & 17.5 & 17.8 & 17.8 & 17.8 & 17.8 \\
\hline $\mathrm{MgO}$ & 11.8 & 11.8 & 11.8 & 11.6 & 11.4 & 11.1 & 11.0 & 10.8 & 10.6 & 10.5 \\
\hline $\mathrm{FeO}$ & 7.2 & 7.1 & 7.2 & 7.1 & 7.0 & 7.2 & 7.1 & 6.9 & 6.9 & 7.0 \\
\hline $\mathrm{CaO}$ & 8.0 & 8.0 & 7.8 & 8.1 & 8.2 & 8.3 & 8.4 & 8.4 & 8.5 & 8.6 \\
\hline $\mathrm{Na}_{2} \mathrm{O}$ & 3.1 & 3.1 & 3.1 & 3.1 & 3.1 & 3.1 & 3.1 & 3.1 & 3.1 & 3.1 \\
\hline $\mathrm{K}_{2} \mathrm{O}$ & 1.0 & 1.0 & 1.0 & 1.0 & 1.0 & 1.0 & 1.0 & 1.0 & 1.1 & 1.0 \\
\hline \multicolumn{11}{|l|}{ Std. Dev. } \\
\hline $\mathrm{SiO}_{2}$ & 8.0 & 8.0 & 7.9 & 7.8 & 7.8 & 7.7 & 7.6 & 7.5 & 7.5 & 7.6 \\
\hline $\mathrm{Al}_{2} \mathrm{O}_{3}$ & 7.3 & 7.3 & 7.4 & 7.3 & 7.3 & 7.2 & 7.1 & 7.1 & 7.0 & 7.0 \\
\hline $\mathrm{MgO}$ & 7.0 & 7.0 & 7.0 & 7.0 & 7.0 & 7.0 & 7.1 & 7.0 & 7.0 & 6.9 \\
\hline $\mathrm{FeO}$ & 5.0 & 5.0 & 4.9 & 4.9 & 4.9 & 5.0 & 5.0 & 5.0 & 5.0 & 4.9 \\
\hline $\mathrm{CaO}$ & 5.7 & 5.7 & 5.8 & 5.9 & 5.9 & 5.9 & 6.0 & 5.9 & 5.9 & 5.9 \\
\hline $\mathrm{Na}_{2} \mathrm{O}$ & 2.1 & 2.0 & 2.1 & 2.1 & 2.1 & 2.1 & 2.0 & 2.0 & 2.0 & 2.0 \\
\hline $\mathrm{K}_{2} \mathrm{O}$ & 0.8 & 0.8 & 0.9 & 0.8 & 0.9 & 0.9 & 0.8 & 0.9 & 0.9 & 0.9 \\
\hline$N$ & 90 & 91 & 92 & 95 & 97 & 96 & 97 & 101 & 105 & 103 \\
\hline \multicolumn{11}{|c|}{$V_{p}=7.6 \mathrm{~km} / \mathrm{s}$} \\
\hline Mean & & & & & & & & & & \\
\hline $\mathrm{SiO}_{2}$ & 50.7 & 50.4 & 49.9 & 49.9 & 49.5 & 49.6 & 49.8 & 49.3 & 48.7 & 48.8 \\
\hline $\mathrm{Al}_{2} \mathrm{O}_{3}$ & 18.0 & 18.0 & 18.1 & 17.9 & 18.3 & 18.1 & 18.1 & 18.5 & 18.7 & 18.7 \\
\hline $\mathrm{MgO}$ & 11.7 & 12.0 & 12.1 & 12.3 & 12.1 & 12.3 & 12.4 & 12.6 & 12.9 & 12.7 \\
\hline $\mathrm{FeO}$ & 6.6 & 6.7 & 7.1 & 7.3 & 7.2 & 7.2 & 6.9 & 6.8 & 6.9 & 6.9 \\
\hline $\mathrm{CaO}$ & 9.0 & 8.9 & 8.6 & 8.6 & 8.8 & 8.7 & 8.9 & 8.9 & 8.7 & 8.8 \\
\hline $\mathrm{Na}_{2} \mathrm{O}$ & 3.1 & 3.1 & 3.2 & 3.1 & 3.2 & 3.1 & 3.1 & 3.2 & 3.2 & 3.2 \\
\hline $\mathrm{K}_{2} \mathrm{O}$ & 1.0 & 1.0 & 1.0 & 0.9 & 0.9 & 0.9 & 0.9 & 0.9 & 0.8 & 0.8 \\
\hline \multicolumn{11}{|l|}{ Std. Dev. } \\
\hline $\mathrm{SiO}_{2}$ & 7.9 & 8.0 & 8.3 & 8.2 & 8.8 & 8.9 & 8.8 & 9.1 & 9.7 & 9.6 \\
\hline $\mathrm{Al}_{2} \mathrm{O}_{3}$ & 6.9 & 6.8 & 7.4 & 7.5 & 7.8 & 7.7 & 7.6 & 7.8 & 7.9 & 7.9 \\
\hline $\mathrm{MgO}$ & 7.0 & 7.1 & 7.0 & 7.1 & 7.1 & 7.1 & 7.1 & 7.1 & 6.9 & 6.9 \\
\hline $\mathrm{FeO}$ & 4.8 & 4.8 & 4.9 & 4.8 & 4.8 & 4.8 & 4.5 & 4.4 & 4.4 & 4.4 \\
\hline $\mathrm{CaO}$ & 6.0 & 6.0 & 5.9 & 5.8 & 5.9 & 5.9 & 5.8 & 5.9 & 5.6 & 5.6 \\
\hline $\mathrm{Na}_{2} \mathrm{O}$ & 2.1 & 2.1 & 2.2 & 2.1 & 2.2 & 2.2 & 2.1 & 2.1 & 2.1 & 2.1 \\
\hline $\mathrm{K}_{2} \mathrm{O}$ & 1.0 & 1.0 & 1.0 & 0.9 & 0.9 & 0.9 & 0.9 & 0.9 & 0.8 & 0.8 \\
\hline$N$ & 72 & 74 & 77 & 77 & 78 & 79 & 80 & 84 & 87 & 91 \\
\hline
\end{tabular}

${ }^{\mathrm{a}} N$ denotes number of synthetic compositions in each $V_{p}$ bin. 
Detrick, Peter Clift, and Clark Burchfiel provided helpful comments on an earlier version of this manuscript. This research was supported by National Science Foundation Grants OCE9819666, EAR-9910899, and EAR-0087706 (P.B. Kelemen). Contribution 10780 of Woods Hole Oceanographic Institution.

\section{References}

Austrheim, H., The influence of fluid and deformation on metamorphism of the deep crust and consequences for geodynamics of collision zones, in When Continents Collide: Geodynamics and Geochemsitry of Ultrahigh-Pressure Rocks, edited by B. Hacker and J. Liou, pp. 297-323, Kluwer Acad., Norwell, Mass., 1998.

Babeyko, A., and V. Zharkov, Martian crust: A modeling approach, Phys. Earth Planet. Inter, 117, 421-435, 2000.

Babeyko, A., S. Sobolev, E. Sinelnikov, Y. Smirnov, and N. Derevschikova, Calculations of elastic properties in lower part of the Kola borehole from bulk chemical compositions of core samples, Surv. Geophys., 15, 545-573, 1994.

Baker, M., and E. Stolper, Determining the composition of high-pressure mantle melts using diamond aggregates, Geochim. Cosmochim. Acta, 58, 2811-2827, 1994.

Baker, M., M. Hirschmann, M. Ghiorso, and E. Stolper, Compositions of near-solidus peridotite melts from experiments and thermodynamic calculations, Nature, 375, 308-311, 1995.

Bass, J., Elasticity of minerals, glasses, and melts, in A Handbook of Physical Constants: Mineral Physics and Crystallography, AGU Ref. Shelf Ser., vol. 2, edited by T. Ahrens, pp. 45-63, AGU, Washington, D.C., 1995.

Bernstein, S., High-pressure fractionation in rift-related basaltic magmatism: Faeroe plateau basalts, Geology, 22, 815818, 1994.

Berryman, J., Mixture theories for rock properties, in A Handbook of Physical Constants: Rock Physics and Phase Relations, AGU Ref. Shelf Ser., vol. 3, edited by T. Ahrens, pp. 205-228, AGU, Washington, D.C., 1995.

Birch, F., Intepretation of the seismic structure of the crust in light of experimental studies of wave velocities in rocks, in Contributions in Geophysics in Honor of Beno Gutenberg, edited by H. Benioff, pp. 158-170, Pergamon, New York, 1958.

Birch, F., The velocity of compressional waves in rocks to 10 kilobars, 1, J. Geophys. Res., 65, 1083-1102, 1960.

Birch, F., The velocity of compressional waves in rocks to 10 kilobars, 2, J. Geophys. Res., 66, 2199-2224, 1961.

Brandle, J., and G. Nagy, The state of the 5th Version of the IGBA: Igneous Petrological Data Base, Comput. Geosci., 21, 425-432, 1995.

Browning, P., The petrology, geochemistry, and structure of the plutonic rocks of the Oman ophiolite, Ph.D. thesis, Open Univ., Milton Keynes, England, 1982.

Burke, M., and D. Fountain, Seismic properties of rocks from an exposure of extended continental crust-new laboratory measurements from the Ivrea Zone, Tectonophys., 182, 119-146, 1990.
Burns, L., The Border Ranges ultramafic and mafic complex: Plutonic core of an intraoceanic island arc, Ph.D. dissertation, Stanford Univ., Stanford, Calif., 1983.

Carlson, R., The abundance of ultramafic rocks in Atlantic Ocean crust, Geophys. J. Int., 144, 37-48, 2001.

Carlson, R., and J. Miller, A new assessment of the abundance of serpentinites in the oceanic crust, Geophys. Res. Lett., 24, 457-460, 1997.

Casey, J., Comparison of major- and trace-element geochemistry of abyssal peridotites and mafic plutonic rocks with basalts from the MARK Region of the Mid-Atlantic Ridge, Proc. Ocean Drill. Program Sci. Res., 153, 181-241, 1997.

Chayes, F., IGBADAT: A world data base for igneous petrology, Episodes, 8, 245-251, 1985.

Christensen, N., Compressional wave velocities in metamorphic rocks at pressures to 10 kilobars, J. Geophys. Res., 70, 6147-6164, 1965.

Christensen, N., Ophiolites, seismic velocities and oceanic crustal structure, Tectonophys., 47, 131-157, 1978.

Christensen, N., Compressional wave velocities in rocks at high temperature and pressures, critical thermal gradients, and crustal low-velocity zones, J. Geophys. Res., 84, 6849-6857, 1979.

Christensen, N., Reflectivity and seismic properties of the deep continental crust, J. Geophys. Res., 94, 17,79317,804, 1989.

Christensen, N., and W. Mooney, Seismic velocity structure and composition of the continental crust: A global view, J. Geophys. Res., 100, 9761-9788, 1995.

Christensen, N., and M. Salisbury, Structure and constitution of the lower oceanic crust, Rev. Geophys., 13, 57-86, 1975.

Christensen, N., and J. Smewing, Geology and seismic structure of the northern section of the Oman ophiolite, J. Geophys. Res., 86, 2545-2555, 1981.

Christensen, N., and D. Szymanski, Origin of reflections from the Brevard fault zone, J. Geophys. Res., 93, 1087-1102, 1988.

Connolly, J., Multivariable phase diagrams: an algorithm based on generalized thermodynamics, Am. J. Sci., 290, 666-718, 1990.

DeBari, S., and N. Sleep, High-Mg, low-Al bulk composition of the Talkeetna island arc, Alaska: Implications for primary magmas and the nature of arc crust, Geol. Soc. Am. Bull., 103, 37-47, 1991.

Dick, H., et al., A long in situ section of the lower ocean crust: results of ODP Leg 176 drilling at the Southwest Indian Ridge, Earth Planet. Sci. Lett., 179, 31-51, 2000.

Dietz, R., Alpine serpentinites as oceanic rind fragments, Geol. Soc. Am. Bull., 74, 947-952, 1963.

Dupuy, C., A. Leyreloup, and J. Vernieres, The lower continental crust of the Massif Central (Bournac, France) with special references to REE, $U$ and Th composition, evolution, and heatflow production, Phys. Chem. Earth, 11, 401-415, 1979.

Fliedner, M., and S. Klemperer, Structure of an island-arc: Wide-angle seismic studies in the eastern Aleutian Islands, Alaska, J. Geophys. Res., 104, 10,667-10,694, 1999. 
Fliedner, M., and S. Klemperer, Crustal structure transition from oceanic arc to continental arc, eastern Aleutian Islands and Alaskan Peninsula, Earth Planet. Sci. Lett., 179, 567579, 2000.

Fountain, D., and N. Christensen, Composition of the continental crust and upper mantle: A review, Mem. Geol. Soc. Am., 172, 711-742, 1989.

Fountain, D., M. Salisbury, and J. Percival, Seismic structure of the continental crust based on rock velocity measurements from the Kapuskasing uplift, J. Geophys. Res., 95, 11671186, 1990.

Gao, S., B.-R. Zhang, Z.-M. Jin, H. Kern, T.-C. Luo, and Z.-D. Zhao, How mafic is the lower continental crust, Earth Planet. Sci. Lett., 161, 101-117, 1998.

Gao, S., H. Kern, Y.-S. Liu, S.-Y. Jin, T. Popp, Z.-M. Jin, J.-L. Feng, M. Sun, and Z.-B. Zhao, Measured and calculated seismic velocities and densities for granulites from xenolith occurrences and adjacent exposed lower crustal sequences: A comparative study from the North China craton, J. Geophys. Res., 105, 18,965-18,976, 2000.

Gregory, R., and H. Taylor, An oxygen isotope profile in a section of Cretaceous oceanic crust, Samail ophiolite, Oman: Evidence for $\delta^{18} \mathrm{O}$ buffering of the oceans by deep ( $\left.\geq 5 \mathrm{~km}\right)$ seawater-hydrothermal circulation at mid-ocean ridges, J. Geophys. Res., 86, 2737-2755, 1981.

Hacker, B., E. Gnos, L. Ratschbacher, M. Grove, M. McWilliams, S. Sobolev, J. Wan, and W. Zhenhan, Hot and dry deep crustal xenoliths from Tibet, Science, 287, 24632466, 2000.

Hashin, Z., and S. Shtrikman, A variational approach to the elastic behavior of multiphase materials, J. Mech. Phys. Solids, 11, 127-140, 1963.

Hekinian, R., D. Bideau, J. Francheteau, J. Cheminee, R. Armijo, P. Lonsdale, and N. Blum, Petrology of the East Pacific Rise crust and upper mantle exposed in Hess Deep (Eastern Equatorial Pacific), J. Geophys. Res., 98, 80698094, 1993.

Hess, H., History of ocean basins, in Petrologic Studies, edited by A. Engel, H. James, and B. Leonard, pp. 599-620, Geol. Soc. of Am., Boulder, Colo., 1962.

Hess, H., Mid-ocean ridges and tectonics of the seafloor, in Submarine Geology and Geophysics, edited by W. Whittard and R. Bradshaw, pp. 317-333, Colston Research Symposium, Butterworths, London, 1965.

Hirose, K., and I. Kushiro, Partial melting of dry peridotites at high pressures: Determination of compositions of melts segregated from peridotite using aggregates of diamond, Earth Planet. Sci. Lett., 114, 477-489, 1993.

Hirschmann, M., M. Baker, and E. Stopler, The effect of alkalis on the silica content of mantle-derived melts, Geochim. Cosmochim. Acta, 62, 883-902, 1998.

Holbrook, W., and P. Kelemen, Large igneous province on the US Atlantic margin and implications for magmatism during continental breakup, Nature, 364, 433-436, 1993.

Holbrook, W., W. Mooney, and N. Christensen, The seismic velocity structure of the deep continental crust, in Continental Lower Crust, edited by D. Fountain, R. Arculus, and R. Kay, pp. 1-43, Elsevier Sci., New York, 1992.
Holbrook, W., G. Purdy, R. Sheridan, L. Glover, M. Talwani, J. Ewing, and D. Hutchinson, Seismic structure of the U.S. mid-Atlantic continental margin, J. Geophys. Res., 99, 17,871-17,891, 1994.

Holbrook, W., D. Lizarralde, S. McGeary, N. Bangs, and J. Diebold, Structure and composition of the Aleutian island arc and implications for continental crustal growth, Geology, 27, 31-34, 1999.

Holbrook, W., et al., Mantle thermal structure and active upwelling during continental breakup in the North Atlantic, Earth Planet. Sci. Lett., 190, 251-266, 2001.

Holland, T., and R. Powell, An internally consistent thermodynamic data set for phases of petrological interest, $\mathrm{J}$. Metamorph. Geol., 16, 309-343, 1998.

Huenges, E., J. Lauterjung, C. Bücker, E. Lippman, and H. Kern, Seismic velocity, density, thermal conductivity and heat production of cores from the KTB pilot hole, Geophys. Res. Lett., 24, 345-348, 1997.

Hyndman, D., Petrology of Igneous and Metamorphic Rocks, McGraw-Hill, New York, 1985.

Iturrino, G., N. Christensen, S. Kirby, and M. Salisbury, Seismic velocities and elastic properties of oceanic gabbroic rocks from hole 735b, Proc. Ocean Drill. Program Sci. Res., 118, 227-244, 1991.

Iturrino, G., D. Miller, and N. Christensen, Velocity behavior of lower crustal and upper mantle rocks from a fast-spreading ridge at Hess Deep, Proc. Ocean Drill. Program Sci. Res., 147, 417-440, 1996.

Jackson, I., The petrophysical basis for the interpretation of seismological models of the continental lithosphere, Spec. Pub. Geol. Soc. Aust., 17, 81-114, 1991.

Jackson, I., R. Rudnick, S. O'Reilly, and C. Bezant, Measured and calculated elastic wave velocities for xenoliths from the lower crust and upper mantle, Tectonophys., 173, 207-210, 1990.

Kay, R., and S. Kay, The nature of the lower continental crust: Inferences from geophysics, surface geology, and crustal xenoliths, Rev. Geophys., 19, 271-297, 1981.

Kelemen, P., and W. Holbrook, Origin of thick, high-velocity igneous crust along the U.S. East Coast margin, J. Geophys. Res., 100, 10,077-10,094, 1995.

Kern, H., P- and S-wave velocities in crustal and mantle rocks under the simultaneous action of high confining pressure and high temperature and the effect of rock microstructure, in High-Pressure Researches in Geoscience, edited by W. Schreyer, pp. 15-45, Schweizerbart'sche, 1982.

Kern, H., and A. Richter, Temperature derivatives of compressional and shear wave velocities in crustal and mantle rocks at 6 kbar confining pressure, J. Geophys., 49, 47-56, 1981.

Kern, H., and V. Schenk, Elastic wave velocities in rocks from a lower crustal section in southern Calabria (Italy), Phys. Earth Planet. Inter., 40, 147-160, 1985.

Kern, H., and V. Schenk, A model of velocity structure beneath Calabria, southern Italy, based on laboratory data, Earth Planet. Sci. Lett., 87, 325-337, 1988.

Kern, H., and J. Tubia, Pressure and temperature dependence of P- and S-wave velocities, seismic anisotropy and density 
of sheared rocks from the Sierra Alpujata massif (Ronda peridotites, southern Spain), Earth Planet. Sci. Lett., 119, 191-205, 1993.

Kern, H., S. Gao, and Q.-S. Liu, Seismic properties and densities of middle and lower crustal rocks exposed along the North China Geoscience Transect, Earth Planet. Sci. Lett., 139, 439-455, 1996.

Kinzler, R., Melting of mantle peridotite at pressures approaching the spinel to garnet transition: Application to mid-ocean ridge basalt petrogenesis, J. Geophys. Res., 102, 853-874, 1997.

Kinzler, R., and T. Grove, Primary magmas of mid-ocean ridge basalts, 2, Applications, J. Geophys. Res., 97, 6907-6926, 1992.

Kinzler, R., and T. Grove, Corrections and further discussion of the primary magmas of midocean ridge basalts, 1 and 2, J. Geophys. Res., 98, 22,339-22,347, 1993.

Kogiso, T., K. Hirose, and E. Takahashi, Melting experiments on homogeneous mixtures of peridotite and basalt: Application to the genesis of ocean island basalts, Earth Planet. Sci. Lett., 162, 45-61, 1998.

Korenaga, J., W. Holbrook, G. Kent, P. Kelemen, R. Detrick, H.-C. Larsen, J. Hopper, and T. Dahl-Jensen, Crustal structure of the southeast Greenland margin from joint refraction and reflection seismic tomography, J. Geophys. Res., 105, 21,591-21,614, 2000.

Korenaga, J., P. B. Kelemen, and W. S. Holbrook, Methods for resolving the origin of large igneous provinces from crustal seismology, J. Geophys. Res., 107(B9), 2178, doi:10.1029/ 2001JB001030, 2002.

LASE Study Group, Deep structure of the U.S. East Coast passive margin from large aperture seismic experiments (LASE), Mar. Petrol. Geol., 3, 234-242, 1986.

Manghnani, M., R. Ramananantoadndro, and J. Clark, Compressional and shear wave velocities in granulite facies rocks and eclogites to 10 kbar, J. Geophys. Res., 79, 5427-5446, 1974.

McKenzie, D., and M. Bickle, The volume and composition of melt generated by extension of the lithosphere, J. Petrol., 29, 625-679, 1988.

McLennan, S., and S. Taylor, Heat flow and the chemical composition of the continental crust, J. Geol., 104, 377396, 1996.

Miller, D., and N. Christensen, Seismic signature and geochemistry of an island arc: A multidisciplinary study of the Kohistan accreted terrane, northern Pakistan, J. Geophys. Res., 99, 11,623-11,642, 1994.

Miller, D., and N. Christensen, Seismic velocities of the lower crustal and upper mantle rocks from the slow spreading Mid-Atlantic Ridge, south of the Kane transform zone (MARK), Proc. Ocean Drill. Program Sci. Results, 153, 437-454, 1997.

Miller, D., G. Iturrino, and N. Christensen, Geochemical and petrological constraints on velocity behavior of lower crustal and upper mantle rocks from the fast-spreading ridge at Hess Deep, Proc. Ocean Drill. Program Sci. Res., 147, 477-490, 1996.

Morozov, I., S. Smithson, L. Hollister, and J. Diebold, Wideangle seismic imaging across accreted terranes, southeastern
Alaska and western British Columbia, Tectonophys., 299, 281-296, 1998.

Mutter, J., W. Buck, and C. Zehnder, A model for the formation of thick basaltic sequences during the initiation of spreading, J. Geophys. Res., 93, 1031-1048, 1988.

Pakiser, L., and R. Robinson, Composition and evolution of the continental crust as suggested by seismic observations, Tectonophys., 3, 547-557, 1966.

Pallister, J., Parent magmas of the Semail ophiolite, Oman, in Ophiolites and Oceanic Lithosphere, edited by I. Gass, S. Lippard, and A. Shelton, vol. 13, pp. 63-70, Geol. Soc. Spec. Pub., Boulder, Colo., 1984.

Pederson, R., J. Malpas, and T. Falloon, Petrology and geochemistry of gabbroic and related rocks from Site 894, Hess Deep, Proc. Ocean Drill. Program Sci. Res., 147, 3-19, 1996.

Pollack, H., and D. Chapman, On the regional variation of heat flow, geotherms, and lithospheric thickness, Tectonophys., 38, 279-296, 1977.

Raitt, R., The crustal rocks, in The Sea, edited by M. Hill, pp. 85-102, Wiley-Interscience, New York, 1963.

Reid, I., Crustal structure of a nonvolcanic rifted margin east of Newfoundland, J. Geophys. Res., 99, 15,16115,180, 1994.

Robinson, P., R. Von Herzen, and the Shipboard Scientific Party, Proc. Ocean Drill. Program Init., 118, 1989.

Rudnick, R., and D. Fountain, Nature and composition of the continental crust: A lower crustal perspective, Rev. Geophys., 33, 267-309, 1995.

Rudnick, R., and I. Jackson, Measured and calculated elastic wave speeds in partially equilibrated mafic granulite xenoliths: Implications for the properties of an underplated lower continental crust, J. Geophys. Res., 100, 10,211-10,218, 1995.

Rudnick, R., and T. Presper, Geochemistry of intermediate- to high-pressure granulites, in Granulites and Crustal Evolution, edited by D. Vielzeuf and P. Vidal, pp. 523-550, Kluwer Acad., Norwell, Mass., 1990.

Salisbury, M., and N. Christensen, The seismic velocity structure of a traverse through the Bay of Islands ophiolite complex, Newfoundland, and exposure of oceanic crust and upper mantle, J. Geophys. Res., 83, 805-817, 1984.

Shaw, D., J. Cramer, M. Higgins, and M. Truscott, Composition of the Canadian Precambrian shield and the continental crust of the earth, in The Nature of the Lower Continental Crust, edited by J. Dawson et al., pp. 275-282, Geol. Soc. Spec. Pub., Boulder, Colo., 1986.

Shor, G., H. Menard, and R. Raitt, Structure of the Pacific Basin, in The Sea, edited by A. Maxwell, pp. 3-27, Wiley-Interscience, New York, 1970.

Smithson, S., Modeling continental crust: Structure and chemical constraints, Geophys. Res. Lett., 5, 749-752, 1978.

Sobolev, S., and A. Babeyko, Phase transformations in the lower continental crust and its seismic structure, in Properties and Processes of Earth's Lower Crust, Geophys. Monogr. Ser., vol. 51, edited by R. Mereu, S. Mueller, and D. Fountain, pp. 311-320, AGU, Washington, D.C., 1989. 
Sobolev, S., and A. Babeyko, Modeling of mineralogical composition, density and elastic wave velocities in anhydrous magmatic rocks, Surv. Geophys., 15, 515-544, 1994.

Sobolev, S., H. Zeyen, G. Stoll, F. Werling, R. Altherr, and K. Fuchs, Upper mantle temperatures from teleseismic tomography of French Massif Central including effects of composition, mineral reactions, anharmonicity, anelasticity, and partial melt, Earth Planet. Sci. Lett., 139, 147-163, 1996.

Sobolev, S., H. Zeyen, M. Granet, U. Achauer, C. Bauer, F. Werling, R. Altherr, and K. Fuchs, Upper mantle temperatures and lithosphere-asthenosphere system beneath the French Massif Central constrained by seismic, gravity, petrologic and thermal observations, Tectonophys., 275, 143164, 1997.

Stein, C., and S. Stein, A model for the global variation in oceanic depth and heat flow with lithospheric age, Nature, 359, 123-129, 1992.

Suyehiro, K., et al., Continental crust, crustal underplating, and low-Q upper mantle beneath an oceanic island arc, Science, 272, 390-392, 1996.

Taylor, S., and S. McLennan, The Continental Crust: Its Composition and Evolution, Blackwell, Malden, Mass., 1985.

Tréhu, A., A. Ballard, L. Dorman, J. Gettrust, K. Klitgord, and A. Schreiner, Structure of the lower crust beneath the Car- olina Trough, U.S. Atlantic continental margin, J. Geophys. Res., 94, 10,585-10,600, 1989.

Tucholke, B., J. Austin, and E. Uchupi, Crustal structure and rift-drift evolution of the Newfoundland Basin, in Extensional Tectonics and Stratigraphy of the North Atlantic Margin, edited by A. Tankard and H. Balkwell, AAPG Mem., 46, 247-263, 1989.

Walter, M., Melting of garnet peridotite and the origin of komatiite and depleted lithosphere, J. Petrol., 39, 29-60, 1998.

Watt, J., G. Davies, and R. O'Connell, The elastic properties of composite materials, Rev. Geophys., 14, 541-563, 1976.

Weaver, B., and J. Tarney, Major and trace element composition of the continental lithosphere, Phys. Chem. Earth, 15, 39-68, 1984.

Wedepohl, K., The composition of the continental crust, Geochim. Cosmochim. Acta, 59, 1217-1232, 1995.

White, R., and D. McKenzie, Magmatism at rift zones: The generation of volcanic continental margins and flood basalts, J. Geophys. Res., 94, 7685-7729, 1989.

White, R., D. McKenzie, and R. O’Nions, Oceanic crustal thickness from seismic measurements and rare earth element inversions, J. Geophys. Res., 97, 19,683-19,715, 1992. 